(200)

R 290

no 413

C

UNITED STATES DEPARTMENT OF THE INTERIOR

GEOLOGICAL SURVEY

GEOLOGY OF THE HYDE PARK QUADRANGLE, VERMONT

By

Arden L. Albee

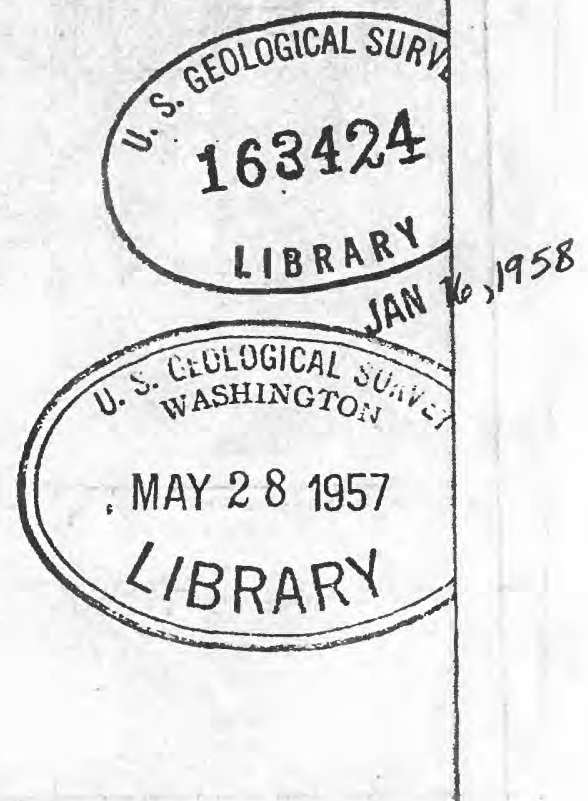

Apr11 1957

$57-1$

U. S. Goolog10al Survey OPEN FIIE RETPRT

This roport is prolluingry and has

not boen edited or revicu to

oonformity with Geologien ourvey

standards or nouremelat.t1r. 


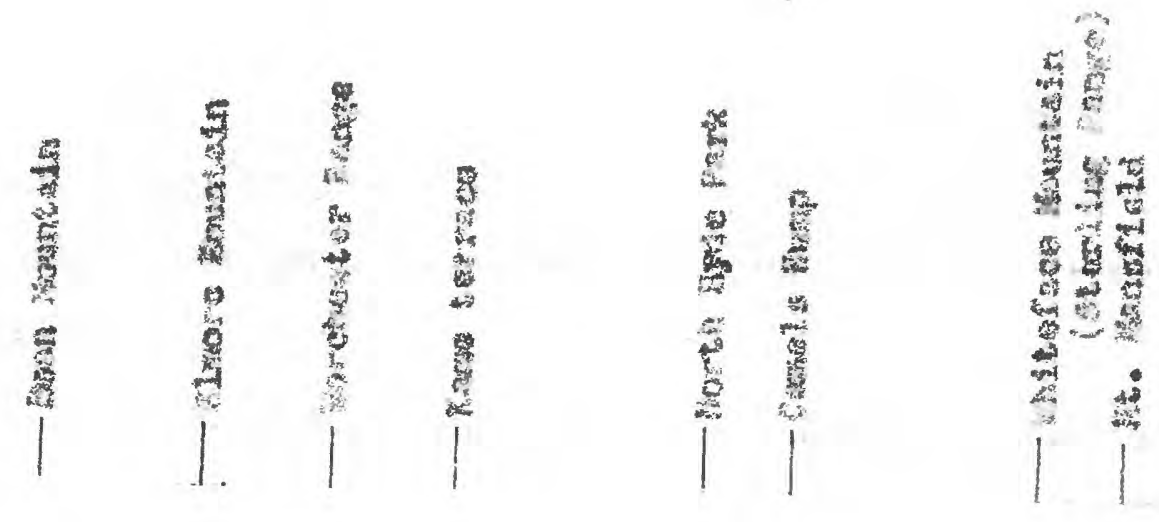

PLATE 5

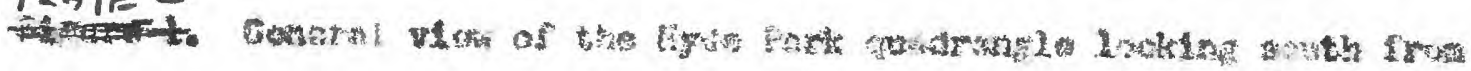

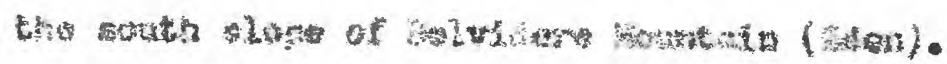


Abstract .......................... pocket

Introduction ........................ 1

Location and culture ................. 1

Topography and drainage ................. 2

Purpose of etudy ................... 3

Hethod of stuxdy ................. 4

Acknowlodgements .................. 6

Provlous work ..................... 7

Reglonal geologle setting............... 9

Stratlgraphy and Lthology ................. 21

Deneral statement ................. 11

Hetarorphosed sedimentary and volcanic rocks . . . 17

Camels hurp group ................ 27

General statment ............ 17

Albite schist and gneiss, graphitic schist,

and quartzite ............ 18

Quarte-sericite-chlorito-agaznetite-alb ite

schist.............. 23

Greenstone ............. 28

BeIvidere Hountain anghibolite ..... 28

Ottauquecher formation ........... 30

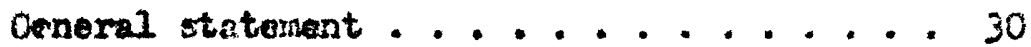


Ottanquechee formation -- Continued.

Distribution ............... 30

Description ............... 31

stom formation ........................ 34

General statement .......... 34

Lower schist ............ 38

Amphibalite and greenstono ....... 40

Tpper achist ............. 42

schlet in the Foot Brook area ...... 44

Unbrella HIII conglomerate......... 45

Koratora formation ............ 49

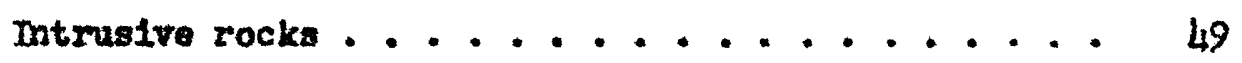

serpentinite, talc-carbonate rock, and steatite. 49

Lamprophyre dikes ........... 50

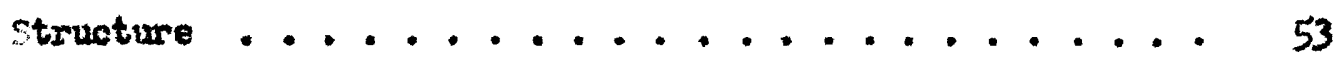

Major structural fantures............. 53

Minor atructural features............. 5

Introduction ............... 54

Character and epatial relations of rinor

structures ............. 59

General statoment .............. 59

$s_{1}$ and $s_{2}$ planar fentures........ 61

$J_{1}$ IInear features .......... 62 
Character and spatial =0lations of minor structures - Continued.

S planar features ........... 63

lin linear features ............. 64

5 planar features . . . . . . . . 65

$L_{3}(?)$ Linear leature and $5(3)$ planar

features................. 66

Jolnts ..................... 67

Botated porphrroblats ........... 67

Fabric ................... 68

Relation of minor structurel festures to major

structural features ........... 69

ortgin of the minor etructures....... 71

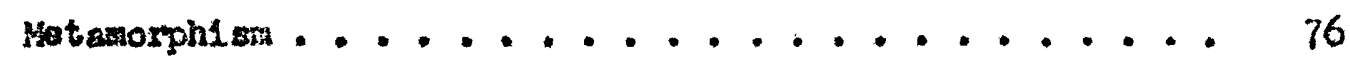

Coneral stateront ................ 76

Mineralogs and petrography of the schiet ..... 76

Petrolors of the ratercous schlst. ....... 83

zones of progressive gistonal matariorphiss . . 83

petrology of the relcaceous sehists of the Hyde

park quadranglo ........... 85

Introduction .......... 85

Plgure 6 ................ 89

Fifur 6 b............... 90 
Petrology of the forceous ochlets of the Hyde Park quadrangle - Continued.

Flgure 6c.............. 91

F1gure 6d...................... 92

Plgure 6e.............. 93!

Tetrograde metamorphlam ........ 93

Prometamorphic nature of the mloacecus sohists ... . 96

Genoral statement ........... 96

Compostion of arglllacecus and arenaceous sedimontary rocks ............. 96

Comparison of the composition of the micaceous

schists to sedimantary rocks ....... 102

Reglonal relations............... 104

General etaterent .............. 104

Stratigraphy of northorn vermont .......... 206

Eestern Vermont sequenco in northern Vermont. . 107

Hestem Vermont sequence in northern Vermont. . 113

North-central Vormont sequence........ 114

IEneous rocks ............ 216

structure ................... 127

Problems of the geology of northern Vermont..... 120

Correlation between the eastern and western verwont

sequences . . . . . . . . . . . . 122 
Page

Minerel secources of the bodrock .............. 227 Tale .................... 127 other elmeral resources of the bedrock ....... 128

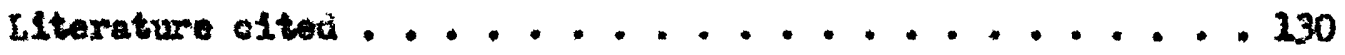

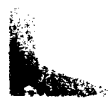


P1gura

1. Indox map ....................... 2

2. Felations of alnor etruotures west of the Foot irook aynoline ..................... 61

3. Relation of bota index of refraction and totrahedrelly coordinated alwainow in chlorite.....

4. Palation of beta index of rafraction and iron-content of ehlar1te....................... 8

5. Constumetion of the triangular diagrom aesd in

Pigure 6. ....................... 88

6. Thase diagrame thowing the rinural apsemblages of quarts and wucorite ahlet............... 88

7. Chemios characteriotic of detrital sediments . . 98

8. Comparison of $\mathrm{Al}_{2} \mathrm{O}_{3}$ ve. $\mathrm{SLO}_{2}$ for wodimnts ard for nlonceous cohists of the Hyde Perk quadrangla .. 103

9. Chesdcal characteriatios of nloncous schiat ram the Hyde Fark quadranglo ............. 104 
Plate

Pollowing $P$ ats

1. Goologie map .................. pooket

2. Tectonic pap ................ Fockot

3. Topographle wap................ Pockat Not

4. Goologie an of morthern vermont and southcentral ouebeo ................ pocket

5. Canoral view of Hods Perk quadrangle ...... Irontiopiece

6. yxponurea of the Camele Bup orop ........ 22

7. Expostre of the Camols Hump group ....... 25

8. Hopowroe of the staw tormation ........ 34

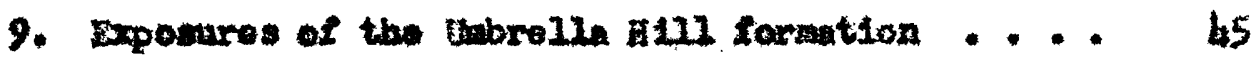

10. Compoxition Iayorims and guarts ogrogation in the camels wum groap ............. 61

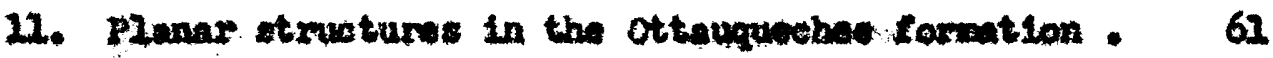

12. cranvage ..................... 61

23. Cleavage .................... 61

14. Ehtetosty in camels gump graip ........ 61

15. Firot and wecend-stage falds .......... 61

16. Flret and eecond-atage falda .......... 61 
Pasto

1. stratigraphic soction ............. 15-16

2. Hodes of the Canelo Hump group .......... 19

3. Kodes of the Cruals inumg group .......... 24

4. Noder of the dtauqueche fermation ....... 32

5. Wedas of the stowe format10a ........... 35

6. Koden of the stowe roration........... 36

7. Kodes of the stowe formation ........... 37

8. Weles of the thore1la w12 formation and the Morotour formation ............. 48

9. Kodas of post-motanorphise dikas ......... 52

10. Calorite arialyous and optical data........ Pochot

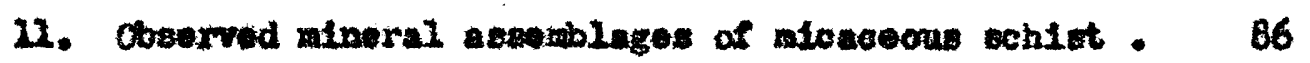

12. optical date on chlorita, blotite, and ehlerttold. 87

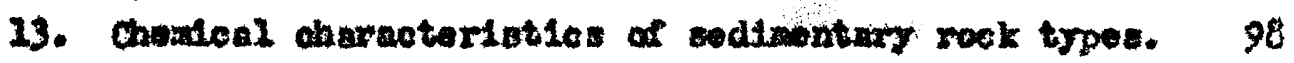

24. Developmant of rock units of eabtern Yermont

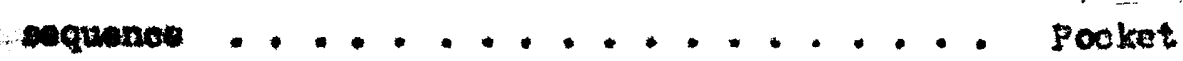

25. correlation of roek undte of eastorn verwont mequence .................. Poeket

16. Corrolation of westora vermant asquence..... Fockot 
-U. S. Geological Survey OPEN FIJE PEPCRT

roport is proliminary ane

sen edited on reviewed foi

ruity with Geological Survey

jards or nomenclature.

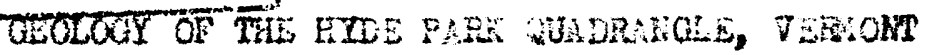

by

Anden Leroy Albee

ABEThaS

The axis of the Green Hountrin anticilnorium trends northnortheast across the northwest corner of the Hydo Park quadranflo. This anticlinorium, which is tho principal structural featuro of the bedrock of Vermont, extends north-northeast from the Massachnsettg-Vernont border the full length of the state and about 50 milles Into Quebec, atol distance of about $210 \mathrm{miles}$.

The bedrock in the Hydo Park quadrangle is predominantiy motamorphosed sedimontary and volcante rock, wich has boen intruded by lamprophyre dikes and by ultramaite rocks. The sequence 1s divided into five formations, its ostimated thickness is about 19,500 feot. No fossils have boen found, but the rocke are tentatively dated as Cambromordorlcian by their position between the Precambrian unconformity and rock of probable Midda ordorictan age.

All the rocks in this area except the 2amphrophyre dikes have been affected by reglonel motanorphl sm. Host of the lyde Paiks quadrangle is in the chlorite sone of metamorpht an. In the higher grade part of the chlorite sone either chloritold or blotite ay occur, depending primarily upon the aluninusi content of the rock. Elotite is rare in the rocks of the Hyie park quadrangle, but chloritoid is

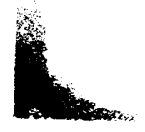


present in the stowe romation. The garmet and krante gones are confined to the stowe formation in the southeastern part of the quadrangle. The sesemblages of the sarnet and kyantte zones have partially or wholly retrograded to essemblages of the chlorite zone. Phase diagram, based on the observed assemblages, are uead to dLcues the mineralogical transformations at successively higher Erados of metanorpht and the retrograde alteration of the higher grade rocks.

A statistical study of the chemical corposition of argillaceous and arenaceous oedinentary rocks forms the basl for determining the protollth (premetanorphic parent rock) of the motamorphle rocks. The waight percent of allica, and the relative molar proportions of

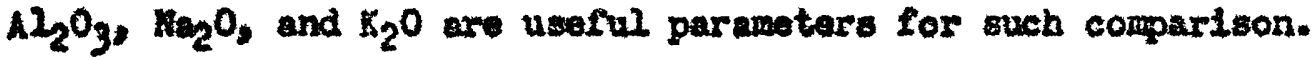
Thase factor were also calculated for tho metamorphic rocks fram estimated modes. The comon protollths of the netamorphic rocks of the Iride Park quadrangl are quartzose sandstone, carbonaceous and nonoarbonaceous shale, and aubgranwacle. Weither grayracke nor arkose were common.

The areen fountais onticlinarlum is the major structure in the area, and the larger folds throughout the quadrangle parallel it. The evidence of major faliti was observed. Finor structure include planar featurea, folde, rotated porphyroblasts, and linear features. Planar features shown an the map and clscussed include bedding, varlous types of schlotosity, and slip cleavege, fracture cloavege, slaty 
clearage, and jointe, though not mappad, are present locally.

Inear features shown on the map include querte rods, fold and crinklo axes, and the intersections of cortain planar features; mineral linotion, streaxing, and eremulation, though not shown on the map, are comon. Within the Hyde park quadrangle two differently orlented sets of folds, each with relsted slp cleavege and schlstosity that inter sect folded follation in lines parallel to respective fold axes, the distingulohed. In many places, particularly noar the axis of the Green Hountain anticlinorium, one sat is auperimposed upon the other. The axes of the earlier eet of folds are parallel to the bedding follation and nearly at right angles to the exes of the Green Hountain anticlinorium. The exes of the later set of folds are abparallel to the exis of the Green Mountaln anticlinoriua. The enrlier folds and related achlatosity are foldod about the north-tronding, nearly horlecntal axes of broad open folds. It is tentatively cargested that the earlier fold are die to shortening or extansion parallel to the major fold axes caused by the forration of plunging folde, salfents, nnd recesses in the Green wountain anticlincolum.

A tale mine is operated northoset of Joinson Villae, and another talc deposit of possiblo comercial value has been discovered southueat of Lowen Hountain. 
SARTODUCTICA

Socation and culture

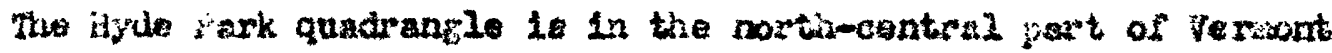

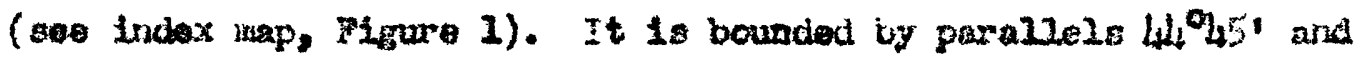

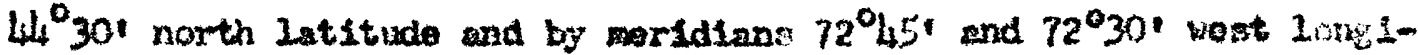
tude, and covers about 222 square alles.

The are is priagrily an agricultural diatrict; luabering, the anufneture of ferest products, and minlng are othor major cocupatlons. Sav ils are in North Ilyde Paxk, Herrioville, and Johnson, and a plyzood 111 is in Horriortlle. A tale ano and mull aro in Jehnson,

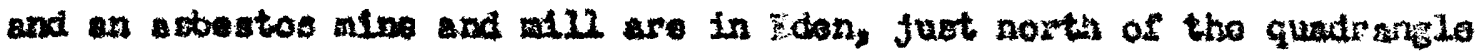
boundary.

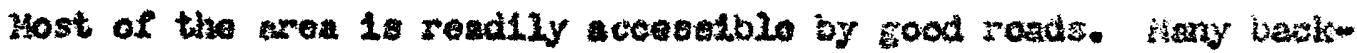
roeds have been acandoned in recent years, but reviad topographic

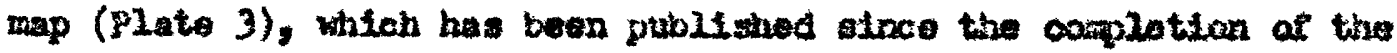

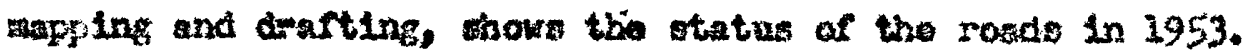
Cultivated land and open pasture wake up about 15 percent of the areas

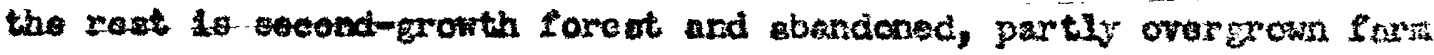
Lande. 


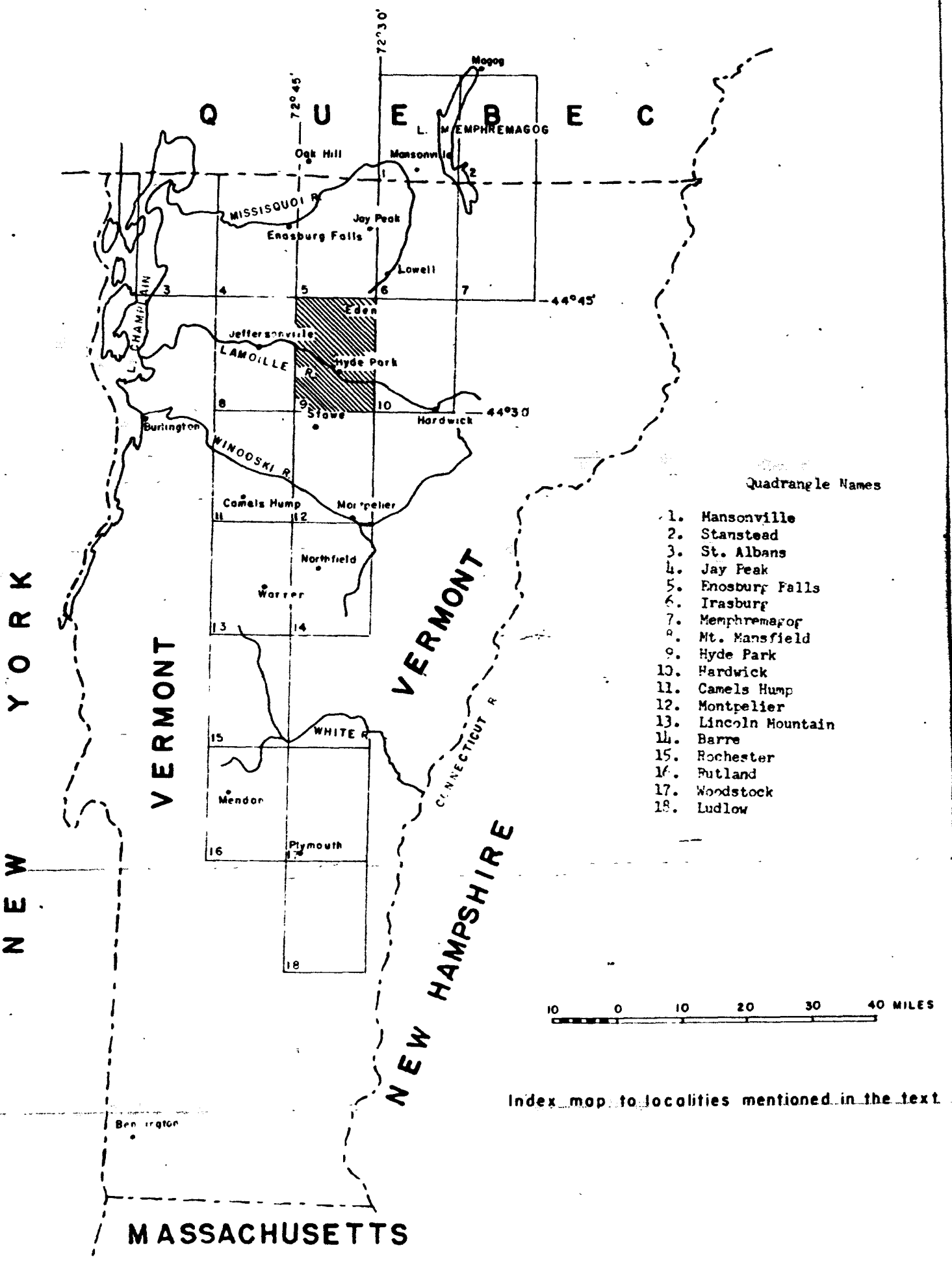




\section{Toporreohy and dralnage}

The Groen Kowntalns on the west alde of the quadrancle havo a

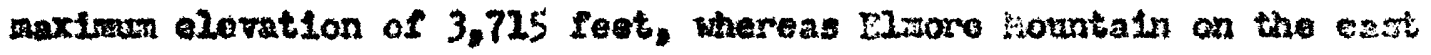
side has en elevtion of 2,608 fest. The lamollle fivor at the rost stae of the quadranglo has an elevat1on of abont 455 foet and 15 the

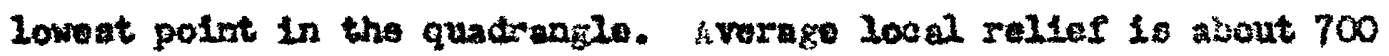
fect, bat local relief my be as wah as 1,800 feet. systens a nortit trending ridges on both the aeet and went oldes coaverge in the northe part of the area, eloetng broud central raliey. In the northrobt ad

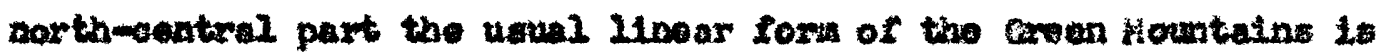

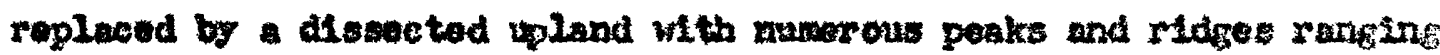
Ixam 2,000 to 2,700 feot in altituda.

The Lanalle fiver Mows northweteriy across the ares, transactIng both the coen foutulns and the eatern pidges.

The topography, whlch has been largety proctuced by preglacial etrea disection, reflect to cow axtent the structural pattern, attitude, and rarlod erosional reslstanoe of the underlying rocks.

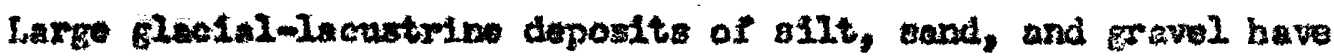
accumulated in the valleys, kata torraces wodlfy the blopes, and

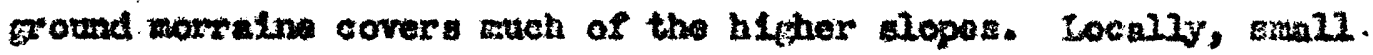

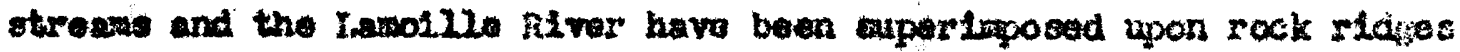
artar cutting through large accumation of glactal depostat in genaral, the glectal depoest have onothad the proglacial land areface

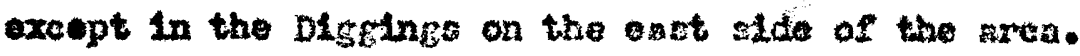




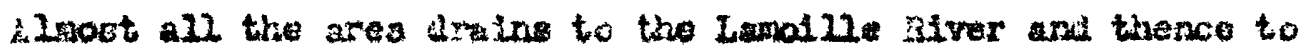

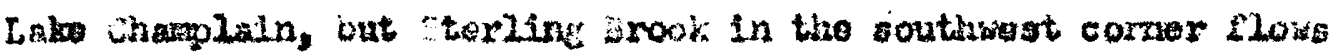

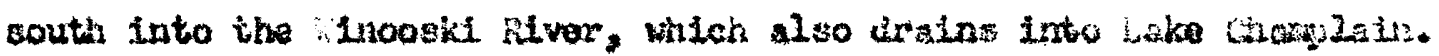

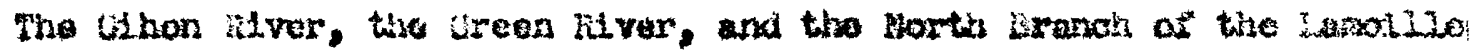

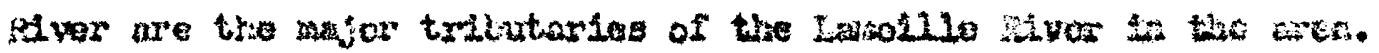

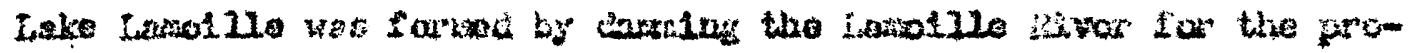

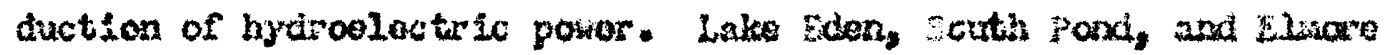

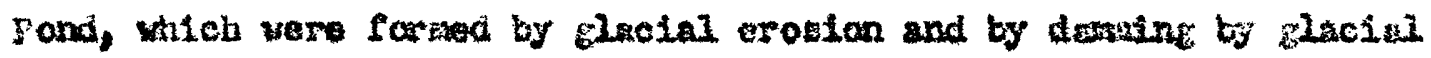
deposite, heve been enlarged by the erection of deme to cantral the

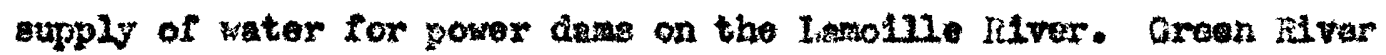
Le serrol- (Plato 3) Is another otorage area whleh was forrad by the orection of a concrete dan, about 60 feat high, on tho gren ritwer.

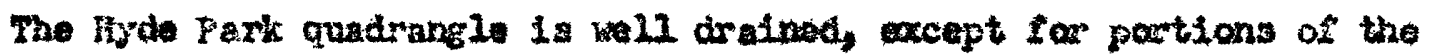

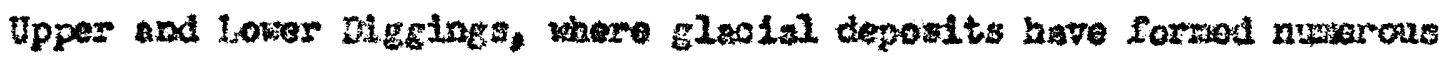

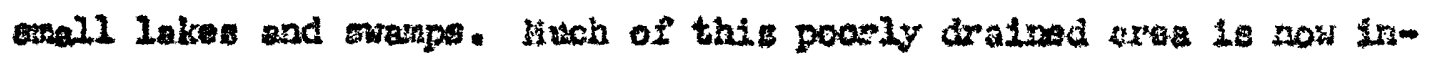
cluded in Green RIver Feservolr.

\section{Farpose of stuty}

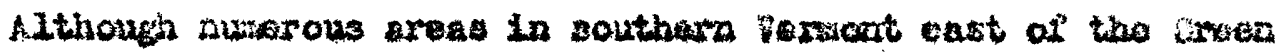

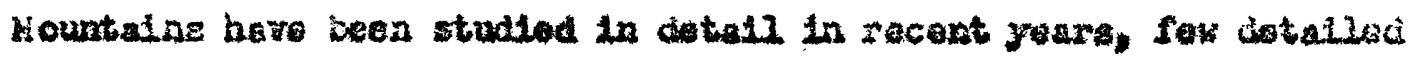

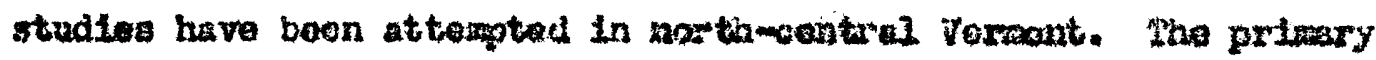
pirpose of thla worl is to dolimeata the tratlemephy and struetixe of the Iyde park quadranglo and to ralate it to the gonoral geologic framework of Vertomt. A further an 10 to discuse in detall the 
potwography and wetemarphts of this ares.

The vork was undertakon for the United statos pooloctcal skrvej:

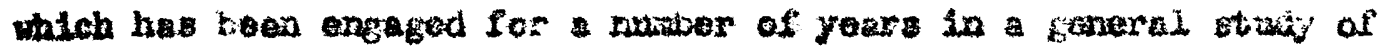

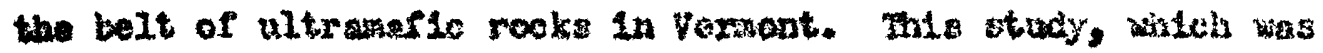
pranted by domotic mortages of abostos and cortaln grades of talc,

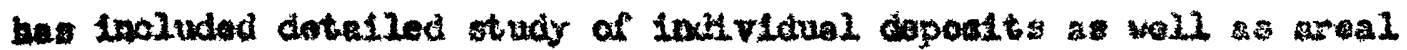
cologte mapting. The relntiono of the ultraceatic rocks to the arent

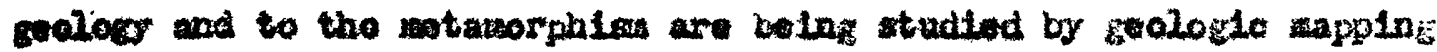

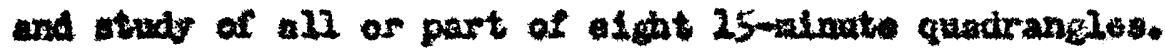

\section{listhod of stradr}

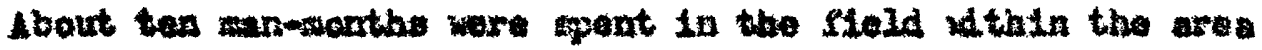

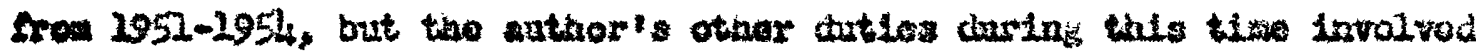

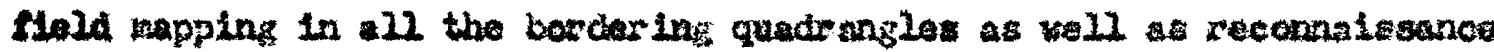
work in canadn and other portions of toxeont. Tho study of 225 thin wotione from thi area vas anplolonented by the study af thin sectionz

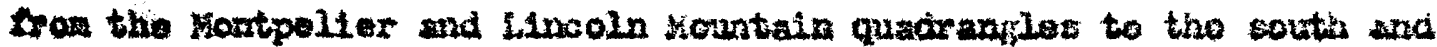
the Jey peak and Irobure gandrangles to the north.

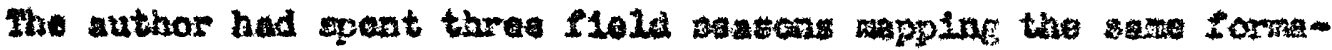
thane in adjacent areus before he began the precont etudy. In additlai ho had exaninad ovey 450 thin cectlone taken in that work.

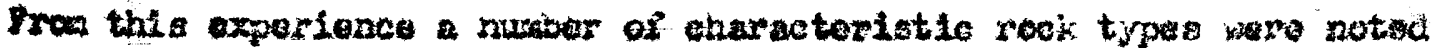
and given symbols. Thene grabals, toul for note tokins, were parthelarly valubblo for ploting litholo lc date man mas.

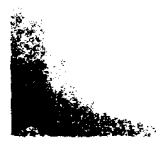




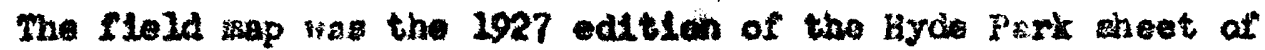
the inted toateg ceological survey onlargod to soal of $1,48, \infty 00$. Ftractural and I1thologle ciata were tensforsed to 1,24,000 anlargewents. Atout a tenth of the aree, that wich 210 in the extreso northeact cornur of the quadranglo, was mapped in grestar detall on mape (scale $1,24,000$ ) propared by multiplex thods from exial photoEraph taken in 1951. Aorial photographe (acule 1,20,000, 1,213,000) wore used extensively in loos henvily woodod aroas. Hoat of the atatlons were located by altimeter traveree, but pece and coxpaes mothode were ued ocenolonally. Contacts were trensiorred from the altiplex mep and from aerial photographs to the final compliation by ase of vertionl sketchanter. Thus, although placed in thetr propor

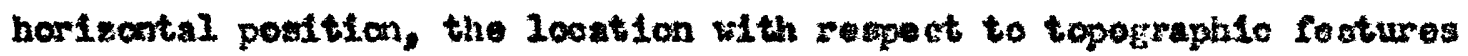
may be allghtly arroneons in a fow aroas.

The location of apocinens wioh are citod in the tables 18 iren by a convenient referenoe gyoten. The quadrangle nap it divided Into 1te nine 5-ginuto seotiong, which are deslfrated northesst, esst-central

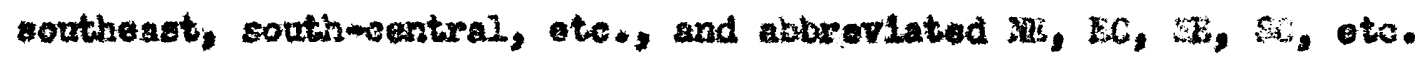
Within exch ninth the southwest cornor 10 the origin and decinal

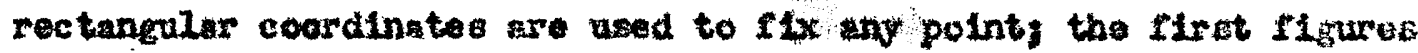

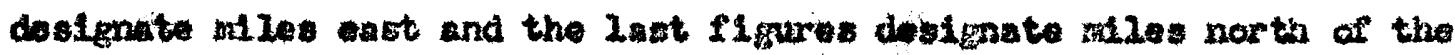
origin. Thus, $-1.05,2.03$ indictes point 1.05 ut las engt and 2.03 niles north of the southwet corner of the northuest ninth of the

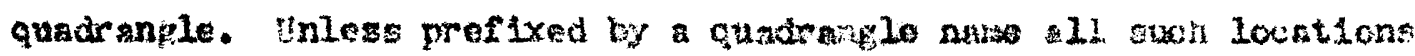

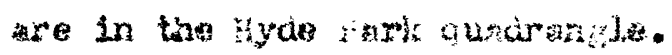




\section{Aclonowlodgiente}

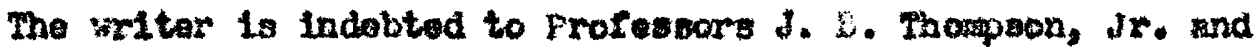

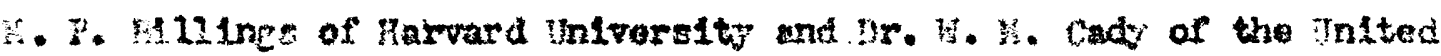

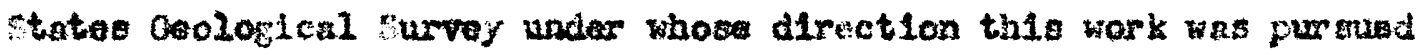
and wo gave freely of their tind for instruction and criticiar. ir.

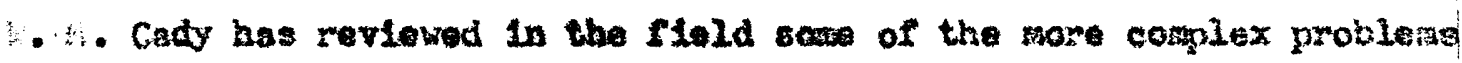
and in his company the author performed reconniseanoe work in edjacen aroas. The lnstght into the raglonal gealogie pleture given the authoi by Dr. Cady is chiorly reapenstbio for the section on regland rew lations.

Part of the Inboratory work and of the writing was cololuted While the author has studflng at harvard Unirarelty under a Hational science Foundation Fellowship. To Dr. Hans Eugeter of the ceophystoal Leboratory, Carmagl Inst1tute of hishington, D. C., I gratoful Ior

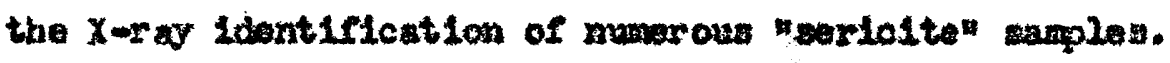

The manuserlpt was critteally revlowed in its entirety by

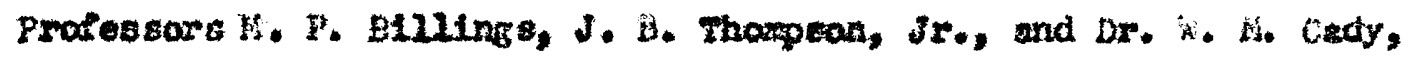
and portions of it were reviewed by h. H. Chidester azd Janala intlock, both of the linited states cological survag.

Wenbers of adjecent lleld partles provlded helpful dizeusalon

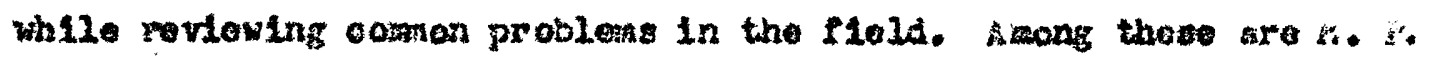
E1111rge, H. Erace, H. H. Gady, A. H. Chidoster, H. C. Cooke, J. K. Allnore, I. H. Oaberg, J. I. mononfold, J. t. Thomeron, and E-an ron. 
Finally, of olwere gratitude goos to ay wle, ann, for her assietance furing the otatiotson study of the andyoes of secinantary rocks, and for typing numerous drafts of the lamuscript turing its conpilation.

\section{Erovious vork}

Soward Hitchcook and othere in IB6I putliahed comprohensive report on the geology of Varment, 1noluctug a geologianl map. They recogntsed the anticlinul nature of the creen vountaine and delinested

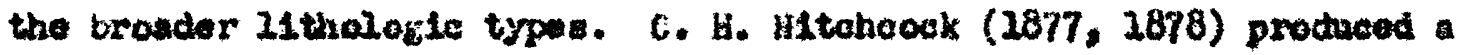

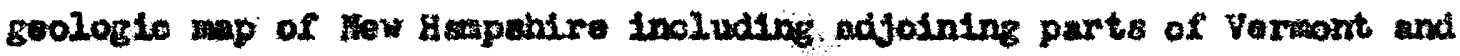
Heine vith an accompanying report. Inla chowed rather accurately the

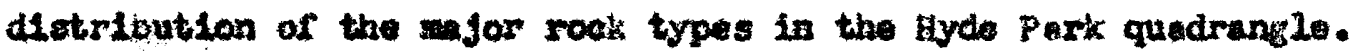
both of these roports form valuable sources of Infornation, eqpelally for the location of enall minoral prespects. No other areal mapping has bean done wthin the quedrangle. All goological maps of areas Wthin the state whlah were publiched prior to 2952 bave veen indexed on a map of Vermont (Eoardian, Loona, 2952).

The Interpretetion of the strat igraphio eaquance of central and osetern Vomont evolved to nearig 1 te precent form in serles of paper by richardson (1902 to 1927), perry (1929), and Currier and Jahns (1941). Flchardzon troced an uncanformlty (now rocognized as tho base of the chaw fiountain Iaration) fron canada to Hosachusette. The rocks atove the unconfor sity were deardbed by currite nad Inos 
(2941) and kifito and Jahns (2950). Those below the anconforad ty were deacribed in the plymouth-imldigeweter area by ferry (1929) and by Aawtea $(2940,1942)$.

Anee 1946 much of central and eastern Verront has been or is belup maped, but rery little of thi nork hat yet been gublished. it genervileed mep of the southern half of the state, including ach of this upublished repplng, was complled by Thompon (Ellinge and othars, 1952). The rocks of perry' sectian hav ben traced south and correlated with strata in Havechuedts by Thomosen (1950), LosenSold (1954), Eleman (2953), and KacDonald (umpublthod). They havo been traced north by Hawbe (1940, 1941), Thorpon (1950), Chang (1950) arece (1953), Osbers (2952), and Jahne and incte (1950) to the couthern borders of the Iincoin rowntain and fontpolier quadrangles. Cady, Albee, and Furphy here partindy completed the wapplang of the inecoln Hountaln quadrangle. Cady has completed the tontpelier quadrangle (Cady, 1956), Albee has completed the Ilydo Park quadrangle, and through Irconplete and reconnalsance apping the strotigraphic units have been carried north to the Cenadian border by caciy, Albee, and Chidester. This wark, as well as work in the southern part of the atate, is st 117 in progreas. 
Roglanal realozic ootting

The axls of the oreen sountain antlolinorlun (Plate 4 ), trendiru north-northeast, croses the extreme northwet corner of the hyde Fark quadrangle. This anticlinomian, wich is the princlpal structural fenture of vemont, extend nerth-nor thenst from the Ipssachusette border the full length of the atate and about 50 milea Into quebeo, a total diatance of about 210 adlos. In the southern helf af Fernont Procambrian rocka are expoed in the core of the anticlinoritur. rest of the Green Mourtain ant1clinorlun sllghtly watarohosed linertane, dolopits, quartsose sandetion, and coms thale are exposed in a broad bynolinorium. These rocks rest with pronowed angular unconfority upon the Precambrian of the Oreen Hountains and fossils indioato

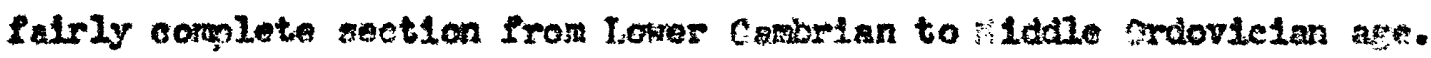
These rocks of the veetern oymcilina are folded and $c$ ut by mums rous thruat fonlts.

On the east the frecantrien rocks are ovorlatn, agsin alth pronounced angular unconforalty, by thick cerles of metasedimentasy and metaroleante rocks. The upper part of this eastern tation is eparsely

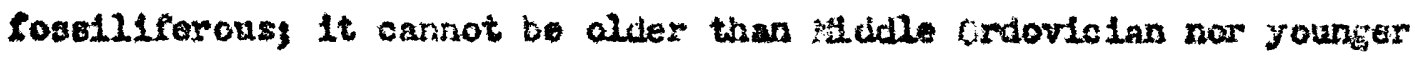

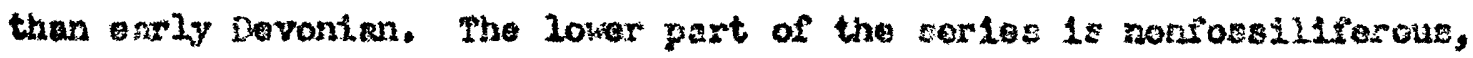
but is belleved to include cambrian and early oriovician roeks. in though precumaly equivalent in a to the sllghty metanorphoted cerbonate rocks and quartzose sandetones to the west of the creon

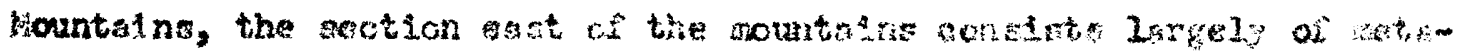




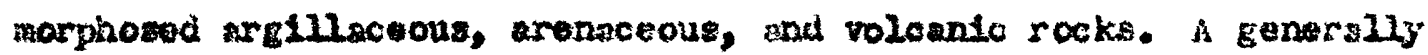
accepted correlation of the eastern and western gectlons in not jot poesible beonuge of the ent-west change in sedinentary iacios (Thompeon, p. 1h, in L1111ng and others, 1952). The oreen ounte anticlinoriun plunges fently northward so that in the northern pert of the stat the Prleozolc gnolsses and schtsts bridge the anticlinorium in aries of folde. The difficulties of correlation in this area and the dotalled reglonal rolations w11l bo described in Later ection.

The general features of Vermont we markedy sladlar to thoge in the Eerkshire Hills of hassachusett and the glve 3 ldge jountsins and Pledmont of the southern sppalachlans. In each of those areas there is

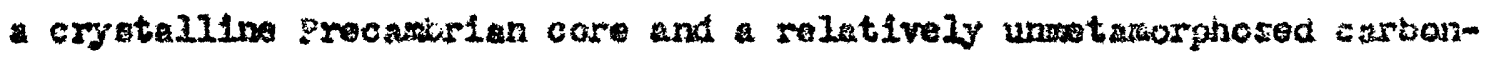
ate and quartgite sequence to the seat, festing uncouforingity ugon trie

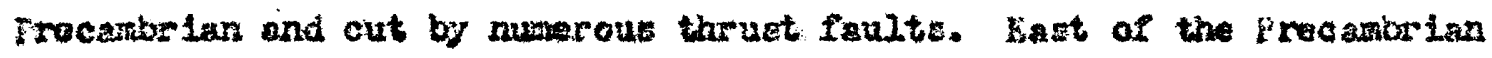
core in each area thore is a metanarphowa argillaceous-arenacecus sequence of poszible arly saleovolc see. 


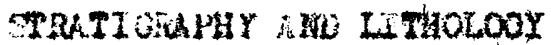 \\ Cenerel atsterant}

The bedrock in the Hydo Park quadrangle 10 predoninantiy motamorhosed sediwentary and volcanic rocks, wouly zchist, gneiss, guartsite, phyllite, greenstone, and mphibolit, but aleo including slate, conglomerate, eranulite, and impure calotte male. Ineso rocks have been Intruced by lawprophyre dikes and by ultramaflic rocks; the latter have been partily or wholly altered to sorpontinite, talccarbonate rocks and steatite.

All of the rocke except the lazprophyre dikes bave been affected by reglonal wethorphist. Chlorite, sarnat, and kyantt have ceen interpretad as ouccessive Indicators of increasing atsiorphic grade In the ateacoous schlot. "1rilariy, chlorite, sctinolite, and hornblende are indieatore in the greanstono and auphibolite. sost of the Iyde Fark quadrangle in in the chlorite zone. In the higher grade part of the chlorite zam elther chloritald or blotita occur deperding uyon the alumina content. Elotite is rare in the Hyco park quacirangle, but chloritoid is $100 a 11 \mathrm{y}$ abundant in tho tow fordation. The enrnet and kyanite cones are confined to the ctove formation in the southeastern part of the quactrasple.

The primary conelderation in definine forsations was to utillee mappaslo rook units which correspond 78 clasely as possible to unite already dofined in adjaent arans. It wa neceasery to be fanjilar with type soctions described many itles to the scutin, apecially those 
In the loodstock and Ludlow quadrangles (Perry, 1927, 1929). However certain formations, which are charscterized by a patior distinctive and uniform IIthologt in the type section, cannot be distingulathed on the 8 ame bast in the Hydo fark quadrangle. Thej have been traced northward from the typo aections, atterpting to take secount of gradud

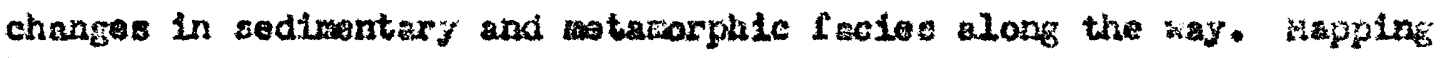
has toen partialy conpleted in sore of the intervening quadranelos, but in others the unita were traced by reconnalswance work. Th1 correlation is sumarized in later section and in Table 15.

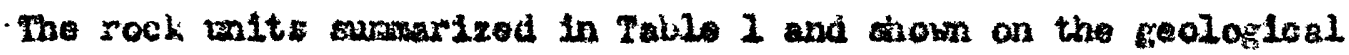
map and crose sections correspond as closely as posalole to the type wits. Fxeept for the farella Hill foration, no formetion contains a completely distinetive type of roodingarly the base rocks any be found In each of the unlte. The lack of dietinctive rocks and sequenes made correlation diffloult between the rocks on the ant stae of the ryde park quadrange and rocks in aymeline in the poot Brook area (the Foot irook ognelina) in the northwest part af the quadranto.

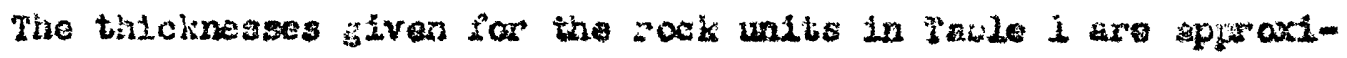
mations thet doponi upon the intorprotation of tie wap pattern. The

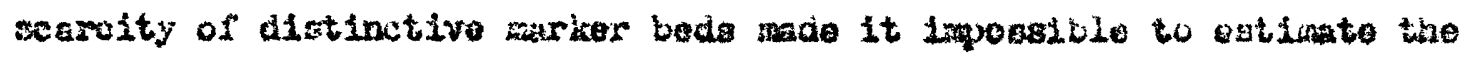
anount of repotition in most part of the quadranglo. andi folde are extrualy abusciant and it 10 apparent froas the patton of the

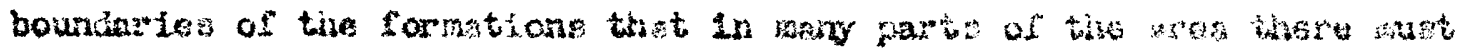




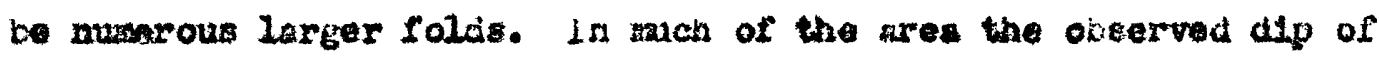
bedding and bedulng achistosity is very diffarent from that of the

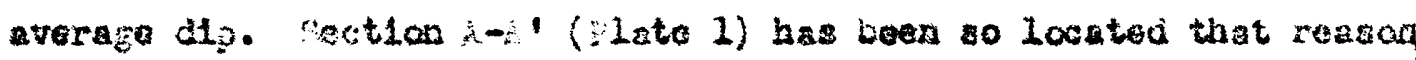

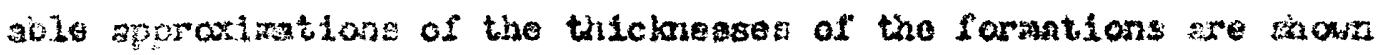
upor Lt.

The ogos assignod to the units are tentative as no fossils have boen found in any of thes. Southuet of the kycio paric guadrangle in

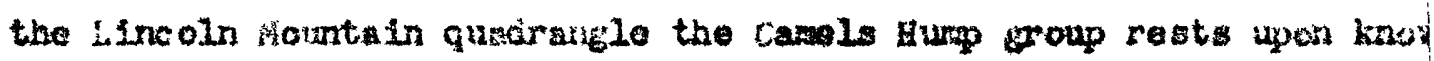
Brecambrian rocke with pronounced angular unconformity (sol alao cady 1956 and obborg, $1952, p .24,34-38$ ). The voretom formation is probably Ordovielan accoringe to currier and Jahns (1947, p. 2496, 1506-1509), who based the age deglgnation of 1tg equirnient, tire Cran H12l forration, upon thelr correlation along the etrias with

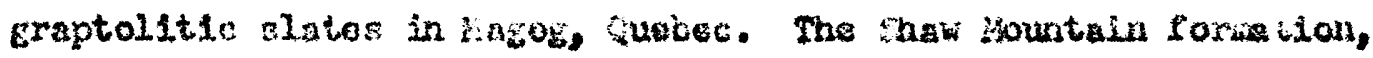

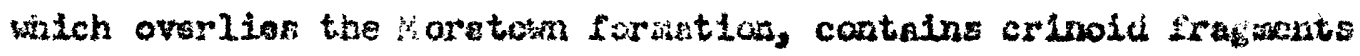

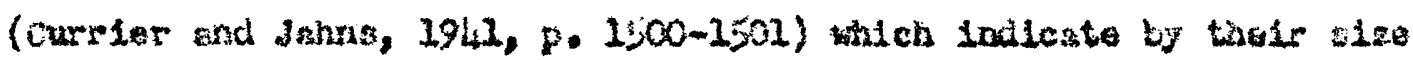

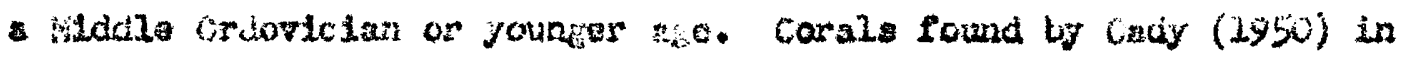

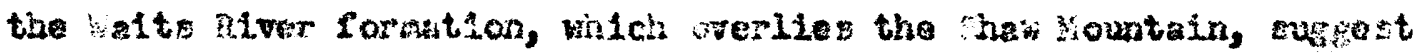

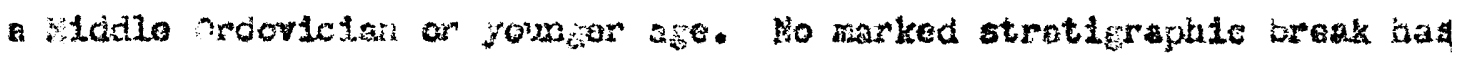
bean found from the calsols ato through the frotom formation, and

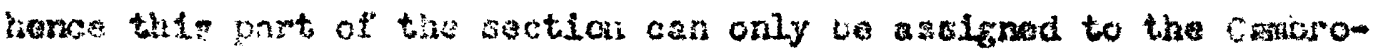

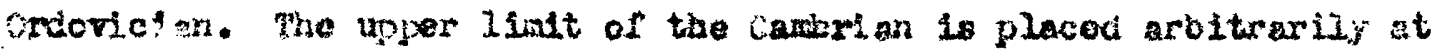

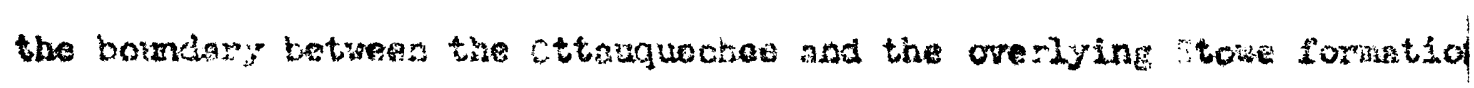

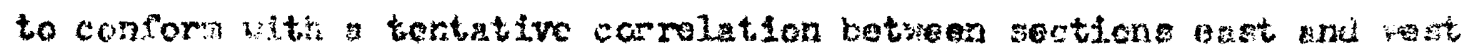


of tho ineen sowateins derived by cady and the author from the resin

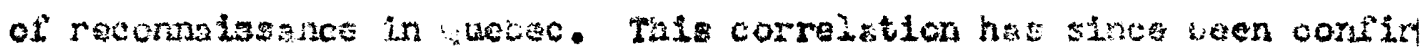

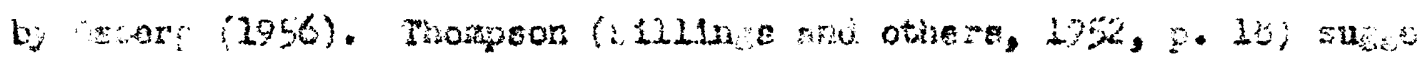

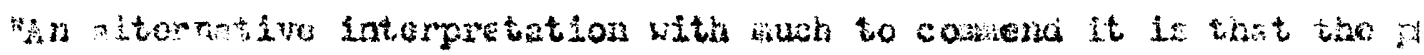

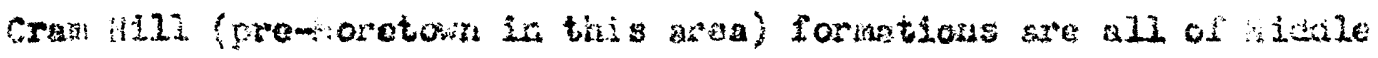

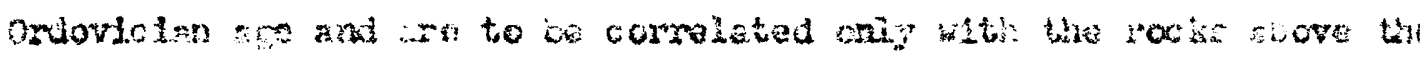

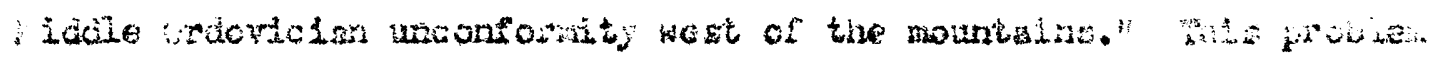
Will be ilecusead in nore cotail in a later section.

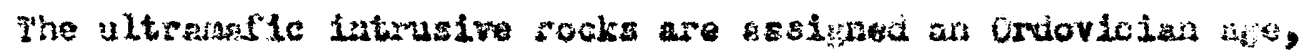

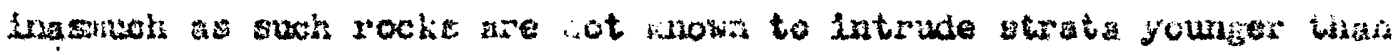

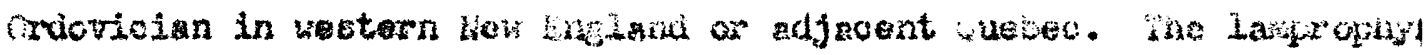

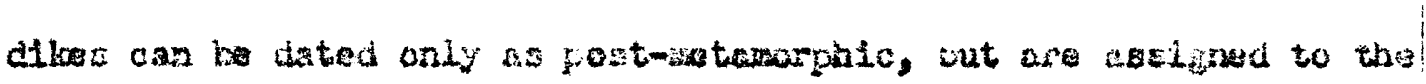

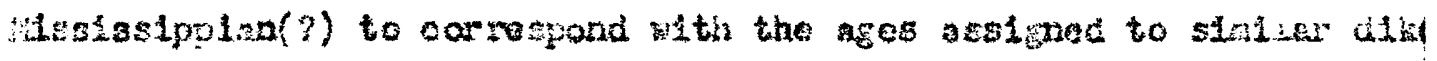
alcig the connectout aves (thite and 1111ines, 1951, p. 652).

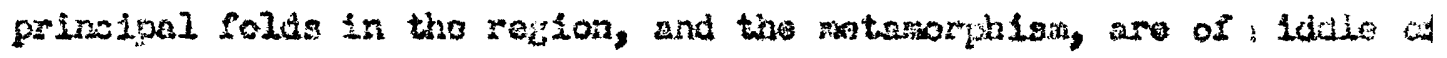
tate Devonian a 695.) 
joretowa forsation: 5r andite vith close-spaced meaceous partinge, niceceous quarteite, and serloite elate.

Eabrell 111 formation:

puarts-pabble and alate-petule conclonerato wh thin interteds of cericite glate and thieker interbed of friable caleareous alate; cortialn abuadent chloritold,

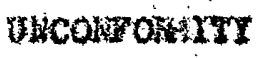

stche foration

Ippert

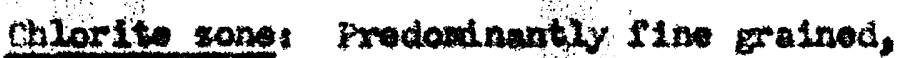
thinly lasinated, serieltoguartz-chlorite-albit schist contuining nueareas thin lenticles of guartz. Greenstone, graphltic piglilto, calcareous Greonatone, and calearoove phyllit to are mino: litho-

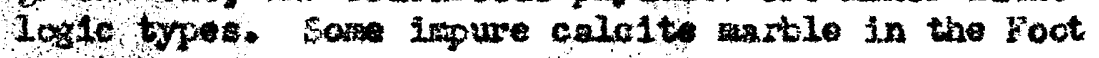
trook trea.

Ganot and byante zonge: conreo-gralned, quartzmascovite-ahioxite schiet whioh containe porphyroblasts of chlaritoid, garnet, and kyanite, and

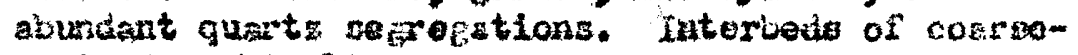
realned exphibolito are presont.

$$
\text { bidalo: }
$$

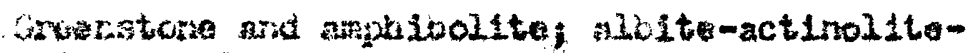
eplate-chla ltemarbonete groenstane in nortiarn cat ares; horablende-opiátotoloite-quartz ardifiolito in southern part of areas includes soso lateriods of nicacoous schist.

Solser:

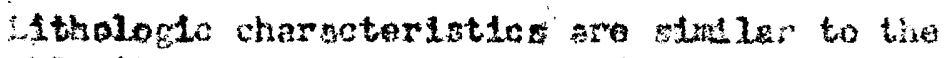

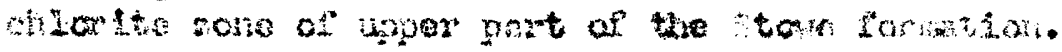


2ABLI 1. Stratieraphic section - continum.

Ottauquechee formation:

Black graphitic quartz-aericite phyllite and schlst and maselvo dark-gs quartzite in southarn two-thirds of quedrangles graphitic phyl21to, pebbly guartsite, and pobbly quartzserlcite schist in northorn part. Guarteite wth aloaceous partinge and orieste-quurtecinlorite phyllite are ulnor rock typer. Thlokmase in root wrook areas t 600 reet.

5
5
8
8

Camels Bump group

orrar 5000 Fredoninantly aphitio schist and quartalto with interbeds of nongraphitic sebiot and carkare massive quartelte in cuntral and southorn part of quadranglos predonimantly prajhitic and nongraphitic querts-andeitemionite sehist and

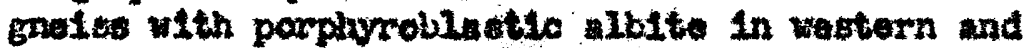
northern part of quadrangle. Slivor-green quartzEarlcit -hloritemangatitemalbito sehist forms oevaral mo unttas one 10 as ach a 800 feet thick and lies st the top of the Cansis Huse group in the southorn half of the quatrangle. The selvidere sitn. emplibolite, as rach as 650 feet thick, 1100 at tho top of the Cessel Hume growe in the northern part of the cundrangle, but fingere out southward.

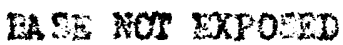


Gotenor hosed sedinentary ond roleanto rocks

Camals hiutp group

Goneral statememt.

The Canels Hump Eroup (Cedy, 1956) Includes the schist, meise, quartitte, and other less comaon rock batween the known recanicrian rocks and the base of the ottaxquebe formation. The base and the lower part of the Cands livap group are not exposed in the Hyds stirk guadrangle. The Ganels Hum group Lneludes part of the Hount Holly canplex as used by Oaberg (1956, p. 21-26), and the Nonnotery, Cren-

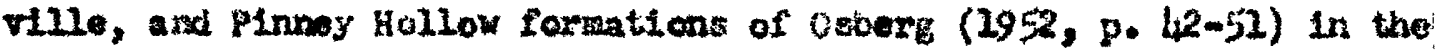
Rochestar ares. The lattor throe fornations oceupy about the name Etratieraphic poaltion as the pyson, Hoosac (or Orahamille), ano

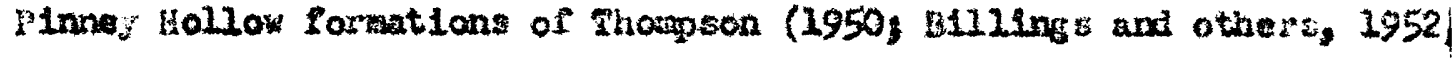
p. 40-41). and Erace $(1953, p, 45-50)$ in aron to tho south of rochest It has baen posslblo to trace northuard the general correlation at thi

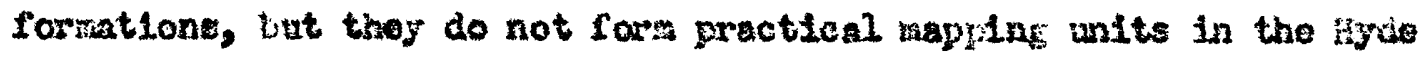
Fark quadrangle because of 11tbologle change along the otrlke.

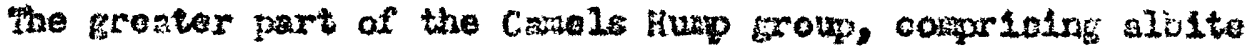

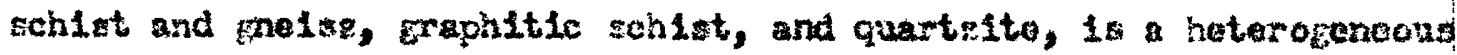
unit with a wide range in compostion and graln alo with in the quad-

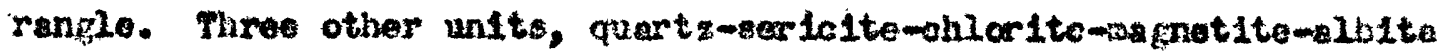
schist, preenntone, and the relvidere Nountaln arahibolste, sere mapped and are descriced serarately. 
101te gchist and moles, uraphitic gchlot, and quarteite.

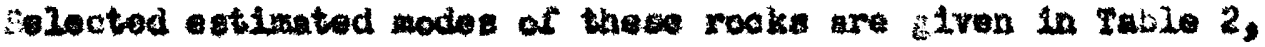

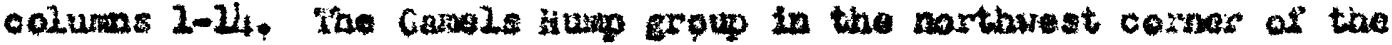

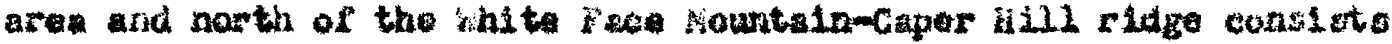

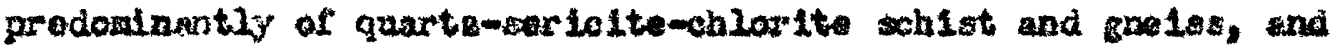
graph1t10 quarti-seriofte-chlorite sthist both fith porphyroblastic albito. A good eactica of the roeks in wposed from gelvidere Junction, southeastrard over Iarawey fountaln, and along the Oroen

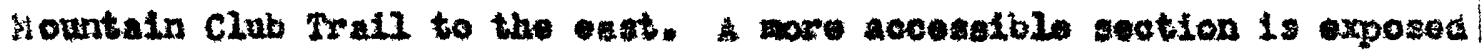

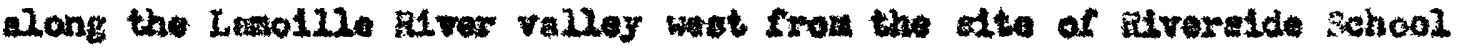

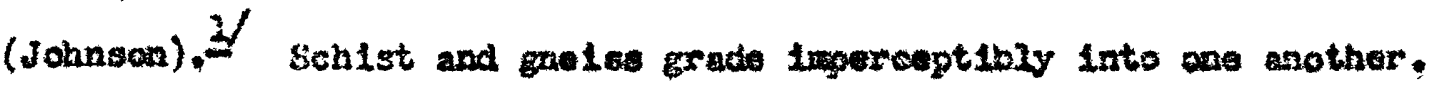

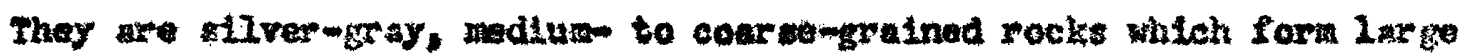
mooth outcrops. Liblte porphyroblasts comanly range from 3 to 10

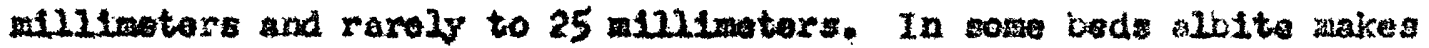
up about 25 percent of the rock. quate, sorielto, $2 /$ aluite, and

y rhle notation whll be used throughout the pajor to refor to the town In which the fasture is located. The rord "Elte" is used because meny of the school show on the map are now abmdoned.

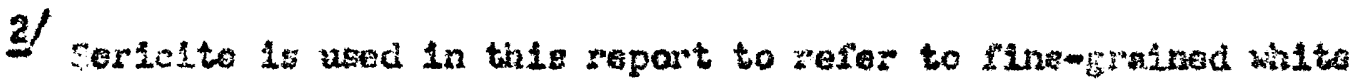

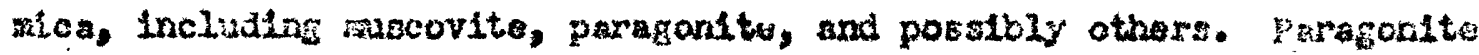

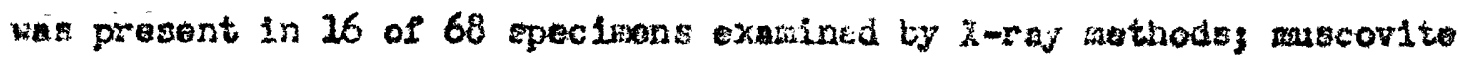

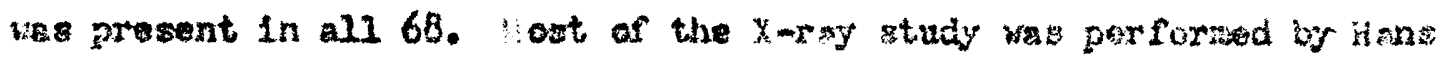

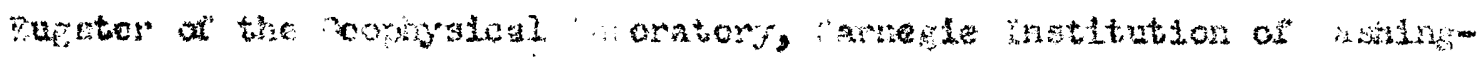

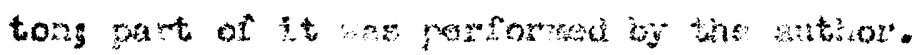




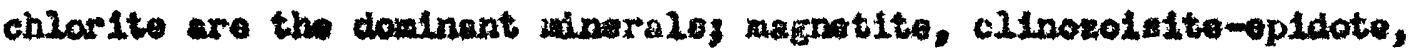
and tourmalino are the comon accesscry minerals. Mlong the creat of the sterling Range a littlo west of the Hyde Park quadrangle tarnet porphyroblast are present. Suall euhodral garnot cryotals anclosod In albite porphyroblats ware noted in thin sect1ons frow the camels Fuxp group on the weat olde of the Fyde Park quacirangle. Loenlly, friable weathered rock indicates the presence of earoonate. Inyera rich in quarte alternate with 3 yyers rich in sorictio and chlorite, and the platy rinerals aro arlented parallal to the layers. ienticular aggrogates of quarte parallol to the follation and irrogular quarte roins, that lecally contain calcite, chlorite, ancilolte, aro abuniant| Hweroas bede of black and alite bended quartalte, 3 to 12 inches thick, are exposod with the gheles on the south wope or Laraway wountain, but fows lowant southward.

The quartz-serleite-chlorito sohlot and gne iss with porphyroblastle alisto is very Irregularly lateriedied with graphitic guarti-

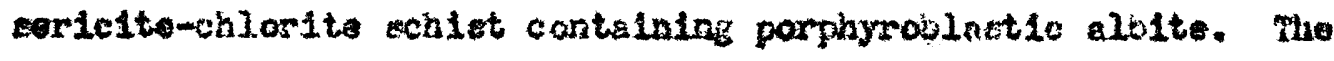
thickness of the Interbeds range sromeveral Inches to zovernl hundred yarde. The gronitic achiot to siallax in general lithologic characteristice to the nongraphitio schiet, but is iner frained and more sehistose. It $18 \mathrm{gFay}$ to slack, wathers rusty, and containg sone

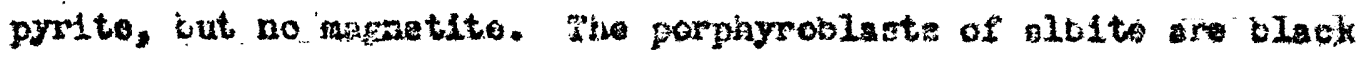

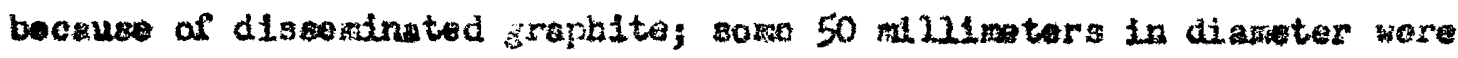
noted near lelvidore Junction. 
In the southern and central parts of the quadrangle the camele Hum group is mach Iuner gralned and quartalte is zore abundant than In the northwest part oI the quadrangle. Oraphitic schist with s vide

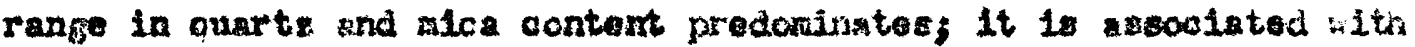
micaceous cuartz1te and andve gray quartzite.

The eraplutic schist and quartelte are characterietienliy gray to b2ack, contain eporadic porphyroblaste of pyrite, and are rusty wethering. singlo group of outcrope comonly contains the followins intergradational Iithologle types in tho following doareasing order of

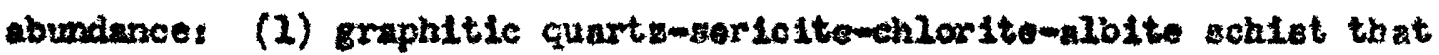
predes into a more wicacoous grachltle quartz-borteltemoblorite phyllito or intio extrensiy quartgose graphitic schiot wth thin mor-rich layers that separata quartz-rich lnyerg) (2) nomgraphtic quartz-gariattem chlortte-albite schlot; (3) alcaceors quartate, both graphitic and nongraphltic, with discrete poper thin cchletose partings complesed of

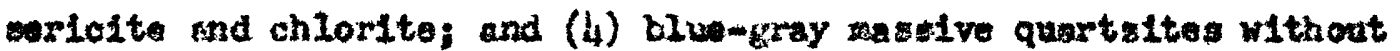
follation. Outcrops showing this characteristic intarbedding are ohown

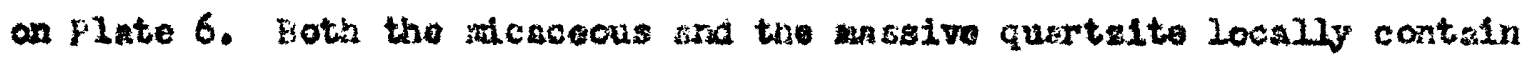
coarse dotrital gratns (granule sad pobile glte) af quarti. the

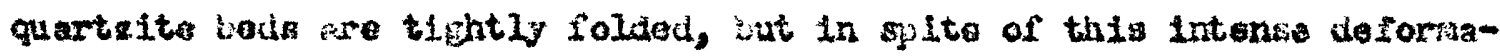

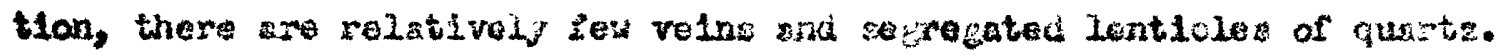

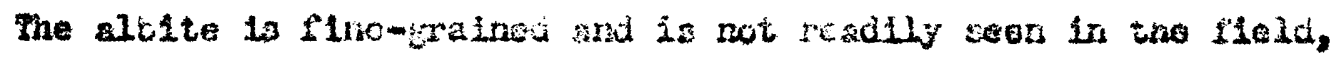

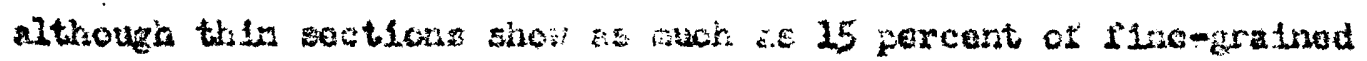

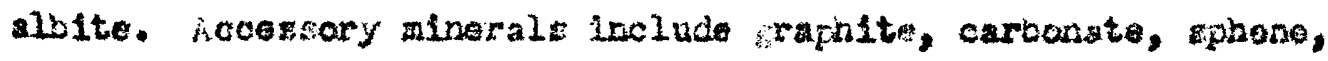

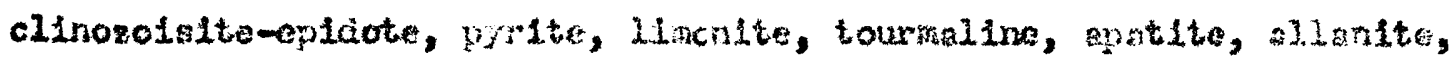


and elreon. The thlclinees of the layers of varlous lithalogle typos ranges frow a few inches to overal tene of foet. The rane in rolative proportione of each type is not consiatent enough to dufine appale untte. Mick blue-graj masolvo beds of cuartite ato abundart at sevaral localitios, wut they can be traced for only a shert dintane alont the strike. All of the rocks are rell timposed In the notion of roads betwean Joknson and centervillo (lyde fork tomahis) and in toring krook (Morristokn).

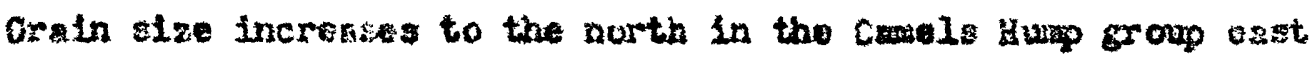
of the Foot srook area and the alcaceous quartzito becowe quartzmpite-chlorite-alulte gne1os, the graphitle sohiot and phyllito becos gropitic quartz-seric1to-chlorite sehist ith porphyroblasts of black altite, and nongraphitic cenlst becomod quatz-coricitealbito-chlorito sehist and gne1se. Slbito ocure as porphrrobladte

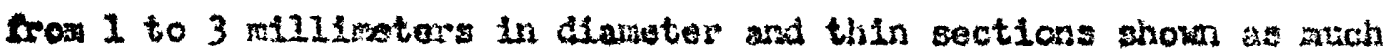
a 35 percent albite. regregted lenticles and volns of quart? are wre sbundant. In the northern thind of the quadrangle the rochs of

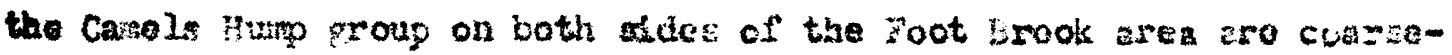

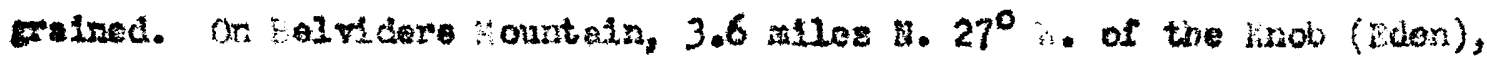

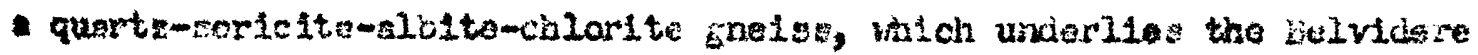

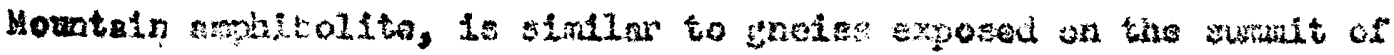
Loraway ountian. 
Figurea 1 and 2. Outarops of Camels Huxp group shoving trplenI

11thologle features. Wote tho Interbedding and quart: cegegations, 0.80 wile $5.85^{\circ} \mathrm{W}$. of the atte of N1anell School (Hyde Park). 


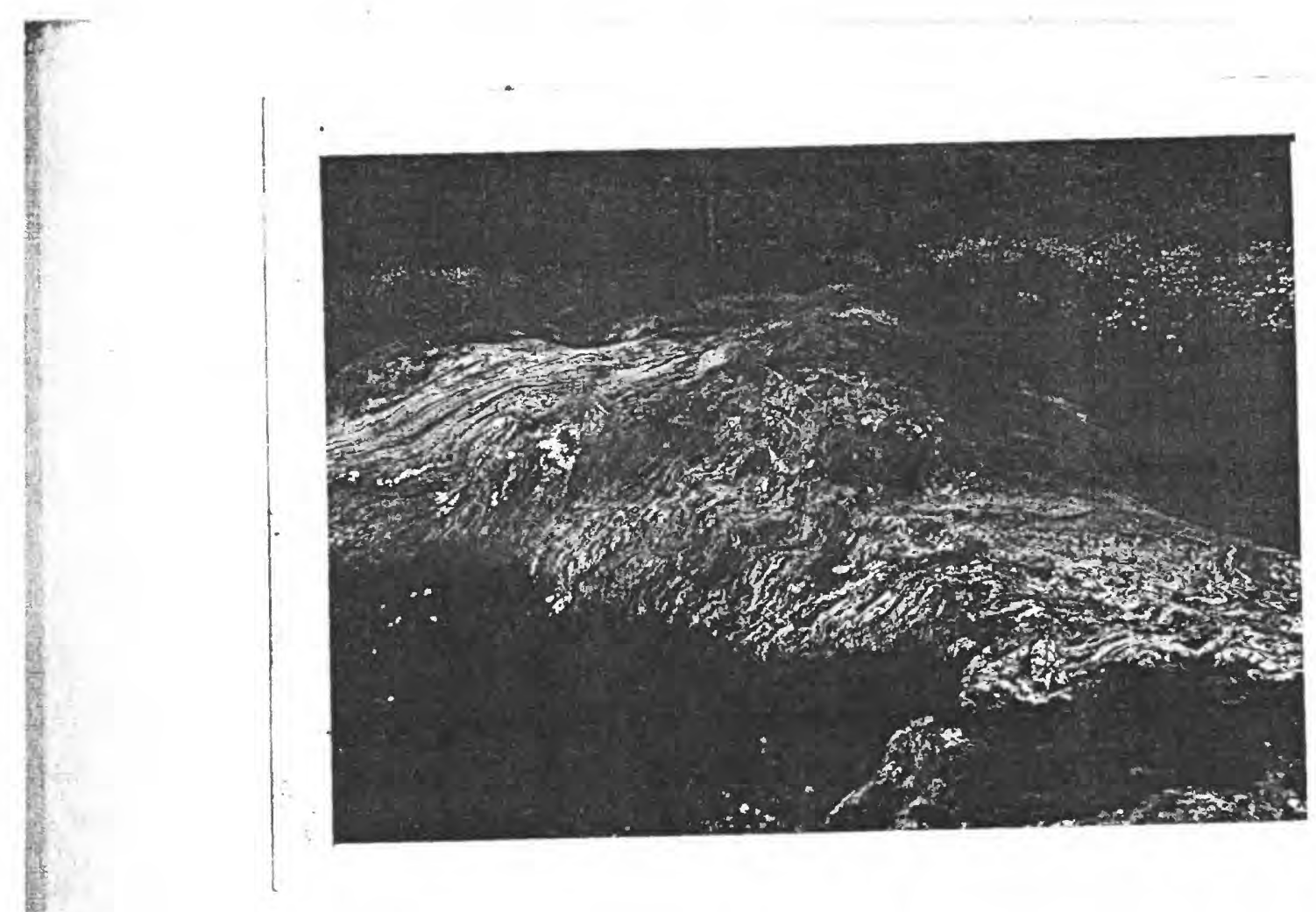

pigute 1

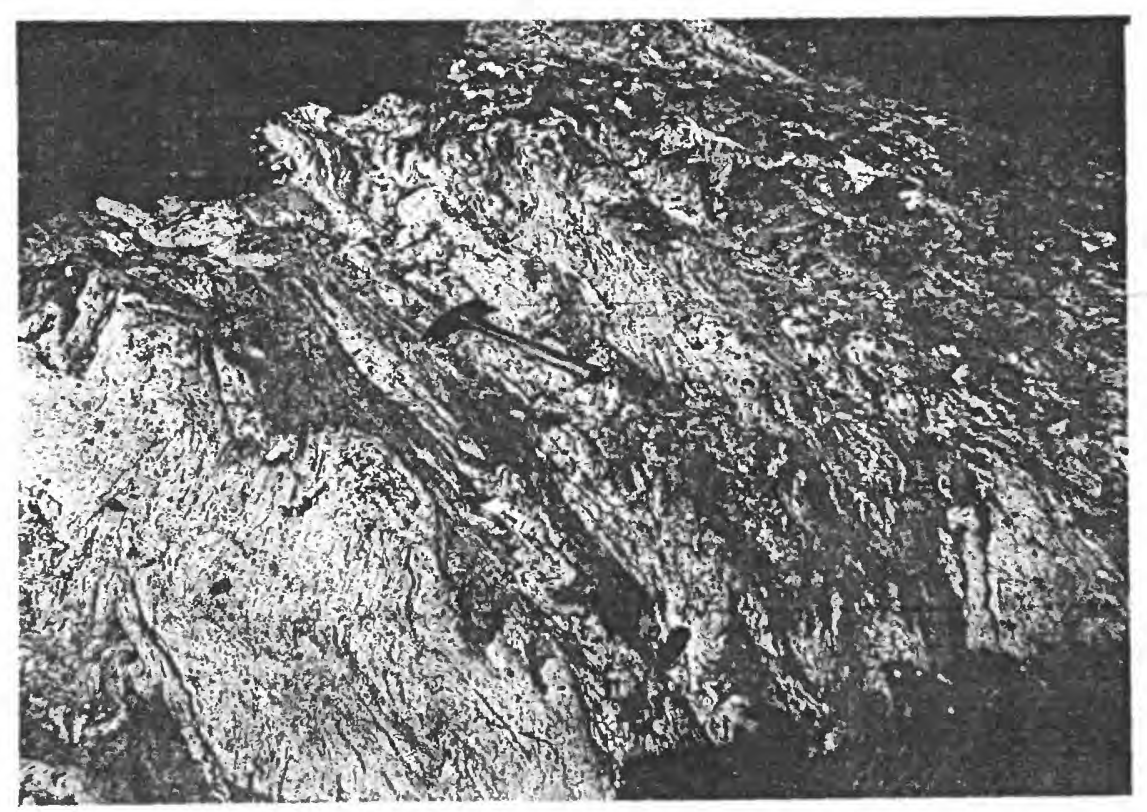

30

21abe 6 


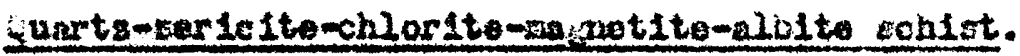

Felectod modes of theso rucks aron in sable 3 , colusins

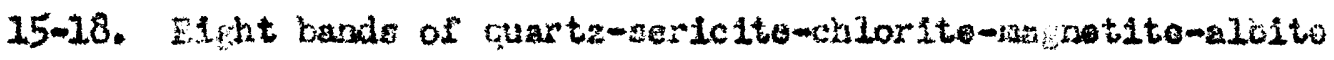
schist are shown on the guologle mep. These will be saforreu to

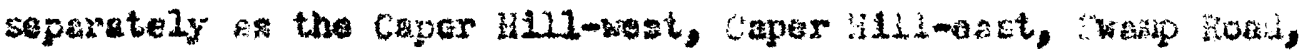

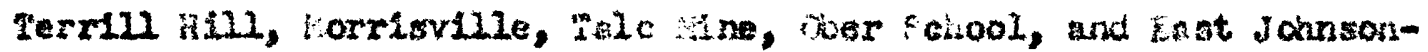
Hyde park iands. The clach ilvor-green color of tive weatherea outcrops and the grezence of abundant manetite ostahedra (1 to 3 millineter across) contrasts sinarply with the genoral dark color, ruaby-ionthered surface, and praphite-prite-ilmonite content of the roks that surroud wase badt. Aowever, cuartw-soricito-chloritem

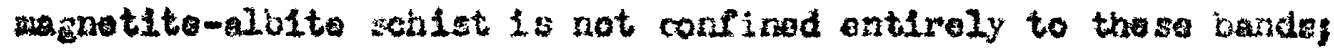

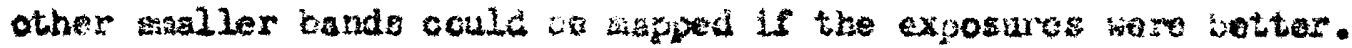

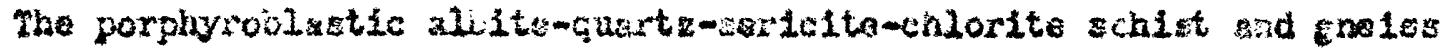

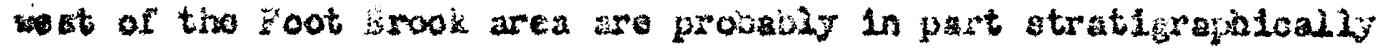
oquivant to these soinit iands.

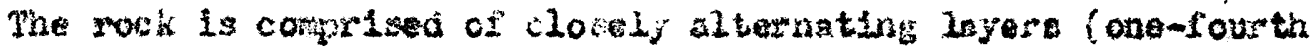

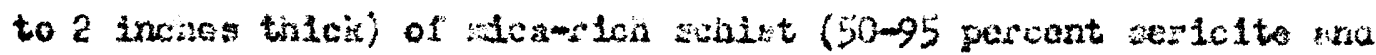

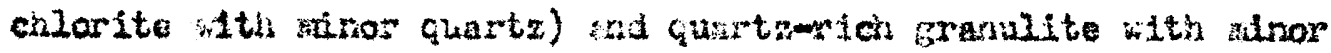

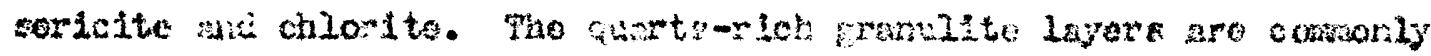
thiner. thar the silcacous lnyers, perallel the scinstosity of the atcacooun layers, and probably represent owloinal bedine socally,

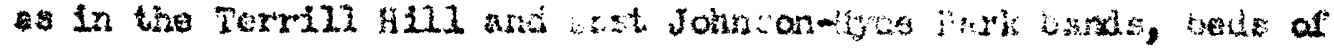

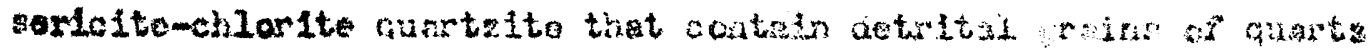

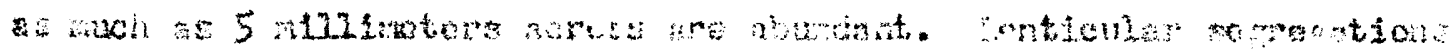


THLE 3. Zatimated nodes of the Camels Iump group.

\begin{tabular}{|c|c|c|c|c|c|c|c|c|}
\hline & 15 & 16 & 17 & 16 & 19 & 20 & 21 & 22 \\
\hline usat 2 & 50 & 12 & 1 & 42 & 3 & & & \\
\hline Slofte & & 3 & 5 & 20 & 57 & 25 & 28 & 25 \\
\hline Serleite & $30 \%$ & 70 & $50: 4$ 留 & 10 & & & & \\
\hline chlorite & 18 & 10 & 40 & $<1$ & 13 & 28 & 10 & 3 \\
\hline Motste & & & & 15 & 2 & $<1$ & $<1$ & \\
\hline ictinolito & & & & & & 5 & 25 & 50 \\
\hline Magnetita & 1 & 5 & 4 & 1 & 1 & 2 & 1 & \\
\hline \multicolumn{9}{|l|}{ Craphite } \\
\hline Carbonato & & & & 1 & 5 & & & \\
\hline Epldote goup & & & & $\therefore 1$ & 25 & 40 & 35 & 30 \\
\hline Fyrite & & & & $<1$ & & & & \\
\hline
\end{tabular}

Inowito

Spherse

1

Fut110

Apatite

tr

Tourmaling

tr: $<1$

*⿻十 *is

Loeationg

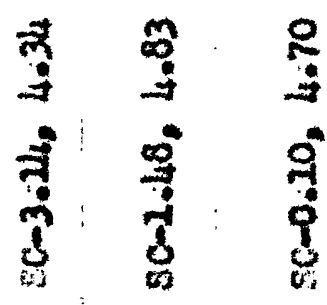

$<1$

tw

4

2

\footnotetext{
Huscovites paragonste absent.

it: 20 of of serictte is paragante.

* Explonation on paee 5.

15. pritz-serleite-chlorito-magnetite-albite schlst - Forrizville bind.
}

16. unte-sericite-chlorite-paguetite-aloite schist - Terrill Hill band.

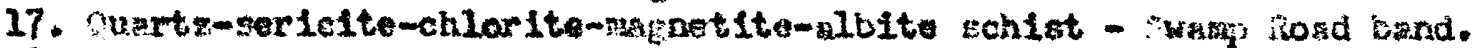

18. wuatz-gericlte-chlorite-na netite-alite schist - Capor gill sost band.

19. RIb1tic Eeenstone rone in Garels Htwp group.

20-22. Selvidere Kountaln arenibolite. 
of quarte parallel to the schiotosity, and Irregular pods and roins

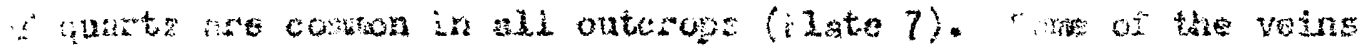

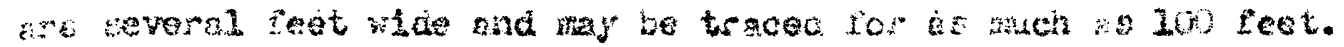

The ragnetite cotohodra sre sost bundant in the leyor rich in wicaceous minerals. The albite content ie iow (0 to 5 yercent) in

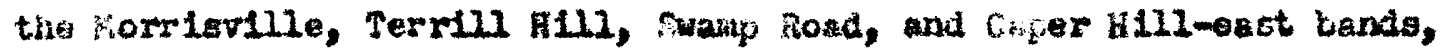

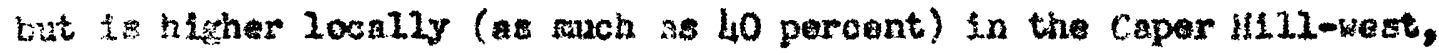
and higher gererally in the galc ine and ower sohool bands. Faracontte 1. present in two of the four opeclaens stwiled by $x-r a y$ methods. Accessory fnersis include rutile, 12menite, sphene, tourmaline, apatite, zircon, and clinozolsito-epidoto. The zoutiern bands are

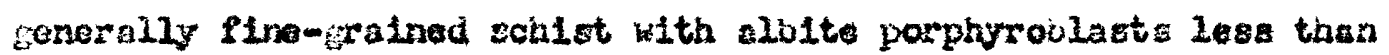

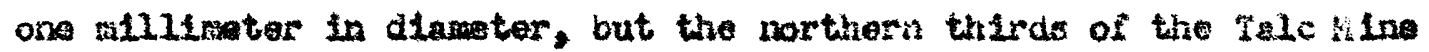

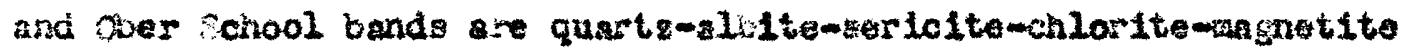
echist and gnelas.

oxe lithologle features are pecullar to cartain of the bands. The rorrieville band locully contalne beds of limestone frov half an inch to 2 inches thick, and simlar beds of 11 sestone $a$ well as bede of greenstone have seen noted in sowe of the other baxis. foout 35

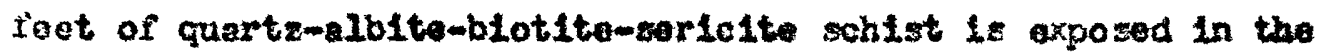
Ennollle Fiver little south of the villare of Johnson, ferd similar rock crops out on Ceper H111 in the Caper II111-east band, the sind lority angoeting that the Caper Hill-est and west bands correrge undar the cover just south of ataran irook (Johnson). 


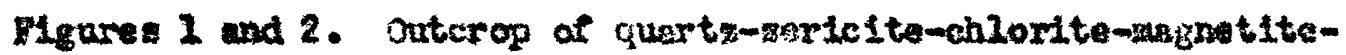
albite sebint in Terrill Hill band. West ulde or Terrill Rill (Morristow). The wite lauina and lenticios are quarts. 


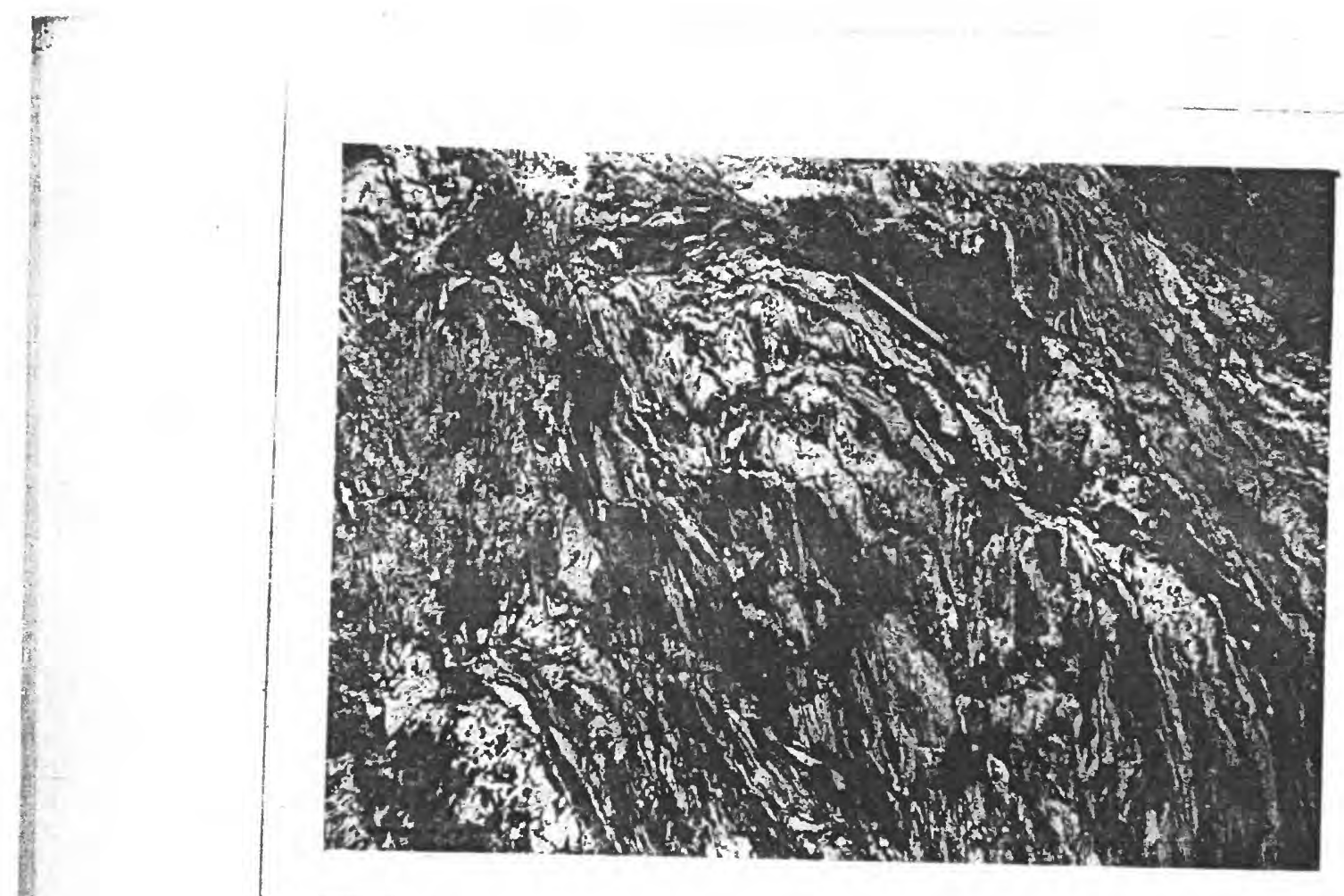

Fitro 1

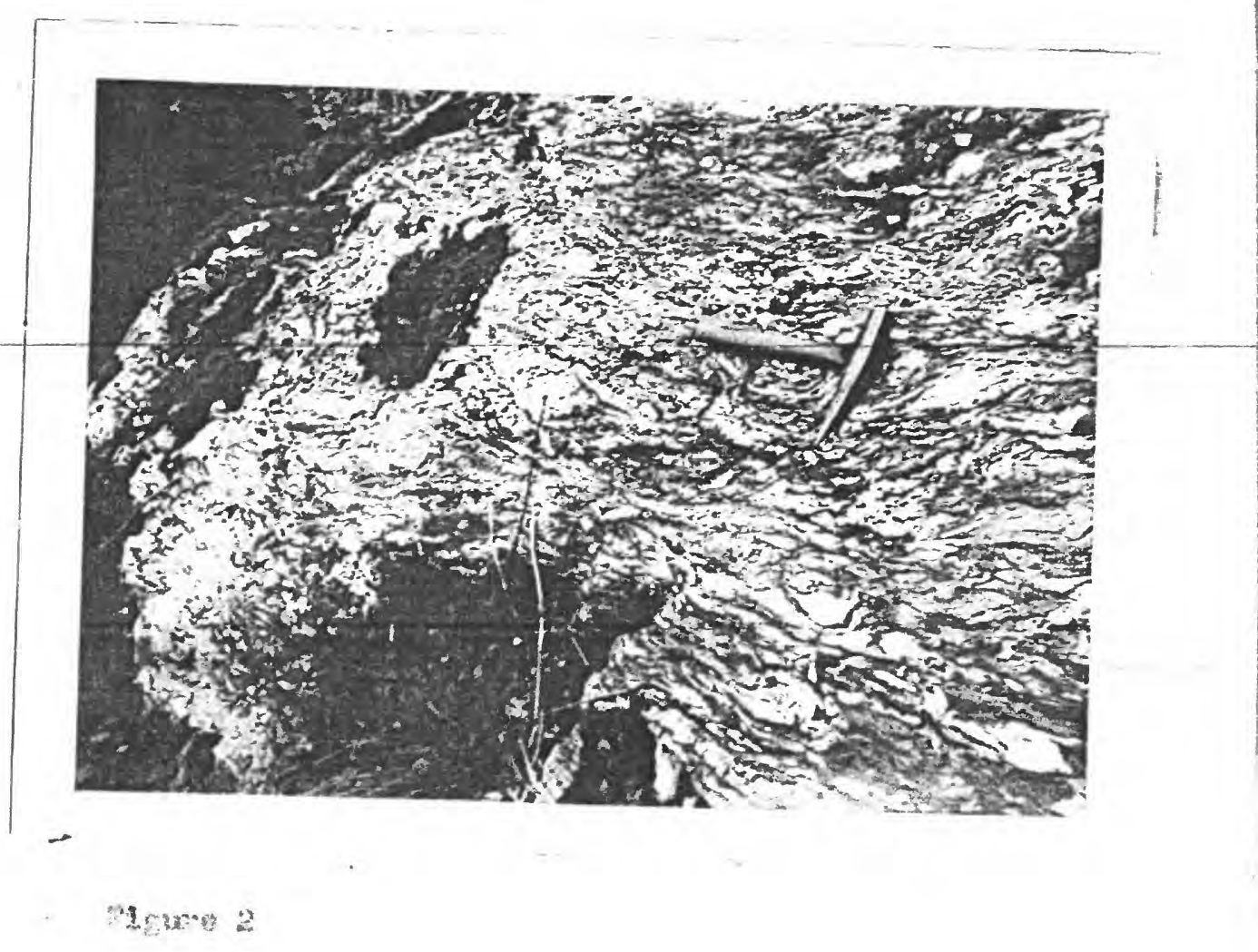


The quarteftic Inminse snd guert: lentlolem ere lutensely

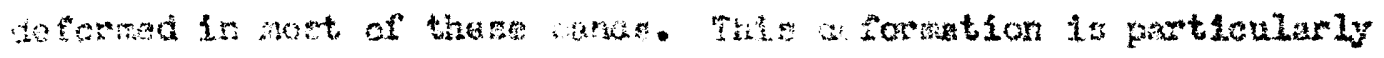

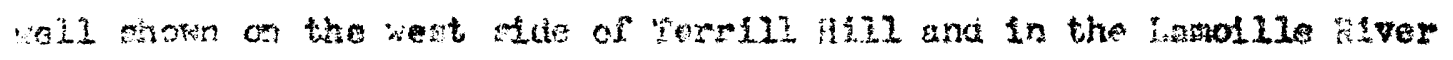
th Johnson. In these sreas the landnse and lentlcles of quartz are tichtly folded, are comaniy thickex in the creste of rolds, wh are comonly intensely shoared. Those hear suriaces (ahow on the

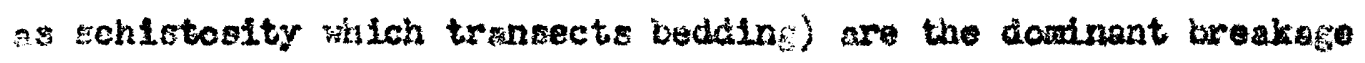
planes and are comonly subparallel to the long lisos of the rolds. Forizontel sectlons of indirtcual laninae or lenticles aro thaped like an elengate ngt of seroll. The folde plunge stoeply both north and south and thatr novezent sense is both dextral (ofrests to the right in plan) and einistral (offets to the left in plan). The over211 trend of the bedilng is comanly indeterninte. The trace of the laminae and lenticles on the cehlatosity suriace senther ont to forn bande of quarts paraliel to the axes of the steeply plunging folds. The thickened crests and axes of these steep fold and the quartz "bands" are foldod soot subhorizontal axes that trend a 11tte east of north, parallel to the axis of the Green hountain antielinoriua (we Figure 2).

Slip cleavage is in places extrenely kell developed in the axcaceous lavers, but only poorly developed in the rore quartioen lajers. In the alcaceou layers it 10 comionly the dominant euriace of breakago, and rarely completely obscures the oniller follstion. The pattern of the orly coxpositional lavaring lo such afesceous 
layars 18 preserved only by differences in the distribution of quartz

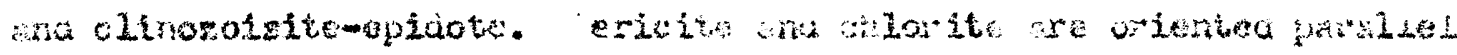

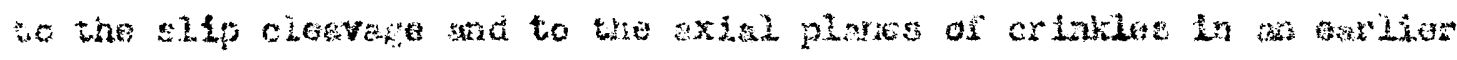
schistoalty.

The pattern forind by the be band, tho litholondo intlarity, and the Ifck of sedimentary or struetural avidence for tho direction of tope of beds sizgert that anj che of the cuartz-sericite-chloritonanotite-albite schist band could de a synolinal outiler of the orrioville band. On the other hand, ntror differences in 1lthologle characterieties and the apparent gradetion of the Tormill IIII band into alcaceous quartzito to the south suggests that the bande reflect cediventary facies variationg. The relotive movenent parallel to the bedding folfation fndicated by ainor folds on both the east and wet aargine of the foper H1ll-weat band in totersan frook (Joinson) and in

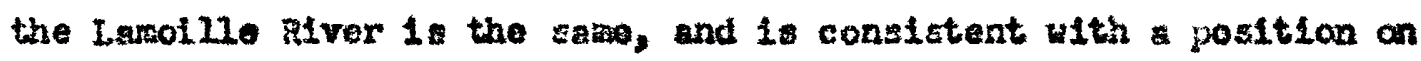
the east limb of an sat1cline. The bands of quartz-serle1temahloritemagnetite-albite schist are ghown as sedinentary facles of the carrolo Fuxp group on the structure sectlona, but it 1s poss1310 that on or more any of the other bands repeated by folding.

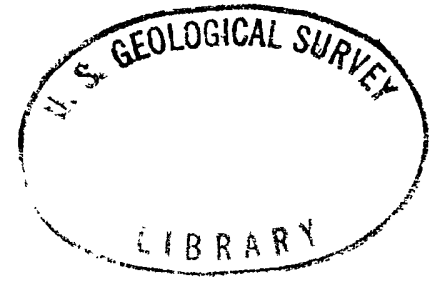




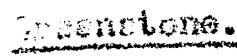

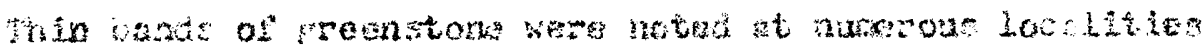

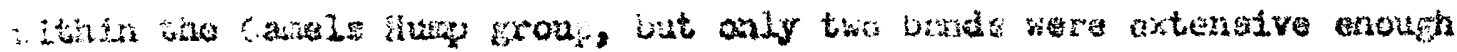

to show on the map. The lariegt of the de gonthost of lowen

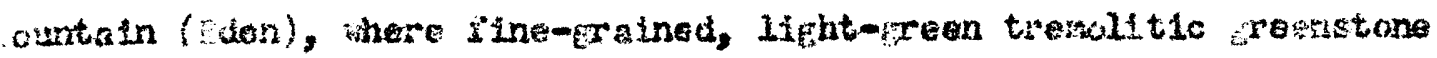

c.tops out in a band about 6,000 feet lons crom north to couth and sbout

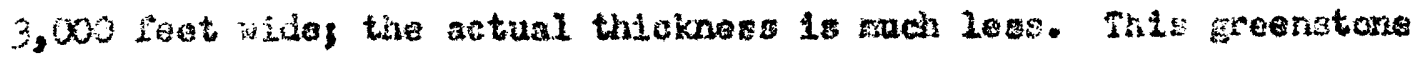

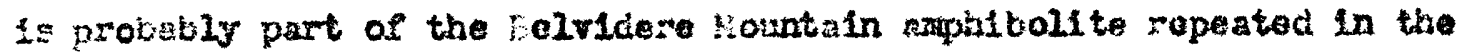

Hot Frook eymcline. The othar grenstone rapped is a bend af albite-

nangtite greenstone from 10 to 75 feet ulde, wich wat traced for

atout one nle both porth and wouth of rateran Srook (Jahnsan).

Severt sull mases of highly abltlo greanstone wero noted in

Whe alnite schist and gnelis reat of the Foot frcok area. Wheso rasces

rees to to diccontimaus, and are not confined to a singlo stratigraphle

2one. They are characterleed by high contunt of albite porphyo-

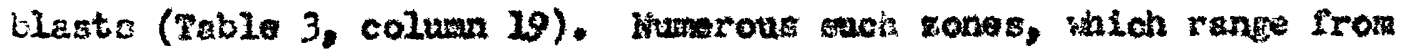

Lansos a fev feot wlde to bands sereral hundred foet wio, and whleh

co not form maprible units, erop out in tho brooks thet 12 ow east and northerst from the terling Rengo.

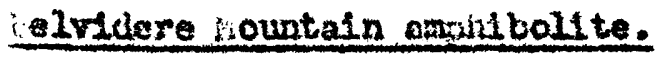

The nare lelvidere fountsin aroblboldte was introdked by keth

and in 1 (1932, p. 174) for the rocks exposed on bolvidere sountain

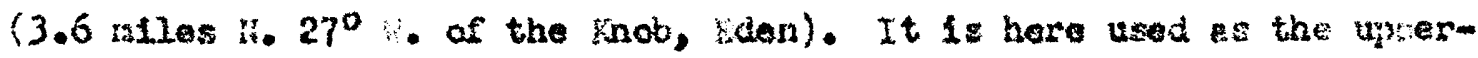

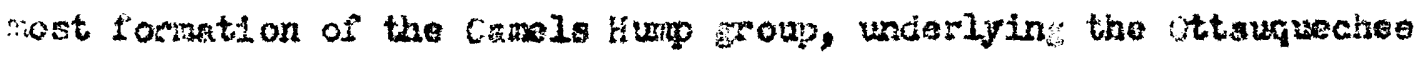

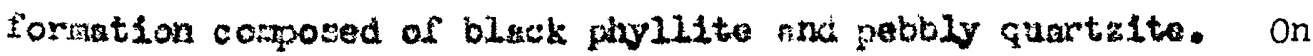


Selvldere hountain the axphibolfte is probaily 700 to 2,000 fot

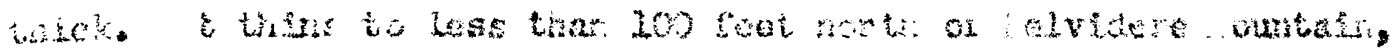

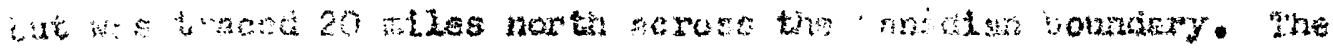

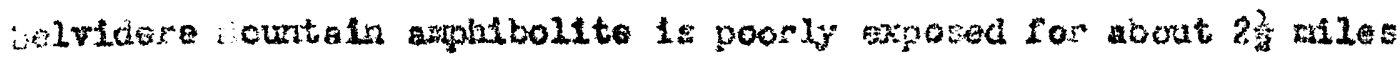
along the etrlike in the northonatera part of the liyad rerk quad-

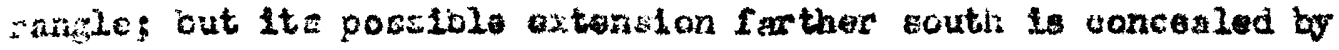

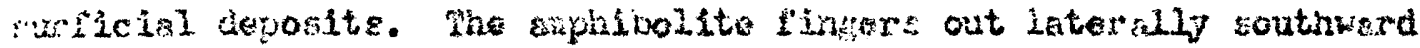

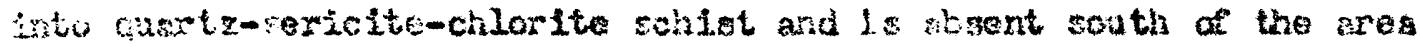

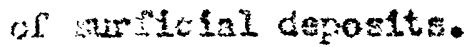

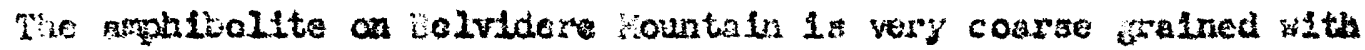

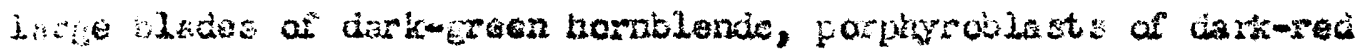

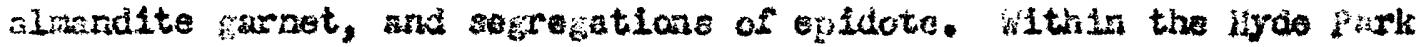

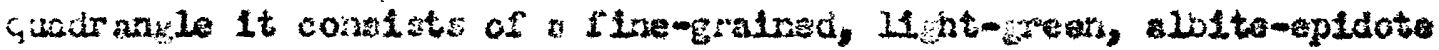

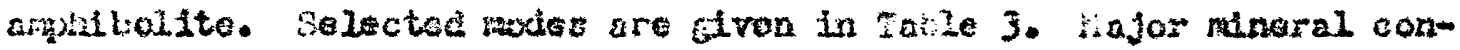
situentw are cplate, albita, ahloplte, and actinolitic hornblendes

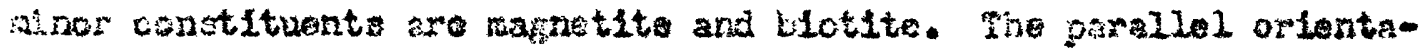

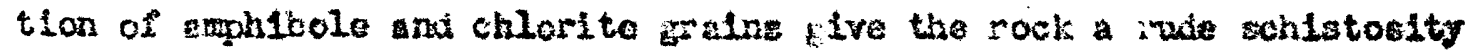
and oomposticnel layers parallel the echletosty.

The amplbollte $1 \mathrm{~s}$ belloved to have formed from water-1/1d iisfle volcanic dotritus. Eads of grapitic quartz-acricite-albite

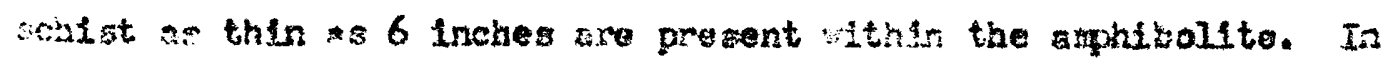
one outcrop tro guerteite bous, each shree-founts of an inch thlek, exterd for 20 fest parallel to the follation. The mag: ahous the Interbeding and abrupt trangltion alon strike frome emphitiolste 
Into graphitic quarty-albite-2orlcite and nongraphit1o quartz-soricito-

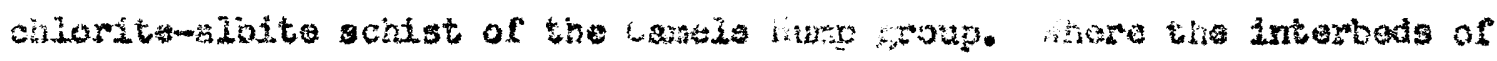

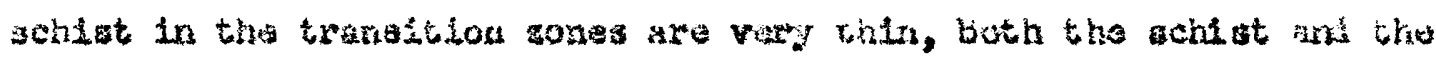
andibolite are $h \mathrm{~g}_{\mathrm{g}} \mathrm{hly}$ calcareous. Calcareous amphlbolite is counon at the north edgo of the quadrangle, and sraphitio anphibolste occura hale a mile farther north on the lower ast slopes of Eelvidere rountain.

\section{Staurueches formation}

\section{Goneral stationent.}

The Uttauquache fcrsation, flrst described by Perry (1929, p. 27) in the Ottauqueche id Irer valloy in southom Vernont, is characterized by rassive dark-gray quartalte and black graphit 1e quartz-sericite phyl11to and schist. It has bean traced noxthward to the liyde Fark quadrangle by Currier and Jahne (1941), Brece (1953), Oobarg (1952), and Cady (1956). Cady, A. H. Chidester, and the author have traced the Ottauqueahee north and aerce the Internstional Boundary into the Mansonville late" of Clark (1934, p. 21) in cuobes.

\section{Diatribution.}

The ottanqueahee formetion crope out in a noth-trending bund about one ante udde in the southern two-thirds of the quadrangle and in a band axtanding from the northeset carnor of the quadranele into the Upper Diggings (Eden). The latter band, wieb is $0.3-0.5$ wile wite in the Lppar D1ggings, ands a little northeast of Darls kill (hyde Fark). For soveral wlles the two bends of Ottawqueches are parallel and about two nilles apart. Thase bands are probably comnected through folds thet 
plunge southward beneath aurlolal deposit in the area botwoen liorth

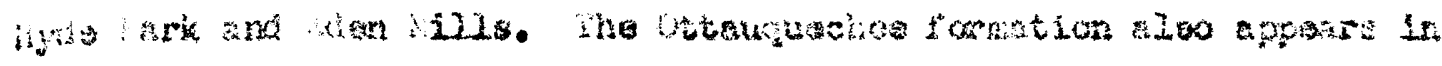

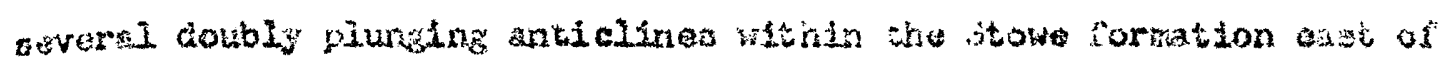
the rain belt of the Cttauquechoe, and whin a syncline, the Foot Brook syncline, in the Foot Brook aren weat of the main bolt of the ottauquechoe formetion.

sescription.

Solected modes are given in Table 4 . The Ottauquopos formation 13 charactarlaed by black grephitic quartz-sericite phylltte and schist and by asalve beds of dark-gray quartzite.

The ploylite cocmonly contains pyxite and weathers ruaty. The albito conteat is low and porphyroblasts of albite are rare. Altarnation of thin lagars of white quarts wth layers of graphite and sertatte in Nlakes oriented parallel to the layerine produce salotodty, probably a bedding schlstesity. $h$ wore prominent later sohistosity cuts ecross the earlicr one, and in many pleces totally obliterates it.

The quartalte is dark gray and composed almont entiraly of quarts with a little dieneminted sraphite rarely detritel graine can be die-

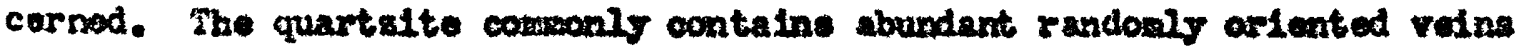
of white quarts. quartaite with thin, closely apeced partinge of sorc1te and chlorite; and soldtemautz-chlordte phyll1te also occur. The phyllite contains thin bede of 11 mostone in a few placos.

ivany cutcrops of the Ottauquecher formation cannot be distingulshed from those of the Camels trump group, but in general, the casels hurp contalns wore quartalt with glceceous parting, less bleck phyllito, and 


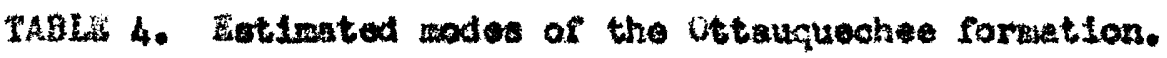

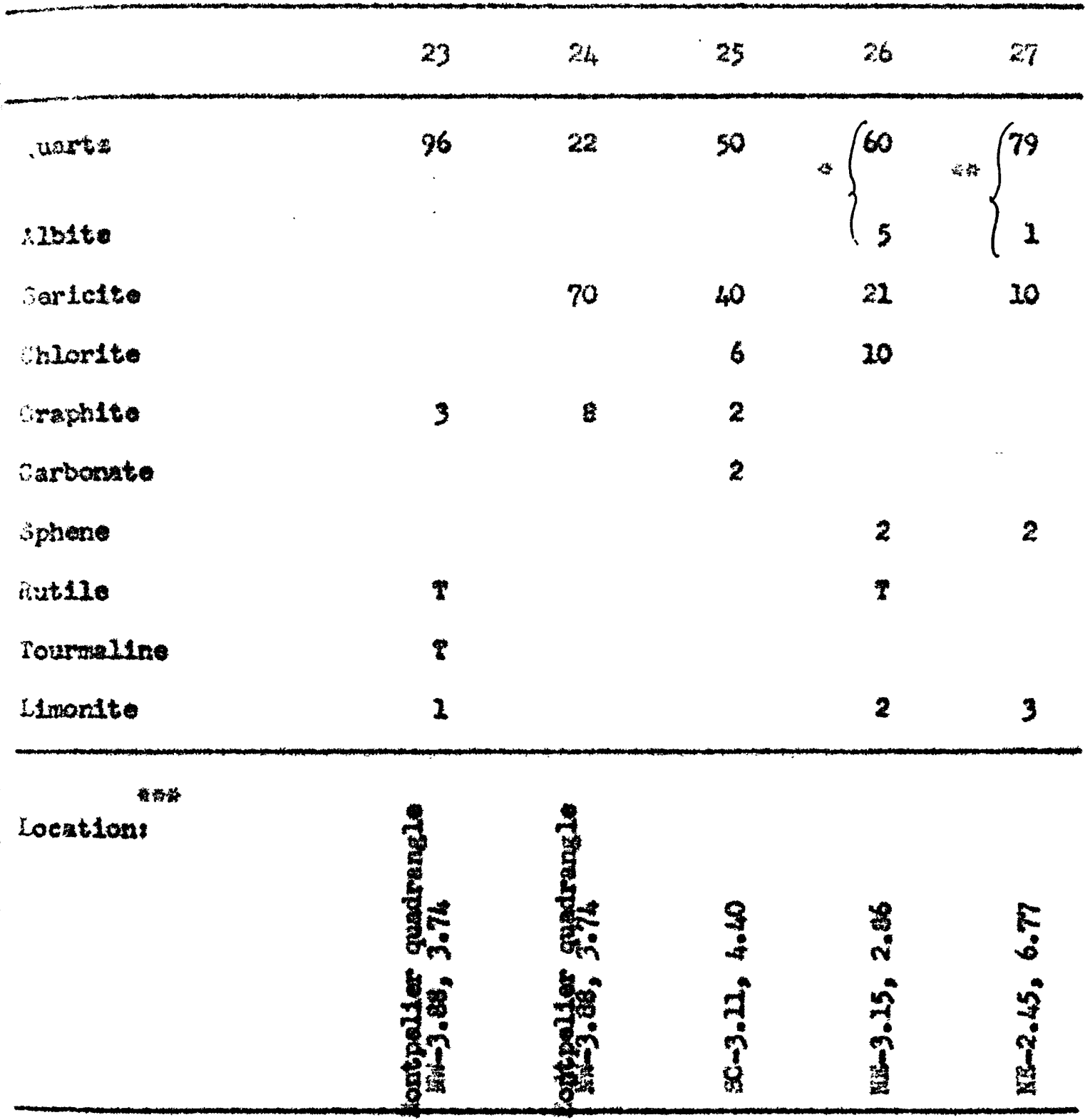

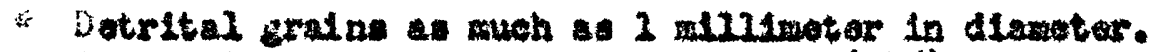

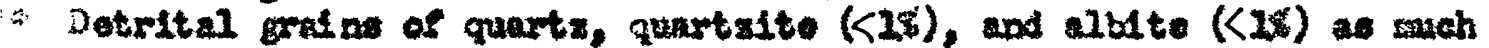

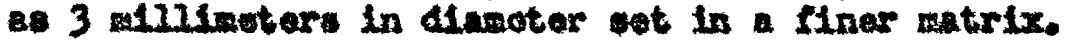

* * jolanation on page 5.

23. Hissalve dark-gxas goartzite.

-25. Craphitie quarte-serielto-ohlorit sehtat.

-2\%. varte-sericlte schist with coarse dotrltal gradn. 
Its schist appoars core quartsose and aror albit lo than that of the

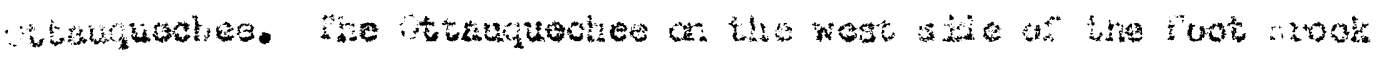

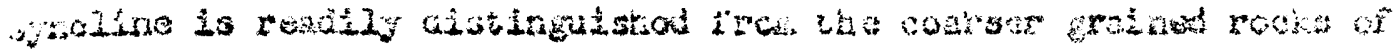

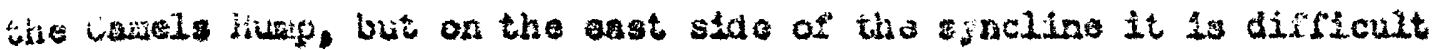
to distinguish one fron the other becsuse of the sinflarsty of the

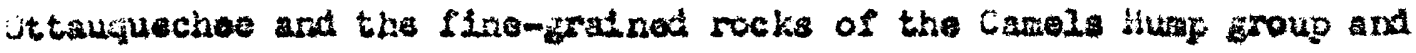
becruse of the pauclty of outcrop.

The ottauquechee forzation of the porthesetarn bend, north of the Upper DLggings Ineludes light-zray qustalte and quartz-anricito scilist cantain detrital graine of aranule and pobblo alve. Beds of the massive dark-fray quartalte erop out north of the ligde lark quadrengle. The detritel grains, wich are as largo as 6 millimeter, are prodoalnantly quarts, but sow are black stalo and fold spart the grains constitute as ach 2845 percent of the rock. Those of quarts are subrounded to subangular and sme undeformd. The coarser sizes are in beds with a highor pobble content. The watrix consitet of funrtz, seriolte, and chlorite, dth iron-bearing carbonate veathering out. North of the dyde Park quadrangle a yelloniah-brom quartzsericite sehist with enly anall percentige of grenules is comon; it is Introbeded with graphitio phrilite. The lithologto type is rot sbundant within the Hyde Park quadrangle.

Nocks of the northeastern band of ottanqueche are well exposad wost of routh Pond ( 5 den) and en a bl11 0.4 wilo couth-eoutheast of ion 1118. Rocks of the main band are rell axposed northwest of ilake Cenetery and east of idyd or izook (thorristonin). The contact of 
the ottauguecke formation with the undorlying Belvider fountain

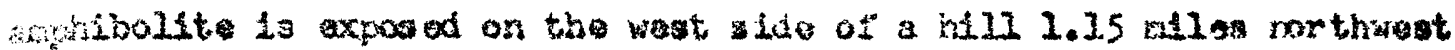

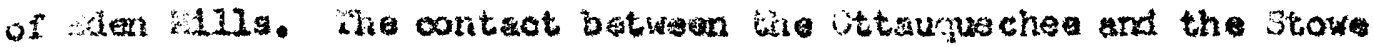
for ations is axpos at several places botwean Bearer Voadow Brook (higle Paxk) and s sanll hall 0.25 mile rorthwest of Blake Cenetory (tizde rark) and in nurarou places within tho Uppor Diggings. The itow faration insedstaly abova the cantact cont an a fow beds of Eraphitic phyllite and solst trat diffar from tiose of the Ottauquechas only in the leck of assoctated beds of quartalte.

\section{Stowe formation}

Ganeral staterient.

The stow formation (Cady, 1956) comprise "coht ats and thick Interbads of zpenztore and amghibolite, which are typleally developed In the soutbeastarn part of Stow towmip and adjotning axus." The narce Stowe foration replaces the Bethel schlat of Rlehrerdean (2924, p. 82-83) bocause the nue "Bothel" we preocenpled.

The stowe tormation is characterl zed by the predondnance of a ailvery-grsen, serleite-quarts-chlorite schi at with maerou lentioles of granular white quarts parallel to the ochiotosity (Plate 8). Bedded arpilbolite or reentone wmon throughout the stowe, and $r$ anse frow a foot to a thousand feet or wor in thickese. Although schists above and below the large nes of anphtboltt shoun on the map are slintlar, it 10 conrenient to deseribe the oeparat aly because the effects of alddlo-grade setamorphisa are conitined almost entiraly to the upper schist. Sstimated wodes are giren in rables 5, 6, and 7. 
F18ure 1. outorop of tpioal serlelte-gunte-chlorite schist of the stowe forantion. Wote the abundance of quar tz segragations. Abert 400 feet scuthweat of southweet corbor of collin Fond (ilyde park).

Pigure 2. Fpleal outirop of stowe sorntion in the root Brook area, 1.20 miles S. $65^{\circ} \mathrm{W}$. af the ste of navle neighborhood school (Johnson).

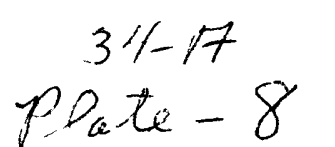




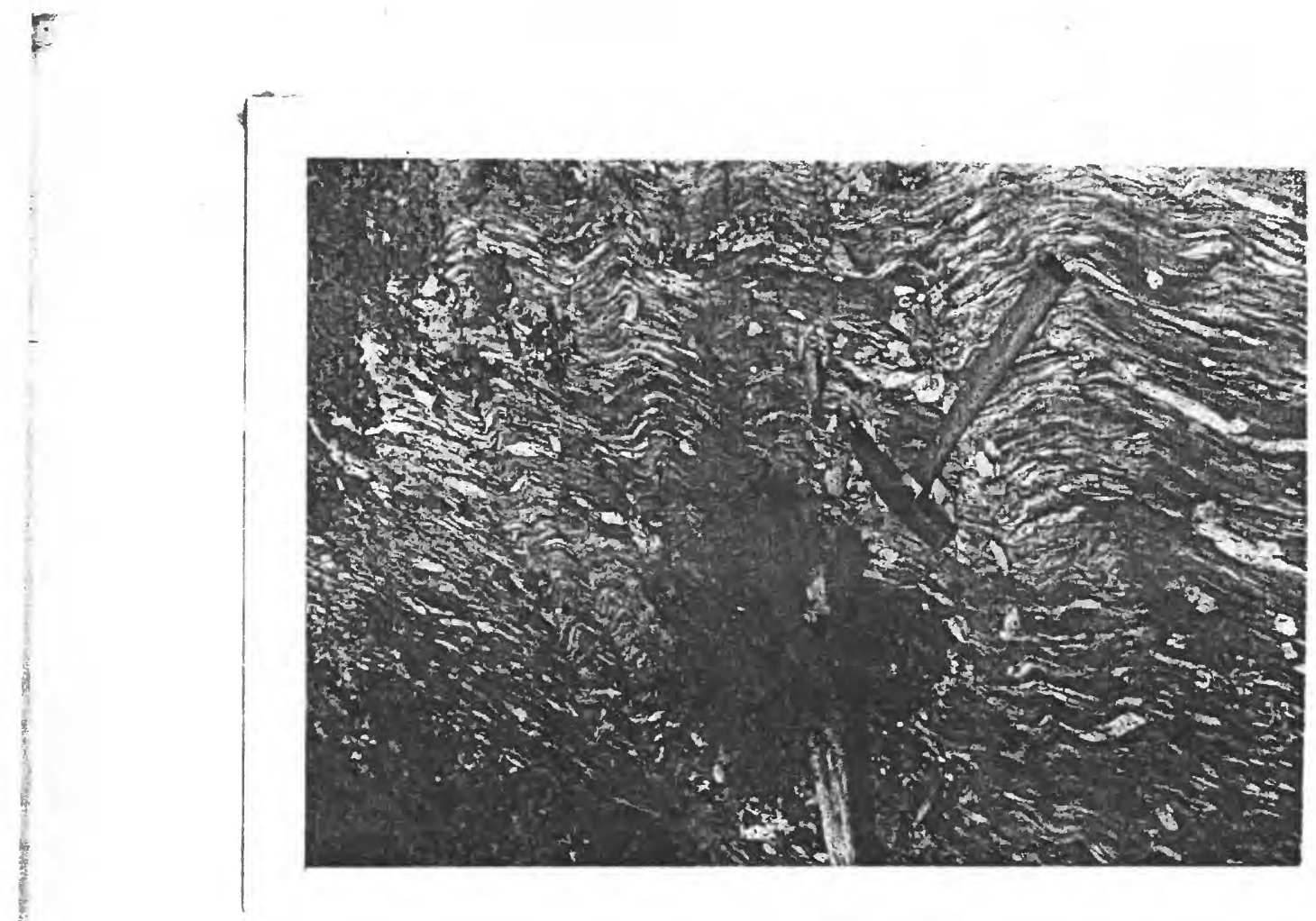

H.

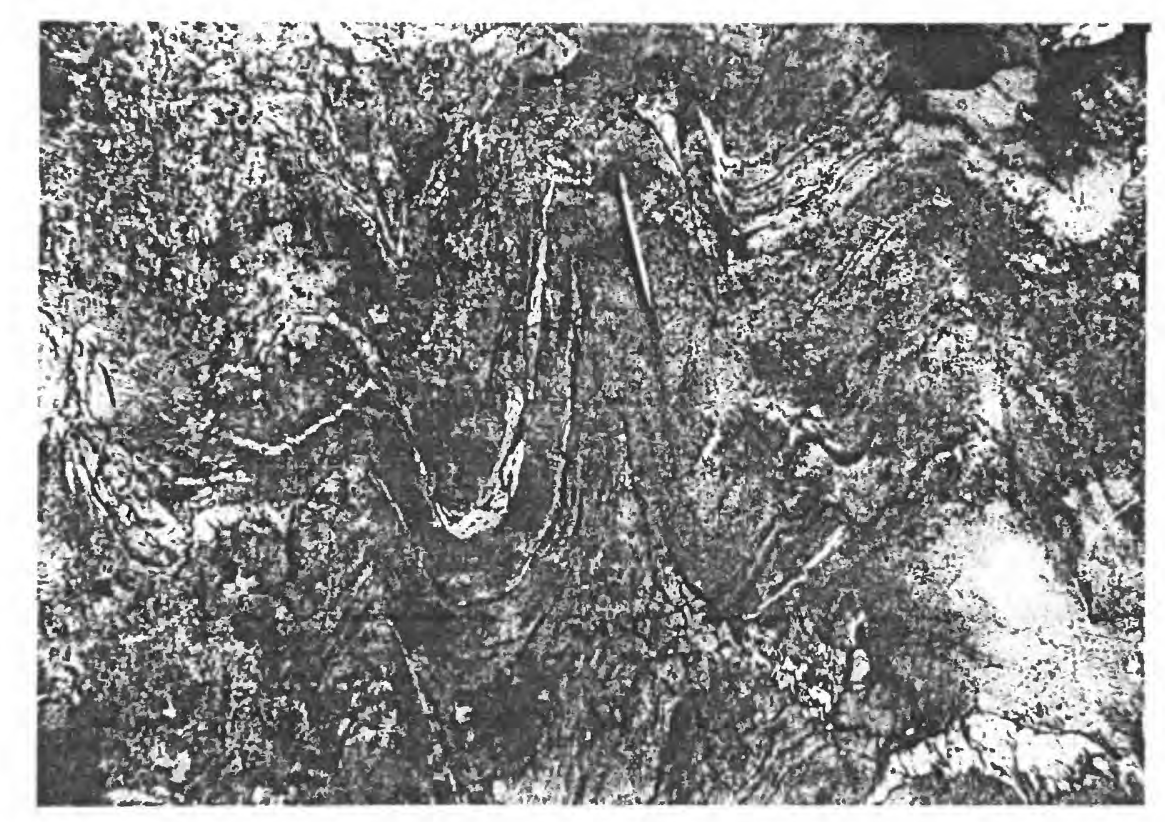

$\left.+1 x_{1}\right)^{2}$

Sate 8

346 
TABIE 5. Batimated nodes of the stow forestion - chlorite gone.

\begin{tabular}{|c|c|c|c|c|c|c|c|c|}
\hline & 35 & 36 & 37 & 36 & 39 & 40 & 42 & 42 \\
\hline wart & $\mathbf{1 5}$ & 12 & 50 & 40 & 20 & 25 & 35 & 30 \\
\hline $\left.\begin{array}{l}\text { iuscovit } \theta \\
\text { iaragontte }\end{array}\right\}$ & 44 & 23 & $\begin{array}{l}14 \\
16\end{array}$ & 5 & 13 & 50 & $\begin{array}{l}38 \\
12\end{array}$ & $\begin{array}{l}32 \\
8\end{array}$ \\
\hline Chlorite & 40 & 40 & 13 & 10 & & 5 & 8 & 22 \\
\hline Chzoriteld & & & & & 25 & 14 & 2 & 4 \\
\hline Albite & & 12 & & & & & & \\
\hline Fiagnetite & $\mathbf{T}$ & 8 & 3 & & & & & 1 \\
\hline Carbonate & & 2 & $<1$ & 35 & 50 & & & \\
\hline Limonite & & & & 10 & 2 & 3 & & $<1$ \\
\hline Sptdote group & $T$ & 2 & 1 & & & & & \\
\hline IInentte & 1 & & & & & & & \\
\hline Ruts 20 & & & 1 & & & 3 & 5 & -2 \\
\hline Eyrite & & & & & $<1$ & & & \\
\hline Tourmaline & $\mathbf{T}$ & & 1 & & & 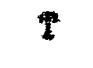 & t & \\
\hline Apatite & & & $<1$ & & & & $<1$ & $<1$ \\
\hline Loeation & $R^{\circ}$ & $\ddot{x}$ & in & $\frac{\dot{\theta}}{\dot{m}}$ & हैं & in & $\begin{array}{l}\text { if } \\
8 \\
0 \\
0\end{array}$ & $z$ \\
\hline
\end{tabular}

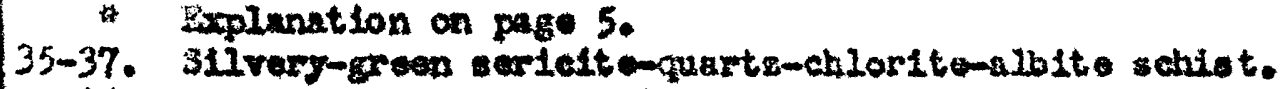

38. inkeritic quarti-seriest o-ohlorite schlet.

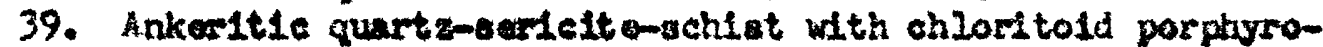
blaota.

40-42. jurtz-serialto-chlorite sohist with chloritoid porphyrom blasts. No. 42 from Foot-Brook symoline.
} 


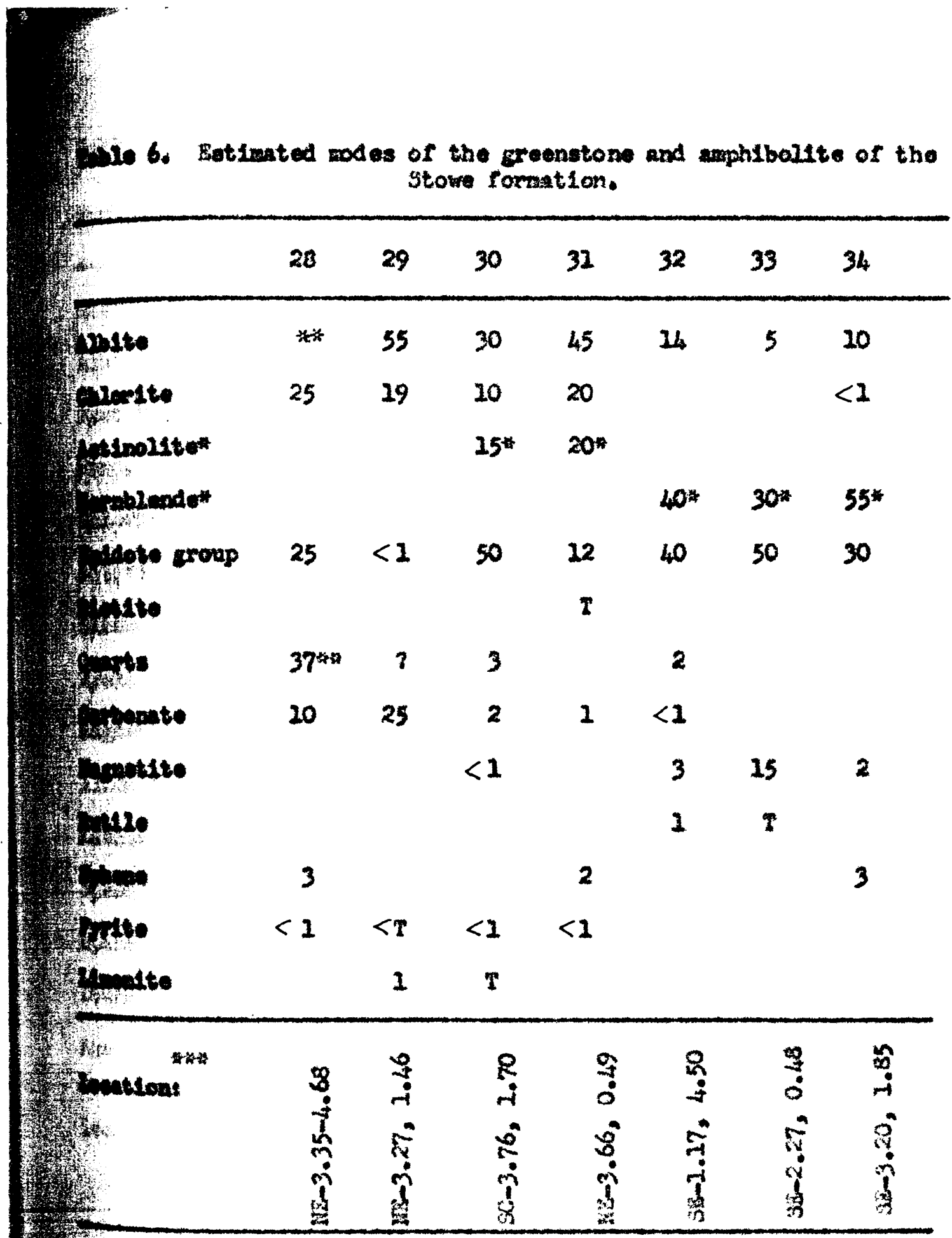

W. Wormblende if $\angle \wedge \circ=25^{\circ}$.

mevarta plus albite; quarta predominant.

*itioplaration on cage 5.

49. Ankerit1c greanstone from norther part of quadranglo.

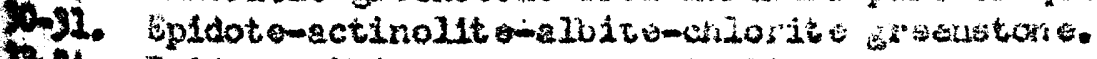

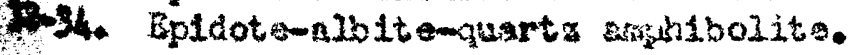


Table 7. Listimated codos of the stowe formetion - kyante and garnet zones.

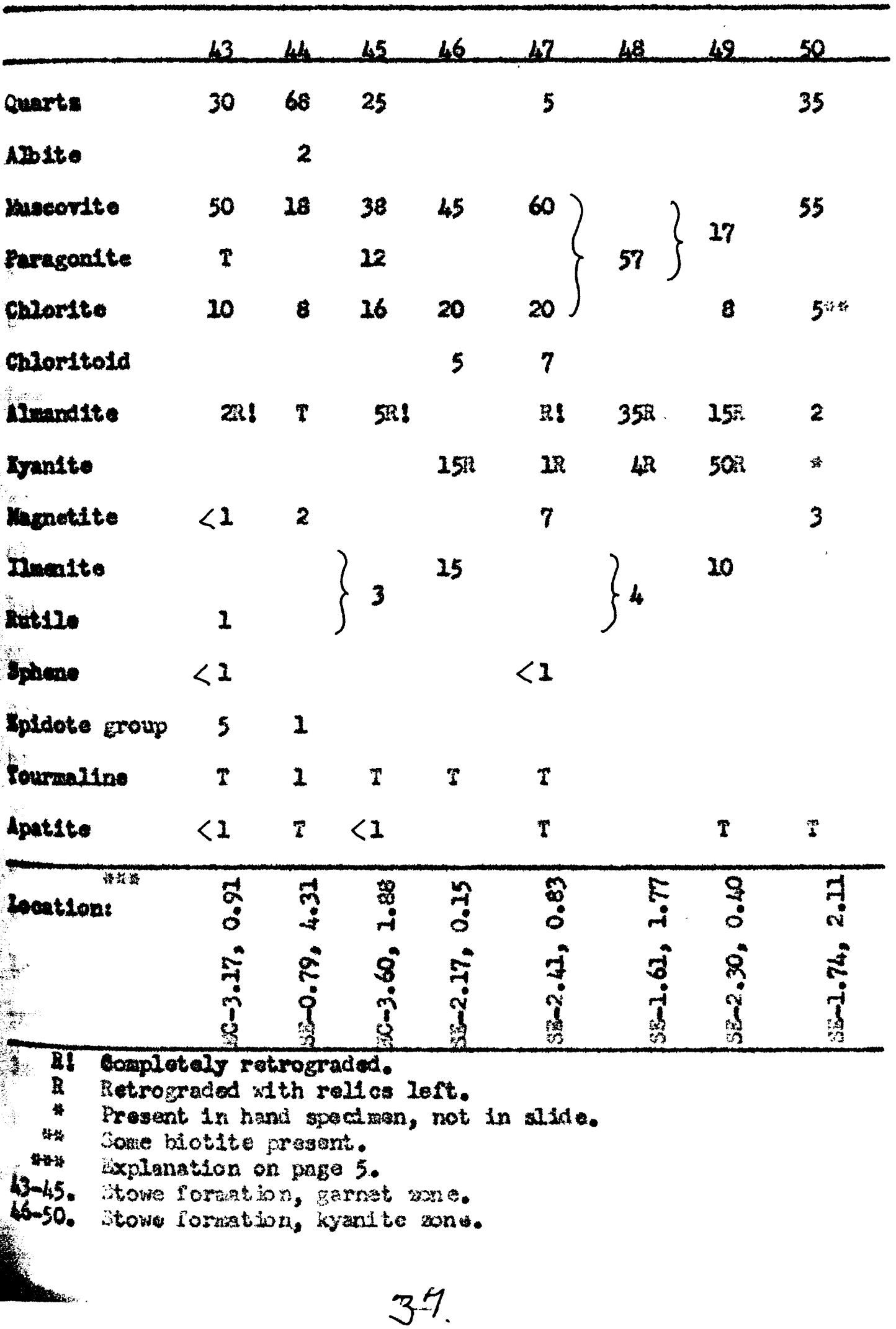


llorth of the ricintty of zack Hoods fond (hyde Park) the Stowe formation is oremialn to the east by the Umbrella Hill formation, conalsting of conglowerste and slate. Farther woth where the Umbrelia li111 famation is absent the Stow erates upmand into the Horetom formation by a decrease in the muber of quarts Iontieles and by the addition of the characturlatic "plastripe" schistosity of the haretorn. This gradational rone, soveral bundred feet acrose, is exposed about balf a mile eouth of the Lamolile Rirer.

\section{Iower ant athe}

The doainant rook bemoth the maln body of amphibolite is elno-

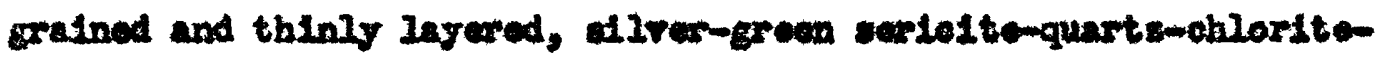

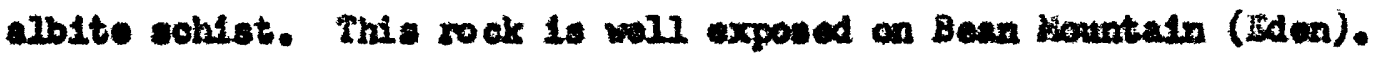
The acricite cont ent is gonerally grater than the quarts content if the guarts lenteles and reins aro aceluded if thoy are included the cerlolte and chlorite together generally axcoed the quets. The albite, comonly IIne grand, Is generally 10 se that 5 percent of the rook. Hagnetite octahedra are comwon. fecessory minerals inezude ruth1e, cartonate, imenite, ophene, 11wonite, clinosolulte-opidote, toureline, and aptite. The shlet cont alr quarts lenticles and

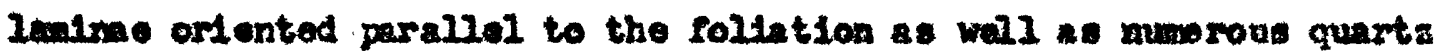
pode and ralne. Bodalng is rarely preacrod in thle rock, and the Ient1cles, lamine, pods, and relns of quarts are bellered to be segregation of quartz dorfved irom the sim rounding zocks. The segro-

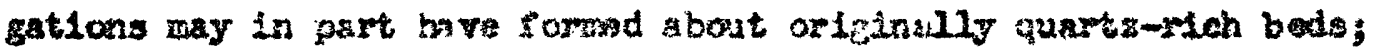


19y mald thw parallel bodding, bat would not actually be bodding. If

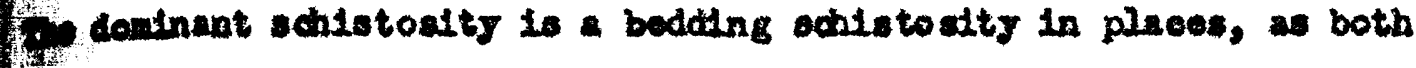
forlde of thin eections and fleld obsarvations have shom, but elsom now the dominant schlatositg cuts an earll or lollatlon. jome porCingobingts of albite intareect this late soblotosity and hence ownd after it.

Hinc-gralned, 11ght-oolored epidote-actinolite-alblte-chlorlte

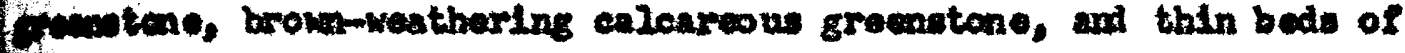

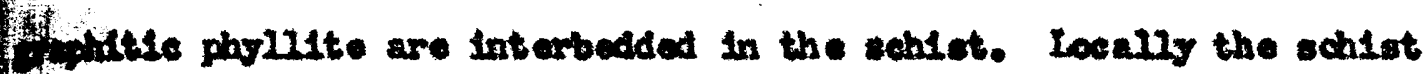

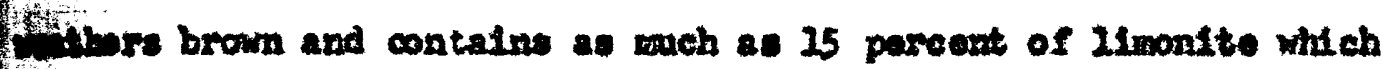
o Ifict to have alterod frem ankerite.

Wet of the north castern band of the Ottauqueches farmation in

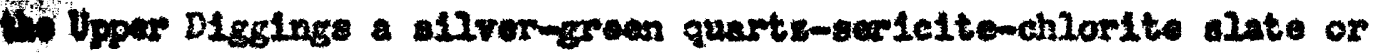
Whalite is abundant. Beding is poorly preserred and the slaty divige apparently generally cuts across the bedding. The alate or

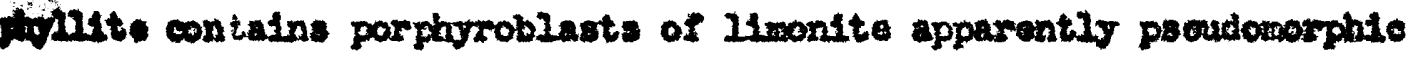
aric wagnetite, and $100 a 11 \mathrm{y}$ wenthors brown owing to the Itwonite and fribrite content. A few beds contain as unch as 15 pereent of tabular peigivoblasts of chloritola.

The basal part of the Stow farmation is wall exposed north of

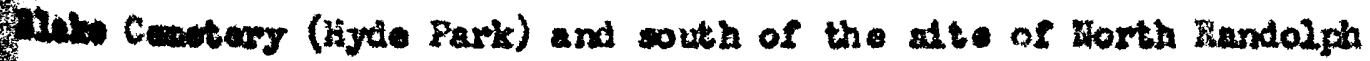
(5)

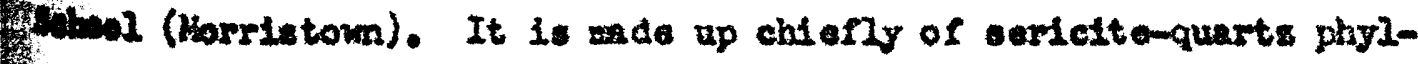
Wus, alatiar to that in the Uppar Digsings, and of black graphitic

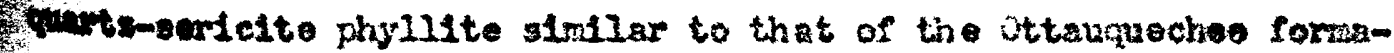

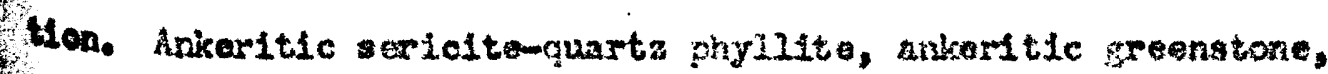


greenstone, and bods of Impure dolantte are comon. Impure dolontte, ankeritic quarts-sericite phyllite, graphitio phyllite, and ankeritic greenstone sre abundant from Clevaland Corners (Hyde lark) to about half a wle couth of the Inollle aiver. They are espoctally well exposed in kodusan Brook.

\section{Amphtbo24te and zremetone.}

The main as of amphibollte wuth of the Lamollle ifier and weat of ibluore Hountain is campond of a Ine-gralned, Ereenish-blnok, -pidote-albite-quarts amphibollte uth hornbleade noedles baralj vis1b2e to the unaided ere. Kagnotito is an abundent accessory binaral, and spheae and rut1le are comon. Salocted estimated nodes are prosented in Iable 6, colums 30-34. Although the anphibolite appoars madre, perallel oriantation of to mblende neodles and sove conpositonul layering, partleviarly of epldote and carbonete, produce a poorly developed follation. however, the rock does not split readily along this follation. Thin quarts lenticles parallel to the foliation are falriy comen, and ane thin section of the amphibolite contains 25 percent of quartz. sizall poutstic ageregates of albite, hornblende, epldote, and quartz ware probebly derived frow the surroundIng rook during metmorphism. The origin of large irrezular petches wth a high content of eplate is not known, but mo be the realt of oridnal differmces in composition rathor than of metamorphic agregatlon. This idophlbolit 13 woll exposed at numerous points along the shore rountin road. 
3ost of the asuphibolite in the large area west and southwest of il-

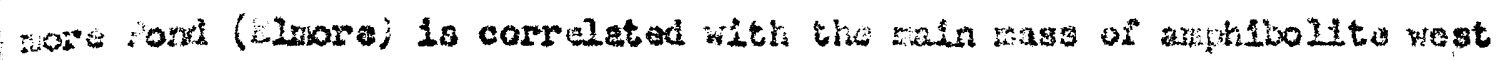

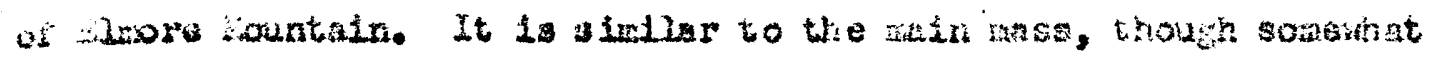
coarser grainad. Anphibollte beds as auch as 100 foet thl ck aro rathor cornon in the upper achlat of the Stowe on bivere fiountatn and south of Livore fond. Howe of this area is whthin the kyanite wone, and the ampiltbolit is coarme grained with stubby horriblende biedes as much os 4 rillimotars across. Camet porphyroblasts as meb es 10 millineters in disueter ware noted at a contact botween asphibolite axd schist. Pegentitic agaregates of albite, hormblende, and epidote are nore abundant, cosrser grained, and larger than in the mein amphibolite mass. Forth of the lawollle Rirur the anphibolite is a Inemgrained,

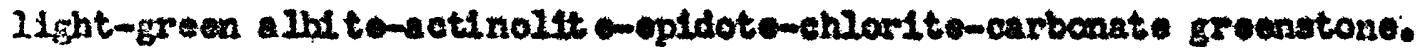
Table 6, colums 24-29, contaln selected, ostlated sodes of this rook. Actinolite necdlos are flne grained, and in places are not apparent to tho unatded eyo. The earbonete ontent is higher than in the amphiboItte, and there are numorcas intarbeds of highly ankeritlo groonstone and of ankaritie, graphitic quartimealcite phyllite. These rock types are well exposed above and balow the Garfle $1 \mathrm{~d}$ Dan, 0.7 mile northeat of [av1. Hi1] (eleration 1,140 an Green Rirer, Hyde Park).

The protolith, or prenotancrinte parent, of the anphibolste and eroenstone was probably water-laid nafle roleante dotritus adulterated With other sedimentary material, and the compos 1tlond leyaring probebly ropresents bedding. The compoeltional layering is comroniy parallel to boidlng in adjacent sohlet, to the contact with the sch16t, and to thin 
schist interbed within the greenstone or asphibolite. Sven where the doningnt schistosity in the achlat is not parallel to its batding on inmore tountaln, the follation in the amphibolit compony paraliels tho bodaing.

Upier gelist.

forth of Hyde Pond (Hyde Park) the rock above the maln rass of anFhifoolite ia siallar to the lower schlat. Yallowlah-gray veathering, fina-grained, and thinly layorod aerieltemquartsmchlorite-aibite schist prodorinates. This grades into brown-wothering, ankeritic serieltequartz phyllite, many beds of wheb contain abundact porphyroblasts of chloritoid. Albits porphyroblabte are losally abundant, but do not seen to bo as widenpread as in the lower schlat. Albite and chloritold have pot bear noted together. Humerous interbeds consist of rustymenthering, patciliy graphit1c and ankerit1c, erielte-quarte phyllite with porphypoblasts of pyrite. Thin quarts lertieles locally reseable pebbles. ctinolitic groenstone and greantone high in oarbonate are comon. The schist north of Kyde Pand (hyde Park) is fine-gralned and conlains chlorite and chloriteld, but wo gannet. South of kyde Pond the chilat It wuch coarear grelned, and at the south border of the quadrangle uscovite plates aro $\mathrm{as}$ mon as 10 millinetere acrosas garnet dodecaherons reach 8 millimetors. Carnot and chlorito aggregates, paeudoworphic frtor garnat, occur a little oouth of hyde Pond and becase nore abundant o the south. Kyandt occurs from the north end of sinore hountsin south pto the fontpolior quadranglo. 
The minoral asaerblages noted in the chist of the Stowo fortation

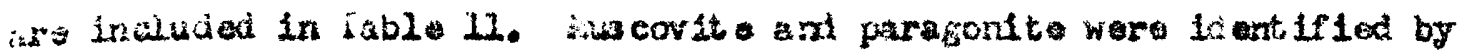

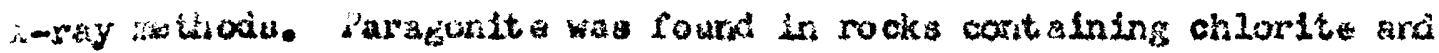
chloritold, but not in tho containing garnot ard kgand to. In the 2atter the mascovite probably contalns a mbstantisl amount of sodiven.

In the chlorito- and chloritold-bearing rocks ganteite and certonate are the abundant accesacy ainorals, and opiloto-cinozoisito, mt110,17enite, 11monite, tourmaline, and apatite are comson. In the garnot- and kyanlto-bearing rocks gnot1te, rut1le, and ilmonite, are sburdant; sphene, tourneline, apat1te, and sllanite are comon.

The DneralogJ of these rocks is complicated by the partial alteration of kyanite, garnt, and blotite to alnerals charecteristic of a lower tamorphic grade. Thus, hyanite is partly ropleced by finosrained muscovite (Identifled by $X-r a y$ athods) and chloritold, and garnet by chlexite and magetite. The rellet taxtures, the poeudotionphic replacenent of kyoulte by auscovite rather than pyropinyll1te, and the known pro-grade nineral asserblages in adjacent areas aggent that the

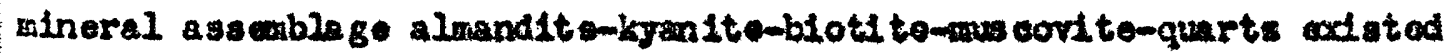
In the senlat before the retrograde altertion.

In the kyant te wa partly altered porptyroblasts of garnet and kyante respectively form as anch as 35 percent and 50 percent of the rock. Lonticlos and Irrogular shaped mases of coarwely erystalline quarta are abundsit. These seen to bave been sogregeted from the surrounding rocks, and thin sections from locelitios in tho kyartite wone Where juartz lenticles and asses are especially abundent show that the 


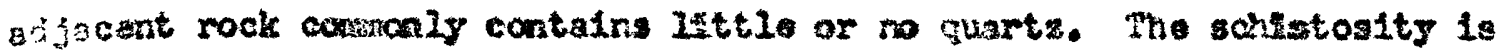

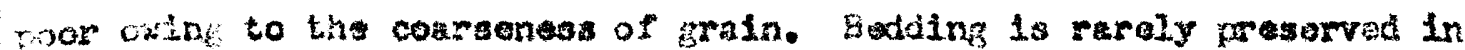

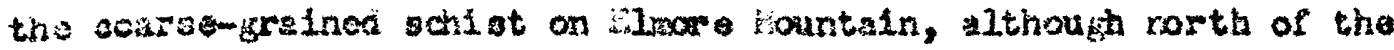
Lanollle itver compastional layering corranis indicate the bedding. However, the attitude of bedding is lndicated in many places by the contact botwen caarse-grelned anghibolite and schlst intwoeds.

\section{ich1 at in the Eoot Brook aroa.}

She rock of the stowe formation axposed in a ayrciline In the foot Erook area, the root Brook syaline, is predoninantly Ine-grafned iuartz-serioite-chlorite schi ot with interbods of grajiltic quartssar1cite-chlorite ochist and phyllite. Ureonstone and lapure caicite rarble also occur. The quartz-aerieltomchlorite soilst has a high sericits content (both muscorite and paragonitu) and a in wathering sivermegren apparance (Flate 8). It 1 g generally non-albitic, but thin beds containing porpinroblasts of albite are preseat. FIne-grainod chlorttold porphyroblasts occur locally throughout the stowe formation In tint area. Kagnot1te octabedre aro very aburdant; sowe beds contain

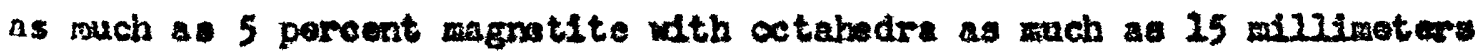
across. Porphyroblasts of pyrd to oecur in wo beds end aro abundant in the krephitic interbeds. Tourwalino, apat1to, rutile, and 1lemito are coinison accessory incrale. The shlet contains numbrous thin suartz lenses, and comeonit bas wall-deraloped slip cleavage and orinkles. uartalt beds are sbeent in both the quartz-saricltomohlorite schist and the graphitic schiot. 
sha graphitic solist and phylitt is highly meaceous, thinly foll-

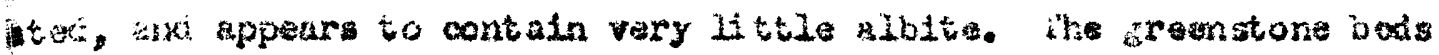

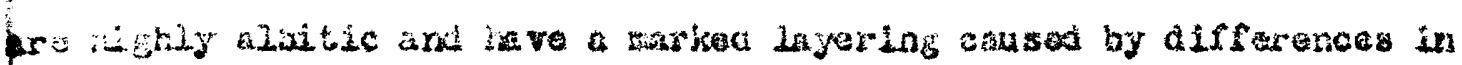
ibite cantent. A thin eaction from the band of grenstcre sbown on the fep conteins wore than 75 percent alsite. Soth the quartz-seriatioEhiorlte schist and the graphitic phyllite are well exposed in the eliffs p.55 eilia esst of the sit of kiversite Sctiool (Johnson) and in the uppar

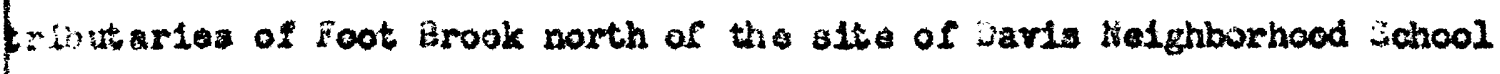
(johreon).

This area of quartz-sericito-chlorite ochist is correlated with the towe farmation on tire bazis of general liwologie aimilarity (including the cotmon sppearance of chloritold and paragonite/. Wlse the borduring pone of non-albitic bleak phyiltte and guartalte which aparatea the quarts-gerieltomehiorite ochist from the aloitic achist and gnoiss of Whe Cameis Fintip gro up elosely reseables the Ottauquechoe formation, and

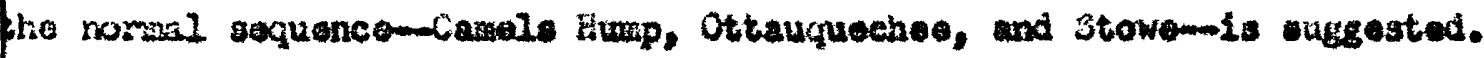
the quartz-sarictto-chloritomgatitomalbite sebiet bands of tho adjoinfor Camels thesp group are roudly distingulshable from the rocks of the towe forkition in tho goot Brook aren because they contain nuacrous Ficacesus quartzito beds and have a higher quartz and slbite content.

\section{Uimbrella lill formation}

Conglomerate and Interbedied alates, which are typlcally exposed on frd noar ymbrelle Hill (firde Park) along tho east-central worder of the parirengle are hore designated the bebrella illl formatlon. A swall 
F1gure 1. Gabrella HIII canglawate. Sigte framents outlined

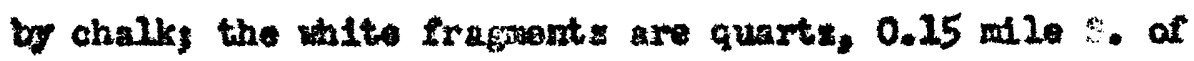
helght of land on Iden-Craftabury road, Hardwlok quadrangle.

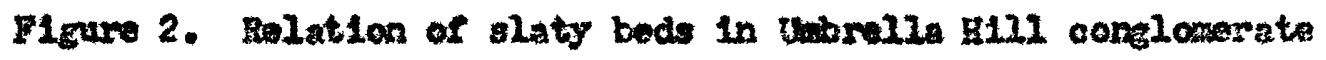
to sehistoalty. Contact botwen slate and conglonerato outlined with chalk. West alde of tobrolla HL11 (Hyde Pexik). 


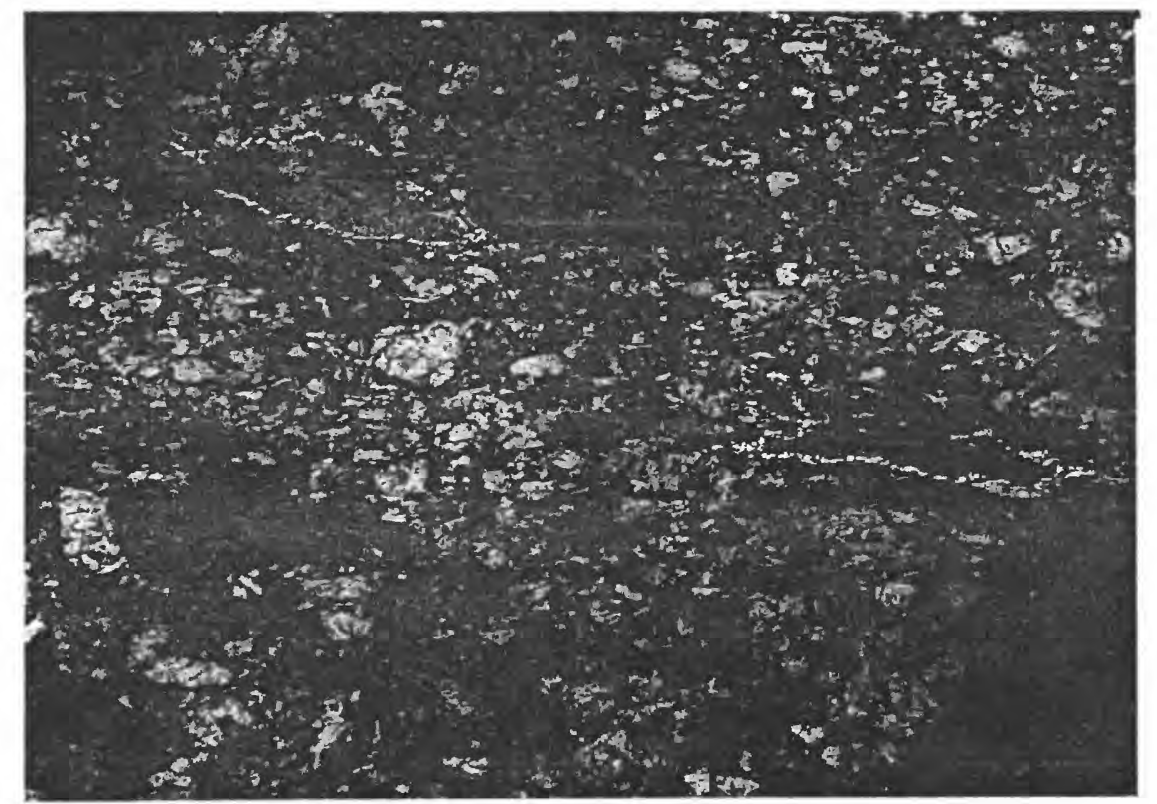

Prgure 1

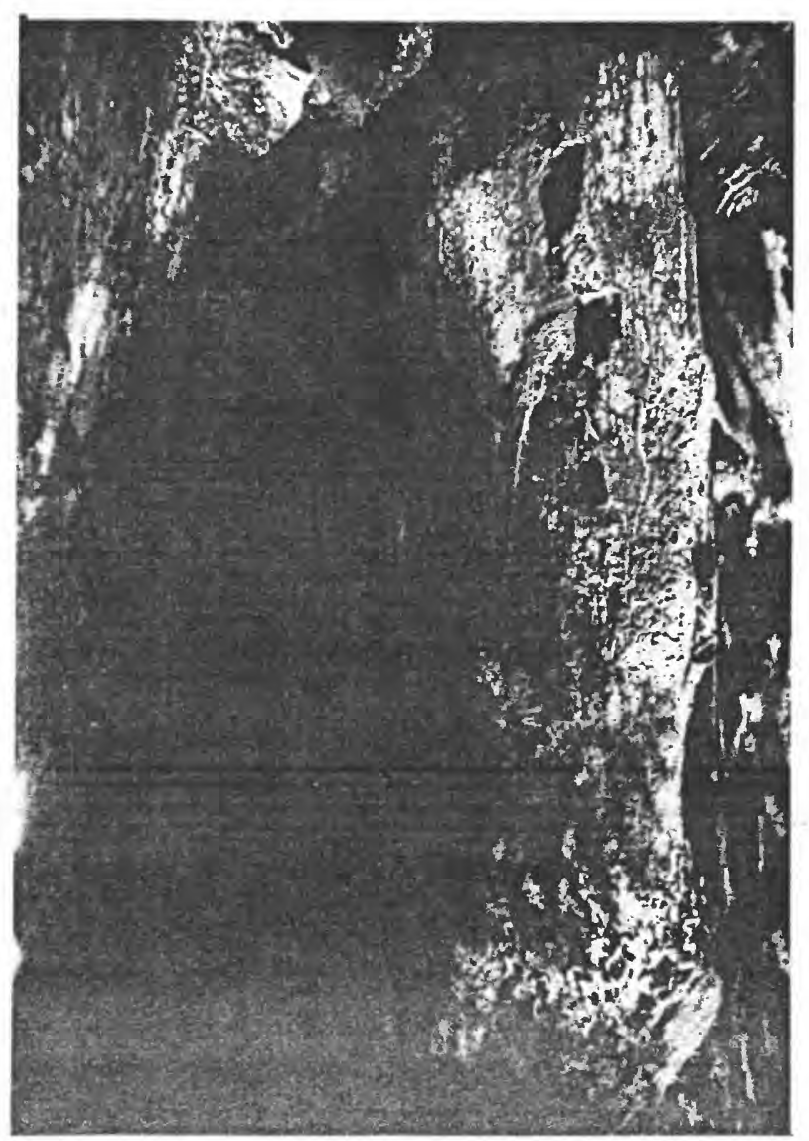

F Eutas 
Wasz of the conflowerate, whin is twolated in tight syncline down-

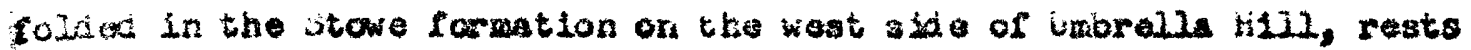
Fth angular unconformity upon diphikolste beds withtn the stowe. ifo unconforatty may be som at aevaral places. At ono of these, on the west side of the isolated was, rartionl bads of slate rithin the conglowerate atrike north. Twenty feet west lo an outcrop of axphibollte, the cospostional lajecing and foliation of wich strlke $N .50^{\circ} \mathrm{E}$ and Hip $44^{\circ}$ wit. this attitude 10 general over a conaldarable area. The Gndralla lill foration is orerlain, apparantly conformbly, by the yoretown farmation. The oonglawerate wa not been traoed eouth of the ricinity of lack woods fond. In the southern pert of the Hyde fark puadrangle and in the lontpall ar quadrangle (Cady, 2956) the stowe Cormation grades ppwand into the Korctom formation without apparent tratigrapht c break. The Uabrolla HLII formation is readily accesalble in the Handick quadrangle, 2.55 w110a south oast of Eden Milla, at the poligt of land on the roed from idea Hille to Craftibury. W. H. Cady nd the suthor here traced the conglomorato abeut 19 wiles to the northporthesst from the point ware it leaves the enet alde of the Hyde Park puadrangle. It appareatly thins to oxtinetion both to the north ard fouth. In sorarel pleces north of the hyde Fark quadrangle interbeds of preacione are present within the Uabrella ilill formtion, and the conporerato thins to extinetion in greenstono northward. 3ards of conglourate at the east and wast borders of the formation fre separated by a calcareous grey slate. The slate is poorly exposed,

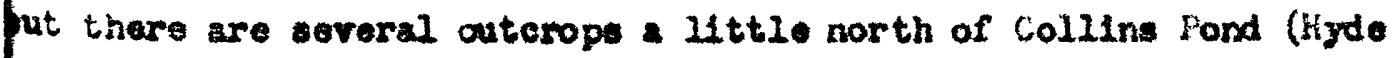


Tark). The eastern band of conglomarate thins southward to axtinction

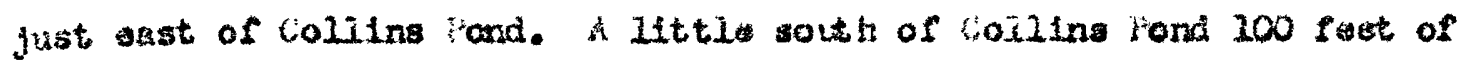
conlanerate are exposed in the wertarn band, but 0.75 allo farthor aroth it is only 4 feat wide.

Subrourded white quarta pobles are nost abundisnt in the conglowerato, but rod, yollow, an blue-grsy alat fregants are conan (plate 9. flgure 1). The largost pobbles in to at outeropo range 1 ros 2 to 3 inches in dLameter, but quartz pobbles as fuch as 5 inches in diemetar bavo been noted. The pobbles are undeformed. The matrix is composed of quarts, sericite (both macovite and paragonite in some apectmons) and rino-grained opacue alnerals; it ranges in color fres blue-grey to 11 ght tan. Porphyroblastso plates of greendsh-black chloritold, 2 to 3 w111meters in dianeter, are abundant in both the matrix and the olate pobbles. The overall chloritoid content seldom exceods 5 percent, but zuch of this Is concentrated in certain slate pobbles and in tin wones in the ratrix. Estimted moden are given in Tablo 8.

Thin beds of greeniab-yellow soricl te alate with a wat as 30 percont chloritold porphyroblasts are Interlaninated with the congloserate. ilaty cleavage cuts across color layering and sorvas thin pubbly beds In similar siate in the foolsted ss of the conglowarate on the vest slope of Uribrolla Hill (Plate 9, flgure 2). 


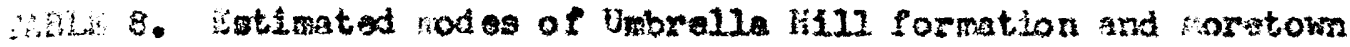
formation.

\begin{tabular}{|c|c|c|c|c|c|}
\hline & 51 & 52 & 53 & 54 & 55 \\
\hline uartz & 55 & 35 & 55 & $p$ & 75 \\
\hline ibite & & $7 \pm$ & 2 & & $\mathbf{r}$ \\
\hline Serictite & 35 & 45 & 25 & $P *$ & 19 \\
\hline Chlorite & & 5 & & * & 3 \\
\hline Chlortsold & 1 & & & & \\
\hline B1otite & & & 25 & & \\
\hline Zut 11e & & r & & P* & $\mathrm{T}$ \\
\hline Graphite & & $?$ & & & \\
\hline yagnetite & 9 & 8 & 3 & & $<1$ \\
\hline Ppidoto sroup & & & & & 2 \\
\hline rotwmallne & $\mathrm{r}$ & $<2$ & $x$ & & $T$ \\
\hline ipatite & & $\mathrm{T}$ & & & $x$ \\
\hline Linonite & & & & $p$ & \\
\hline iocationt & $\begin{array}{l}8 \\
\dot{8} \\
\text { n் } \\
0 \\
\vdots \\
\vdots\end{array}$ & $\begin{array}{l}\text { } \\
m \\
8 \\
8 \\
8 \\
8\end{array}$ & 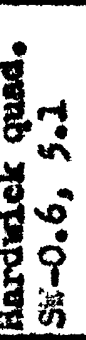 & 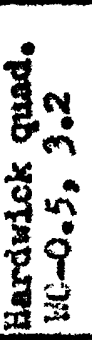 & 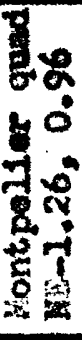 \\
\hline
\end{tabular}

* Too Ine grained to eotinate mode.

At it splanation on page 5.

51-52. Hatrix of Uubrolis Hill formation - quarts and albite are in part unrecrystellised detrital grains. uarts and alate fragsents are present in hand pecituns. Paragonite was found in 2 of 6 spectmons.

53-55. Cranulite from Norotom formation. 
Saretown formeton

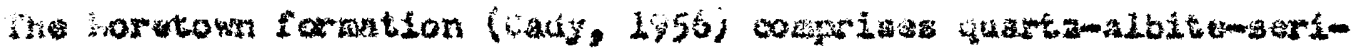

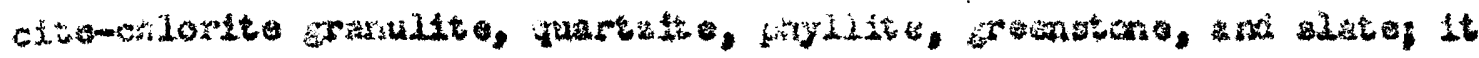
19 typteally exposid in eartem horetown towabip in tho sontpaller

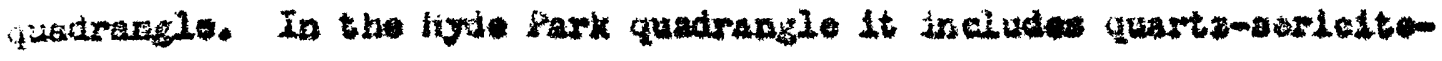

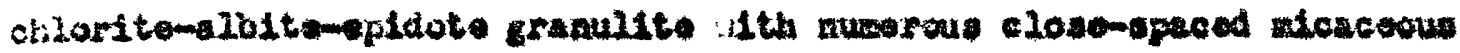

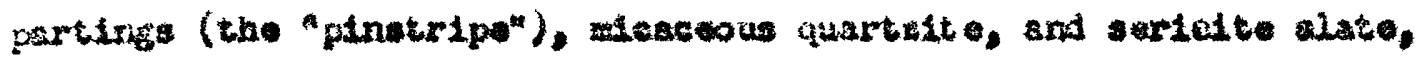

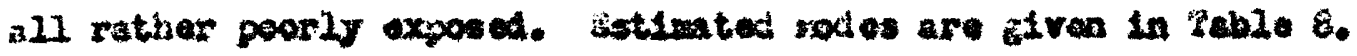
isose racks are all 11 ght

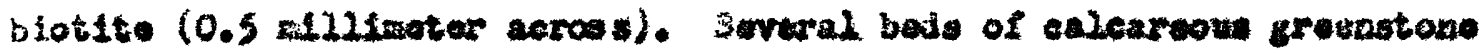

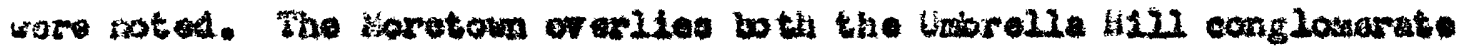

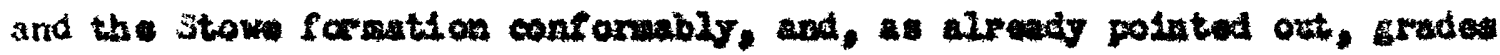
upran from the latter by Interlatintion. Dnly the lower part of the iroratown formation appoure wibin the Hyte fark quadrangle.

\section{Intrual re roek}

Serpentinte, tale-earbonate rock, and teatite

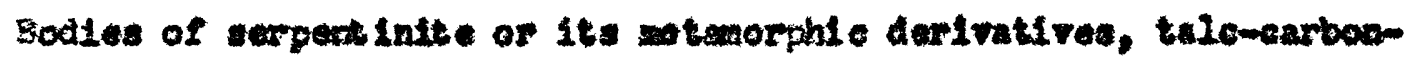

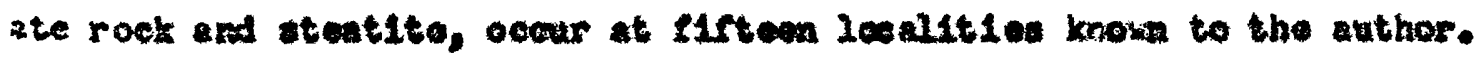

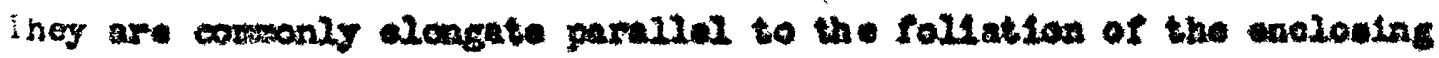

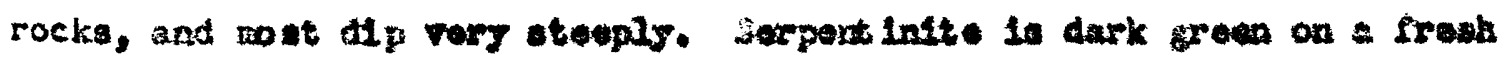

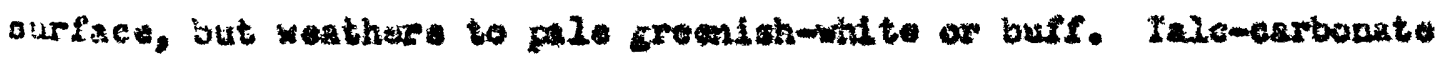

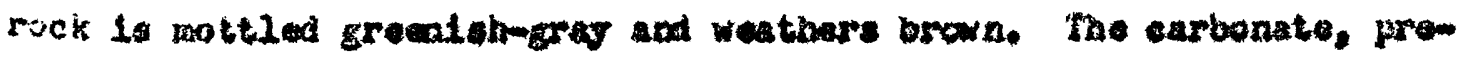

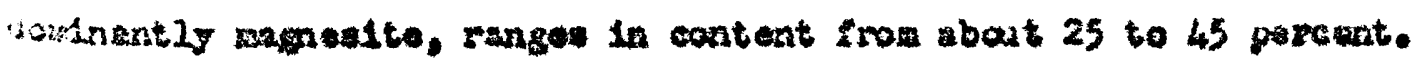

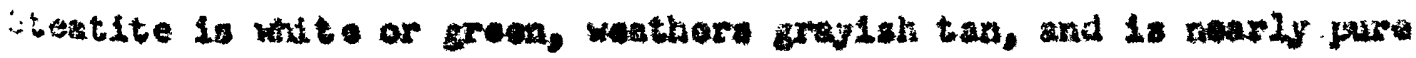




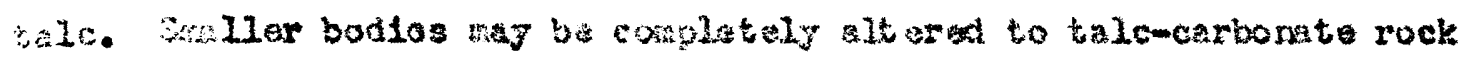
ani steatlts, but where in largor bod 1os the alteration is incouplete thlo-carbonato rock and stentlte forw successive outer zones. ine adjoining country rock ts alt ored to chlorite schiot called "blackwal." Serpentinite, or its derlvatives, or both were noted at the follow ing localities; those id th pasalbie econoule intarest will be deseribud in a later sectlon.

1) 1.15 1108 $6^{\circ} \mathrm{z}_{0}$ of the knob (aden).

2) 2.20 adles w. $48^{\circ} \mathrm{k}$. of the knob (itien).

3) 0.50 mile N. $40^{\circ}$ E. of the eumit of Howen Hountain (Eden) on Green sountain Club Frall.

4-9) Fithln area of greanstone show on anp southwest of Bowen Hountain (iden), throe exposed in brooks on sap, three exposed on ridges.

10-21) Tale Hine area (Johnson).

12) 1.20 miles N. $57^{\circ}$ is. of Chriaty School (Johnson).

13) 0.39 die $3.53^{\circ}$ k. of bridge orar Ianoille ittrum (Johnson 112age).

14) 0.27 mile $3.58^{\circ} \mathrm{k}$. of thed Drdige (Worriatoma).

15) $1.6 \mathrm{milea}$ H. $30^{\circ} \mathrm{W}$. of the Hnob (Eden).

\section{Lamprophyre dikes}

iwo dikes were noted within the lyjo Park quadrangls and one a ItttIs west of the quadrangle. The dikes are unmetamorphosed, unlike the rocics they intrude, and are comachly intruded into joint systems that 


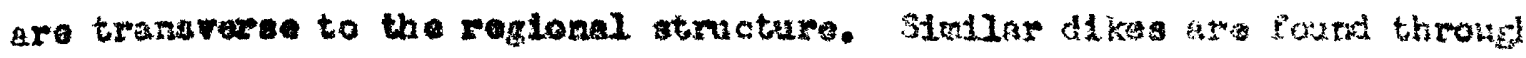

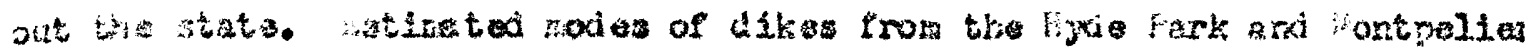
uaranglas are givon in toble $\%$

The rock io black and aphanit 1c. ihenocryats of hornblends, magnetit octahedra, and sgregates of anelofto and carbonato occur in sineurained groundoas of plagloclase feldspar and brown hormblende. The amphibole aens to bo an oxyhomblende near the comon harnblend and of tho sar103, wich indicates that those dikes should be claseffied as spessartites. 


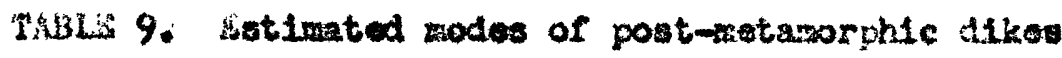

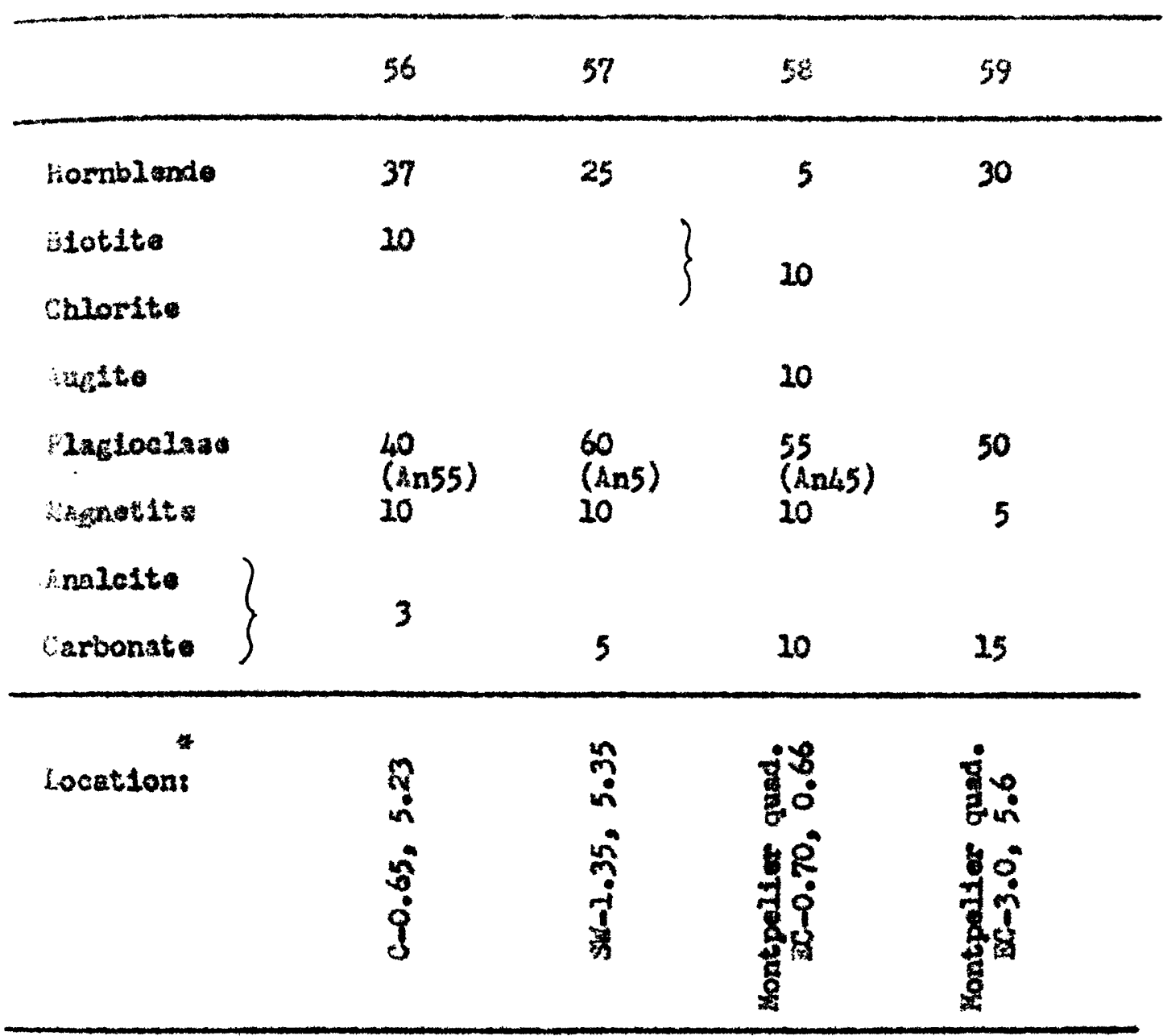

* Sxplanation on page 3.

56-57. Poat-motamorphie dikes from Hrde Park quadrangle.

58-59. Postmotamorphle dibas from tontpellor quatranglo. 


\section{STHW ivise}

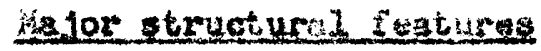

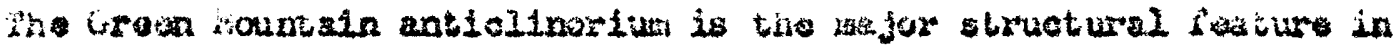
this area. Its axde erosees the extrane nor thwost cormer of the Hyile Tark quadranglo in a north-ropthessterly direction, but farther south, a little west of the aran, It trends more rortherly. The bedding a ifo gently os nt nar the crest of the anticliroriun, but steopens farther exstwand on the esst 1inb. The general east dip is reversed by a ramber of subsidiary anticlined (\$60 cross soctlong) that trend subparallal to ine min enticlinorial axis. There 18 ro ovidence far ajor faulting in the kjode Park quadrangle.

The general areal pattern of the rarlous mapplng unita Indicates brosd, shallow open folds, but, as discussed in the wettion an minor otructural features, waw of the winor structures fall to raflect the attitude of the axial planes or the open asture of the inger folds. The eross sectlons are inferred primarly fron the generel areal pattern. Liorthwest and rorth of Johnson v11lage part of the Ottanquecheo and jtowe fcrmations appear in the Foot arook ayncline where the aro fown-

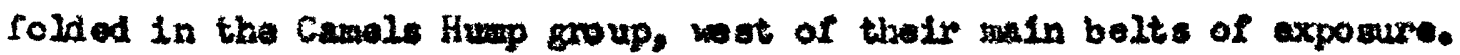
ihsse formtsons crop out in the Foot Erook symcline over an area about 11 miles long frat north to south and about three wly vides ther axtend northward into the Jay Poak quadrangle.

An sutleline must be present sast of Johnson v1llage between the root srook oynuline and the zadn belt of exposure of the Ottauquachoe forsition, but fts axps could rot be locatad. The discontinutty of the 


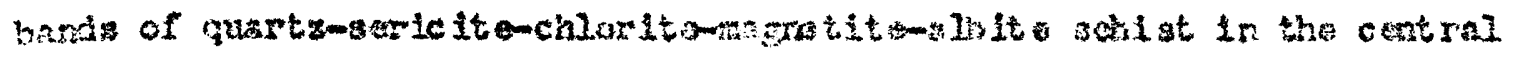

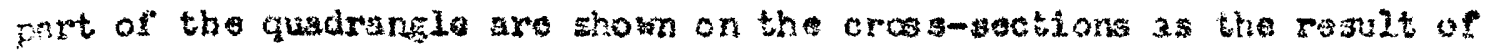

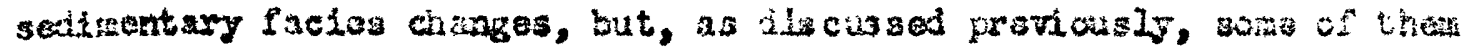
ray be isolated, domfolded aynelines.

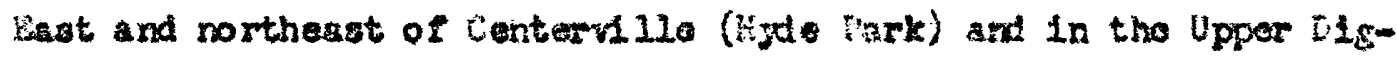
Einis sevarel folds aro shown by the pattara forme by the ottanqueneastowe contact. Those rolds just esst of Centarillo are doubly pluneine, Whereas those in the Uppor iligsings plingo gantly southward. Othar folds are anown by the pattern of the arghiboltte unit south of Garfield, and by minor structures southeast of Garfield. In the vicintey of Elaro Sountest sereral folde are show oy the pattern of the axphibolfte units. AIl of these rather oper folds have nearly horlzantal, north-south trandIng axes. Sintiar folds aro foun in the Kontpoller quadranglo and oven farther south, as wall as north of the Hyde Park quadrangle, along the trend of the Horthfle 2d, Worche ster, ard Lowell dountains.

\section{Hinor etrugtural fetures}

\section{Introduction}

The outerop pattern of the formation bouzdartes and a knowledge of

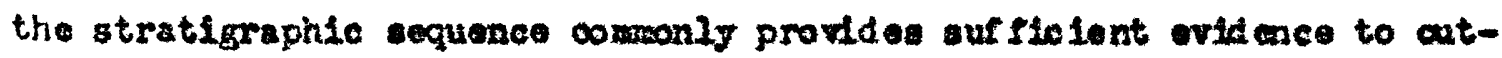
Ino the major atrotural fotures. Howorar, the zinor structural features are aloo of great Importance In understanding the nature of the hajor folds and the sequence of tectonte erents. These pinor structures Include planar and Inear features, hi ob aj bo obearved megascoptasily, ard taxtural features, such as rotstud porphyroblasts and iractured 
arains, witich my bo readily observed mleroscoplcally. Praferrod lattico oriuntation and profurred ainersiasial oriantation so alight that it

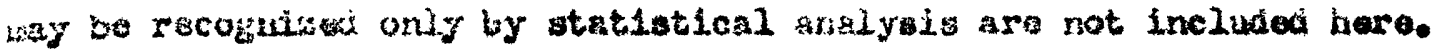
joth the charaction and the opatial relstiona of minor struturos are used in the flal interprotation.

fiogascoplc diroctional proporties of a rock my bo cutlinod as followe:

Flanar features (is planes)

1) Foferrad planar dimenstomn arientation of alongate, platy, or ellipsolital graine.

2) Honequant aggregatea of gratre, that 15, avering or lamination.

3) Erictures, Indepenteat of preferred planar dimenatonal orientation of gratina or grain aggregates.

4) Fractures and joints.

Lnear ceatures (Iineation)

1) Praforred Ilnear dimeneional orientation of alongte graino.

2) Mlongate agregates of graina.

3) Lines of interwection of planar fentures.

4) Fold axos.

The following festures are comonly resdily observable wloroscopically

1) Rotation of gratin maxked by holieal plinos of 1nolustons or by the oriantation of presoure shadow areund porphycoblasts (Hugge, 1930, p. 32, Faimbairn, 1949, p. 52-57).

2) Fractures and ctrain shadows in grains. 


\section{3) Cranulated rrain boundartes.}

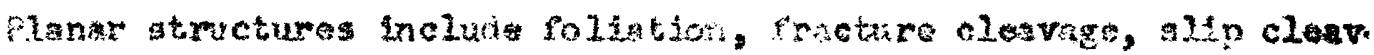

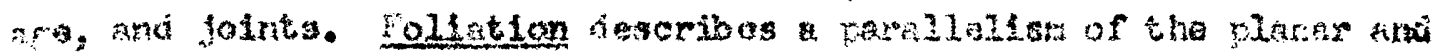
Iinear fabrio alemert of the rock, wich anabiss it to part along near It parallal planes. These fabric alerento inolude aggregates of grains In lonaes, pods, laminne, and Iayere os woll as individual nonoguant as aril grains. Tha uage of follation corresponde rather closely to the of Head (1940, p. 2009), Fairbuln, (1949, p. 5), Turner (1951, F. 559). i115ers, turner, and 0ilbert (1954, p. 169), 21111ngs (1954, p. 336), ard Kanp and Grout $(1940,5.222)$. Pelasarr follation ineludes bodding fis allity in sedinentary rocks and flow plen or layers in Igneous rocks; gecondare foliation Includes secondary lavering or Inafnation an schistosttg, as they are dofinod here. The angular rulationahip of socondary follation to primary lamination or follation ma bo expressed

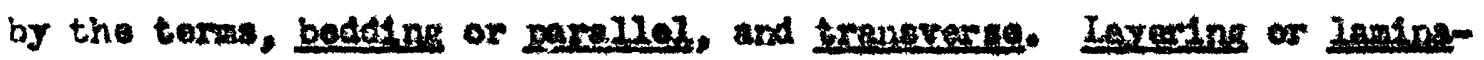
t1on, which may bo primary or secondary, describes a pariulelien of lajere distinguished by thet compaltion, texture, or colos. Sehfetogfty, though also ued for apolfle type of roliatlon, describes the parallel preforred ortentation of nonoquant ainerale. The perfection of a sohistousty, 1.0., the oxtent to wich nonoquat ainerels in parzllal proferred crientation make up or characterise the rock, depeni upon both the amount of nonequant minerals and the degree of preferred planar orlentation of these minerals. The torm flow cloarage has been ussd in wuch the same sonse by loith (1905, p. 12) and c200s (1937, p. 61). but othare (fatrbatrn, 1949, p. 239) ista ralsed objections to thi 
terme

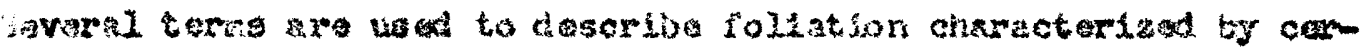

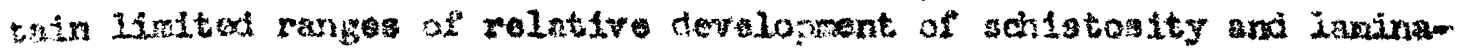
tion.

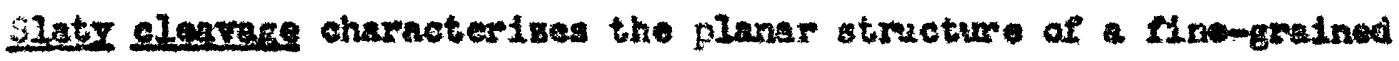
rook with good oohistosity, but ro of poor lamination.

Sehistogltx charactorises the planar structure of a fine- to sediungrained roek with good oulstosity ard poor to fair lamination.

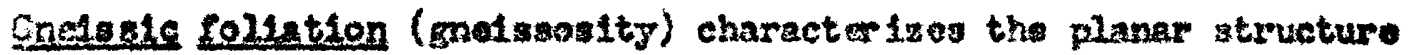

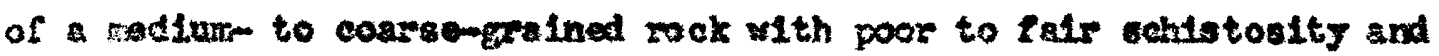
falr to good lazinstion.

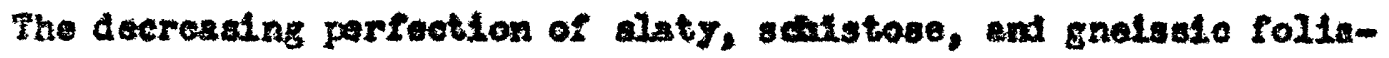
tion is due to larger gratn ise and to larger proportion of equant as cortparad to nonequent ulnerals.

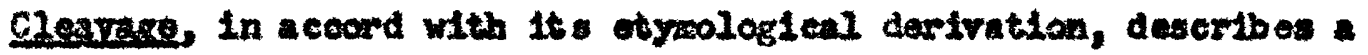
claaving of splitting-an actual parting surface. Iracture clearade. In accord with comon uage (B1Llings, Elth, 2923, p. 148) is osbentially a olosemspaced fracture or "noar-tracture" wieh 16 Indepondent of preferred planar orlentation of nonoguant minerals.

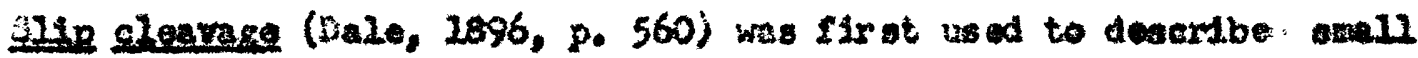

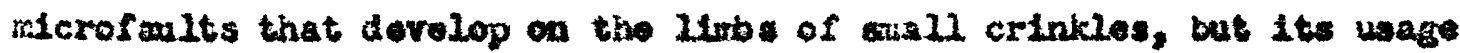
has ereciually boen actend to varbety of tranalts onal sturuotures.

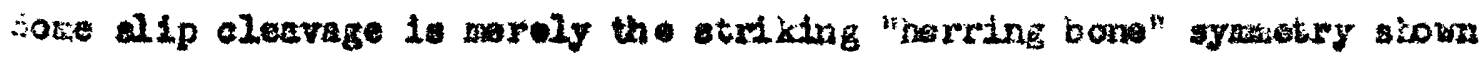
by tight crinkles in highly alcaceous no ck lligrod along parallol axtal planos; no ourface of discont Inuity by been although the rock will 
bosronly part. ho the crinkles bocows tifhter setual surfaces of shear aprear niong the thinned and alignad fole linbs of the folds. Comonly the first-formed sulaces aro discontinuous, fal a frotactul surfaces to tigit crinklee and back to actulal aun faces of discontimuity (fiate 13. (f1gure 2). In thi stage the slip cleavage cold actually be callod (racture cleavage excopt that, a pointed out by wht e (1949, p. 592), it Is questionable that the slp cleavge is entirely lndepondent of minereI orientation. With further dovelopwent platy minerals are present in the fourfaces, orlented parallel to thes. Somo gabistosity and slaty cleavage consits of ach surfaces, cloeely apaced, and containing aburiant platy Pinerala orlented parallal to the aurfaces; the ourfaces are separated by prests of cribkles in the earllor follstion. 341 olesrage 1 dependent apon the exiatence of an earlier follation for reeognition wore this to po obliterated closemspaced ellp cleavage would be deserib as a alaty or poinstore follation rather than alp clavege. Such a transition has peen deacribed by white (1949, p. 591).

Ihin layoring and ouffleient platy minerals so that alippage can oceur perallel to the surfaces of the lagers seen to be essentlal for the formaIon of close-apeced ellp eleavege. It asy be abeent in granoblastic hayers of a sch at and yet be cxtenstraly devaloped in adjacent micaceous. hayers. In fino-grained rocks $\mathrm{rlch}$ in micaceous ainorals the individual purfaces are snooth and contimuous, but in coarsar-grained rock thoy are quite irregular and discontimuous.

Folded planar structurea are a rerg userul otructural elent becase the pattem and opatial relation of a fold Ind ic ate the relatire rement 
sit the point of observation. The ettitude of an inglary plane tangent

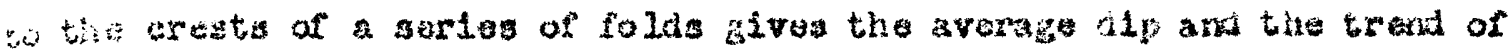

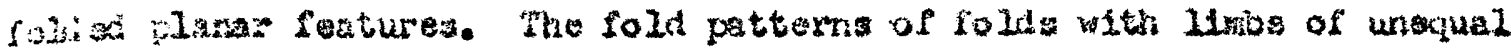
lergth are dlatingutshad as dextimal when they offset to the rifht in plan and sinistral wen they offact to the lert. A fold is neutrel when Ito Irros are of equal length.

Differences in the feomotry of lolds apoar to be closely related to If ferences in I1thology and hence to differences in campetency (see for axarple, Dale, 1896, p. 564; Thoupsen, 1950, p. 94, Osberg, 1952, p. 793 jrsce, 1953, p. 94). Th1ck-2ayered, nomeleacoous undts such as quartaite. form opan folds of largox wave length than do more weaceous, thinly laye ad schtstose unita. The echistore und s bore onell tight folds and way have a transverse echletosity parallel to the exdal plane of the wore ope folds in the quartzito. Horeover, folded mlceces u bede have ahmged ahe more than bre adjacut quartalte beds; the limos generally baing thimed with reapect to the crest of the rolds.

Character and apatial relations of uinor structures

\section{Goneral statement.}

Planar featurea shom on the pap (PIate 2) include bedding, varlous types of schistosity, and ilp cleavage; I racture olearag, saty clearag and joints, though not mappod, are present locally. Linear features ahor on the mp Include quartz rods, fold and crinkle axes, and the interseotIona of certain planar features; mineral all gnmant, streaks on the rollt tion surfaces, and longate quarts lonees, though not skom on the map, i cormisn. 
fithin the Hyde Park quadrangle Inoar and planar struoturas with

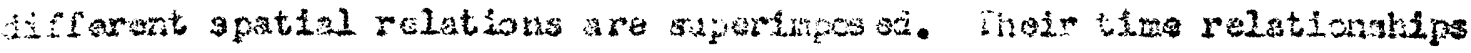

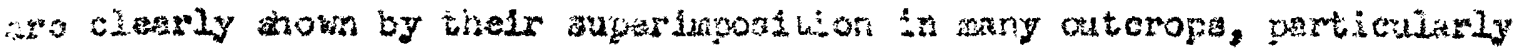

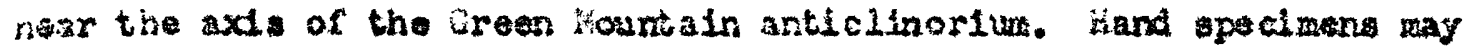
be found in whit on the axtal plane, axls, and limbs of an arrlier fold aro cloarly refolded about a fold axis nomily at rlght anglea to the oerllor fold axis. The later fold axes trend nearly north-oouth, subfarallal to the axis of the Grean Jountain anticlinoriua. Throughout wuch of the area the two sots of folos way be distinguiated by inference from their orlentation. It is convensent, and comon practice, when numerous atnor structures are descrtbod to indleate the planar structures as $s_{1}, s_{2}, 3_{3}, \ldots$ and the Linear features as $I_{2}, I_{2}, I_{3}, \ldots$, numbering thus in the probable onder of formstion.

In the lifde Park quadrangle the finor structures seen to have formed in the following orders

$\mathrm{s}_{1} \quad$ Bedding.

$3_{2}$ Secondary bedting foltstion and ecoudery compositional Iayrering.

I Ineations nearly at right angles to the axis of the Grean Mountain antiolinoriun; includes fold and crinkle axes; guartz rods, elongate quarta lonses, miraral alignwent, Interasction of $s_{2}$ and $s_{3}$ planes, atraiding on follation surface. Schistosity and fractura cleavage and $14 p$ clearage whit ch transects the oreste of $L_{1}$ fold. 
Lineations nearly parallal to the sxis of the oreen yountain anticlinorium; thcludes fold and crinkio axes, intersoctions of $\mathrm{S}_{4}$ planes with $\mathrm{s}_{3}$ planes. 311p clearage, saty cloarago, schistosity, fracture clear age (?).

$L_{3}(?)$ Near vertical fold axes and intersection of $s_{2}(?)$ planes with a fracture cleavage, $s_{5}(s)$.

$S_{5}(i)$ Practure cleavage.

$\mathrm{S}_{6}$ joints.

$s_{2}$ and $s_{2}$ planar Reatures.

Leflnite bedding $\left(s_{1}\right)$ in the form of quartzite bods, calcareous bods, and thick layers of distinetive eomposition may be sen throughout the liyde Park quadrangle (Flate 10, Agure 1). Thinner compositional and textural layering ean usuelly be attribut od to a primary origln in thi ares. Howorer, such layerlng has probably beon accentuated during

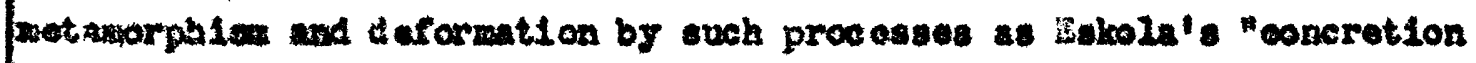
prinef ple" (Turner, 1948, p. 139). Loeal migration of meterial into lagers parallel to the follation sems to be reaponmible for the thin conformablo guartz lentiolos (Plate 10, rigare 2).

Throughout the ares both betding ant compositional layering parallal A schistosity $\left(\mathrm{S}_{2}\right)$ (Plate 20 , Fizure I; Flate 11 , Ilgure 2). The perfection of this bodding schlstosity deperds both upon the grain sise of the rook and upon the proportion of granular and micacoous ainarals. Creise and quartzlte have pooror schdstosity than schist, although 


\section{ixplanation to Flenare 2.}

1. Cohlstosity $\left(s_{2}\right)$ paxallel to quartsose beds $\left(s_{1}\right)$ and querta ogregations (shown in black).

2. Folded quartsose beds and quarte egregaticans fold axes ( $\left.I_{1}\right)$ plunge nearly down dip. mu or "sn-shaped rods aro forzed by shearine of strotahing out of fald linbs.

3. A Iineation $\left(I_{2}\right)$ formed by the intarsaction of quartzoat beds and quarts segregations vilth the ${ }^{3}$ sohistosthy suriace.

4. A schletosity $\left(s_{3}\right)$ wich tranceote orests of $\mathrm{h}_{2}$ folds and is

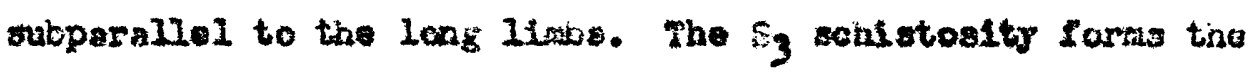
surface of the outorop becsuse of the ease vith whlch the schistosity parts.

5. Open falde and su 11 crlukles $\left(L_{2}\right)$ whioh fold $5_{2}$ and $\mathrm{s}_{3}$ schistositles and $i_{2}$ fold axes.

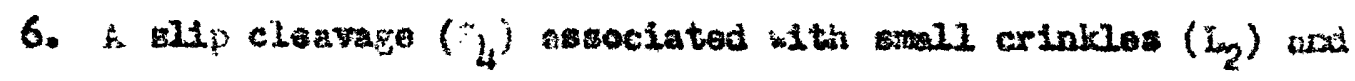
parallel to the axlal planes of the opan folds $\left(I_{2}\right)$.

7. A lineation $\left(I_{2}\right)$ formed by the intargection of ellp cleavage $(;)$ and schietosity $\left(E_{3}\right)$ 


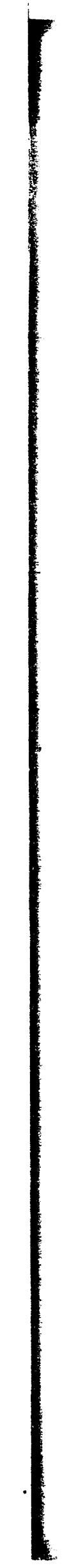

Figure 2

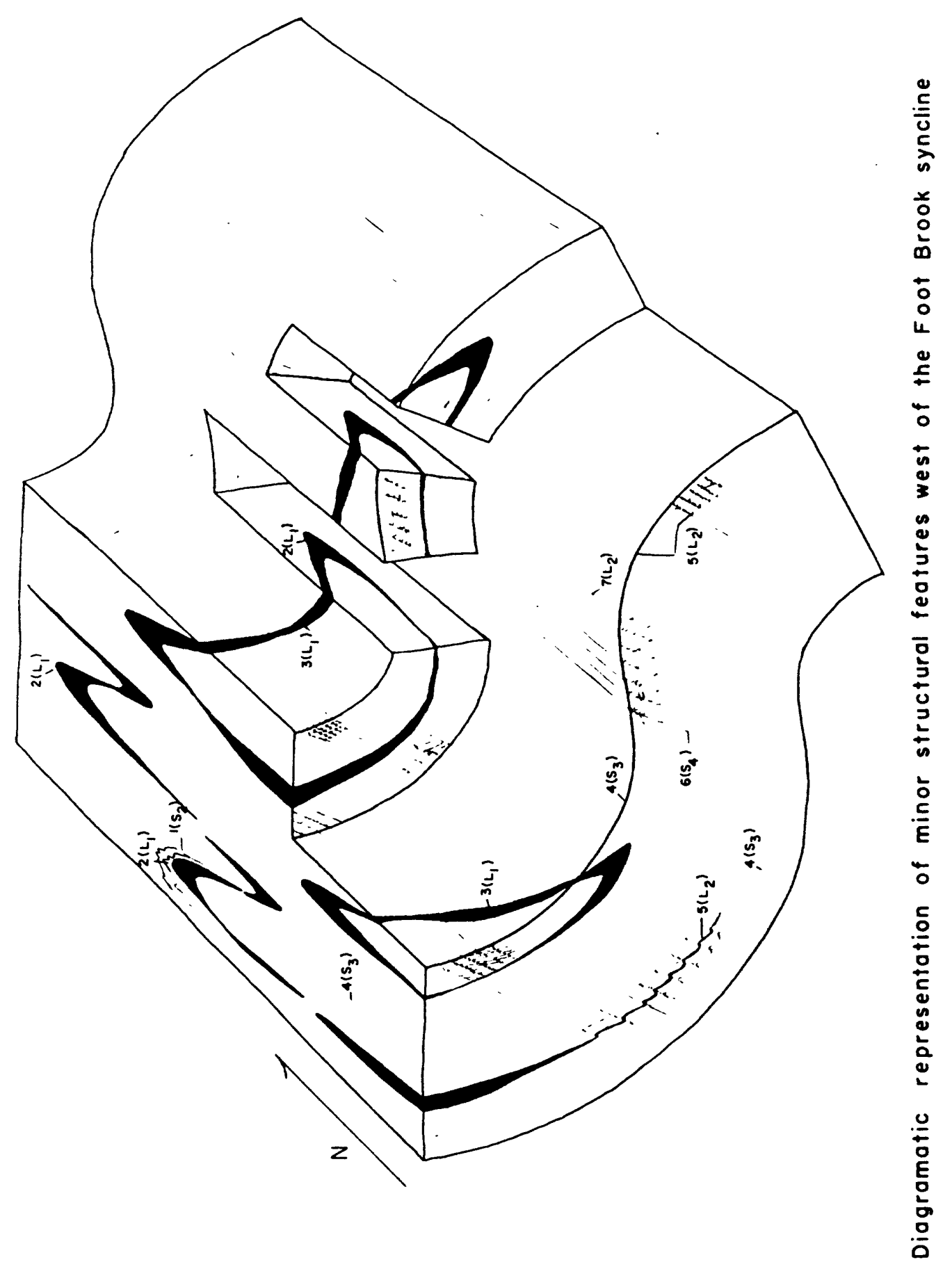


Figure 1. Interbedded micaceou quartatte and schist in caris Hump group. The schistosity $\left(s_{2}\right)$ is parallel to the beddin $\left(\varepsilon_{1}\right)$

Pigure 2. cuertz zogregaticos in quartz-serleite-chlorite-

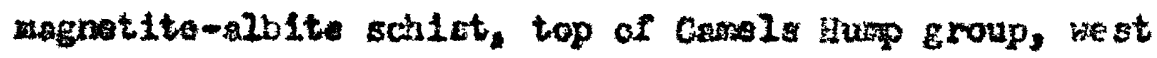
stie of Terrill Hill (Morristown).

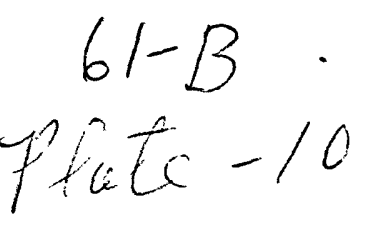




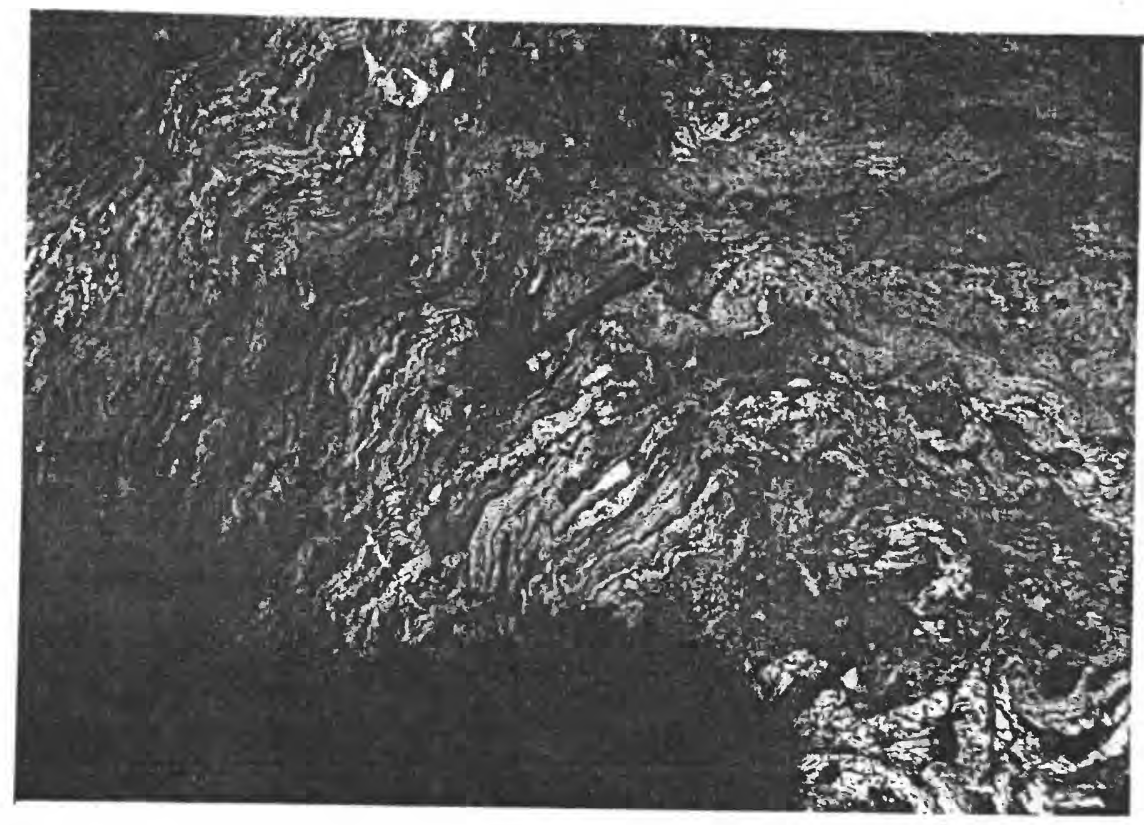

Peare 1

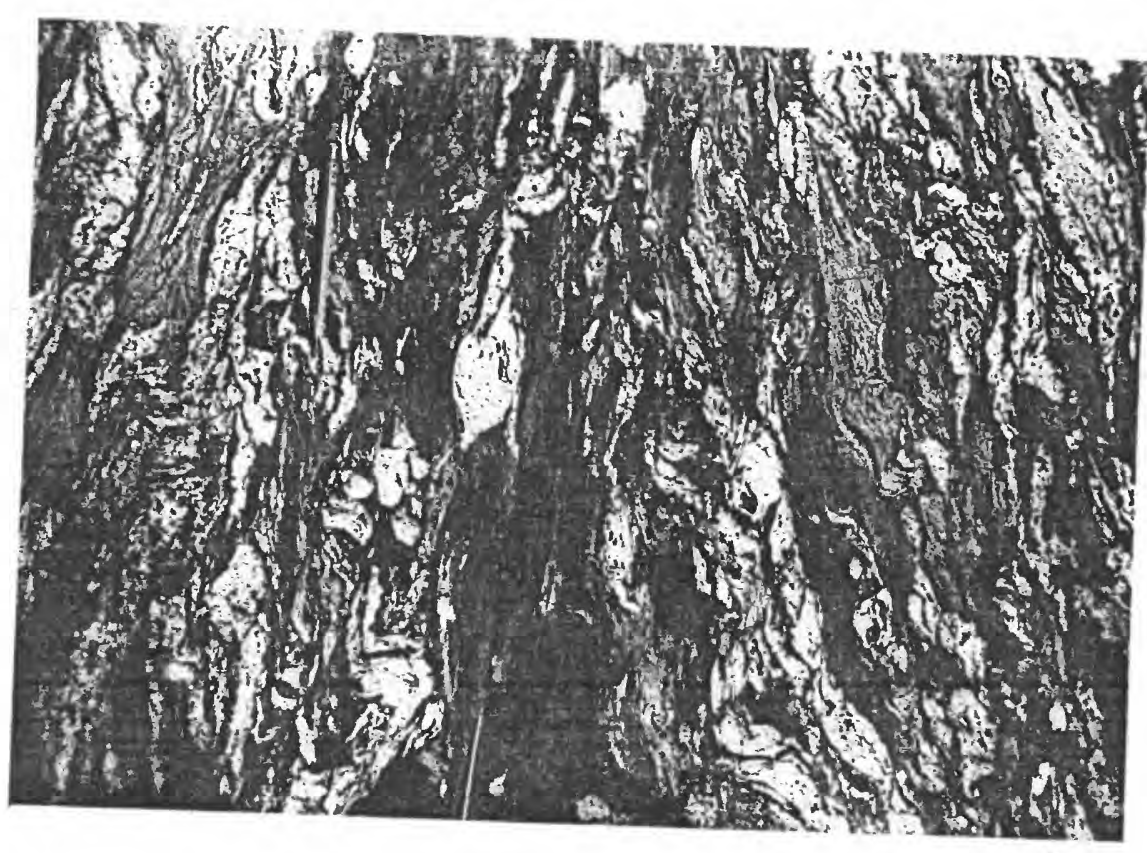

25pura

$2=10$ 
Figure 1. Interbedded caceous quartzite and aphitic echist in

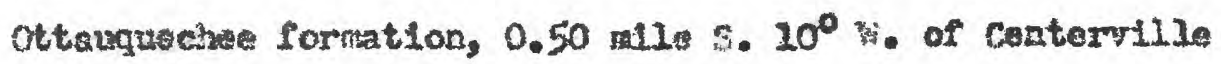

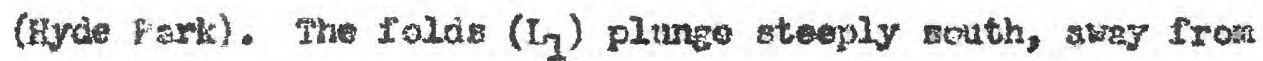
the canerg. The quartiste bed near the hamer has been notated and its ends stretched or fibograd off.

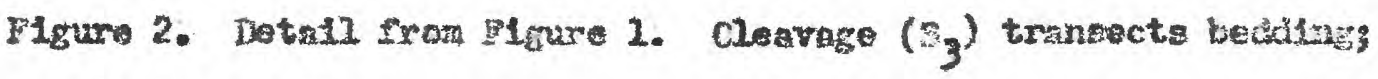
It Is parallel to schistosty $\left(\sigma_{3}\right)$ in adjacont sohist.

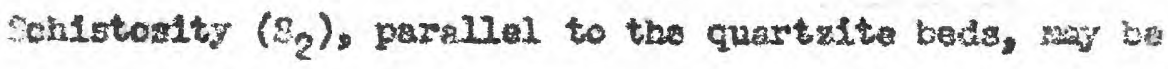
sean at top and botton of tho rhotograph.

$$
\begin{gathered}
61-C . \\
\text { Plate-II }
\end{gathered}
$$




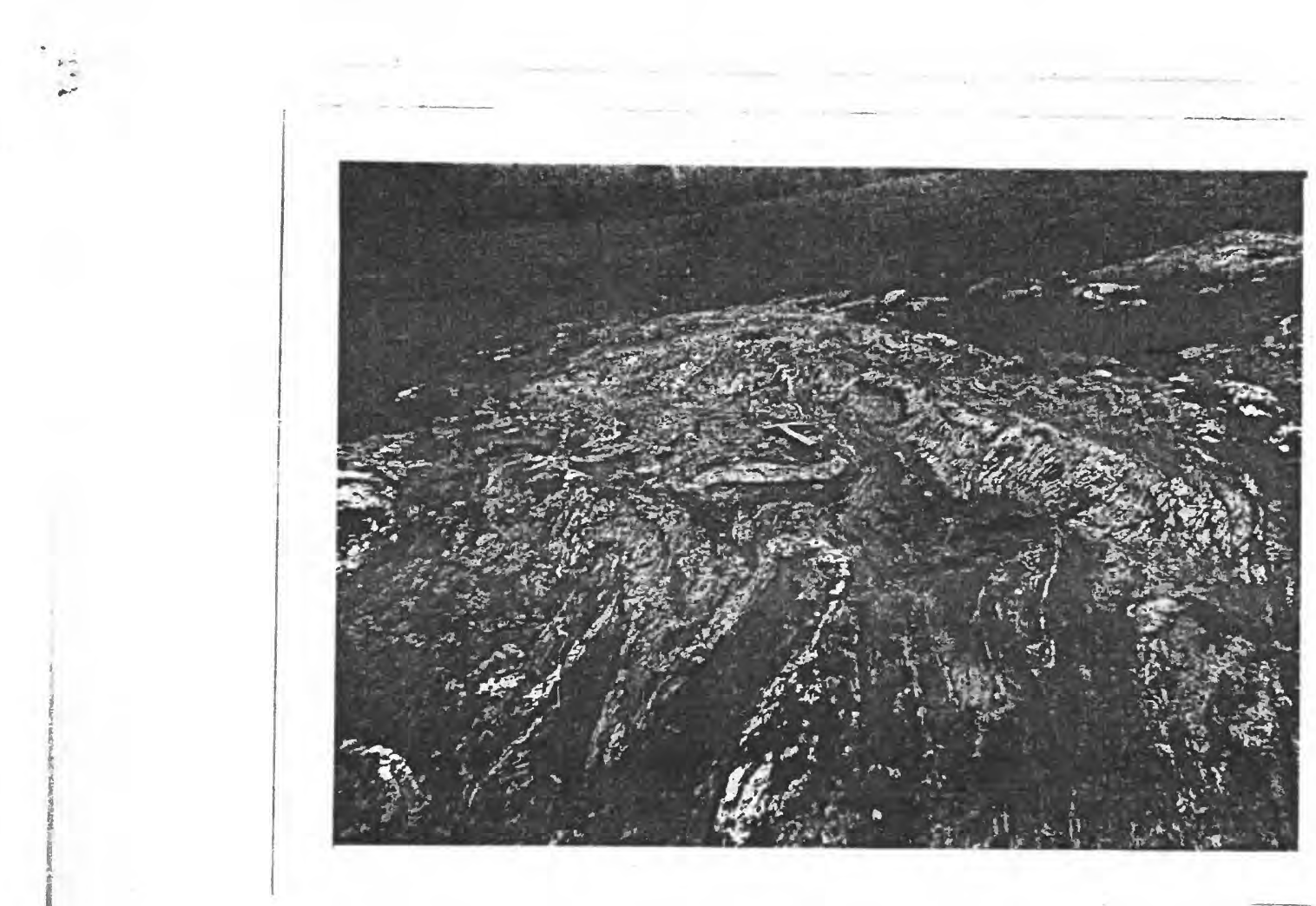

F⿻上丨 1

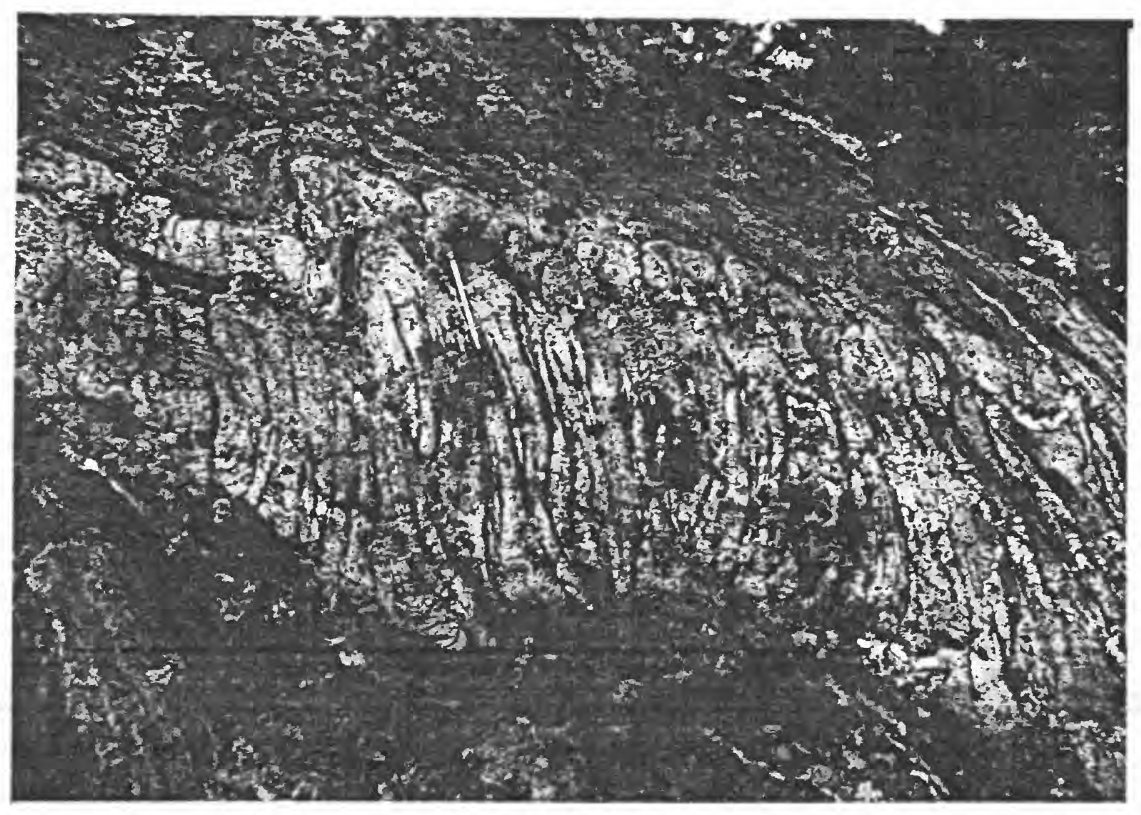

$78+20$ 


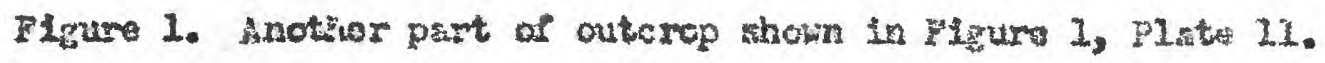

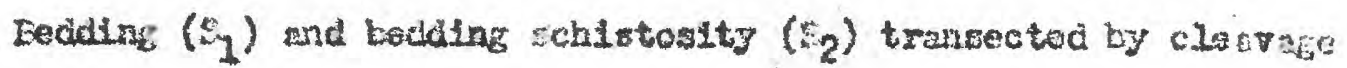
$\left(s_{3}\right)$. Polde $\left(L_{1}\right)$ plunge steoply south wway frow the carasm.

Figure 2. Dotali of Pigure I.

$$
\begin{aligned}
& 61-D . \\
& \text { Pate } 2 .
\end{aligned}
$$




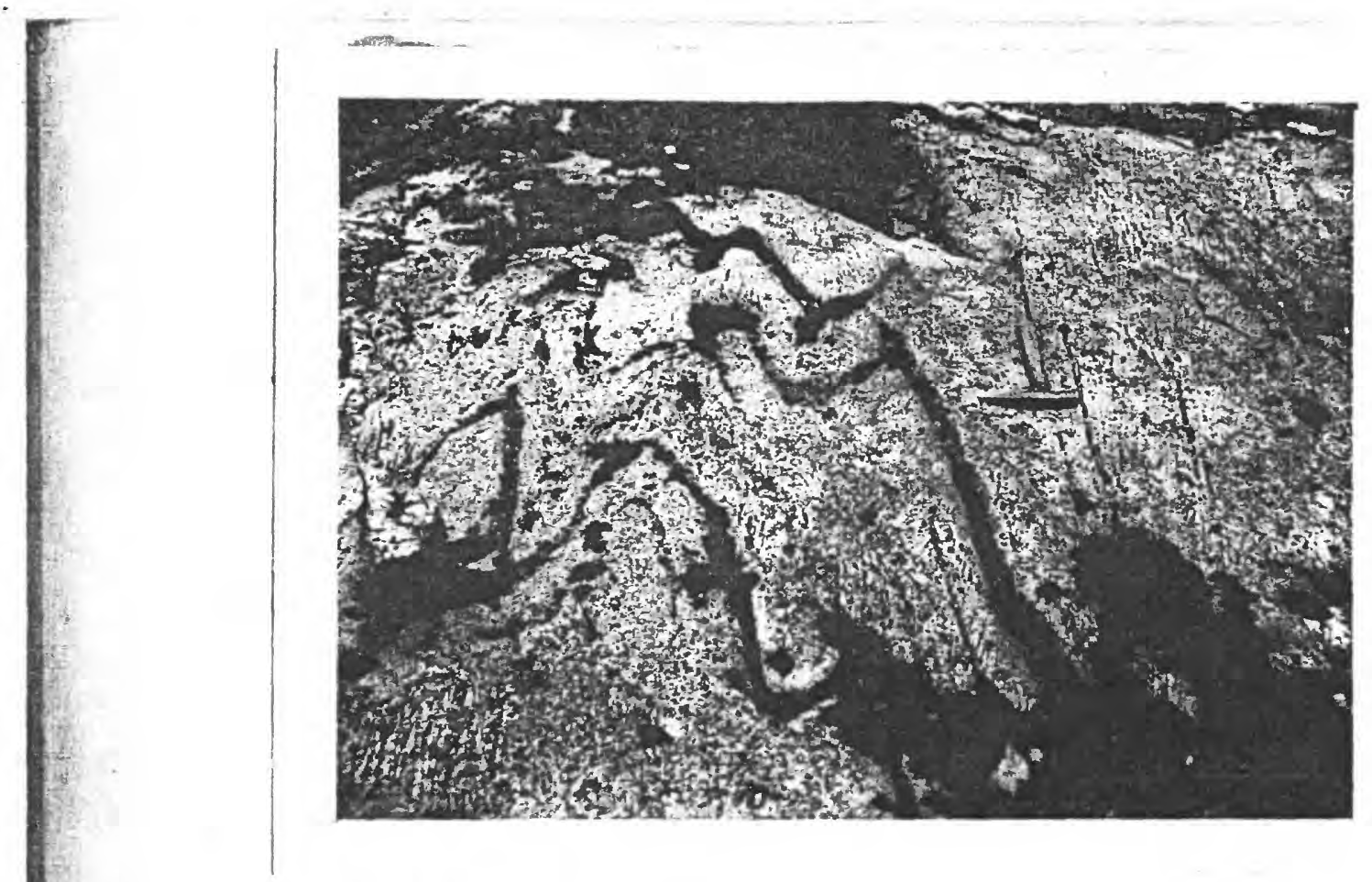

PLow

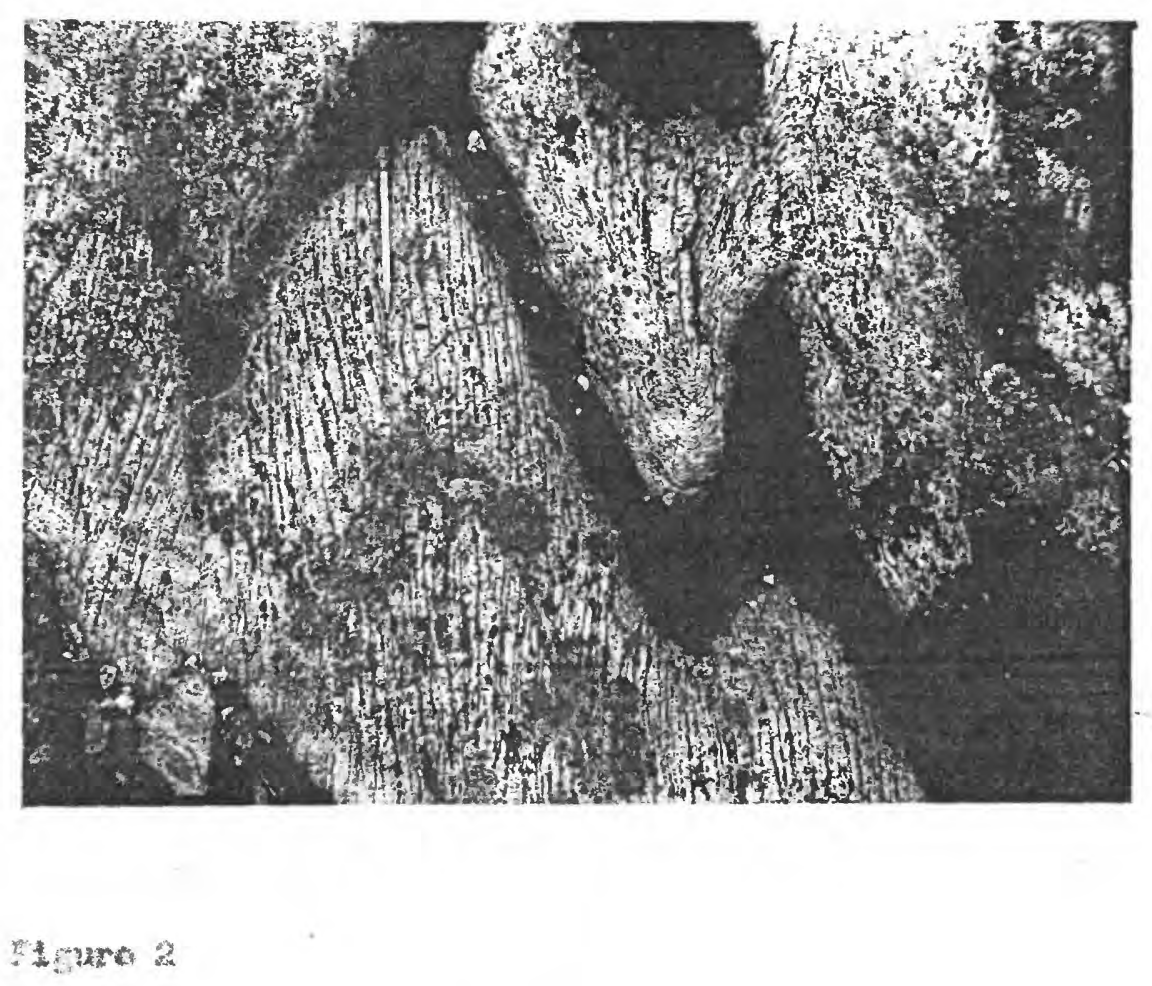

stata 12 
Figuro 1. Close-gpaced cleavere ( 3 ) parallel to sulil planes of I folds. Eedding sohletosity ('2) If nesily obliteratea. stows cormation, 1.20 alles $\% 65^{\circ}$ a of the alte of savie Hel ghtorkood school (Johnson).

P1gurv $2 . s_{3}$ plenar ctructures trenecting bedding follation $\left(s_{1}\right.$ and $\left.s_{2}\right)$. In verlous perte of the phatograch the $c_{3}$ planar etrueture coula be called a glin cleswage, a fracture

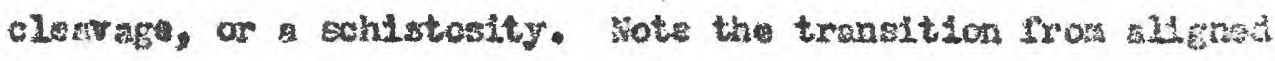
crinklea linto o well-daveloped planar atruktare.

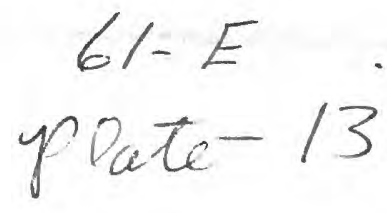




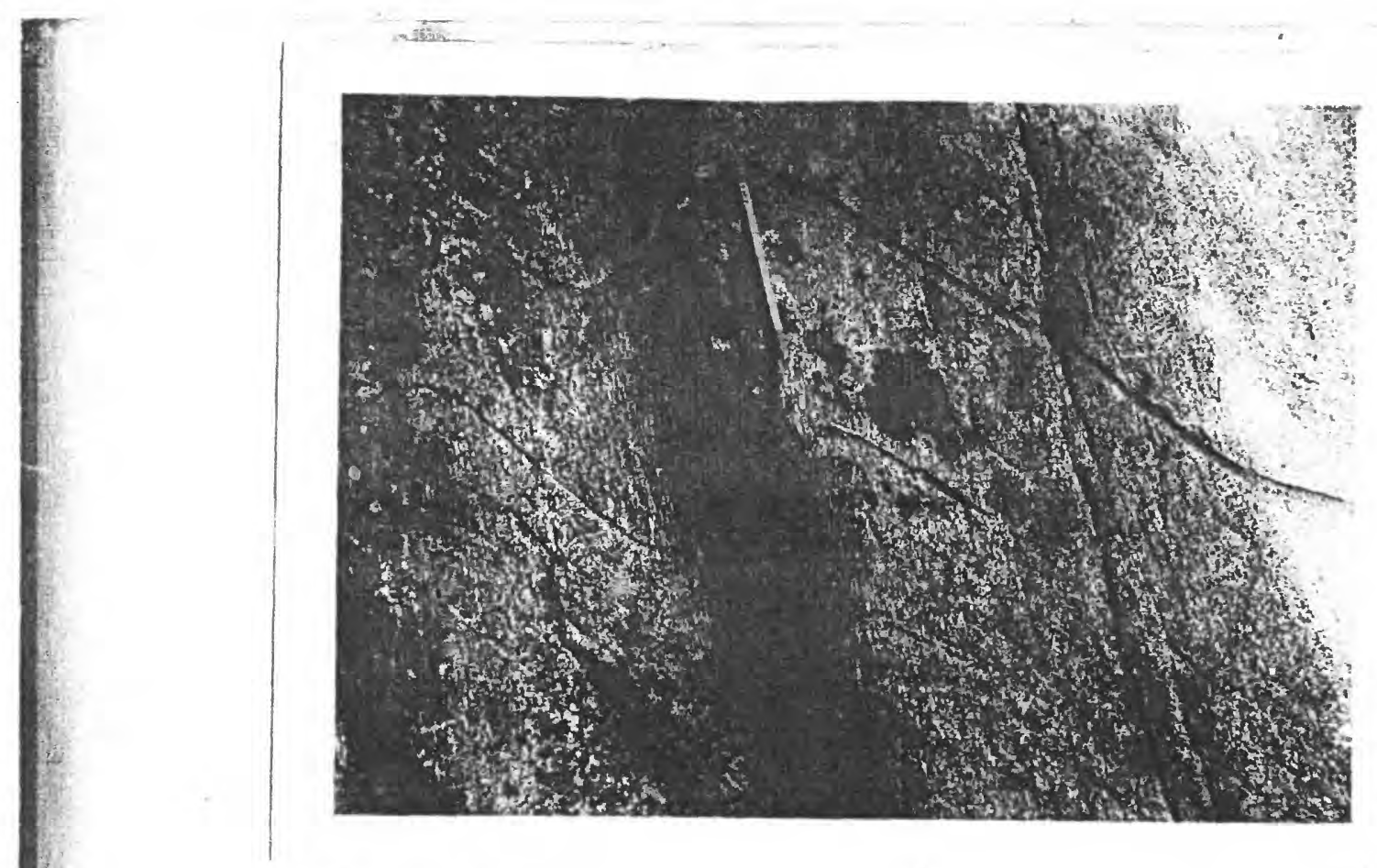

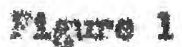

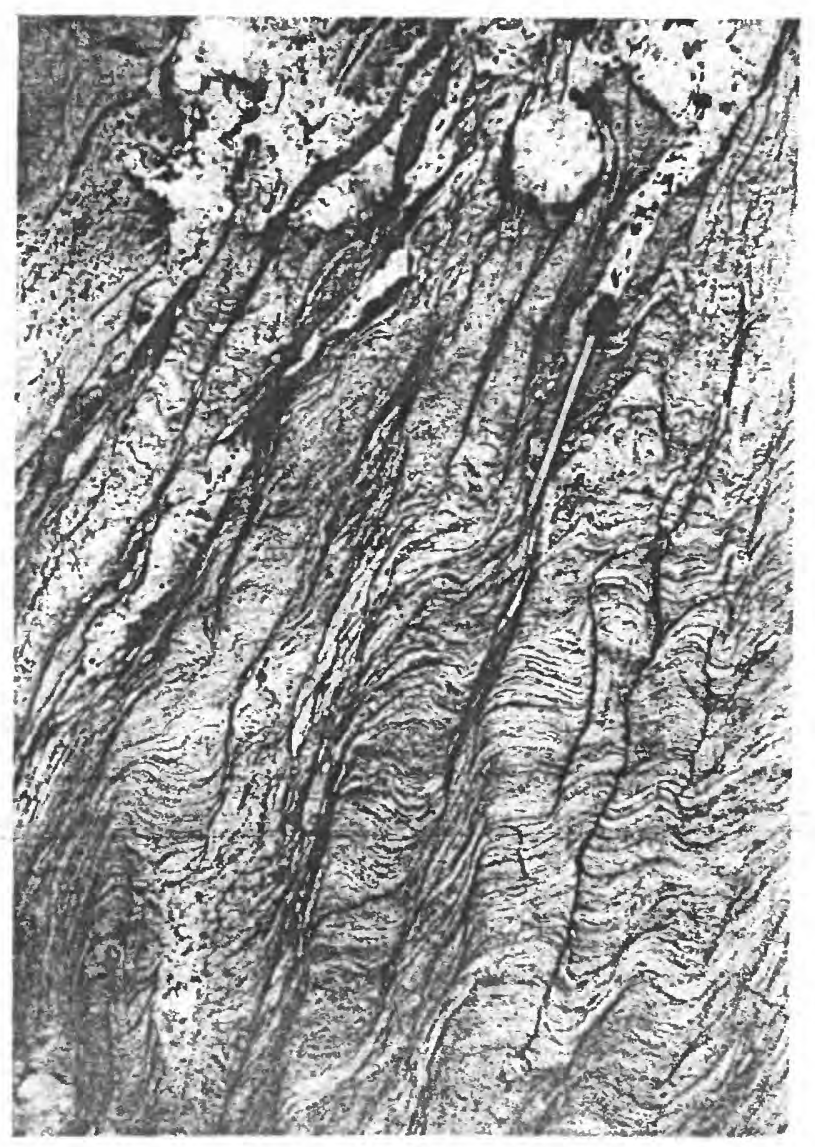

5.120

Fute 13 
P1guro 1. Schlotosity $\left({ }^{\prime}\right)$ on left alde of photograph in aicacacus beds 15 parallol to clarvage (s3) trangecting the boddiug fall:- tion ( $E_{2}$ and $F_{2}$ ) of the ndenecous quertrite bod in the canter of the photograph. The gurtisite bed is eut oft at sach enc

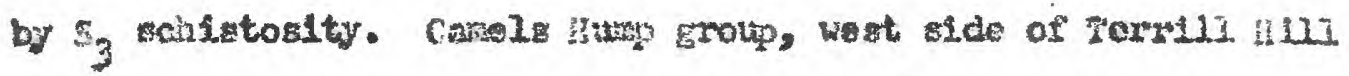
(homistown).

Figure 2. Fypleal derelopant of $s_{3}$ plmas structures in quartzose

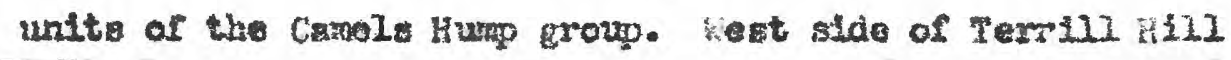
(Horrigtous:).

$$
\begin{gathered}
\text { 61-F } \\
\text { Plate-14 }
\end{gathered}
$$




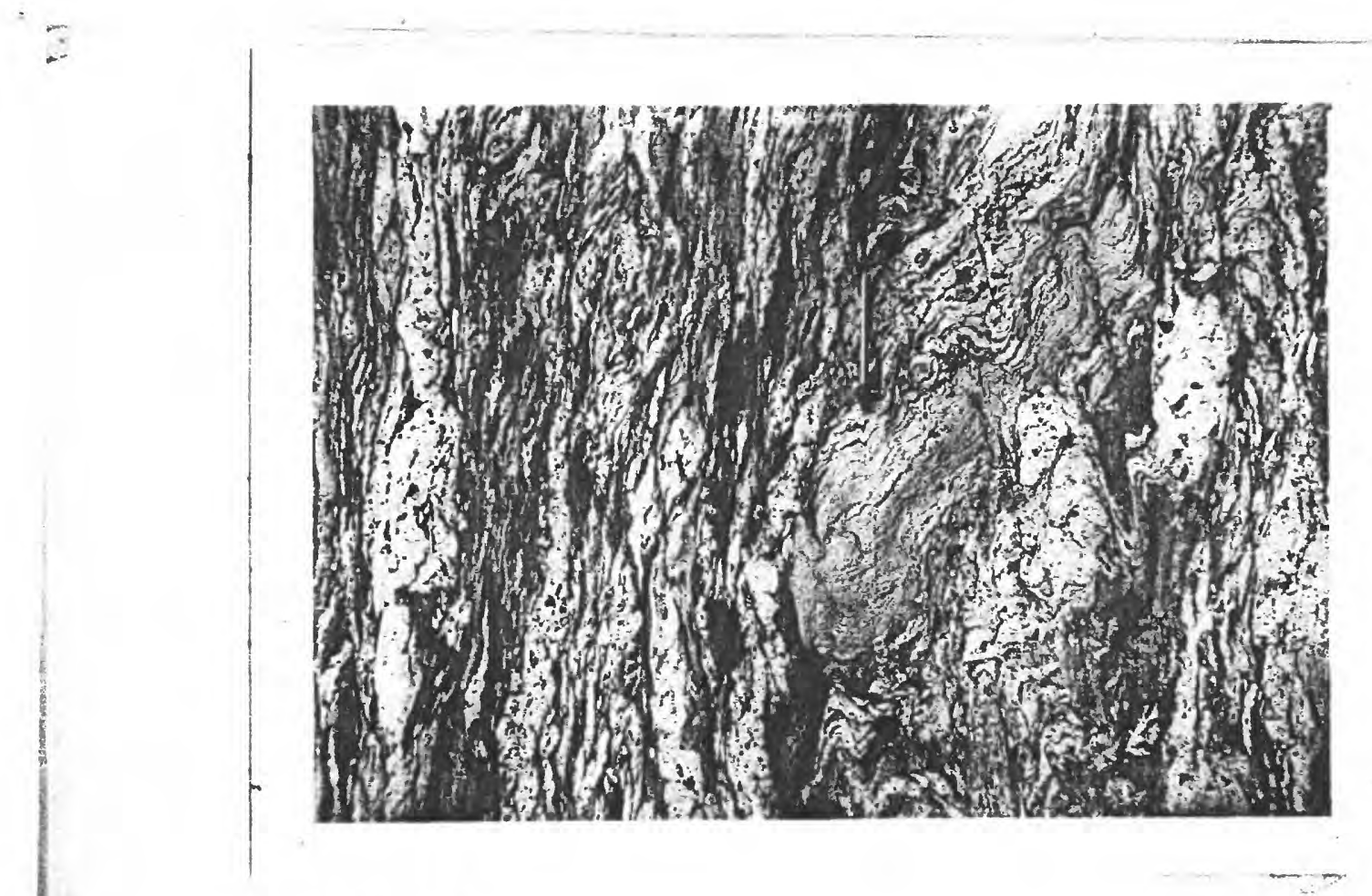

\section{S1gure 1}

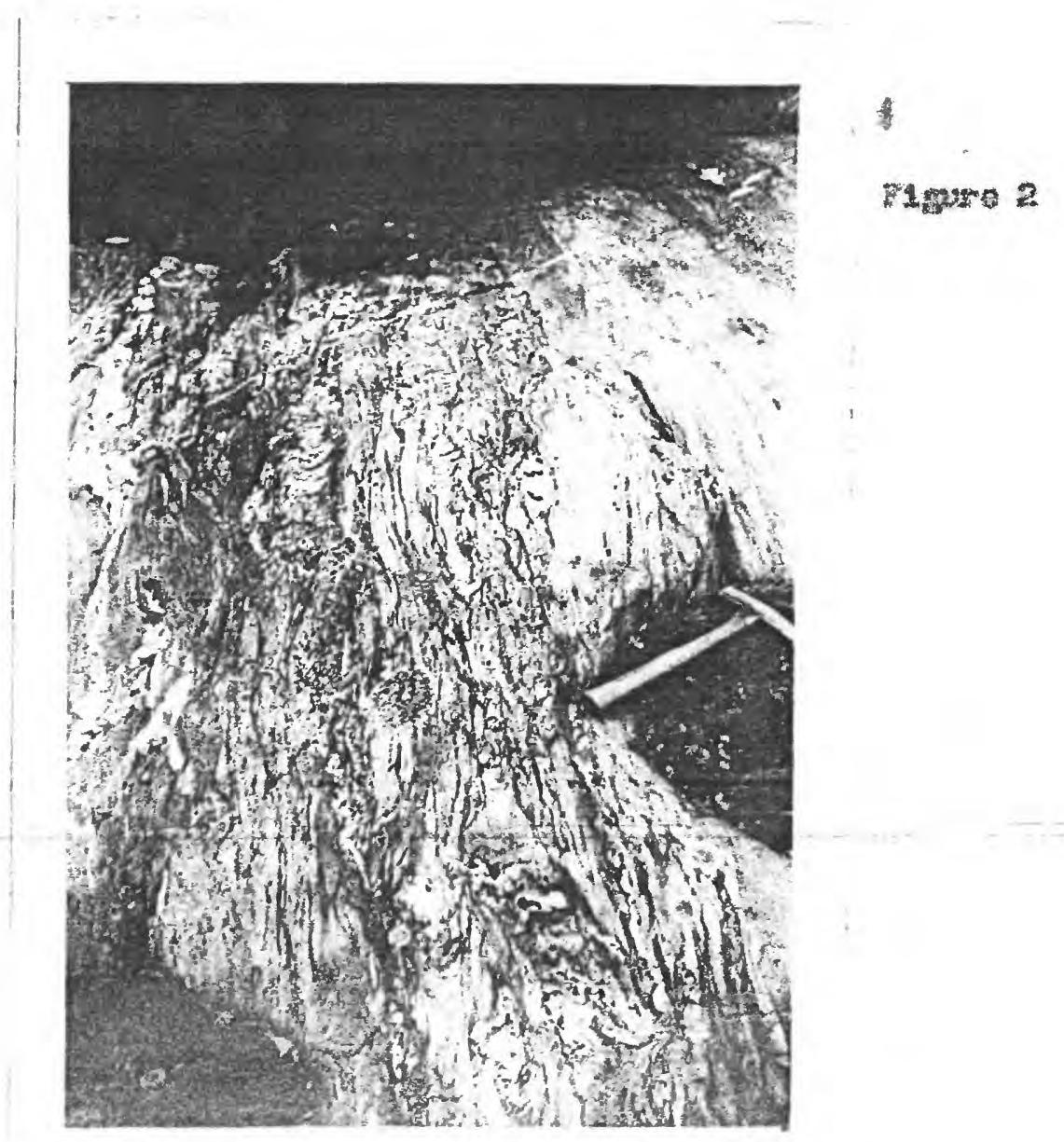


Fifure 1. The If aht-colored currta farka the intersuction $\left(L_{1}\right)$

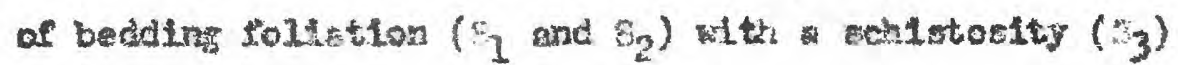
Which transects the bodelne follation and wheh forms the surface of the outcrop. The pencll is perallel to fline crinklos and Larger folds $\left(L_{2}\right)$ which deform the other etructures. Colo hum grosg, 0.72 mis K. $80^{\circ}$ \%. of the olte of Riverstid Sehool (Johneon).

Fleure 2. A fold $\left(L_{2}\right)$ in guartalto extende through tho spectana with its fold oxis paraliel to tho mochanical poncil and the clgarette. The crest of the fold is traneacted by \& cleavage $\left(E_{3}\right)$ paralled to the schistosity $\left(f_{3}\right)$ wit ch forms the upper surfece of the poctwon. The cleavege and schiatosity ( 3 ) and the fold $\left(\mathrm{L}_{2}\right)$ are folded about an axds parallol to tho

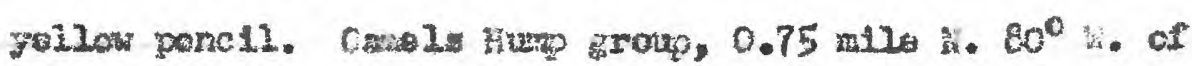
Riverside sihool sito (Johnson).

$$
\begin{gathered}
b 1-9 . \\
\text { plato- } 15
\end{gathered}
$$




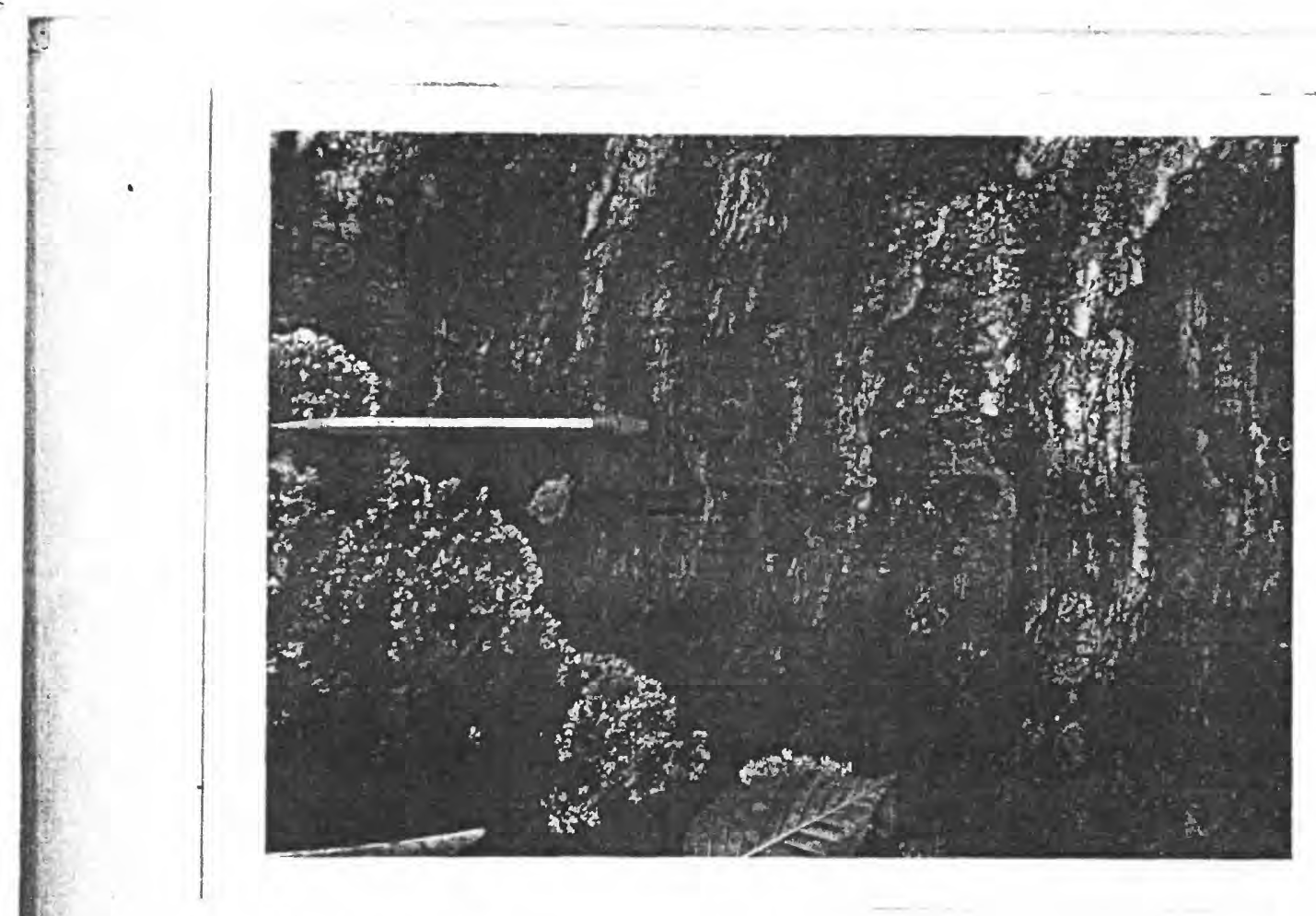

\section{FI fure 1}

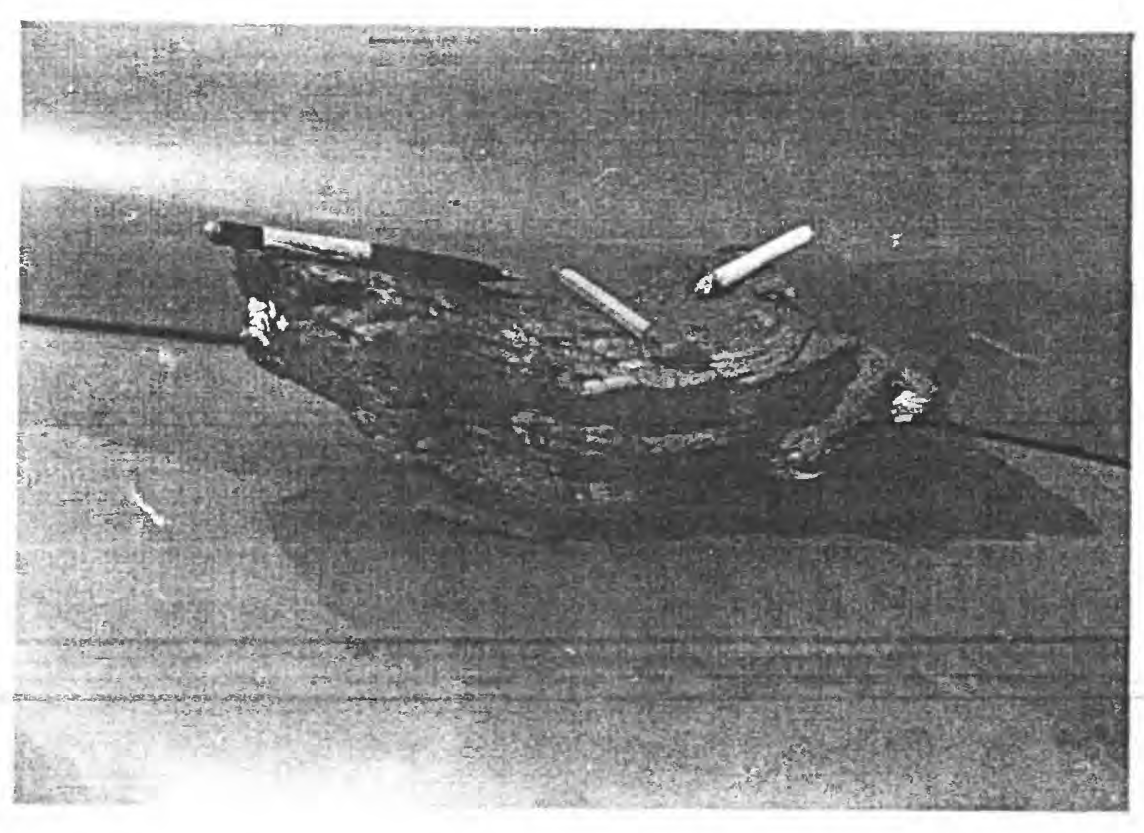

Mgare 
F1gure 1. Dark pancll parallel to axes of $I_{1}$ folde in masive gray qunrtest plungire southosst. What parcil parallel to axee of

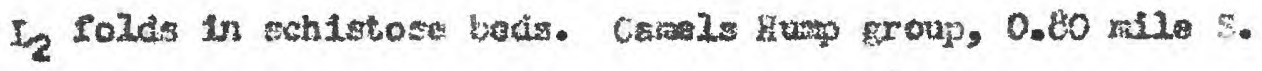
$45^{\circ} \mathrm{E}$. of the ste of Hillste cheol (Johneon).

Fisure 2. Cleavage $\left(s_{4}\right)$, outlined by wate chalk, trangecting ing

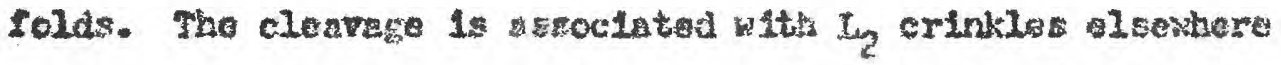

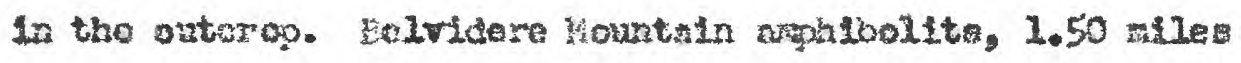
3. $50^{\circ}$ n. of the the of sescon shool (reter).

$$
\begin{gathered}
61-H \\
\text { Pat }-16
\end{gathered}
$$




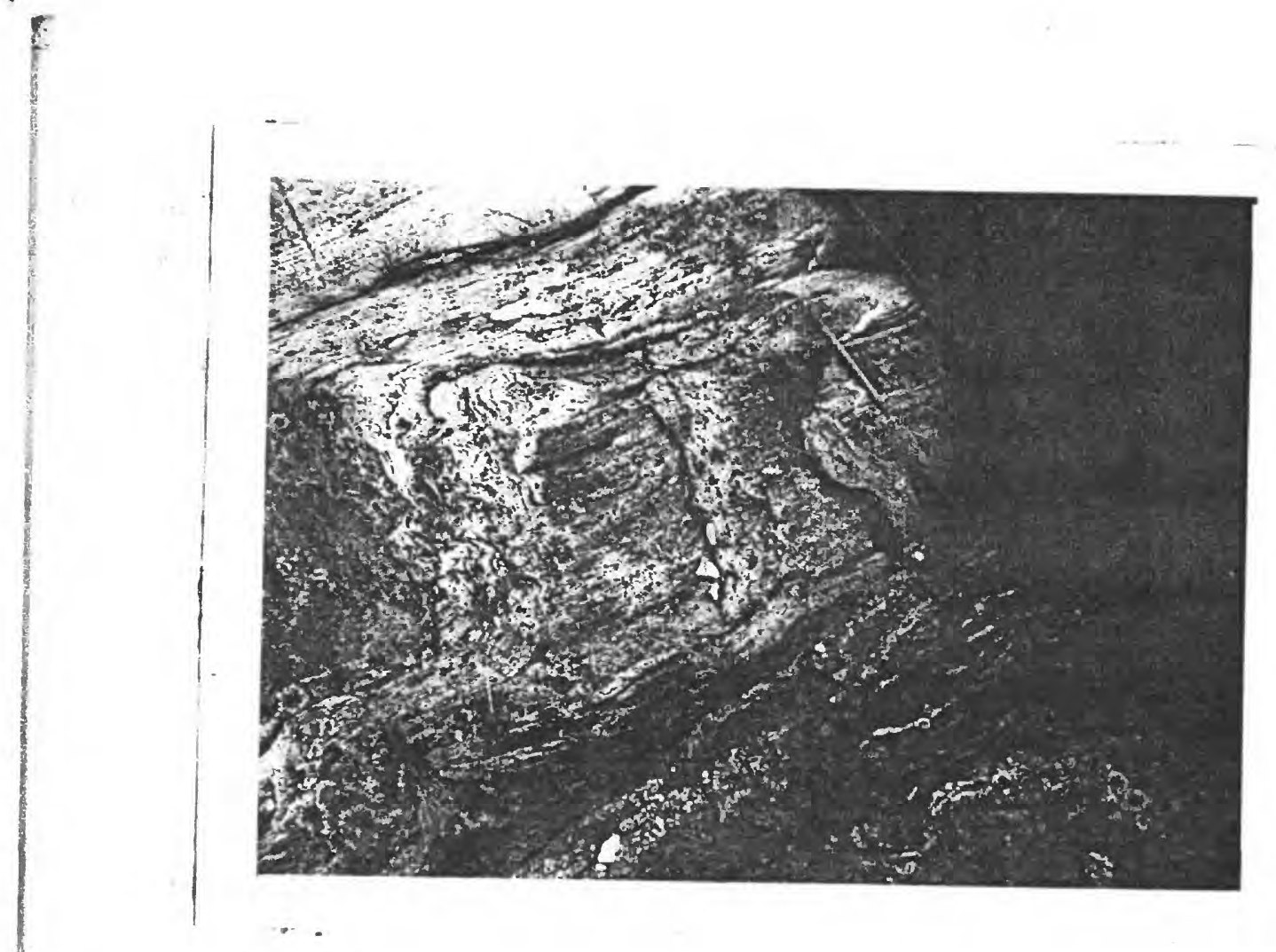

Fgure 1

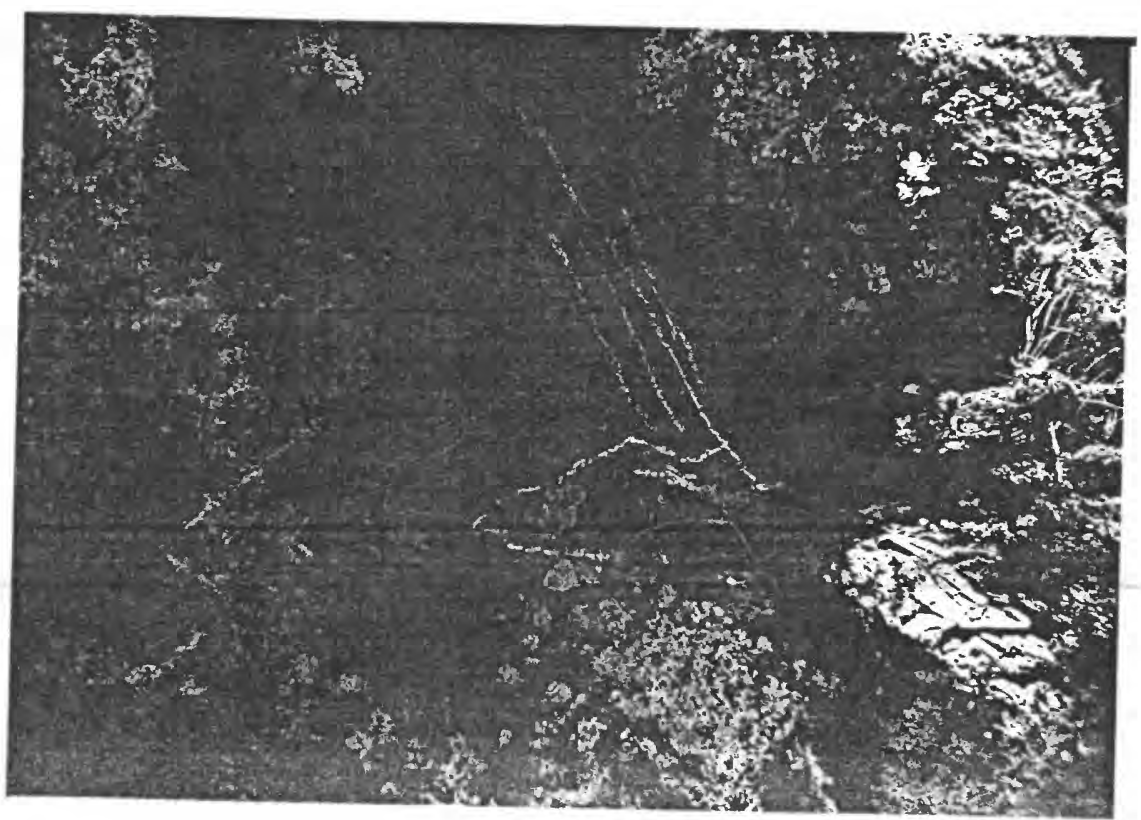

Ingro 
conmonly quartizte elearee readily due to the segregation of the small arount of miceceous wineralo into thin parallal oursces perellel to the bedalns (Plate 13, Pleure 2). "he scinatosily $\left(3_{2}\right)$ is locally noarly completaly obscured where the $3_{3}$ or $5_{4}$ planar fatures are wall developed (Plate 13, 11guro is Hate 14, Pigure 1).

LI Inear roatures.

The $3_{1}$ and $3_{2}$ follations are folded ahout axes noarly at right angles to the axis of the Groen Kountain ant lallnorfus. These in fold axes and Innar festures parallol to the plung east where the bedding folfation $\left(s_{1}\right.$ and $\left.s_{2}\right)$ dips gently oast (Plate 16, flgure 2 ) and plunge nearly rert1cally-generally steoply south-where the dip of the bedding follation 1s steop (Plat 11, ILure 1). There it no consigtent worent sense. In the central part of the area both dextral and alnistral folds, whose axes plunge stooply both north and south, way be observed in a atugle outerop.

These rolde $\left(L_{1}\right)$, which are beat hiom by quartafte beda in the schist, are rory tight with lang limbe oubperaliel to the follation in the aurrounding schlot. Thick asestre quartait beds form more open folds, whose short libbe and, leas comonly, erests may bo slloed up by closely spaced, thin atcaceous layers along whith so me displacewont has

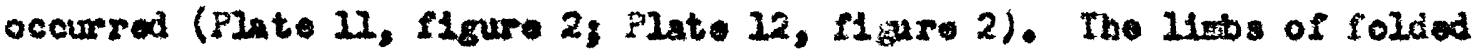
quartaf to bede and quarts lent1eles In the soni at are componly broken-ofther atretched or sheared off-ao that the crests of the folds are preserved as rods whose cross section is "U" or "g" shaped (RLare 2 ). 
these rod are eapectally abundant $3 \mathrm{~m}$ well axposod on the vest side of

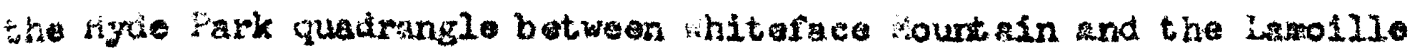
"ivar. Mthough the $L_{1}$ folds are numerous, the trand of the long limbs of these folds correspond wore closaly to the trend of the formation boundarles than does the overall trend of the clidetonty and eompositional layaring.

Erominent linestions prallol to the $h_{2}$ fold axes are farmod by the Intarsection of the schistosity $\left(\mathrm{S}_{3}\right)$ with the quartzose beds and lanticles $\left(s_{2}\right)$, streaks on the follation surface $\left(s_{2}\right)$, and aligrwont of gineral crains. furta lanticles, wich ar thought to have formed by metamorphle differontiation, are also comonly elongate parallel to the $L_{2}$ fold axes.

\section{S3 planar contures.}

The $s_{3}$ planar feature can be Identifled coly where it transeote podains follation $\left(s_{1}\right.$ and $s_{2}$ ) in $L_{1}$ folds (Plates $11,22,13$, and 14 ). Elambere it parallels the bedding follation and cannot be distinguished Fram 1t. Gonerally it is a enletesity or a elip oleavage, locally a fracture cleavage. In the erest of thick quartalte bude the $s_{3}$ plenar pructure constate of parallel frecture elearage aurfaces containing pleacecus minorals orlented parallel to the surface (Plate 12, Iigure 2), ut in adjecent ulicaceous beds it consiats of a schiotosity. The linbs I' quartsose beds and laminae are shesred of or strotchod out along Ianes which parallel the foliation surfaces these planes comony conain schistose layore or thin iajers of platy minerals oriented parallel 
to the planoe ('late 13, flare 2; Flate $4_{4}$ ). All of these somewat difivront featur are belfered to bo rolats, the differaces belne due to aifferences in the raschanical propertios of the rocks ancin in the asount of shear which had to be accorabodated.

$\mathrm{I}_{2}$ Inear foatures.

All of the earlier ainor structures $\left(s_{1}, s_{2}, s_{3}, L_{1}\right)$ are folded about north-tronding fold and crinkle azes $\left(l_{2}\right)$ which are subparallel to the axis of the Oreen Vountain antlolinorim (Plates 15 and 16 , and Fifure 2). These folds correspond to the larger rolds of the area. In goneral, the movoment sonse is "esst side up", corrosponding to the anet limb of the Green kountaln antielinoriua, but this is revereed on the west limbs of subsidingy anticlines. In the western and eastern part of the Hyde Park quadrangle these winor folds and the subsidlary larger folds are rather open flexcuros, whereas in the central part of the aras both the winor folds and the larger folds are belleved to be rathor tight.

Host of the minor drag folds in the cantral part of the area are inforred from tholr spatial relations to bo earliez folds $\left(I_{1}\right)$. The later set of folds $\left(L_{2}\right)$ in the central and eastern parts of the quadranglo is repreaented by fine crinkles with an asoe lated slfp clervge, and by gontly west-dipoing follation that occuss 100 ally on the west IImbe of Larger anticlines.

The intersection of 8 lip clearage $\left(s_{4}\right)$ with the earlier follations ( $s_{1}$ and $s_{2}$, excopt in $L_{1}$ fold crests, and $s_{3}$ ) forms a prominent Iineation 
psitalial to the $\mathrm{L}_{2}$ rold axes.

"Ithouh only two distinct sats of rolas are ceserbed here, it ia possiblo that tils is too simplo a plcture. Suparlaposition of tho two sets is clearly ohown anly in the wootern pert of the Hyde Park quedran310. It is poosible, partioulariy in the catral part of the guadrangie whe minor structural relations are not as clear, that the earlior set of folds $\left(L_{1}\right)$ was prooeded by folds having the same orlentation as the later set of folds $\left(L_{2}\right)$, even though such structures have not been recognizad.

S. planar fentures.

SIlp closrage is assoclated with sall crinkles $\left(L_{2}\right)$ whit ch are oubparalloI to the axis of the Groen Nountin anticilnorium (Flgure 2). It Is best dereloped in the weotern and eastern parts of the Hyde Fark quedrangle. It generally tronds marly north-south and dips ateoply weot, parallal to the axial planes of the larger $L_{2}$ folds. The opacing of the surfaces ranges from a fraction of a millinter to sereral centineters. The Interection of the ellp elearage $\left(s_{4}\right)$ with the $g_{3}$ follation planes consiatently perallels the sxes of the associated folds and crinkles and the spatial relations of the two planar features indlates the relative novenent on the $S_{3}$ follation plane (Figure 2 ).

In the Stowe formation slaty cleavage and ochistosity are tranaltonal into alip clesrage. In some cases the crinkle, that is coxeonly assocluted with slip cleavage, lo absent or has been completaly rearyetel 1ized; in others it is preeent. the slaty clearage and the sehietosity 
parallel the axtal planes of folde, mere these way be obsurved. This

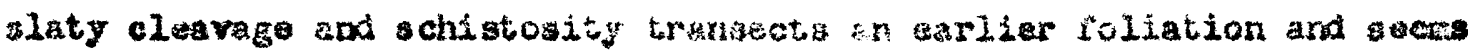

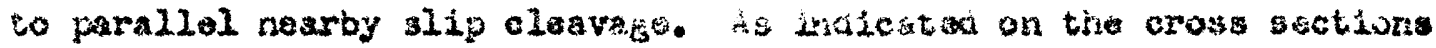
these planar features secu to be aubparallel to the exial planes of the larger folds. The schictosity $\left(b_{3}\right)$ in the central part of the area bears similar spatial relation to the inferred anjor folds, but its relations with $L_{2}$ folds and the fret that it is locally transectod by slip clearage $\left(s_{4}\right)$, makes it pos ablo to dif ferentlate $s_{3}$ and $s_{4}$ plsnar foaturea in thi s central arou.

Fracture eleavage was nct ed $200 \mathrm{ally}$ in competeat beds, but it is not comon in the Hyde Park quadrangle. The general apatial relations Initoate that it 1 probably related to the other $\$_{4}$ planar structurea, but no conelisive ovidence has boen found.

$i_{3}(?)$ Innear features and $s_{5}(7)$ planar foatures.

In the Norotown formation and 100 ally within the upper part of the Stowe formation, flgoold 1 lexures $\left(L_{3}\right)$ and eleavage band: $\left(S_{5}\right)$, that rosemblo anall faults, offect the schistoalty. Camonly the schlatosity pasees unbroken through the eleavage bards, but in some an actual fracture $1 \mathrm{~s}$ present. These structures may be seen 0.60 mila $5.80^{\circ} \mathrm{s}$. of

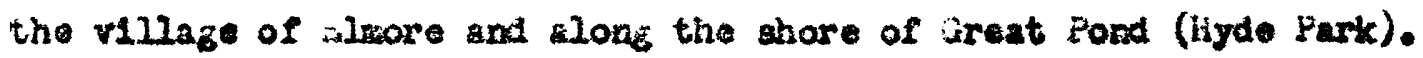
The pattern is generally dextral, and the cleavage band comonly strikes morthweot ani dipo vertically. These sesen to have forned later than the two sets of folds described previously, but no conclualve evidence has been found. The sani general wovent senso-rocks to the east movins 
south relative to those to the weat-1s widespread in the kontpelior fuadrangle (Cady, 1956).

\section{jolnts.}

ho myteatic study of tho joints was undertaken as they are younger than the major defcrmation and the metamorphism, and thue sound to offer Itt te help in understanding the deformation. Frominent joint systens wore noted along the creat of the Grean kountain anticlinorlue and upon the crest of Eilmore Yountain (1lowe). The genernl treads of these were northeast and northwest, dipping nearly vertically.

\section{Ioteted porphroblute.}

Albite porphyroblants commonis anow an S-ahaped allgnaent of Inclusone In thin sections, which is assured to indicate a rotation coincldent with grouth (Heage, 1930, p. 32). The arrangenent of these 1 ineo Indis ates the rotational sense. The pattern can be seen only in thin sectlons oriented about mrmal to the axis of rotation, which is paral202 to the fald axes. The Insluaten of clinosolatbe-pidote, graphtte. rutile, serle1te, chlorite, 1lmentte, and quarts are fine grained ard abow pesoforred planar orlentation. It 10 presumed that this preforred orlentation was orlginally part of the schictosity, and that the graina were included as the porphyroblast grew. The radius of curvature reIects the reloeity of shear relatire to the rate of growth of the porphyroblast. Inek of currature indicates growth without rotation. Inclusions aligned in atralght Iine at an angle to the schistosity indicate rotation after grouth had ceased. 
The Incluslons indieate that a crinkled schistosity was present be-

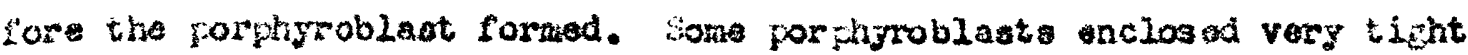
cririklas with an assoclated alfp cleavage. In ame spocimons the crinklea ore tight that they mast bave formed when the rock was finor gralnad than at present. Couruonly the porphyroblasts were rotated after completion of growth, but Indioation of growth durlng rotation and of lack of rotation have also been observed. A alnglo thin section contains alb tte porphyroblaste with the following four different paragenetic secuances: 1) growth of porphyroblast, followed by rotation with growth continuting during rotation and with wo further rotation after cessation of erowth; 2) growth of porghyroblast, followed by rotation whout further growth, followed by grouth without further rotation; 3) growth of porphyroblast followed by rotation accompanied by grouth s low anough to exclude inclustons klog folloued by rotation without further growth. Such combinations suggost that no simple pleture of the morement involved can bo formed, alhough no grtenatic investigstion of the gor munt cense was undertaken.

\section{sabre.}

Cortaln features of the fabric of the se rocks oupport the lace of post-tectonie recrystallisation arter gliding, fracture, and grain roation bas ceased. Undeformed tabular porghyroblaste of chlorttold are riented at a large angle to the achlotos1ty, and garnet and kranito porhyroblast contain very Pow fracturos. Inclualons in garnot indicate hat no rotation occurred, and kyanite blados do not heve a preferred 


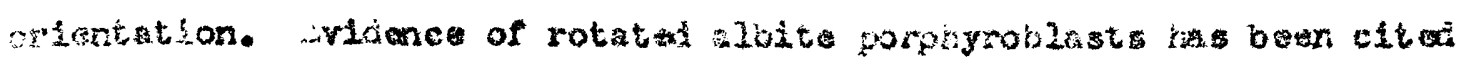
seriously.

A mole pattorn charactarizes the fabric of quartzites and of Guartz-rich layers in seh1st. It consists of Intersections of grain boundary at about 120 degreas between three grain. Hide variation in grain 6200 , varlable oxtinction, and ovidence of cataclastic atructure are rare in quartz, and tulnuing 2 aminae aro rare in cartonate and albits grains. It is belimed that these fatures were destroyed by anrealing or recrystallization wh ch continued beyond deforwation. Letrograde bextures are abundent in the garnet and kyantte sones in the Stowe formation. Camnot is altered to pieudomorphie aggregates of fine-gralned chlorite and gatite with rolles of garnot; lyaulte is altered to paeucionorphle aggregates of flne-grained mucovite and coarse plates of muscorite.

relation of ainor stractural festures to major struetural features All the winor atructurial fatures are compatiblo in guaral war Lth the anjor etrueturea in the Hyde Fark quadrangle. However, wile ho second atage folde $\left(L_{2}\right)$ and allp elenrage $\left(s_{4}\right)$ alded the oynthesis ff the major structures, the earlier folds $\left(I_{1}\right)$ did not prove useful in his synthosis. In wach of the area the seoond stage folda $\left(L_{2}\right)$ are unpraton, and the observed folds and follations soen to bear little direct zlation to the ajor structures. This difficulty is llintrated diafammatically on tho crose noctions (Plate 1 ).

The essterly dip of the bedding soht otoulty inerenses eastarly from ho axis of the Grean irountain anticlinoriua to the exposures of the 
Wttauquachee sornation in the Foot Brook sncline. In this area brosd rolls, crinkles, and slip clearage, with natriy horizontal Ilnoer elements closely parallel to the axis of the freen hountain anticlinoriut, indicate that younzer beds are to the oast-drag senee is cast olde up relative to west side. the early stage of deformation is represented by ilarta rods and sparse tightly folo quartalte bed with axes sub;orporiflcular to the axls of the Groen Vountain anticlinoridn. The ralationsilip of varlous minor structures near the axis of the Groen fountain anticlinorium aro shown in Figure 2.

The prominont minor structural fenture in the 3tore formation axposed in the voot Brook syneline is alip clesrage and alaty cloarage (Flate 1, section $\left.A-A^{\prime}\right)$. The bedding schlstostty comonly trads northeest to east; the fold axea comonly plunge stesply outh. hoverer, the syneline, es intarpreted from the mat pattarn, wast be rather shallow with a nearly hor1zontal axis. The attitudes of quartalt beds and of the trmolitic amphibolite und indicates that the oast limb of the syncline 18 overturned to the west. Hinor structures in the Carels lump yroup wouth of the Iamollle Rivar fre little indication of the southrard axtonsion of the axis of the Foot Brook ayncline.

Similarly, the axd of the anticlinorlum between the Foot Brook symcline and the Ottauqueche formation in the eastern bomoclinel sequenes could not be located. Folded quartsite beds aro abundant in the Camals rump group in this central area, but socond atago minor features are uncomson. The long Ilebs of folds and trensverse schistosity combony trend northerly and dip ateeply osat. The bedding trend ranges widely. 
but the fold axos generally plunge steoply south. In the narrow guartzsariclte-chloritemignatite schist band at the top of the camels liump group the long 2 inbs of folde and the transveres schistostty are noro nearly parallel to the trand of the band than the bodding trend.

$A$ silown in section $A-A^{\prime}$ steep schistosity is the dominant winor structure in the Ottauqueche and 3tore formattons on the east side of the quadrangle. In sose parts of the stowe formation (Upper Dicgings) this epproactio a slaty cleaveg, which perallels a allp clesvage $\left(3_{4}\right)$ and assoclated gentiy plunging crinkles $\left(I_{2}\right)$. Southeast and esst of Garflald (hyde rark) major fold axes were located by the rolation of these etructures to the carlier schlatosity. In the Ottauqueches and in part of the stowe farmation the steep vahiotosity, a $s_{3}$ planar structure, 1s belleved to be earlice than the ellp clavage. Thronghout the Stowo formation the attitudes of the greanstones and anphibolited conformed to the ajor structures. Such sttitude wo particularly uearal in the vict nity of Elmore Mountaln (Blworo) wore the ochl at of the kganite rone 18 inteneely deformed (PIate 1 , section Bu31).

\section{orteln of ntinor structures}

Sereral explanat lons seen possible at first for the occurrance, one upon the other, of tyo ants of folds with the moverent sense at $2 \mathrm{arg}$ sngles to each other. The later sat of folds, parallel to the axis of the Groen Hountain anticlinoriwe, is al arly related to the folding of the Green hountain anticlinorium. One might try to explain the fold: subperpondlcular to the axis of the Green kiountain antlelinorian by 
ather the sotion of ajor horizontal shemring couplo younger than the rorth-south axis or by carlier folding about east-trending axas that ware later folded with the antelinoriua. The first axplanation would require a more consistant pattern of hese sense and a more consiatent orlentation of the fold axes than is shown in this area, and also that the strata were nearly vertical before rotation in the horlactal plane took place. It would not explain tho gently esst plunglng fold axas found near the crest of the enticlinoritu. The second explanation would require conprosolon it rifht angles to that rospansible far the Green kountain anticlinorlux. Yoroover, folding which could produce the numerous tight ainor folls of the earlior set seen in this quadrangle night bo cxpected to affect markedly the pattern of the mo, producline wide departurae from the rather inple northerly trend of the formation. The earlier folds were not formed penecontemporaneous with sedf wentation innatuch as quarts lemes of wetamorphte ortgln are sinllarly folded.

In come areas minop folds are found in thrust fault sones wh axes pargllel to the thrust mor enent. Ihose are balle red to be formed by difforontial and diverging moroments of individual rock wassos within the fault zone (Balk, 2936, p. 738-739; Fairbalm, 1949, p. 222). Balk (1952, p. 418) Ind1cates that folds parallel to the direction of norem sent assoclated with thruets are omall "with wave longth mearured in Incher rathur than in foot ${ }^{B}$ and that moet of ther are noariy 1ooclinal. A. a reault of detalled structural studies relating the finor structures to thruat blocks in the Bergadalon quadrangle Kvale (1947, p. 205) concluded: "In metamorphic rocks the Ineation which represent the direo- 
tion of least resistance may under certaln conditions bo formed at any angle with the principle wirection of noverent of the roks."

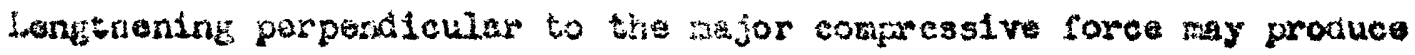
plunglng folle, ebilonts, or recesses. The devilopment of such foutures is accompanied by componenta of extension parallel to the major fold axes in a given roek layor (B111ings, 1942, p. 234-239; c100s, 1946, p. 26-29). This component of extension may causo folds or crinklos at a largo engle to the major fold axas-and Bubsrallel to the direction of eovent. These rolds ms form by the actual buckling of a rock layer with greater competancy than tho surrounding rock (Kuonen, 1938; Godfroy, 1954) or by the drag produced by differential sxtension in ajacent rock layere. 01003 (1946, p. 27) Indicates that this process should be partioularly affective in incorpotont rocks and that the folds produced should be of a gall order of ingnitude in comparison with folds resulting from the tajajor nowge direction.

Irregularitles in the "batont rocks" or the presence of intrusive rock masses wight also be respensible for devlations frow the for flowage direction on the 24 b of a fold or micht cause shortaing or extenslon parpendi cular to the major compressive for oee.

Brace (2953, p. 68-72) has described folds siallar to those in the irde Park quadrangle parallel to a etrong stroaning and to cobble olongaEIon and aubporpondieular to major fold sxes on the east elank of the Orsen bountain ticlinorlum in the sutiand giactrangle, Vermont. vio con3 ldered that they deviloped subperpendicular to the rojor fold axes during the formation of the Grean Mountaln anticlinoriun. "whereas the com- 
inant corement during the daformation was in an ast-west drection ...

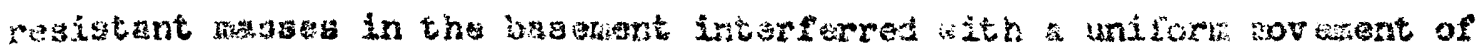
Layarac unita watward up the astarn liab of the anticlinoriua (inace, 1953. P. 69).

No thrust faults were found within the hyde fark quadrangle, and it is not belleved that all the characteristics of the first stage minor structures could be produced by thrust falt 3 . It is belleved that when the Groon Nountein anticlinorlun flrst bagan to form that floxural slip occurred along the stratiflestion $\left(3_{1}\right)$ causing the seoundary bedding foliation $\left(S_{2}\right)$ to form. Plunglng fold and recesses devaloped (see plate 4 ), indicative of extenston farallel to the fold axes, and winos folds form os. nearly at right angles to the axis of the Green Nountain anticlinoriue. Further flexural alip wa secomodated by ollp along the bedding follation $\left(s_{2}\right)$, by rotation of the folds $\left(L_{2}\right)$, and finally by shearing or strotching off of the fold on their short limbs and fold crests. The planes along wich IIexaral a Ilp oceurred in the stage of the deformation wore generally perallel to the bodding but locally transected the bedding. The actual folde $\left(L_{1}\right)$ ware formed by extension nearly parallal to the axis of the Greon Hountain antlalinorium, but they are rotated and tightened and the transvares schistosity $\left(s_{3}\right)$ wa formed by ralative movement between the layers noarly at right angles to the axis of tho reen hountain anticlinorlum.

Furtber flexural slip caused crinkles and folds $\left(I_{2}\right)$ to form aubparallal to the axis of the Groem kountain antielinoriua, and oventually causod the slip clearage, slaty follation, and schlatoolty $\left(\$_{4}\right)$ to formo 
The latest folda $\left(\mathrm{I}_{3}\right.$ ?) and tho ralated rracture elenvage $\left(\mathrm{b}_{5}\right.$ ) are probably not directly related to the fon bation of the ineen hountnin antclinoriun. 


\section{Whatholis:}

\section{Genoral statenent}

ail of the rocks of the ifyle rark quadrangle, except she post-matanorphie dikes ha ve been affected by rogtonal netasorphiata. Differant assembleges of minerals are stable in rocks of a given chemleal composition under different conditions of etamorphisn. In this area chiorite, aliandite, and kymite are accessive ganeral inde ators of increasing metamorphic grade in the sralleceous and arenaceoas rocks. Chlorits, actinoifte, and hormblonde are olmilar indicators in the wefie rocks. Tho mineral a aseablages noted in the rooks of the Hyde Fark quadrangle will be described in detall and w111 be used to determino the succesalve alneral transformations wich occurred during the motamorghtem.

\section{Hinerelogr end petrozrantr of the sentet}

Detimated modes of typleal fock typoe are tabulated with the descriptione of the Individun stratigrephio units. surts, "serielte" (both maveovite and parazonite), chlorite, and albite are by far the dowinant alnerals in all the netasodimontary fornations, and there is a wde range in tholf relative propartians. Surt ranges from 0 to $n$ percent, "sericiti" Irom 2 to 70 parcent, chlorite from 0 to 40 percent, and albite from 0 to 40 parcent. ivven within atngle farmation the range In the dowinant constituents is rary great. Almandite, kganite, Eraphite, calcite, ankerite, blotite, and magnetite each constitute a wuch as 5 percent of some rocks. kinor minorale include tourmaline, spatite, pyrite, 1teonite, rut110, 1lmentte, sphene, allante, zircon, 
and elinoxolasterpidote.

AII of the einerals occur in bolte cheracterlstic of thatr occurrance in los-grade and middlo-grad schlats and no totalled discusolon of Indivldual habit is moceseary. In general the grain ine of the major constituents increases with the gredo of tamorphism.

Graphite, 21monite, and pyrite conaconly ocur together, producing the characteristie dark-colored, rusty-weathering outcropo of the graphitic rocks. Jacobs (1938, p. 52) roports 1.09 welght pereent of carbon in arsphitic achiat Irem hyde Fark town. Analyoes of carbonaceous shales show a sulfide content appreatably higher than that of nonearbonaccous abales. The sulfide content, the carbon content, and the forrous nature of the Iron all probably are primarily due to atrongly reducting conditt cons at the time of deposition. Those rocke in witeh ragnotite

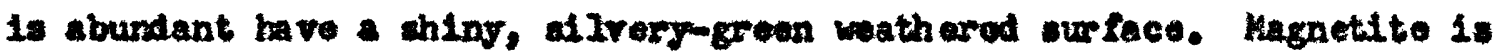
not found in the graphitic schists, probably dae primarily to the $10 x$ ferric Iron content of carbonaceous sedinents and pos sibly due in part to reduction of forrio lron by carbon during wetaworphtam.

Forrie minarale $+\mathrm{C} \rightarrow$ Formous dinerule $+\mathrm{CO}_{2} \uparrow$ Hereover the chlorite in the graphit 10 rocke comenly contalns less forwous Iron than gnestum, es ind leated by a positive optio slgn, a negative elgn of elongation, and lov ind ox of refraction (see Fifure 4 ). Inacwerch as analyees indie ate comparable total ir on cont ento in both carbonsceous and noncarbonaceous abales, It soens 11 kely that the low Iron content of the chlorites in the absence of magnetite or blotite is rolated to the high pyrite content of the eraphitic rocke. 
The grophitic rocks commonly contain shene, will mom-graghitic

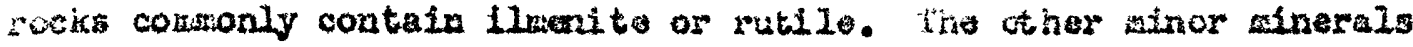

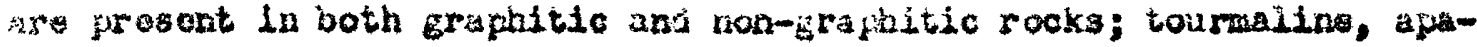
tite, and clinosolsitemoplute bedng prosent in nearly every thin secm tion.

Snall whedrel crystals of aleandite garnet enclosed in large porphyroblasts of albite have been noted in the cosrso-grained schlst of the Camels Hump group in the western part of the Hyde Purk quadrangle.

The varlou assemblages hich have been noted in thin sections are cabulated In Table 21. Dr. Hans tugster of the Geophyaleal Laboratory, Carnegie Inatitution of hashington, kindly idantifled wary spoctuens of

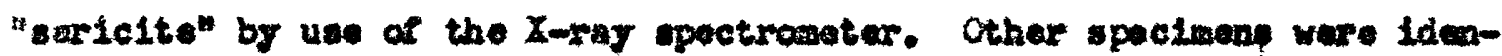
tifled by the author. Both macovite and paragonite ha ve been 1dentified, but no pyrophyllite was found. In some apedmens as much as 55 jercent of the "perletio" is paragonte.

the lron and magesium content of the chlorite has been interpolated frow the optic indices. Winchell (2951, P. 385) abi Heg (1954) bave pubIished graphe for this perpese, but it was folt that it would be bettar

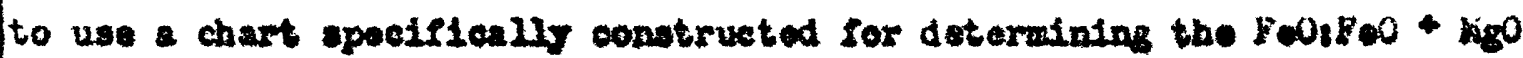
ratio of chlorite from low-grade and mLdile-grade wetanorphic roeks.

Although the optic indies of chlorite depend nost atrongly upon the

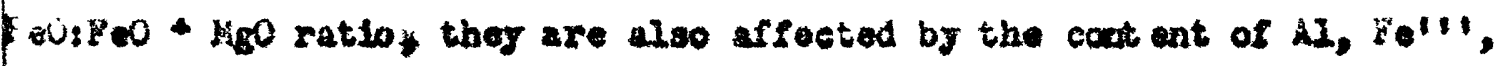
1, fin, Cr, etc. It seans probable that the varlation of these componprits 1o more reatricted in chlopites of low-grade and middlemgrade motaporphic rocks than in chlorites as a wolo. Thus, a dagran relatins tho 


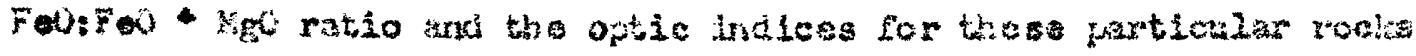
should be wor accurate than one preved for chlorits in gonord.

The Ideal stractural formis for phninite indicated by fauling (1930, P. 578) 1s:

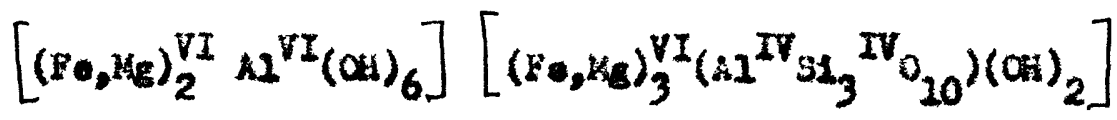

However, most matural chlorites have an excess of alumina over this for-

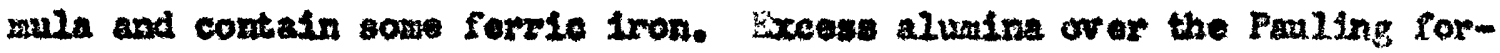
min way be divided equily botween the alx-fold coordination and the fourmold coordination poultion in the following fachiom

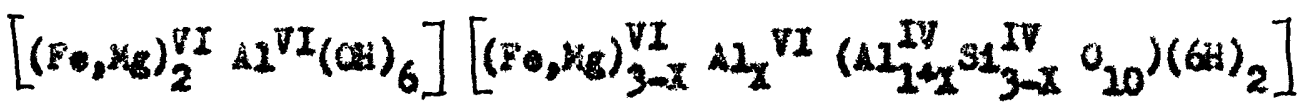

Forrio iros in sx-fold coordination ma be compenated by aluedn: ontering four-fold coondinution in place of allicon, or my result from oxidation of ferrous bron and 208 s of wates (inche11, 2926; liey, 1954 ). About 55 ahlorite andraes, irom publinhed and unpubliahod sources

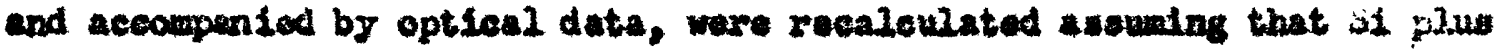
\& (Foll + Al"1) $=4$ (mole proportione). It was found that 1 (Fo'll

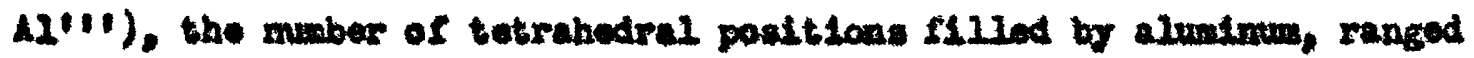

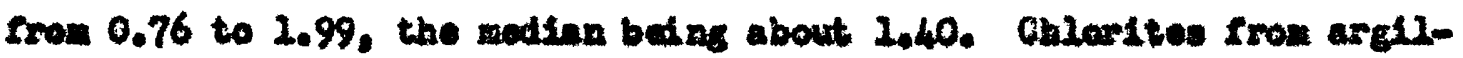

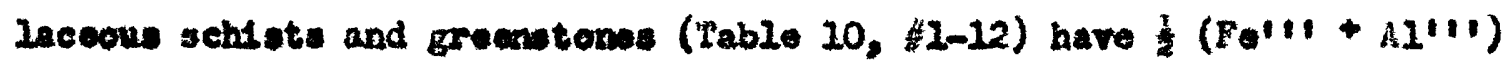
rangtne from 1.27 to 2.63 , the lower range coulng from greenotones and the thger range frow argilleceous schilts. The bonds in the ahlorite

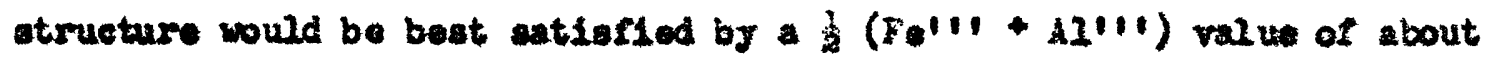
1.33 (J. B. Thompon, written communicaticn). kost value above that flgure are from ahalyees of chlorites esparated fros argillaceous 
schiete. It is poesible that leperfect apparation of macovite ray bo

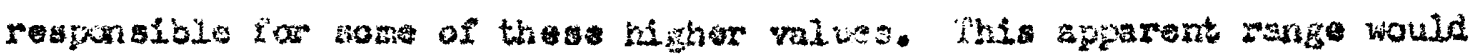
be reduced if part of the farric aron la dus to the oxidation of rexrous fron. Othar chlorites (Table 10, 13-42) were chosen for a low forric Iron cont ( $109 \mathrm{than} 3.5$ welght percent) and a linited range of values of $(F e l l+A 2 ' 1)$. For wach of these

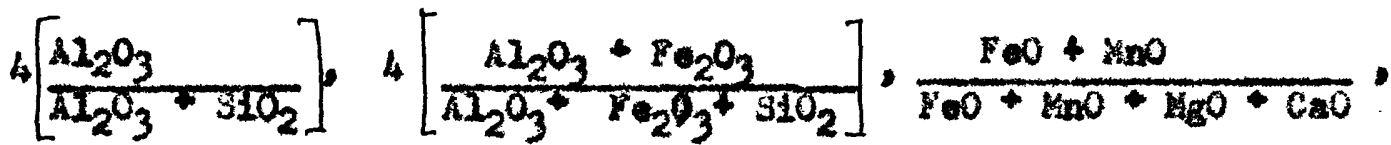

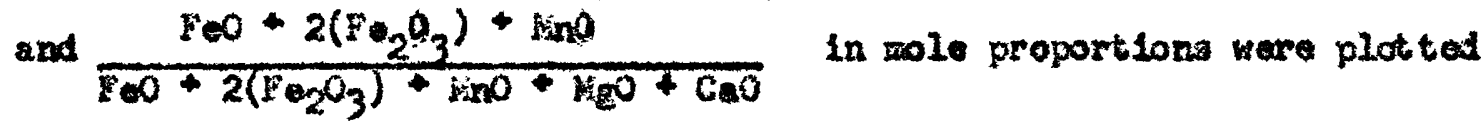
against the $Y$ index of rerraction. The factor of four bas been added so that the ratio fives the mabor of al"' atom in four-fold coordination; the ralue can then be oubatituted directly into the chlorite formala. ixantnation of Figure 3 indicates that the Iron cont ant is ohloriy responsiblo for an increase in the opt10 ind 10 as and that the deviation from atrulght Ine is Ittle groater then the orror in the determinetion of the optie indicos. The effect of a vartation in alunina and fortic Iron within the range oonsidered is apparently lees than the vartatlon due to the coablned anditteal and ind cx doteraination error. Yoder's (1952, p. 576) aynthotic pure mgnealua ohlorite has a Index of 1.580, Iying upon the curve.

The optic sign changes and the birefringence passea through zoro at a I Index of about 1.627. On alther sid of the s1gmehange abnornal Interfarence colors are visible. The low index alde (1.e., ragnesiumrich) has a positive sign, a negative algn of elongation, and abnormal 
Figure 4

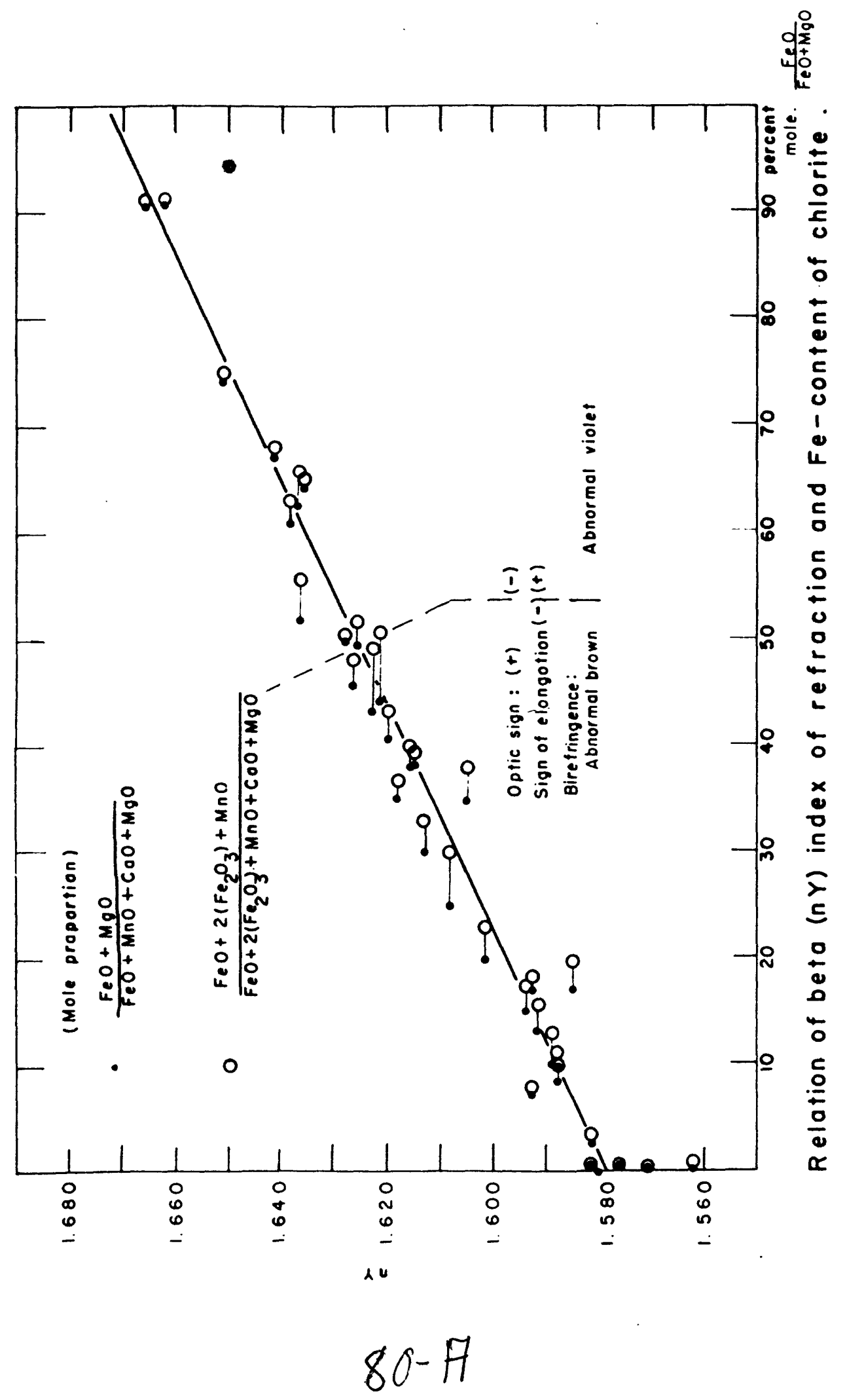


Figure 3

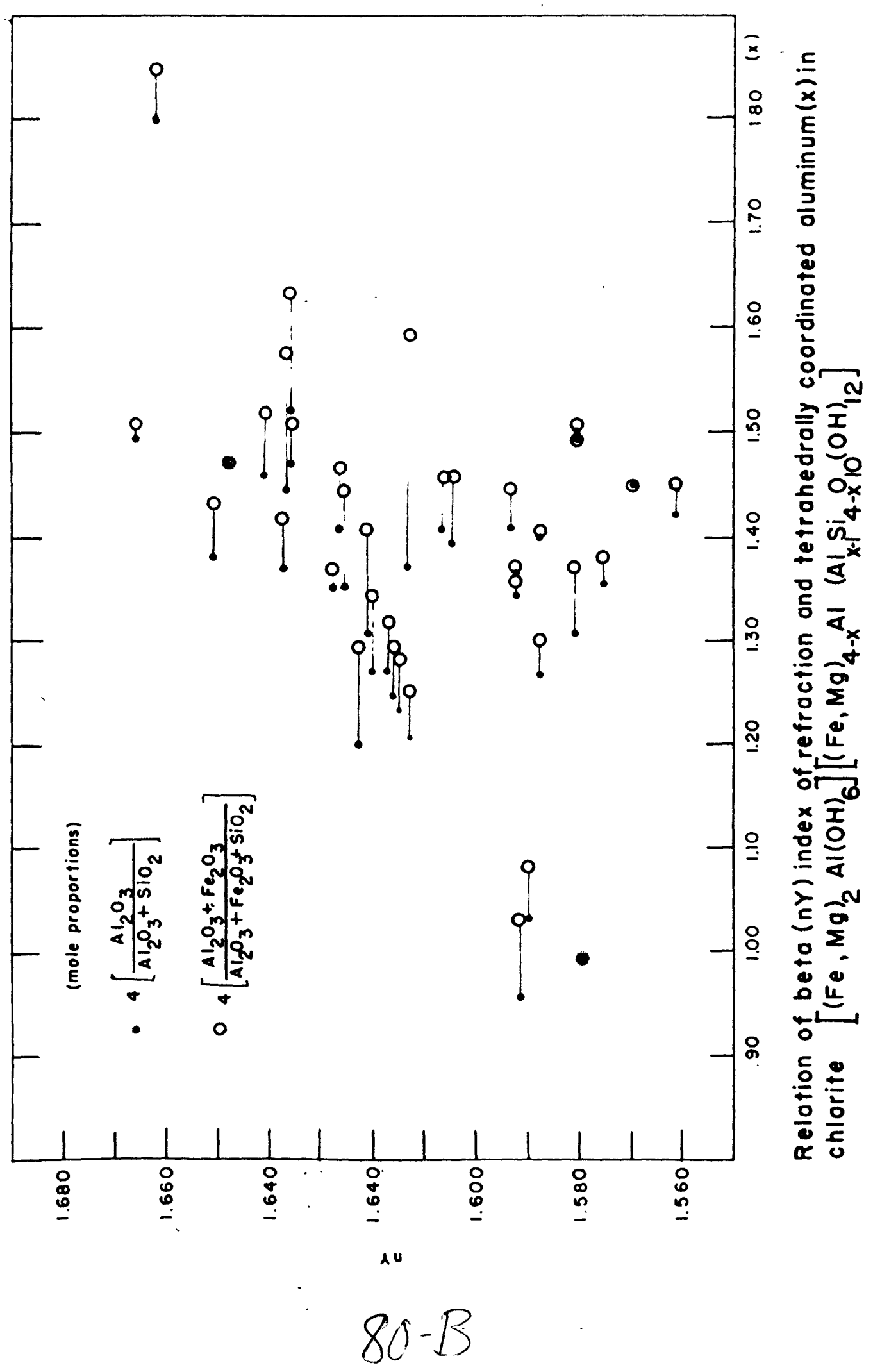


brom Interference color, the birefringereo lncreasing with increas ing magnosium content. Tho high indax alote of the sim change (1.0., ironrich) has a nagative sign, a postive gign of alangaticn, and abnomal viol et intertorence color, the birefringence increasing witb increasing iron conteat. This point corresponds rary closely to the ofmilar polnt on winchell's chart (1951, p. 385), but not to Hey's chart (1954, p. 284). A aimilar $\$ 1 \mathrm{gm}$ change has boes noted at a Index of 1.575 in "chlorito" from altramafie body in Lowell, Vermont. Howover, theae have not beea positively thowa to be true $14 i$ chlorlto.

In. fow thin sectione chlorite gratns sosociated with Ifronite stov peripheral alteration to yellow-brown, wore highly birefringant atueral, boaring a Fowblanoe to stilpnowalane. I-rar investigntion fallod to show the prosune of otilpnoselane and it was concluded that the alteration $i$ the reavit of cocidation of forrowe iron in the chiarite, probably durling weathering.

The content of Iron and wenealun in blotite has been atinested from rafracti ro indlces using the chart of finchall (2952, p. 374). Very fow andyes of blotite from lowmgrade or atddlomgrade cohista are avallable and the follonding formula argested by $J$. B. Thorgon has boen laed as representing tha nost likely alumina cont ent of the biotite.

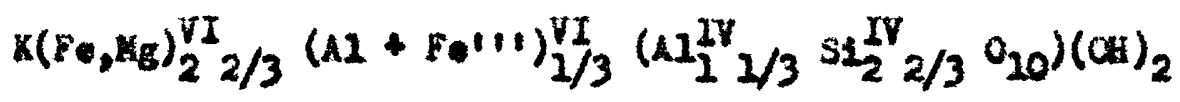

The variation in the lron and gnestum cont ont of chloritoid is apparentis mall; eeven specinens had a I Index of 1.720, two had a I index of 1.719, and one hed a I index of 1.718. A typteal specimen had 
The rollowing optical characteristics:

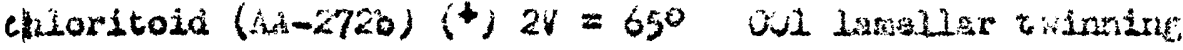

$$
\begin{aligned}
& n i-1.717 \\
& n I-1.720 \\
& \text { r.2- }-1.727
\end{aligned}
$$

Apalyses of chloritold from other localt los sugest that the indices

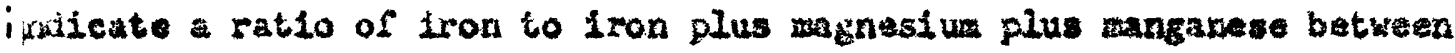
.80 and .90

The schists in the kyanlte and garnet zones show rotrogrado alteram fon. kyanite, zarnet, and blotite are partially or conpletely altered to aucovite, chlorite, chlorltold, and manetisa. In aw thin sections only a paripheral alteration of kyacite and garnet grafns was noted. Yore costonly, fine-grafned aggregate of suscovite with coarser plates of chloritald encloses irregular rellet prains of kyanit, which are in parallel optiesl orientution. The chloritold plate are consonly oriented in rosettes. $51 x$ gpedmen of altered kjanits proved to contein miscovite with no paragonite of pyrophyllite. Flne-gralnad agsrogates of chlorito, clorsonly with saricite, magnotite, and rutt2e, onclowe garnot ralles. irreguiar rellet gralne, whith are in parellel optlenl orientation, of ciberse muscorite in a fino-grained agerezate of sarialte woro also notad. In other thin cections the fino-grained ageregaten are present in a rock contalnting coarso-gralnad wascovite and quarta, but no rellet erains of Kyantt or garnet have been preserred. No pseudosiorphs or relict grains of staurolite or of sillimante htre been noted, but several thin sections contain irragular plates of 


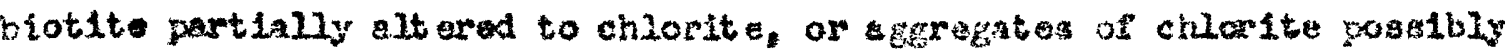
7roudomorphic after blotite. Some ohloritold is clearly an alteration product, but it appears to be part of the origtmal asemblage in othor spoctinens.

\section{Eetrologr of the misecent sohist}

Zones of progressive roglonal metarorphica

In 2893 Barrow, woriding on the Salradian schists of Scotland, ped zones of progresaive reglonal etamorghism. These zones were based on ineralogical transforations in derivatives of argllaceous sedinents and were correlated in a goneral way with inereasing teaperature and pressure. Each zone of progresstre waturorphise me defined by an index Anerel, the first eppearance of which (In pasalng frow low to highes grades) marks the outar 24utt of the particular zone. The trace of this purface on the earth's surface was termed an leograd (IIne of equal metatarphle grade) by IIlley (1925) and was intarpreted by both 1111 ey (1925) and Harker (1932, p. 186) as belng aleo an 180therm. Since the occurtonce of a mineral depends in purt on compes ition, it was reoogmzed warty that rocks of comparable cheleal composition mat be salected for tonsl mapping in tarms of index winorals. In man areas paltite rocks 1 have been chosen because of thetr widesprend occurrence and because of the numorous mineral changes which take place in the with increasing migtamorphic grade. The zonal sequences chlorite, biotite, almandite, staurolite, kyenite, and sillisenite (In order of incroasing notasorphic grade) - is typical of many areas. 


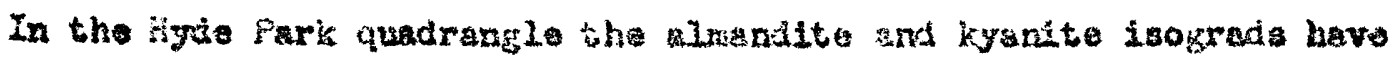
boen wapped on the basis of the first appearance-that is, tho garnot laograd surround all occurrences of garnat in arglllaceous schlst, te. The gernet and kyanite wnes are confined to the southeset cerner of the area, Iylng entirely within the stowe formation.

In the Kt. Nansfield quadrangle blong the crest of the Green tountain anticlinorium and juat west of the odge of the Hyde Park quadranglo garnote ware 8180 oberved. Futherace, six thin sections from the coarse-grelned schlst and gnelss of the Canels liusp group. Iring on the weat side of the ares, contalnod sull euhedral porpkyroblasts of gernet within langer alblte porphyroblasts. Many albite porphyroblats were rotated and the texture of the rock modifled after the porphyroblasts ceased their growth (page 68). It 18 bell ovd that the anall garnots are a rellet fenture, all garnots not protected by albite having been altered to chlorite. Ints implies that the garnet epo orignalif covered mach wore of the quadranglo then bown an the mep, am that the rotrograde iteration has destroyod nearly all evidence of its exiotence.

A blotite isograd ha not been sapped within this area. The paucity of blotite and the abualanes of chloritoid in this ares proupted the author (AIbes, 1952) to calarlate muserous andys of of arg111aceousarenuecous sedingents to determine what siners lo would be present if the sedineat wore metarorphosed. It was found that the range of chenteal composition is such that many argllaceous sedisonts would not contain blotite unt1l the garnet, kyanite, oren the silleante wone of metaBorphtan. It was also found that many of the arelllaoeous rocks that do 
not contain blotite should contain chlo:1toli. The prosence of chlori-

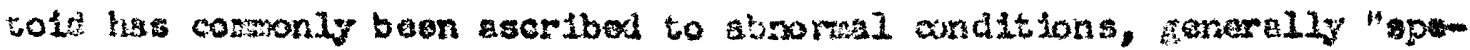
cial pressure condition" (og. Barth, 1952, p. 336). However, invest1zation of the chenleal compoltion has de it clear that the presenos of chloritold and the abaeno of blatite in arglilaceous rock of low grade arees such as the liyde Park quadrangle 1s not abnornul; it is due to a compostion different, but not anowlously difforent, frow that present in sross in wioh the blotite zone 18 woll defined.

Petrology of the meaceous schlats of the Iyde Park quadrangle Introduction.

The retrograde alteration of the rocks of the garnot and kyonite zones be de It Impos alble to deternine the exact aequence of mineral transformations in this aree. The sequence presented here is based in part upon Invertigat Lans in the Lincoln Nountaln and Hontpelier guadrangles and upon general monledge of lowmgrade and middle-grade minsral assemblages. The ninerel asemblages noted in the chlorite, garnet, and kgant te scaed are presented in Table 21.

It It conventent to wow the observad afreral asacublages diagrammat1cally. N1ggls (1954, D. 391-403) and Thompson (unpublished lecture notes) have discussed approdmations in accortasee whth the phase rule

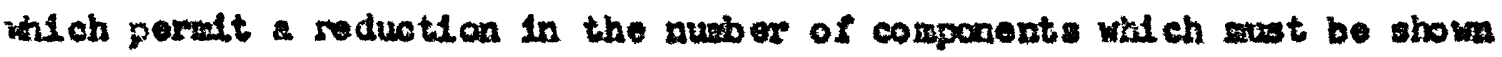
graphlealiy. Such diagrams "fecliltate the obtaining of a first comprohenstre riow," "alds the discusaton of the posalble relat lonships of the phase ang themelves, "are useful aid to viuualizetion," "belp in 


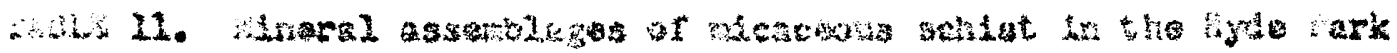

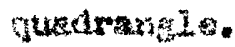

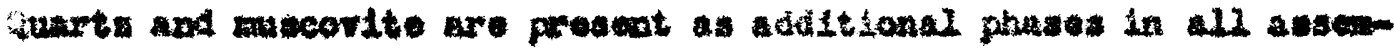

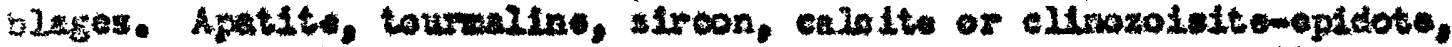

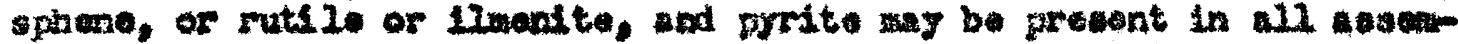
blages. Armoured graine of two of more titunium minerals are comon.

\section{ctantre 200}

albitomaphite

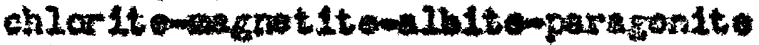

chlortto-agnetitompragonito

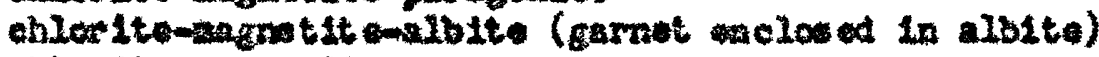

chloritemangatite

oblarisonalbitemgraphite (garaes in albite)

chloritomparanite

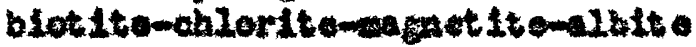

blot Ite-chlorl bemalbit onjraplite

chloritoid-chlorsto-menotite

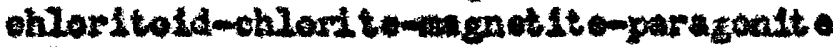

chloritola-ohlorite

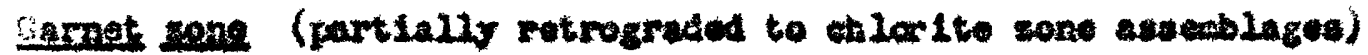

chlorttomingnotitrmaldte

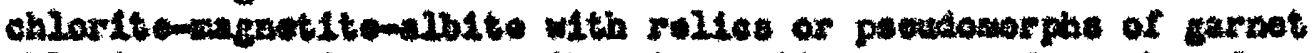

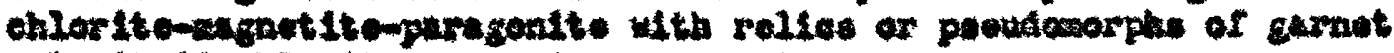

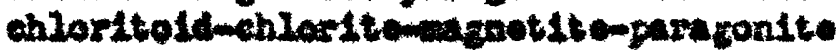

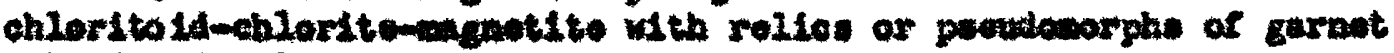

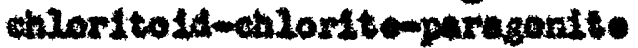

chlor 1 bold-menot 1tompregondte

chlert teld-parageat te

chlowitose

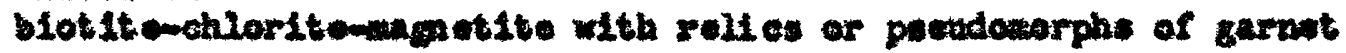

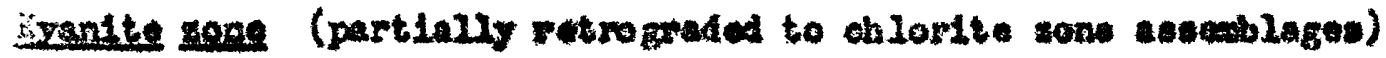

ohlorttemenotite with ralles or peudorerphs of garnet and loranite chlorite with ralles or perutowerphe of garnot end kyentte

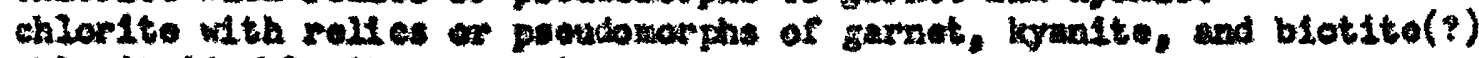

chloritold-ehloritemagrits.

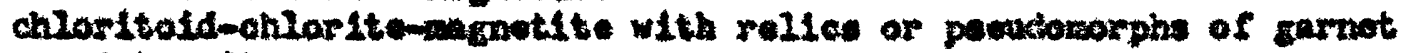
and krantite

chlariteld-ehlorlt with relles or pevidosorph of garnet and kranite

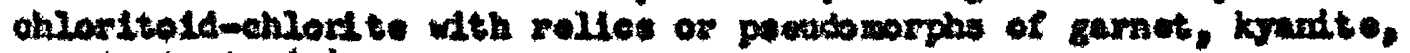
and blotite(?)

blotite-obloritemagnetite wht relies of gannot

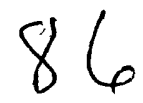


TABLB 12. Optieal dats on chlorite, blotite, and chloritold

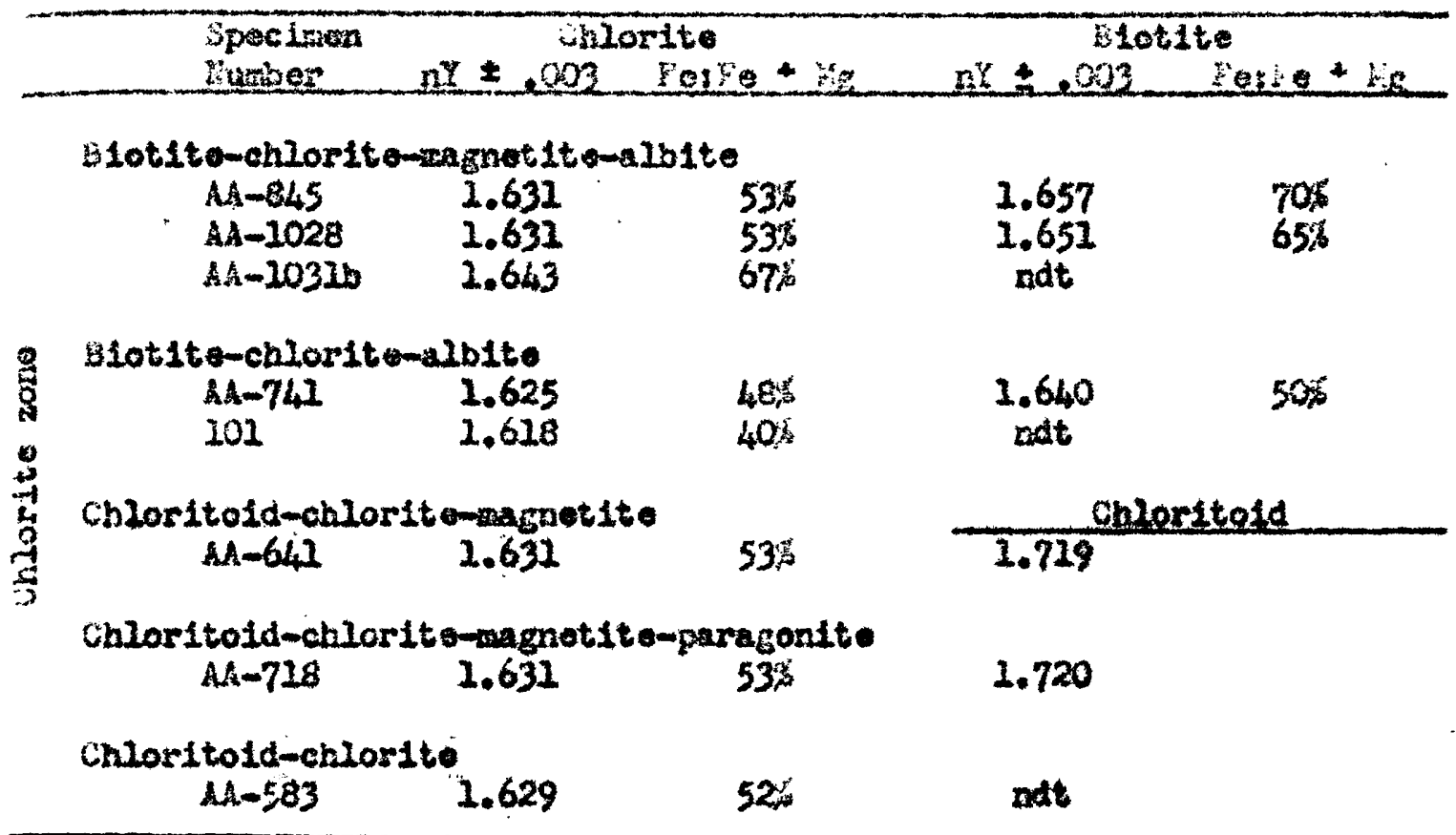

Chloritold-chion it e-mignetite-paragondto Ah-535. $2.626 \quad$ rat

Chloritold-chloritomagnot it wh ralles of psevdoworgh of garnat $\begin{array}{llll}A A-30 & 1.632 & 536 & 1.720\end{array}$

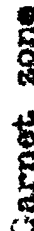

Chloritold-chlorit -paragonite AA-272* $\quad \mathbf{1 . 6 3 5} 58 \%$ nat

Chlort told-magnetite-paragenito $A k-82$

1.720

Chloritold-piragontte $14-272 b$

2.720

Biotite-chlorf temagnetite vith relles or pecadoworphe of garnet AA-239 $\quad \mathbf{1 . 6 2 9} \quad 52 \%$

Chloritold-chlor lte-magnetite
$11-22$
1.621
$43 \%$
1.729

Chloritold-chlorlte-megnetite with relics of pseudoworphe of zarnet

$\begin{array}{llll}A A-106 & 1.625 & 48 \% & 1.720 \\ A A-231 & 1.631 & 53 \% & 2.720\end{array}$

Chloritold-chlorite with relice or peeudororphs of garnet and hymite $\begin{array}{llll}1 A-20 & 1.615 & 37 \% & 1.720\end{array}$

Slotite-chlorite-magnotits with relles of garnet

$\begin{array}{lllll}A A-75 & 1.623 & 45 \% & \text { ndt } & \\ A A-1100 & 1.625 & 48 \% & 1.643 & 55 \%\end{array}$


correctly formulating the proble exountered," and "fulfill the inporisnt function of diseouraging the puraly a culstive appos ch and curbing

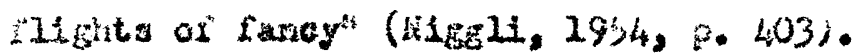

The argillacocus schists contrin phases which to a first approxdwe-

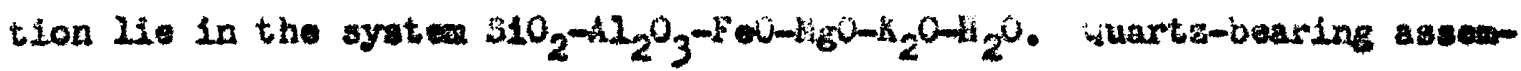
blages in this ayete bo shom graphieally in a tetrahedron with the

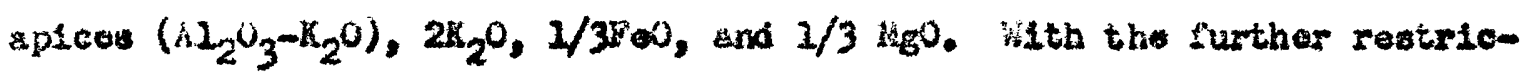
tion that muscovite bo prosent the assemblages may bo projected onto a plsne; graptically a projection through nuscovite to the plane betwean the $\left(\mathrm{sL}_{2} \mathrm{O}_{3}-\mathrm{K}_{2} \mathrm{O}\right.$ ) apox and botito (soe Figure 5a). In wuch a projoction the composition of the phases may be located as shown on Figure $5 b$.

In accordance with the phase rule the three phase asaemblages in the above diagram may contain one additional phase for each of aeveral other components wuch as $\mathrm{Na}_{2} \mathrm{O}, \mathrm{CaO}, \mathrm{Fe}_{2} \mathrm{O}_{3}$, and $\mathrm{THO}_{2}$. Two phese assenblages on the diagram may contaln two additional phases for ene of these other components. Such phases in observed ascomblages may bo noted on the disgram.

Tho diagrams show on F1gure 6 show the mineral assemblages found at successfrely highor motamorphio grades. These are based upon the observed assemblages given in Pablo 11 , the laterpretation of the rotrograde taxtures, and upon assembliges found in nearby aroec. Assomblages that ware actually observed in the Hyde Fark quadrangle are connocted by solld lines and the ros fof res ratios of biotite and chlorite that were determined optieally aro shown with solld circles. 
Explanation to Pluares 5 and 6.

The construction and the comers of the triangular diagrane in Figuro

6 are ahomn in Flgure 5. Each Alagram represents the minemal acoesiolage otable vith quartz and masorito over a linttod ruge of $F, T$, and $\mu_{\mathrm{H}_{2}} \mathrm{O}^{*}$ Paragonite is prosent uth as seablaces abowe and albite vith ascowiagen belew the beary danhed line In ILguea $6 \mathrm{~b}$ and $6 \mathrm{c}$.

Minaral acsemblages actually obserred in the tride Paxk quadranglo are thom with solld lines. For these assemblage solld olreles

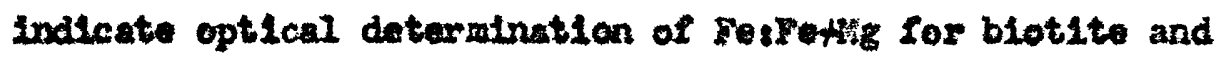
chlorite. Hollow clrclos inciteato a rablable Fath ratio.

\begin{tabular}{|c|c|}
\hline$A 1 b$ & alo1to \\
\hline An & elmandito \\
\hline Bito & blotito \\
\hline al & chlors to \\
\hline$c t a$ & chloritold \\
\hline Kao & kaolinite \\
\hline Kap & potassiun feldepar \\
\hline nt & lganite \\
\hline He & muscorite \\
\hline Par & paragonite \\
\hline $\log$ & prrosinylu1to \\
\hline
\end{tabular}

$$
88-17
$$


Figure 5

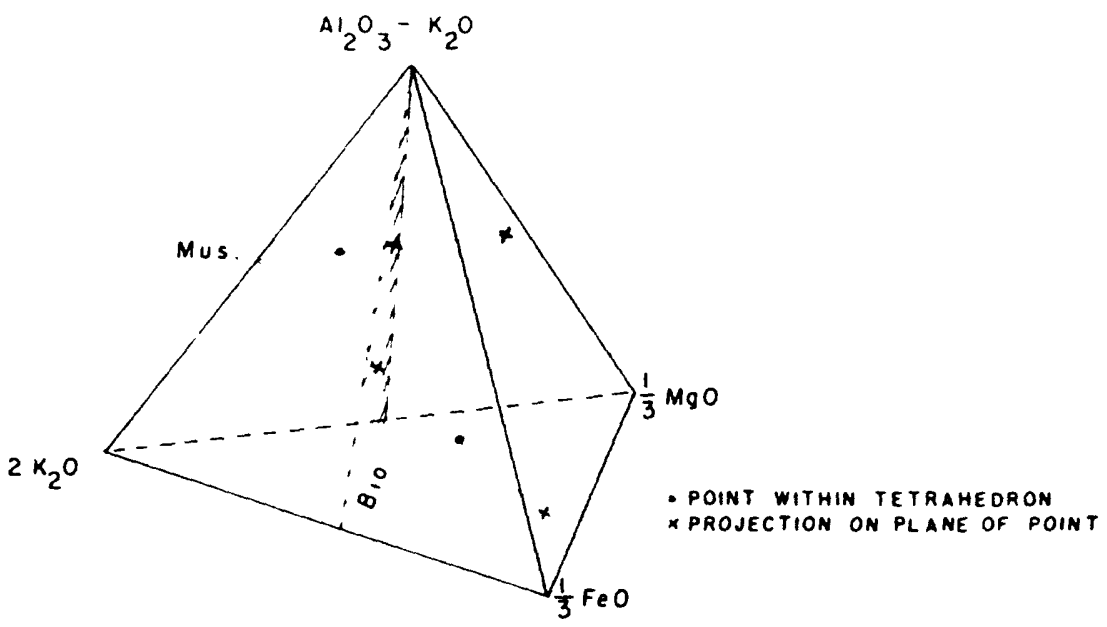

(0)

Location in the tetrahedron of the projection plane used to show phase assemblages of quartz-and muscovite-bearing schist

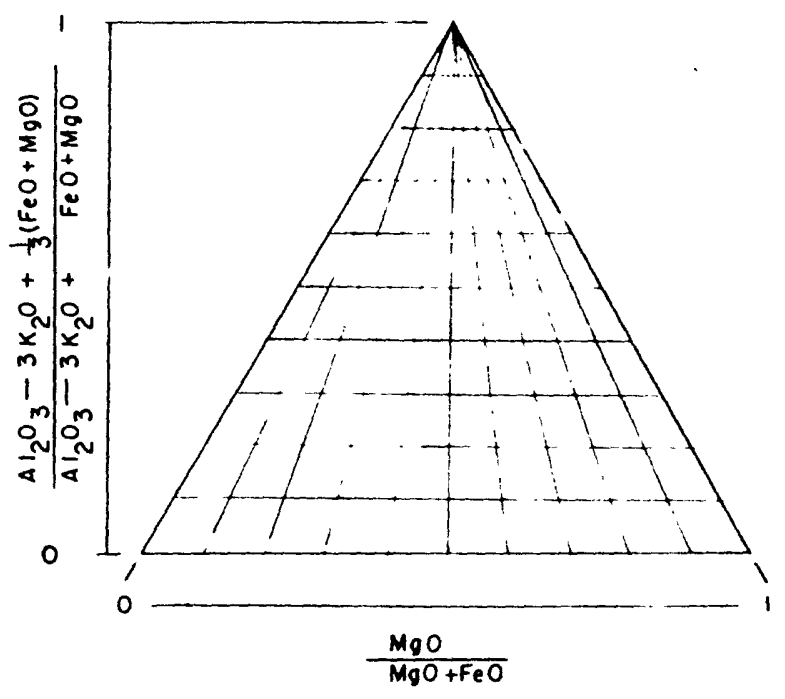

(b)

Method of locating composition of phoses upon the triongular projection plane

$88-B$ 


\section{Plegre $6 a$.}

The assemblage elloritemuscovite-quarte is very coman throughout the center of the lyde park quadranglo. Lit ray in part in this wrea be an assecblage of the chlorite sone prior to the appearance of chloritoid or blotite, although the esemblage does poraist into higher metamorphic grades.

It oesws Iikely that chlorite is ane of the firat stable ainaralo

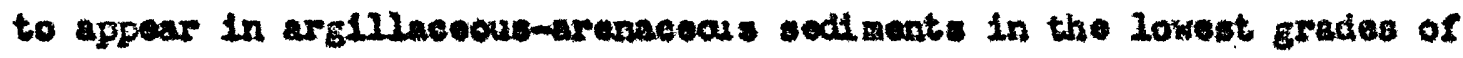
motanorphim (diagenesis). The variation in the wluedrum content and

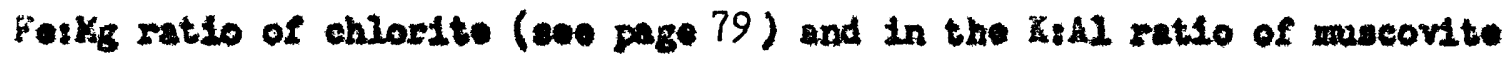
(Yodor and Eugater, 1955, p. 257) is great enough that the maseoritechlorite fiold on PIgure 6n Includes the composition of the most comon sheles. In addition, if axgen is "mold 10" (Thowpwon, 1955, p. 81), the

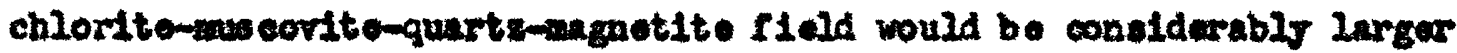

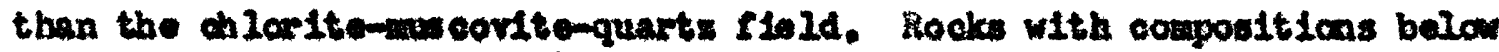
the muscovite-oblorite joln comeong contain grains of potaselum reldspar watch are apparently of detrital origh. It night bo assumed that such rocks rotaln the dioequilibriue assemblages of the sodiment, but chayee (1955, p. 80) has ofted orldeace for atablo potassium foldopar-chloritoasuscorite-quarts assumblage. Hocks with composittions above the meseovitochlorite join wy contaln kaolinite, alunimumontworillonite, or prom phyllite, bat X-ray work on semples from the Hyde Fark quadrangle and from northwest kalne have not yot confirmod thlo. 
Enura 69.

Although biotite is unsowan both inlorito fo-chlorito-mus covitequarts and bictito-ehlorito-auseovito-quarts assembinges are present in the Hyde Park quadrangle. Chlorite is higher in magnestum than ita com bxisting chlordtold or blotite and the trends of the tle Iines in the two phase rielde are Indicated on the llagram. There is no oridence as to whether blotite or chloritold formed earlier. A careful search of the Ltorature and of apecinens in the harrard collections disclosed only four occurrenees of chloritold and blotite together; moreover, several df these may be disequillbrtum assemblages. This suggests that the

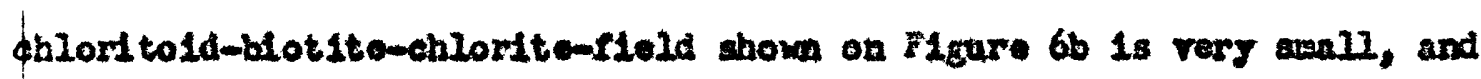
to be found only in rooks with an umarally hith reoskgo + Foo ratio. It 1 also posable that the chlarite Meld cute it out until just prior to the formation of garnet. As indisated on the dlagram both paragonite and inite are foum with the chloritemumeovite-quarts assublages but alblt is not fond with ohlowitold and paragonite is not round with

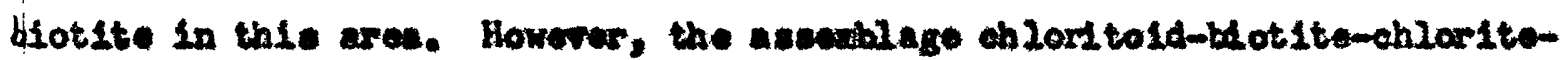

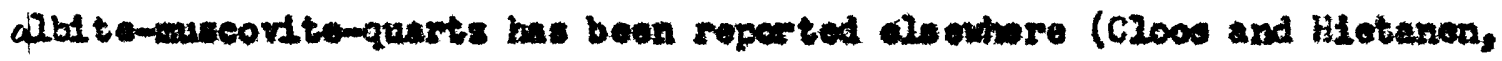

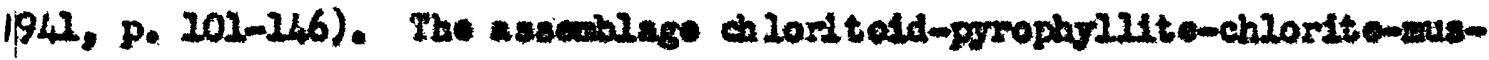
covitemguants is uncomon in bedded rooks, and it is belleved that kaolfnite rather than prrophyllite probably paralsts into this grade of metamprphiso. 
Exure 6c.

This diagram is markat by the appearancs of aluandte garaet. In the garnet zone in ine coutheastern part of the area garnet-chioritold-chlorite-quartizuscorite to have been the stable assemblage at the peak of the motanorphism before the retrograde ltoration. The semo asmesabe is coksnon in the Incoln vountaln aren to the south. Also in the same area garnet-chlorite-blotit a-muscorito-guart 2 is an assemblago cokition in otratioraphic units whis contain chlor 1 to-elbitemacorite-quartz or chlarito-biotite-albit emuscorit o-quertz in the Hyde Fark quadrangle. Ono spoctmen of the latter assemblage did contaln anall garnot porphroblants onclosed in the albit graina; frobably as armoured relleb (page 84).

If the biotite-chloritold-chlorite fleld is prosent the transition frow Mare $6 b$ to Yigure 6 1s:

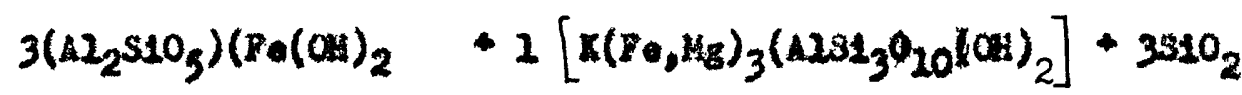

$$
\begin{aligned}
& \text { ohloritold } \\
& \text { blotite } \\
& \text { quart: } \\
& 2\left[\mathrm{~F}_{3} \mathrm{NZ}_{2}\left(31 \mathrm{O}_{4}\right)_{3}\right] \\
& \text { slanendite } \\
& +2\left[\mathrm{Fu}_{2}\left(\mathrm{ALSL}_{3} \mathrm{O}_{20}\right)\right.
\end{aligned}
$$

\section{In thi
would
gramo}

When the flald chloritald-chlorito-blotito-muscovitomuartz does not appear nearly 1socheleal transition of 1rop-rich chlorito to almandite it indieated by the common compositione, a compared to the ldeal roraulas, 
of chlorit and blatite. Comonly the aluntaus conturt of chlorite is hat onough that the rollowhe transition ean occur nosply lachonically wth rery little dotita baing raed.

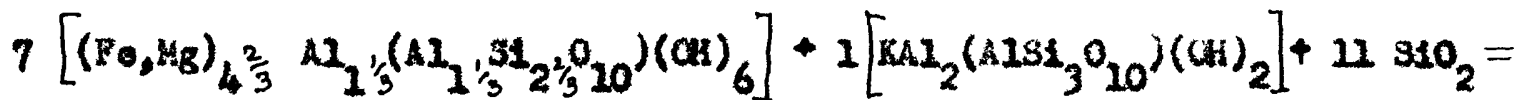
chlorite muscorlte quarts

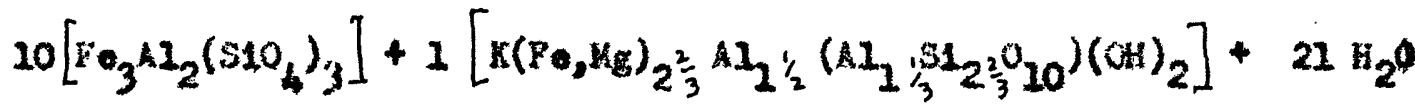
almand1te blotite

\section{E1:ure 64.}

The nest transition would probably be the appearnace of kganite. The flolds would probably remain similnx to Flgure 6c, axcopt that kganite would sppoar in place of kaolinite of prrophilite. These tranitions would bes

1 proptalute $\rightarrow 1$ kqanite +3 quarts $+2 \mathrm{H}_{2} \mathrm{O}$

os

1 kaolintte $\longrightarrow 2$ kgante +1 quarts $+2 \mathrm{H}_{2} \mathrm{O}$

The s1ze of the kganite-obiorl to 1d-chlorite field would probably not change too mech frow that of the keolinite (or pyrophyllite)-chloritold-

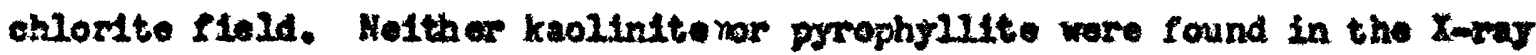
work. Thus, it is beli oved that the kranite sone as mapped in the hyde Park quadranglo is reprogented by the next diagram and that this firet appearance of kgante would be rare or absent. 


\section{Figure 6o.}

This stage is sarked by the presence of kyanito and garngt as conpetible phass and the incompatibility of aloritold and ohlorite. ine transition fros Fifur ba to F18ure bo 18

4 chloritold +1 chlorlte +4 quarts $\rightarrow 2$ kyanite +3 almardite $+7 \mathrm{H}_{2} \mathrm{C}$ interpotation of the retrograd textures suggests that kyandtemamet-

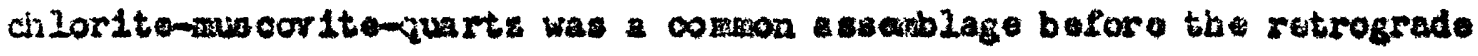
alteration. There is no suggestion in the taxtures that stauralite was arar prosent.

Neither paragonite nor albite were observed in the rocks of the kgante sone suggesting both thet the sodiun content of thear rock is IOw and that it is contained in solld solution in musoovite rathor than bringing about aluthnet phase. Huscordte is kom to cury as wach at 30 percent paragonite in colld solution in association with paragonite In high-grade rock (20n, 1955, p. 49; Bugetar and Yoder, 1955, p. 225),

\section{Retrogrede netamorohtom.}

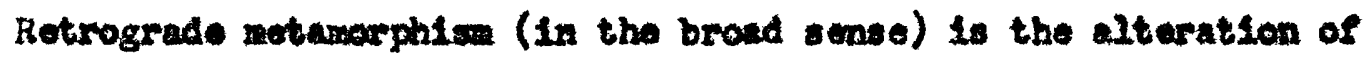

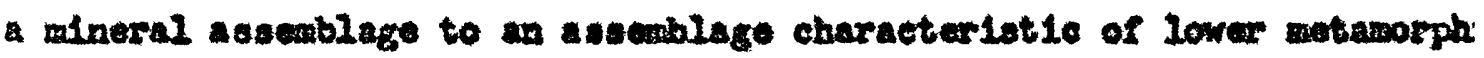
grade. It may be caused by cooling siontr wough to allow the winorals to partly change to an assobblage stable at lown motaworphle erade, by a later lower grade metanorphiom, by an inaroase in the partial vapor

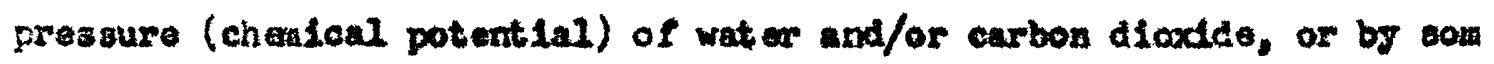
combleation of these factors. Hou (1955) has distingui atod betreen "monowotamorphle diaphthoresis," retrograde alteration in response to 
Pailing teaperature, and "polytertenorphic diaphthorests," retrograde alteration in response to either rising or falling temperaturo during a Lator poriod of motamorphisan. Hownver, ho did rot disous the poselidi1ty of retrograde atamorphiem in response to sudien inorease in the chealeal potent1al of volatile compenents, quite pos albly indopendent of temperature ehange.

Tho textures described previously wake it cloar thet in this area wineral assemblages of the kymatto wn heve beon alterod to assembiaget of the chlorite sone. Although ainor structurel features of two and pes baps three different orientations are ouporimposed, it is bellevod that these belong to one poriod of deformation. Both the high-grade arese and the retrograde feature are found along a belt of well-defined fold but these folde sea to be of the same age as tho Oreen Yountaln ant1clinorfuse. In the Lineoln rountaln quadrangle retrograde foatures are present in thd same belt, whereas kganit o-boaring rocke along the ereot of the Green Kountain antielinoriban mon to rotrograde foetwres. There

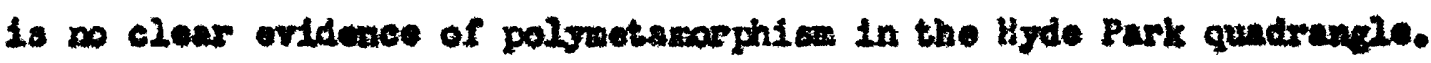

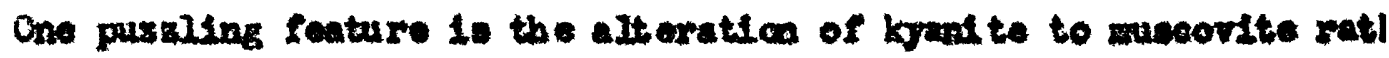
than pyrophyllite, wish would be axpocted if the altaration wore easer tially a hydration of kymite. Howeror, the six apedmons of altared kyanito, wh oh wore choeked by X-ray, contalned muscorite but no prrom phyilte. This night ouggeot that potassiun had been added from at external source during the retrogrede alteration. Howover, another alter. native would be to sasume that the assomblage kyanite-garnot-biotitemuecordtomuartz, as shown in F1gure 65, was present before the alterat: 
occtared. As rotad on page 83 there is sore puggestion in the relict

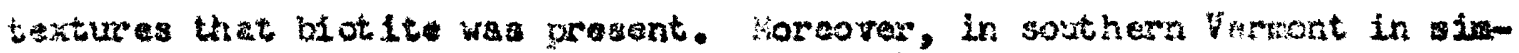

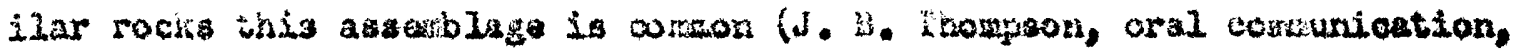
1955), and in the Honadrock quatranil of southern kew haspahise $x_{\text {. }}$. Billinga (1949. p. 1262) roporta a silimandte-garnet-biotitomascontte

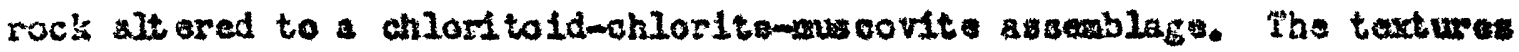
described are similar to those barved in the ligde Park quadrangle. If a kjante-gamat-blotlte-kuecovite-quarts rock having a congosition above chlorite on Flyure $6 f$ were hyirated, it is probably that the kyante would alt or to covite rather than pyrophyllite. Thus, It is felt that no addition of potacsive during the alteration neds to be poutulnted.

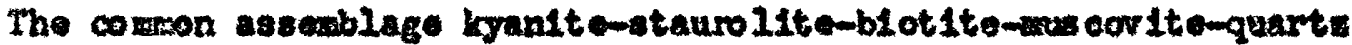
would also be affected in the seme mannar by hydration. Farller the poom sibility that this assoublage had bew present was diembsed becuse of the lack of any rellet textures ind le at ire of aturelite. Howrrer, the

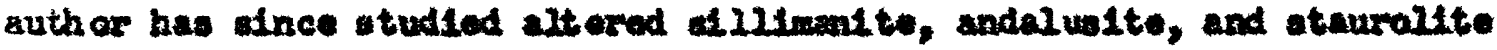
rocks In the Front hange of Celcredo and noted that it 1 vary disfloult to differentiste altered rullot textares of thoes the ninorals. How

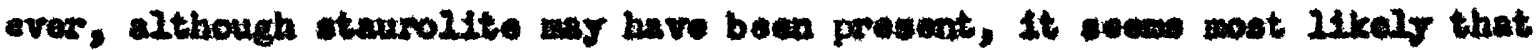

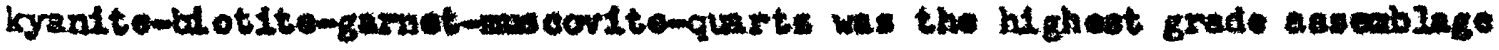
formed in this area.

All aueh retrograde ronetlom involre hytration of the higher grade asemblages. It sean inposible to deterwino the ther this hydration sccurred beome of coeling or because of an inorease in chenteal potan tial of watar, or sour comblnation thereof. 


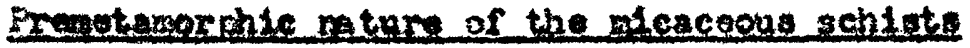

tunaral ataterant

.atikintary foatures wuch as bedoing and clastic gralns, and grose composttion indieate that the retimorphic rocks in the ligie Fark quadrancle, exeluding the greenstane and mphlbollte, were dert ved from joe-

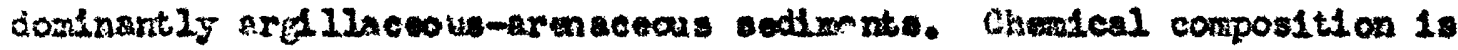
one of the fow posstble lines of arldence an to the exact mature of the "protolith" or parent rock whore the sedimentary fabric and mineralog has been alt ared. If the sotanorphio procesen in thio area did not inrolve important changes in chentical composition, then cheaical composiIIon should be as useful in determintag the aedimentary protolith as in distingulabing the different edimentary rocks roen each other.

Wo such etidy of the cherteal compostitan has been published and it whe mecessary to undertake a otudy of the chentenl compostion of argilLaceous and arenceotre sedimentary rodke.

The composttion of arglliaceous and erenscears sadinentary rock: Analyees of arglilaceous and arenceous rocks were oulled from the Lterature, rojocting all analyses which did not report all of the follo Ingt $\mathrm{SLO}_{2}, \mathrm{Al}_{2} \mathrm{O}_{3}, \mathrm{Fe}_{2} \mathrm{O}_{3}, \mathrm{FeO}, \mathrm{KgO}, \mathrm{CaO}, \mathrm{H}_{2} \mathrm{O}, \mathrm{X}, \mathrm{O}$, and $\mathrm{H}_{2} \mathrm{O}$, Analjoes $\mathrm{O}$ rocks from contact sones or whth any voln watalal woro also rejected. Finally all analyees ware rejeeted rut on could not be reascrably clasalfled frow the publiahsd desoription into the follonding groupst orthom quartiste or quartzose sandetons, aubgraynacke or noraal sandstone, gray wacke, arkose, and thale or elate. Cumblative frequency curves were then 
contructed for varlous oxides and oxlds-ratios to determine which wero most charactseletic of the various groups. The reults are surmarised in table 23.

Absolute values of wolght parcant are not too useful. Two rocks, whose detrital conotituante hre the composition, but hich contain ifferent amounts of calcite, doloulte, or Iron oxide centent would hare quite diffarent absolute welght percentagss and the lose relaticaship between the two rocks would be obseured. In addition tho gain or 108 of water, oarbon dloxile, and ot har constitunts durl re zetamorphim would affect the absolute valuse. Relative value of characteriot to conetituonts, oxpressed as ratiog, are wuch wore userul.

It was found that the reintive relues of $\mathrm{Al}_{2} \mathrm{O}_{3}, \mathrm{~K}_{2} \mathrm{O}$, and $\mathrm{Ka}_{2} \mathrm{O}$, and the absolute velght perent of $31 \mathrm{O}_{2}$ afford a rather good index to the sedimentary rook type. The rat $10 \mathrm{SLO}_{2} ! 31 \mathrm{O}_{2}+\mathrm{Al}_{2} \mathrm{O}_{3}$ would provide a bettar separation botwean enreal rock types, but it is wore diffleult to point out its relation to the rock clasalflestlond used by rarious sadinentary petrographers. Other Indlees ware lese vilublef for counple, the feOt

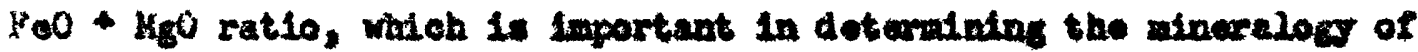
netamorphie rock is quite rapiable.

In order to aimpliry the comparison wth motamorphie roaks the andstcnes and representative thalo and slate analwes wore plottod on trlangular diagrane to shov eimultaneounly the relative values of the wole percent of $\mathrm{A}_{2} \mathrm{O}_{3}, \mathrm{~K}_{2} \mathrm{O}$, and $\mathrm{Ha}_{2} \mathrm{O}$. Thewe diagrans, ranked by the median values of the volght peroent of ailien, are sbown in Figure 7 in with wolght parcont of ellies is the axis of a tpiangular pelaw. Other 
Trble 13. Cheslenl oharacteristics of sedisentary rook types.

\begin{tabular}{|c|c|c|c|c|c|c|}
\hline & & $\begin{array}{l}\text { unrt zose } \\
\text { sandstone }\end{array}$ & Subpraywacko & $\begin{array}{c}\text { Groywok } \\
\text { (E) }\end{array}$ & $\begin{array}{l}\text { Arkose } \\
(4)\end{array}$ & $\begin{array}{c}\text { Shale-alate } \\
\text { (s) }\end{array}$ \\
\hline Sumber & I anslrses & 11 & 3 & 20 & 11 & \\
\hline 3102 & $\begin{array}{l}\text { Kn } \\
16 \\
2 \\
32 \\
3 x\end{array}$ & $\begin{array}{l}61.70 \\
91 \\
94 \\
98 \\
99.45\end{array}$ & $\begin{array}{l}74.43 \\
82.15\end{array}$ & $\begin{array}{l}52.34 \\
61 \\
64 \\
69 \\
72.62 \\
\end{array}$ & $\begin{array}{l}51.65 \\
63 \\
69 \\
76 \\
82.14\end{array}$ & $\begin{array}{l}18.56 \\
56 \\
59 \\
62 \\
84.14\end{array}$ \\
\hline $1_{2} \mathrm{O}_{3}$ & $\begin{array}{l}\text { ln } \\
12 \\
22 \\
30 \\
12 x\end{array}$ & $\begin{array}{l}3.0 \\
3.5 \\
6.92\end{array}$ & 12.76 & $\begin{array}{l}10.15 \\
12.5 \\
13.5 \\
15.0 \\
18.33\end{array}$ & $\begin{array}{l}2.55 \\
7.5 \\
10.5 \\
14.0 \\
15.50\end{array}$ & $\begin{array}{l}2.48 \\
14.5 \\
17.5 \\
19.0 \\
26.22\end{array}$ \\
\hline $\log$ & $\begin{array}{l}6 n \\
14 \\
24 \\
30 \\
4 x\end{array}$ & .00 & 1.63 & $\begin{array}{l}1.48 \\
2.2 \\
2.7 \\
3.4 \\
6.03\end{array}$ & $\begin{array}{c}.19 \\
.3 \\
.5 \\
2.3 \\
4.02\end{array}$ & $\begin{array}{c}.01 \\
.3 \\
.6 \\
2.4 \\
3.97\end{array}$ \\
\hline $2^{\circ}$ & $\begin{array}{l}k n \\
19 \\
24 \\
3 \\
4\end{array}$ & .00 & 1.09 & $\begin{array}{l}1.26 \\
2.5 \\
1.8 \\
2.1 \\
4.33\end{array}$ & $\begin{array}{l}1.28 \\
2.3 \\
3.1 \\
4.3 \\
6.16\end{array}$ & $\begin{array}{l}3 . \\
30\end{array}$ \\
\hline 60 & $\begin{array}{l}\mathrm{Ka} \\
19 \\
24 \\
34 \\
4\end{array}$ & 21,00 & .70 & $\begin{array}{c}.72 \\
2.85 \\
2.6 \\
4.0 \\
12.60\end{array}$ & $\begin{array}{c}.15 \\
2.85 \\
2.85 \\
77.0 \\
20.09\end{array}$ & 10. \\
\hline$\sqrt{80}$ & $\begin{array}{l}30 \\
10 \\
20 \\
3 \\
15\end{array}$ & 15 & 1.30 & $\begin{array}{l}1.22 \\
1.90 \\
2.25 \\
3.3 \\
4.06\end{array}$ & $\begin{array}{r}1.05 \\
.15 \\
.65 \\
2.95\end{array}$ & $\begin{array}{l}\frac{1}{2} \\
3 \\
6\end{array}$ \\
\hline$\sqrt{0_{2} 0_{3}}$ & $\begin{array}{l}74 \\
10 \\
24 \\
32 \\
1 x\end{array}$ & $\begin{array}{l}.05 \\
.14 \\
.45\end{array}$ & .55 & $\begin{array}{l}1.15 \\
1.50 \\
2.58\end{array}$ & $\begin{array}{l}0.61 \\
1.35 \\
3.3 \\
5.5 \\
7.95\end{array}$ & 36 \\
\hline 100 & $\begin{array}{l}14 \\
19 \\
26 \\
34 \\
x\end{array}$ & 1 & 3.08 & $\begin{array}{l}2.36 \\
3.5 \\
4.0 \\
4.8 \\
7.63\end{array}$ & $\begin{array}{c}0.31 \\
.4 \\
.7 \\
2.2 \\
3.39\end{array}$ & $\begin{array}{r}3.9 \\
6.0 \\
26.0\end{array}$ \\
\hline
\end{tabular}

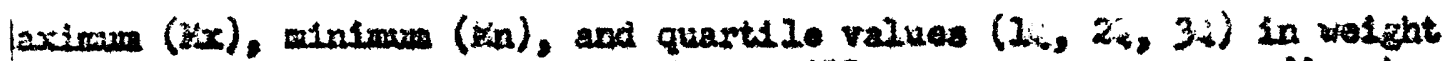

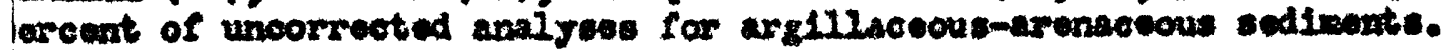
bte the following charwetertaties:

$\mathrm{AR}_{2} \mathrm{O}_{3}$ : $3 \mathrm{H}_{2} \mathrm{~A} \cong \mathrm{I}_{3}$

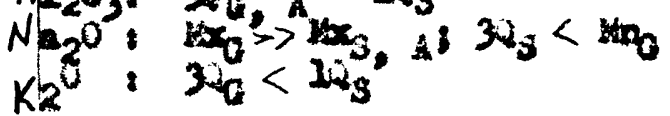

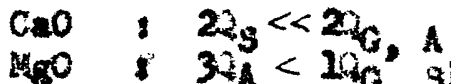

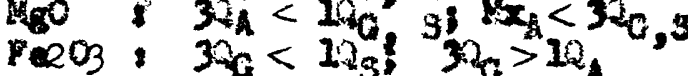




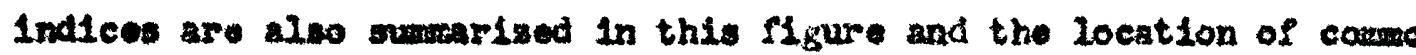
sedimontary and metanorphio minerali is Indicated. Cartain well-kno "ararage" or "compoalte" analyses of sedimentary rocks are also plot The quartiese sandstenes and subaraymackes are rather vell distInguished by thelr high $\mathrm{SHO}_{2}$ and $\mathrm{ION} 1 \mathrm{I}_{2} \mathrm{O}_{3}$-eontent. Arkose is dis. tingul shed by having the highegt alkall to luesina ratio, comronly af companied by a gh $\mathrm{K}_{2} 0$-eentent. The three points wich indleate $\mathrm{I}$ anall to alumin ratio suggest elther that part of the feldspar was calcie plagloolate or that the feldspar has bou extensirelf alteroi clay minerals. The grayudkes and the aheles are dituluguished from

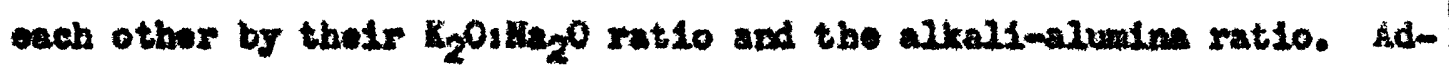
mittodly there is rather large overlap, but, consldering the 100 se elagelfleation of edimantary rooke and the poor descriptions sccore panying the analyos, the observed grouping secme senificant onough to be neerul.

It is inetruct 1ro to correlate the result with the winerelog of eodiandery rocks and with the observed atsblilty of varlous minerals durling weathering and sedibentatica. Different winerala vary preatiy in their otability during weathering, transportation, and disGenesis. OLIvine, pyroxtene, amphibolo, biotite, an celcic plagloelase aro relatively unstabls during oedicentary processes and to not apperer es important conetituents of sedi sentary rocks. Sodic plagloc.lase, orthoclase, woscov1to, clay minerals, and quarta are progressivat

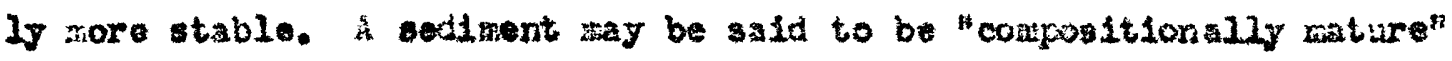
when it contains only the sost table ineris, an "taxturally moturst 
hen it is well worted, la oking wide renge of grain sises.

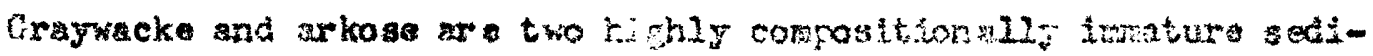

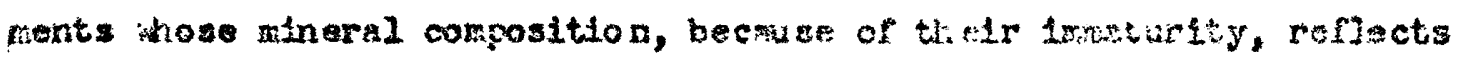
two contrastine source areas (Dapples and others, 2953, p. 297-302; folk, 1954, p. 353-354, Pott1john, 1954, o. 360-361). Graywacka con-

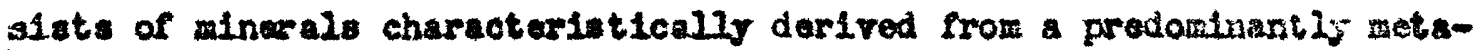
ropphie source area and is partieularly cherseterized by the preaence of rock fragments. Hrkose conests of minerals derived from a predonInantiv granitlo or gnelsbic source area and is particularly characterIsed by the prescace of potaselum feldspar. Soth of the se sodinonts are comonly toxturally imature, contalning wide range of grain atzes.

quartzose andintone, shale, and chemieal proelp1tates of dissolved pterial are both compositionally and texturally eature. Other sed1pentary rocks 210 betwean these fire end-membors. Inamuch as compos1Hicnel and textural maturity do wot meepearly accompany one anctber, borse sediments my be compesittonally mature, but texturally imature (10. a rook composed of quartz graine in watelx of finomgrained quart: und clay ainerals or quartsose sandston with a ealcite gatrix).

In sedimentary rooks sodtun is grinedpally found in plagloclase reldapar (Ha2O $=\mathrm{Al}_{2} \mathrm{O}_{3}$, wole pereant) and to a much sulallor extont in play winerals, espectally those of the montworillonite group (Kago< $\mathrm{Al}_{2} \mathrm{O}_{3}$, we parcent). Although actlum-bearing clay-minerals are known, the potagb-content of the elay minerale found in eedinontary rocks is much hLgher than the soda-centent and rost of the sodium in sedisentary 
rocks lo in slb1te. Whs, a seditentary rock with a relatively atgh soda-contant will elso have an sikali-aluratra ratio approuchine $1: 1$ indleative of the hlgh albite-content. On the other hand a sedinentery roek with a high potash-content way be indlontive of elther a high foldepar or high 1111 temoseovite content and the alkell-almina ratio may range wdaly.

Gartzose sard stones are corloualy characterised by their high ollICa content, wh1le shales are characterised by thedr low alkall-aluetra ratio and low sode-content, reflectirg the low feld apar and high elay content. The abundance of potash feldspar in arkoses is reflected in a highor alkalf-alumina ratio and in potawh belng wore cbundant than soda. It was noted carlier that grajuaces are charactaried chemically by thals high sodi content and by an alkali-2luming ratio lese than thet of arboses but hicher than that of shalen. Low-grade motomorphis rocke comeonly contain nearly pure albite, vareas Lencons rocto comonly contain wore calcio plegtoelase. Albito if laps apt to be broken down

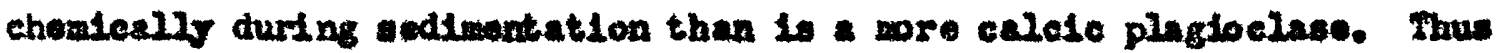

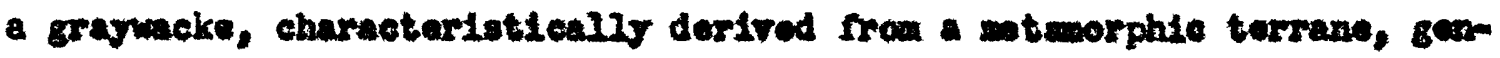
erally contalne more albitomand hence wore sodimbthen an arlose.

The effect of a carbconate or Iron coride cemont does not nask the above charactarlstios. 


\section{Explanation to Fisure 7 .}

28, 20, 3ire quartile ralues.

- Individural analyees

- compost te ar averoged analyzea

1. Compesito anilyat of 253 sandstone (Clarke, 1924, p. 547 ).

2. Conpostte analyole of 371 sandstanos ued for bullding staro (clarka, 1924, p. 547 ).

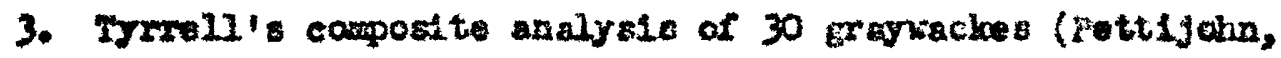
$1849, p \cdot 250)$

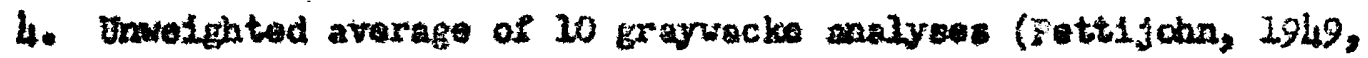
p. 250$)$

5. Unwe1ghtod averate of 33 Precabirian elates (Nent, 2951, p. $1466)$.

6. Composite enalyelo of 51 Paleosolo shales (Clarke, 1924, p. 552).

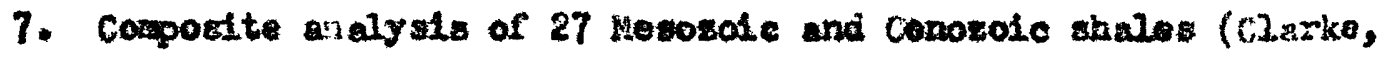
2924, p. 552).

8. Unvelghted average of 30 roofing slatos (Albee).

9. Unvelgited everage of 35 ceranic chales (Lanborn and otherg, 1939, p. 20).

Sapplonentary characteristics of shalos and elates;

C 10 roperted in wang ahalos, but in very ferix sandstones.

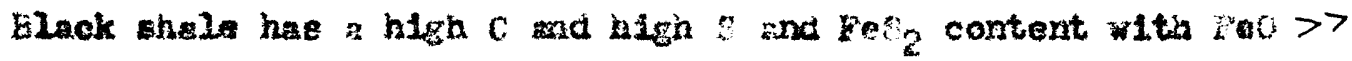
$\mathrm{Pe}_{2} \mathrm{O}_{3} \mathrm{it.j}$

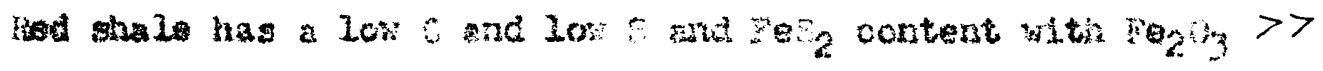
Feo (r.t. 


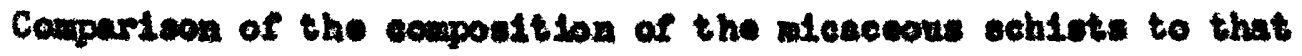
of gedizentary rocks

The compartaon of the chandeal conposition of the nicucoous schlots ifth the cherical composition of argllaceous and aronaceous sedineatary rocks is compliceted by the $10 \mathrm{~s}$ (or gain) of eartein conotituents durlng netanorphias. Tho wost important of these are vater and carbon dioxide. The sogrogation of quarta into lonees and voins may leare a rook $20 s$ rich in ilica. This prosess is quite troublescre, inasruch the the allics-eontant is ane of the wost ueeful indices to the typ of sedinentary rock, and can probably be overcome only by an eatimate of the amount of guarto In lensen and reins in ach indiridus 1 outerop.

These two effects an be shown by a plot of $\mathrm{Al}_{2} \mathrm{O}_{3}$ (wetght percent) agalnot the wolght pareent of all othor conutitucate except allies, (100$\left(310_{2}\right)$. The wolgt poreent of alumina and allea wre ealeulated graph-

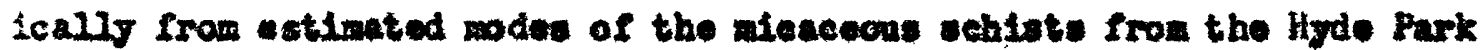
quadrangle. The great variation in the conpositica of those sebiets made

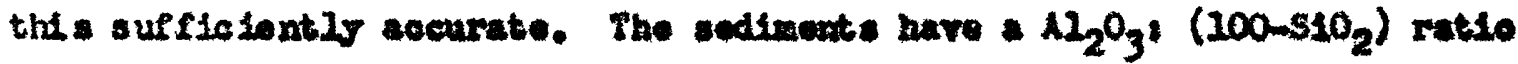
With a modisn of about .45, most ranghe botwoen .35 and .55 . Those points with a ratio lese then .35 were found to oontaln rathow lerge quantitios of carbonate, iron axtde, or grephite and pyrite. The sobite have higher ratio, ranglas aroum .55. This 1 ollghtly exaggerated as no stimate could be wade of uncombined wetar in the wehist. The lows

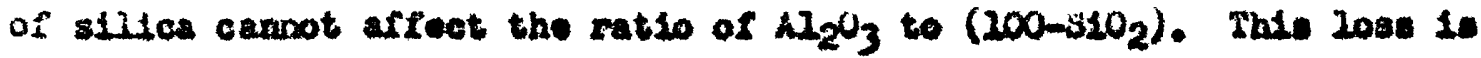

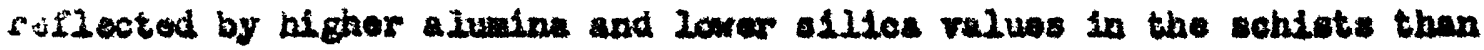
are found la any sedimat. The shift toward higher aluedne and lower 


\section{allea ralues is elear in P1gure 8.}

Comparison of alliea-conteat, and of any othor abeolnte ralues, wat

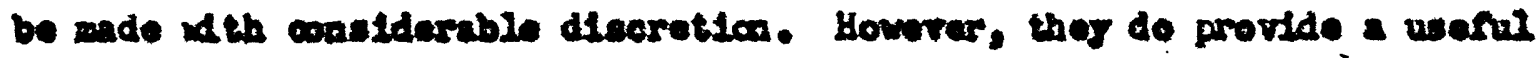
qualitative galde. The parecntege of albite in a scok (ascuming all the codtur is in albito) is allghtly grouter than ten times the wolght par-

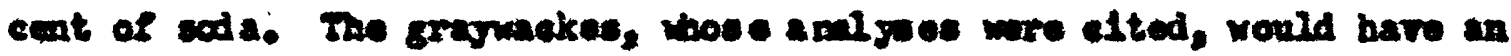
albite content ranging from 15 to 60 pareant with andin at about 27

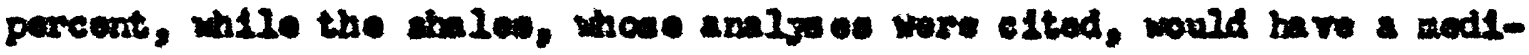
an albite content of about 6 pereont and a andmin of about 40 paccent. The third quartile value for halo is only about 15 poreent, which is

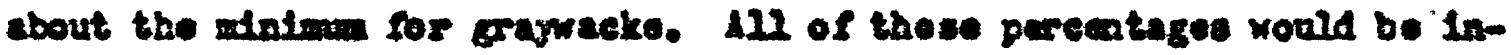
creased in a motamorphis rock dwe to lowe of volatiles and silles.

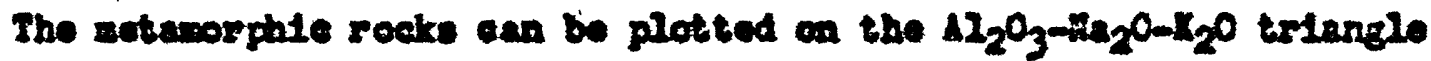

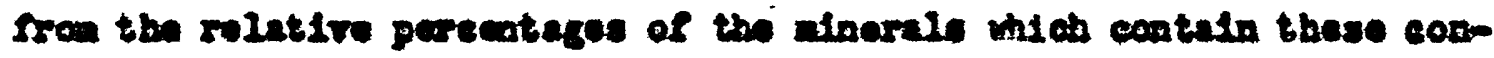
atituonte. Intiated sodes frow varlou formations in the Hgde Park

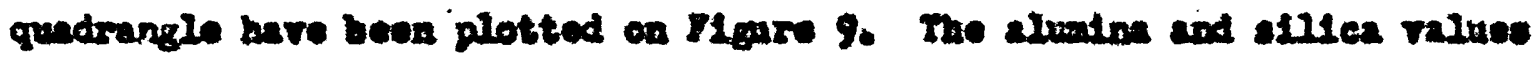

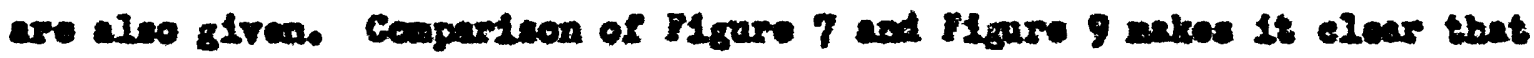

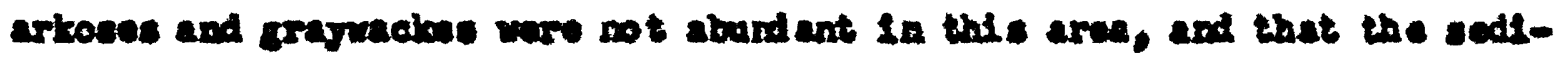

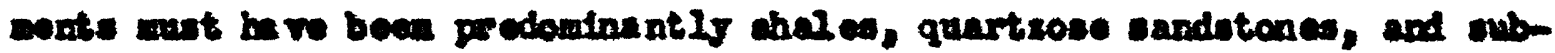

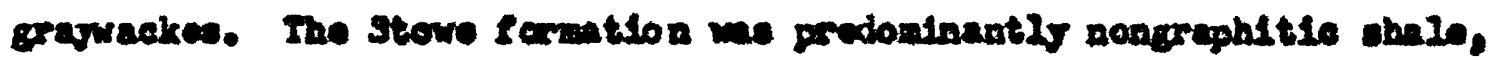
the Ottenquechee farmation was ade up of interbodded quartsite and bieck chale, wile the sedineste of the Camels Hump conp wore more rapled.

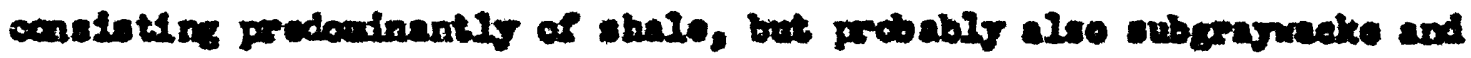
sowe quartsose sandstone and graynecke. One thin section from the Vorotorn formation mageate as aribose composition. 


\section{WBOIONAI RELATIOAS \\ General atatoment}

The Grean Hountaln antlelinorlu is the for structural foature of Vormont, extending north-northeast fros the wasachusetts border the full length of Varacht and about 50 nllea linto luebec, a total dietance of about 210 miles.

In the souihorn part of Vermant Ercesmbrian rocks are exposed in the cere of the antelinoriwn. SIfghtly netanor phosed rocks of Lower Cambrian to Midlo Ondorialan (with the posatble exception of the Hidd1. Cambrian) age, the Westarn Vernont sequenee, reat with pronounced angular unconformity upon the west elde of the Precambrian core. To the and the Frecambrian cere is orerlatn, again with pronownoed uneonform-

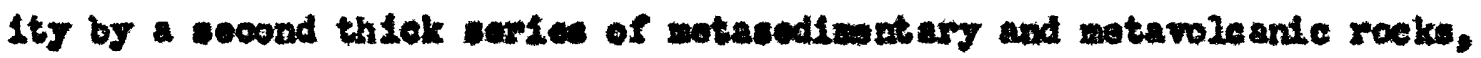
the fectorn Verwoat ecquenee. The upgor part of the eastern sequence 1s aparaely fosellifowie, inaluding rooks of Middle Ondorlolan or

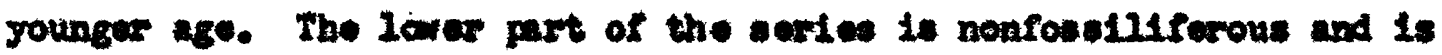
belleved to inelude Cambein and early Ordoviolan rooks. A third acti-

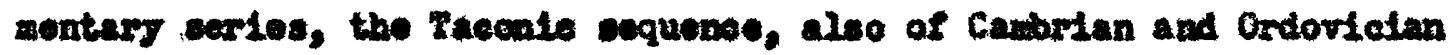
age, reats with atructural diseondanee upen Ondorlatan roeke of the Weatera Varmont sequance.

Although preaumably equivilent in age the coupocition and degree of motanorphion is rory differant in the three sequences. Ine bastern

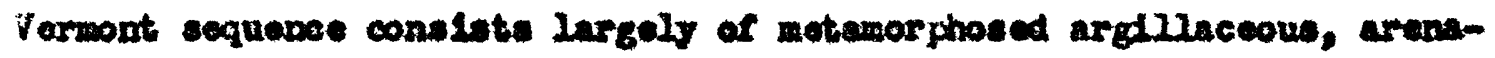

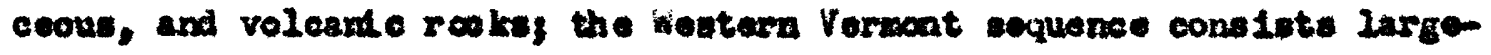

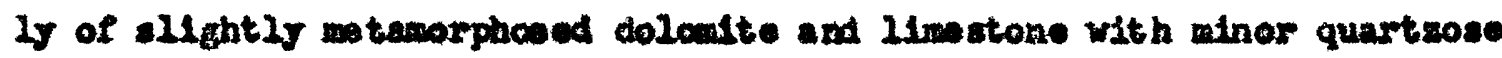




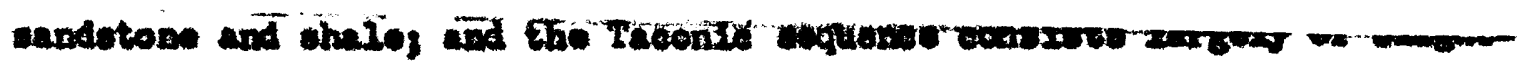

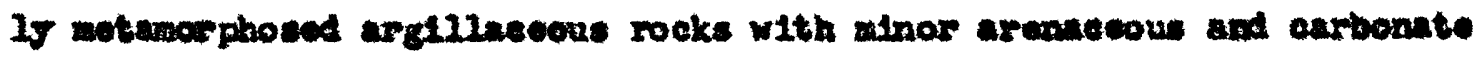
rocks.

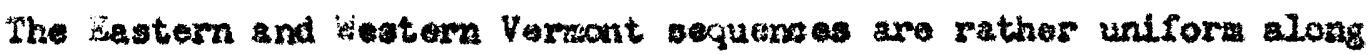
the atrike and Individual formations can be traced frow the tisesechusetts borter the full leagth of Verwont and sowe distance Into Canada. The major probloms confronting geologists working in Varwont are the correlation of these tree sequeneas and the relation of the Bactern Vermont esquence to the Hew Hauphinire eoquence. Rapld esut-wost facios changes, extensive uneonformatt les, and thrust falts of unknom extent have all been utillized in the ccerelation of thess acquenees (Oaberg; 1952, p. 68; E1llings and athers, 1952, p. 10; Braco, 1953, p. 54-57; BLllings, 1956, p. 89-99). Howovor, at the present t1me thare is no generally accepted corralution.

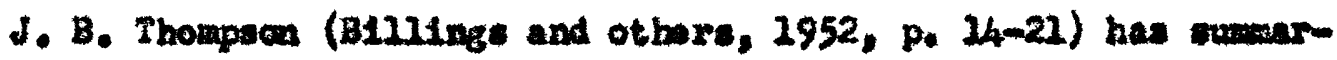
1rod the g0010gr of ocuthorn Verment (south of $44^{\circ}$ north latitude) and hat discused those major problems. Wo simllar ownary and map are avallable for notharn Verwont. The ecology of north-eantiral Verwont,

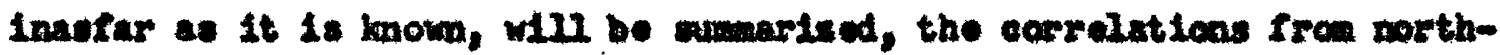
central Vormont north Into Qubbee and cuth to couthern Vermant adll be Indleated, and the many problewe which atill rowaln unsolrod will be pointed out.

Nuch of what is knoven of the goology of north-eentral Verwont is a result of the work of W. M. Gady, the author, and A. H. Chldester, all of the Untted States Geological survay; publt shod sources are in- 
dieated on Plate 4. The Western Vermont equence in rorthern Verront rather wall known due to the work of Cact (1945), Booth (1950), 3haw (1949), stane (1951), and mumerous esrller vorkers. Areas in sueber. jut north of the International Bcundary, have been mapped by Clerk (1934, 1936), Amorose $(1942,1943)$, and Cooke $(1950,1954)$. Untortunately, the wark In quebee wa not detalled and the interpretations and otratigraphic numes very widaly. Several of the formation boundaries

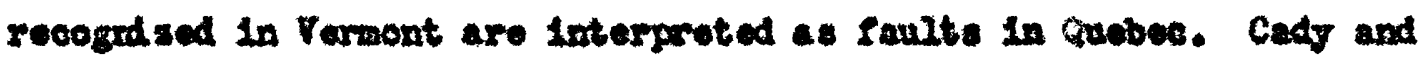
the author have risited Cooke and clark in the tiold aoveral times and

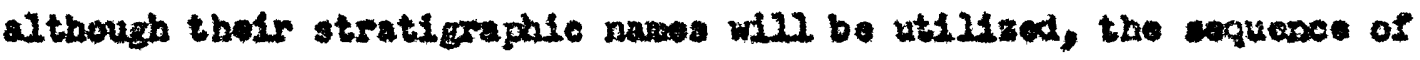
formatlons is revised to it the writer's carralation with the forsont sequence.

\section{Strat laraphy of Horthern Vermont}

The Precasbrian cere of the Green Hantaln anticlinorlun plunges warth under the Paleesole shists in the eren couthest of liarren and Brecabrian rocke do not appear anyiner to the north along the axis.

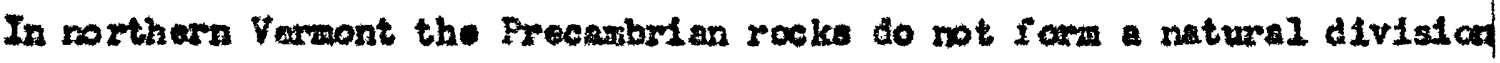
botweon the eastem and woatern sequences. The Wostern Vermont seguence In northern Vernont can, for conventence, be defined a tho el rocks above but excluding the lowest fosalif rous rooks-the Cheshire quartz1te and Its equivalente. A otfip, hich 1108 just wost of the main chain of the Green Nountains, is not included in ather sequence. It Includes the basal Crebrian ( $6 \mathrm{~b}$ on Plato 4 ), the Tlbbot H111 schist (cbt), the "Jay poak series" (JEs), sxid the precambrinn rocks (it) west

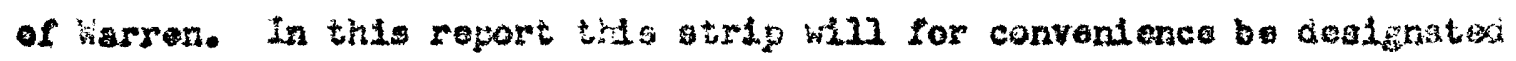


a) the Hortb-eentral Varmont equence. The Caste flump group and the rocke east to the eastern 1 indt of the Q11. Wountain foration may bo dofined the bastark Vormont equence in northern Vormont.

\section{Eatern Yermont nequenge in northern Jemont}

Tho gradual developount of the standard section and the north-Bouth Corralation of the Santern Vermont seruence in northern Vermont is oum-

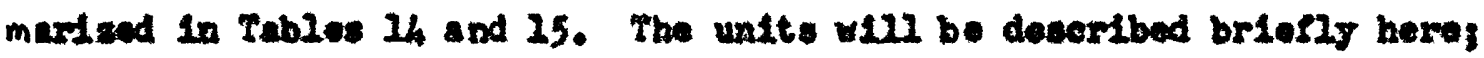
many of thea are present in the Hyde Park quadrangle and have beon desarked in detali.

Hiohardson (1902, 1906, 1919a, 19196, 1924, 1927), Porry (1927, 1929), Currter and Jamn (1941), and Doll (1945) recegniged and nomod

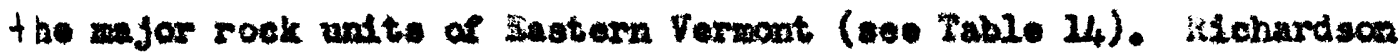
traed an uncenforaity, now recognised as the bese of the Shav jountain formation, the wole length of Yarment. Thts eorresponds to the bace of the highor "clay slate" of Hitehoock (1861). The Shaw Hountaln formition Currter and Jahne, 1942, p. 2496-2499, thitte and Jahne, 2950, p. 286) crnststs of quarta conglomerate, soriclte ochlet, and linestone. The formation is thin and 1s absent at sose points. The Shaw Hountain formotion can probably be carrelated with the Pensely Pond conglowerate and the uppormost part of the Sherbrooke group in wubee. Throughout this Latunce the Shar Mountaln formation aparates the nonealeareous rocke in the west from the calcareous rocks to the ast and forms an axtrualy important refarence point in the rorth-south corralation of the satsrr

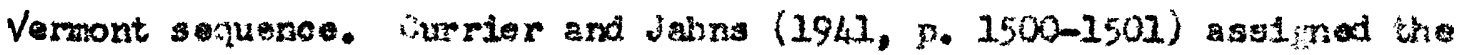


Shax Mountain formation to Midd2 Ordorletan or youngor on the buelo of the a1se of crinold colwals. B111ing (1948, 1956, p. 92) and poucot and othere (1953) have aggeated that the Shaw Hountaln formation 19 of lowernost sliurlen age.

The rooke overiylng the Shaw Kountein formation consist of interbedded Impare linstone, gray to black phyllite or slate, and quartsite. In hi gher metamorphle grados the phrllite bocoave a chlot containing

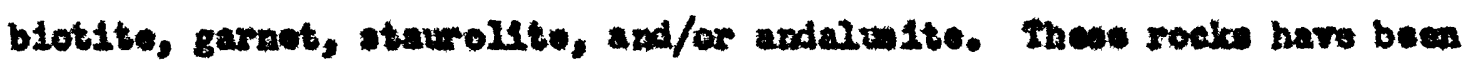
abdirsded on the basts of the rolative anount of the various roek typos.

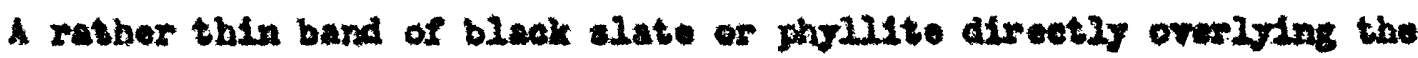
Shaw Wountain foration ba been oulled the Northileld formation. The

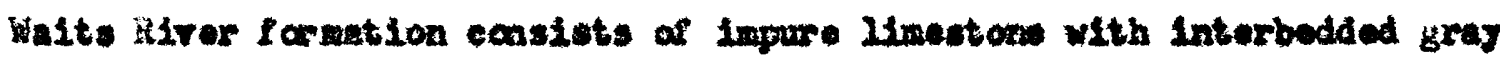
to black phyllite mile the 011, yountaln formation censiots of aray to biack phyllite and mieaceous quartalte with thin bed of 1 ingtone. In

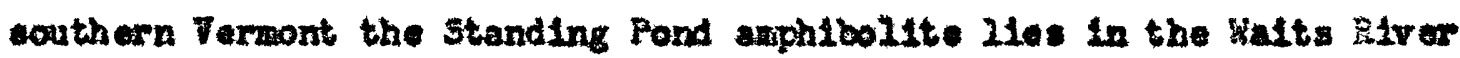
formation near the cantect wh the Glle yountsin, but this unit has not Jot been traced through northern Verwont and does not sean to be continwous. The rocks above the Bhav Mountain iormation corralate with the St. Franeis group (Cooke, 1950) and possibly with the upper part of the Clenbrooke sroup (Clark, 1934, Ambrose, 1942, 2943) in Jubbec.

The socks botween the Shaw Nountaln formation and the Frecambrian rocks are predominant Iy argillaceous, aranaceous, and roleante rocks with very fow darbonte rockt. The Cran Hill foration (Currter and

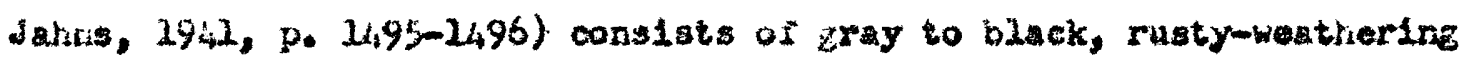

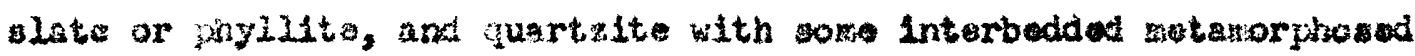


roleanias. The horetowa formation (Cady, 1956) conalote of a graj-grea

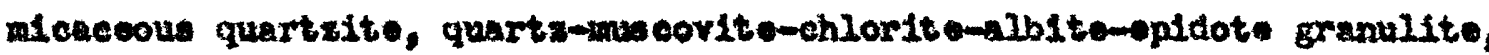
and greenstone. Forphyroblasts of blatite and garnet have been noted if areas of hil char Eatamorphic grade.

In eouthern and eentral Verwont the Cran ULL formation cewe to

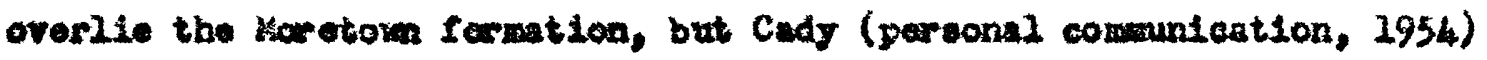
Indicates that in nopthern Vermant the two topes of rook are nerely Intorfingering sodinontary freles and do not waintuln a definite atratigraphie postion. The Graw KIII (and Loretom) somation, as suggedted earlier by Currtox and Jahns (1941, p. 2496, p. 1508-1509), vewn to be the equivalent of the Beaucer1110 (Kagog) elate in ouebec, which contain grapto Lites of Wormanakill age (C2arke, 1934; Ambrose, 1942, 1943).

East of Hansomille, jubbe and extending wouward Into the United States are 2arge areas of releand e rock (Bolton group of Cooke, 1950) whth have been rariouely wapped te interbedded rolcanlo rocks, intruIve rocks, and as post-ietamorphic voleantes resting unconforiably on 211 the other rooks. Cady (personal communication, 1954) indlcates thet ach volcante rocks are Intarbedded with the Cran bill and Moratown forwatlong just west of Lake Monphrekagog. Therefore, those rocks have beal included with the Cran HII and horotown formatione on plate 4.

shoughout wost of the state there appear 3 to bo a gradational contact botween the stove formation and the hor town formaton. however, In northern Vermont, onat of Lowell, these rock units are separated by the Unorolle bill conglowersto for distance of about 26 miles. hie

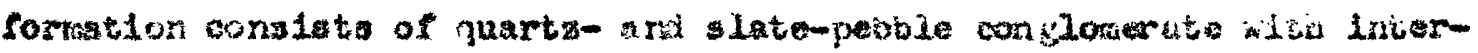


beds of curleste slate and greenstone. Forphyroblate of ehloritold are sburdant in both the conglonerste and the site. the foretion thins to extinction to the south axd to the rorth gives way to spenstonos mapped as the upper part of the Stowe farmitod. In the hyde Fark quadranglo a probatle angular uriconforalty bas been noted, but this ralation ba not bean seen elewher.

The stowe formation (Cady, 1956) repluces the "Betbal schist" of Perry (2929) as the formor nam wa proccuptod. Inlo formtion bas

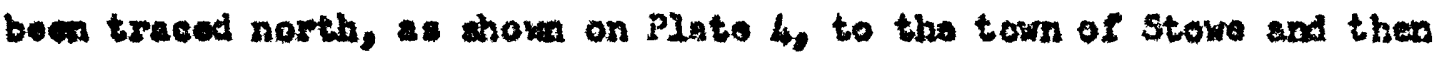
north into the Lowell ares. The stowe formation condsts of ilverm green, quartemsericite-chlorite sohjat sn phyllite, and grematones, wth some interbedded blek phyilto in the uppor and lowar parts. In highor entamarphlo grades the schlsts ontaln chloritold, garnot, and kyanite, and the greenstones are metaxorphosed to opldete amphibolitea.

The Ottaugueche formtion (Forrs, 1929, p. 27) has boen traced in a narrow band north from woth of fiarran to the Hyde Park gnadrengle.

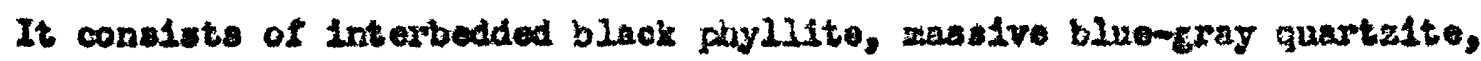
and quartr-soricltemellorite phyllito. Hear idin the Ottauquecheo formatica is covered by an axtensive area of gloclal daposits. Its eculvalont north of tids covered area corajats of Interbected bisck phyz21te, pobbly quartxite, asd pebbly quertz-ouricte-ehlorito phyllite. The cttauqueche foriatics, wish north of Lowell 13 in part probably equivalont to the stowe farmation, has been traoed north to the type locality of the hansonville slato (ayoros, 1942) at Wansorvinge, we-

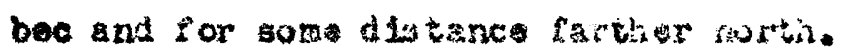


In couthera Porment the Ottauqueches formation is underialn by the Plnney Hollow formation (Perry, 1929, p. 26). This foration is lithologleally a indiar to the Stowe formationj ellvor-groen quartz-serieltechlorite chist of phyllite with cow zrenston and black phylitte. In part of couthorn Verwont an amphibolite, the Choster amphibollte, 31 as at the top of the Minney Hollow formation. The Planey Hollow for he bow traced northward into the vidnity of Karren (with consider-

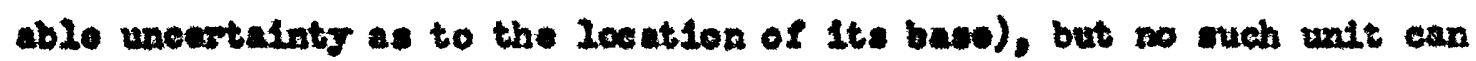
be distingulabed underlying the Ottauqueshe formtion for some distance now th of the Winoould Miver. Hear Harrieville a narrow bund of quarte-

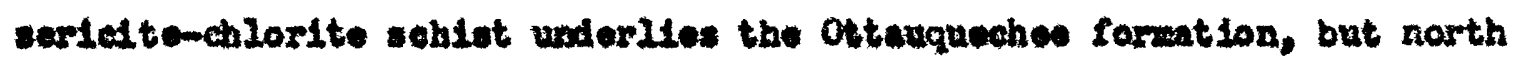
of the extemelve area of cover the Belvidare Kountain amphibolite underLles the Ottaugueche formaten. The Belvid are Heuntaln amphibolite hav been traced morthward inte pubbee, and may poesibly be an equivalent of the Chester amphibolite.

In southern Vermont the Hoose formation (Thompson, in B1111nes and others, 1952) underl1ea the Plnney Hollow formatlea. The Hoosac formation conalets of gray or black echl at with abundant porphyroblasts of albite, and contains quartzmsericite-chlorite ochl at, quarte1te, dolareite, greonetone, am wlerocline augen gneies in varlous areas. the underiyind Tyoon formation consists of conglowernte, schlet, and "grayrscke."

the Precanbrian plunges und ar this sequence weat of Warren and the Plnney Hollow, hoosec, and Tgeon farations have not been diatingulshed In northern Vermont. The canels Hump zroup (Cady, 1956) has been defined to Iriclude those rocke beswen the base of the cttauxuechese foring- 
tion and the Frecambrian. The Camels Husp group conolst predoninantis of a motonous sequence of interbedded graphitic and non-graphitic, quartz-serlett o-chlorito schlot and gneiss with porphyroblastic albite and some thin quartrite. In a fw areas it contains gernet and blot 1 to.

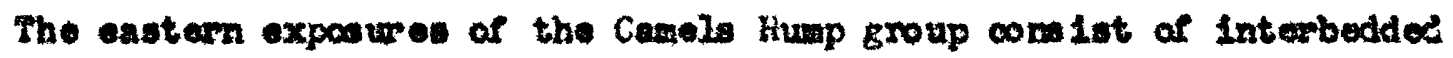
graphit ic ochiet, wlescoove quartzite, nongraphitic wehi ot, and wasive quartzite. In cortein aroas it is difficult to distinguish the latter 11thologte ansemblage frew the orerlyling Ottauquecheo formation. Dow tailed petrographle work indiontes that there is no olgnificant compositlonal difforenee between the two apparently disalmiar Itthologle assesblages of the camels thump group, and Indicates that the difference is prodominently textural. Hear Bden the Belvidere Hountatn apphibollte is directly underlatin by the course-grained porphyroblastlo albite schist and gneiss. The Sutton achist along the axis of the Creen Kountain (3utton Yountain) anticlinorlum in quobec consists prodominantly of albite schlst and Enolss $f \times$ distance north of the Internaticnal Boundary. No rellable maping unit have boen found in the camela liump group in the northern part of the state, alt hough bands of s1lver-green quartz-sericite-chloritomagnetit schos to bavo been mapped for linited dis tances in the Hyde Park area.

Wear Lake Heaphreagog in zuebe, the Beaucevillo slat es are overlaln unconformbly by two syncilnal tronghs of fossilfferous slates (the Glenbrooke eroup) of 31lurian and Dovoritan age (Clask, 1934; Ambrozo, 1942). Cady (written corarunieation, 1955) indicates that lithologic six1larities strongly sugest thet thess rocks aro the ouivizont of the 
Shew Nountalla and eueseoding rocks in Voxmont.

Western Verrsont eequence in northern Vermont

Oeologic wark in the isetern fermont sequono has been in progress

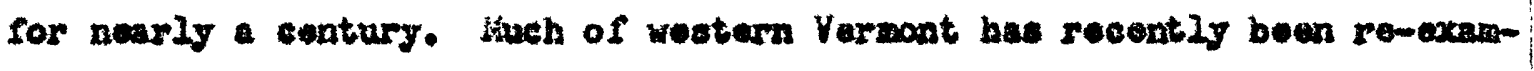
Ined in Ereater detall by Cady (1945), fowler (1950), Shaw (1949), 3tone (1951), Flower, idodgere, thompeon (81114ngs and otbers, 1952), 2en (1955), and Laciadjen (1956).

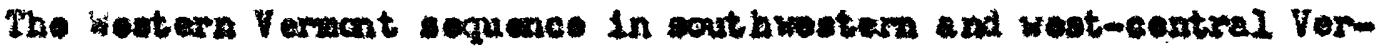
mont ranges in age from lowent Cambrian to Hiddle Ordorielan. The Iower units are predominantly of dotrital origln, lacluding quataite, phyl14te, graymake, and conglawerate, with dolomite in the upper part of the loxer Cambelan. The central and largest portic of the sequence consists largely of carborate roclos with dolomitle limotones dominant In the alder farmations and calo1tic limatores dominant in the younger. Slates and phyllites of klddle Ordoviclan age reat unownformably upon the carbonate rocks and loeally truneate the Paleosele rocks so that they rest upon the Precambian basanent.

The corralation of the Westarn Varmant eoquence from Hassachusetts and New Yorik north Into wubec Io rather woll ectablished and is swomarised in Table 16. Several of the units whila clark (1934, 1936) and Bpoth (1950) placed in the Lower Cambian hare ben shoin as Mtddie or Upper Cambrian to correspond with Shaw' (2949, 1954) work. Many of tho units grade laterally sorthwara into unit of dirferent lithology (what, 1949; itcas, 2951); saveral carbonate units gaining slato nembers or 
beling roplaced complotely by alate. Ito wolo sequence eppears to thickan northuard.

The Dunham dolonite and Cheahiro (G1lman) quartaite, containing fos11. of lower Cambrian age, are the lowest fosallifmrous units wilch have been traed the length of the state. Indeed, the type locality of the Dunhan doloutte is in Jubbe and that of the Chothiro quartaite is in Kassachusetts.

\section{North-oentral Vermont sequenes}

In weat-eentural Vermont the Menton formation consiats from botton to top of the Mickracket mobor (grayracke, quartaite, and conglomerate),

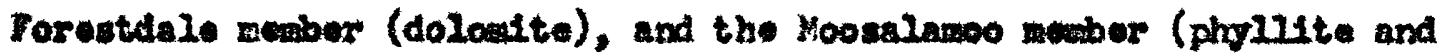
quartsite) (Oobers, 1952, p. 26-36, Brace, 1953, p. 30-34). The N1eica-

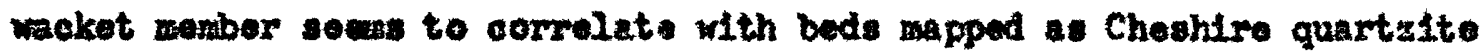
now North Adars, Kassachus etts wieb contain 01encl7us (Osberg, I952, p. 35; Brace, 1953, p. 33). The K1ekaracket, Forestda10, and Koosalanoo members (Kendon "eoriean) corrata with the Plnnacle graywacke, Whto Brook dolonite, and weat sutton sinte respectively of Clark's (1934) 0ak H111 series and of Booth (1950).

In northarn Vermont and north into subbe the PInnacle formation is bellered by acte to be underlain by a grenstone unit, the ribbit Hill echiot. Clark (1934, p. 10, 1936) and Booth (1950, p. 2155) believe that the Pibbit HII schist is the oldest undt exposed, but that 1t is of Faleoro1c age. Keconnalssance by Cady and the author suggosts the pose1b11Ity that the Tlbbit Hill 3 chlat lios yithin ratior than under rocks of typled rinnaclo ithologe. 
Booth (1950) has attengted to distinguish these lownrost Cambriss Cormetlone In the area between the International Boundary and the Winoon sid hiver. The rest Sutton formation and the planaele forestion approas Lthologio aivilarity in this area, conalsting of andy slate or phollit graynack, and conglomemates morcover they merge and are Indistinguithal ware the White Brook is absent. "This thinning of the (knsto Brook) dd onite veatwand and wouthund oreates a froblem bosause it is an oxceller borleon warker; without it the soparation of the west Sutton and pinnacl 1s Inposalble in man pluce" (Booth, 1950, p. 2147). The eastern IImit of Booth's mpping was there "the Pinomele terreno ceads to pass Inpercoptibly eastwand into the more attaworghosed roeks that 1 lank the Grem Mountains" (Booth, 1950, p. 115i).

The author' and Cady's recomnalswance lmiloate that booth's doterif tion 1s quite appropriate. The athor has mppod the vestern contact of the albite schict of tho Canels Huwp group north of the Lamollie ritror. Between that contact and the eest ern edgo of Eooth's mping (PIsto 4 ) the ajor rock type is a flne-grained quarts-sexledtemchlorite schl st or phyllite wth abundant highly-ehlor1t10 "graynake", greenstone, nnd ing black phyllits and quartatte. The "graymack" is abundent oely in the wostem part of the area. On Plate 4 the areas in which "graynocke" is abrandant have been designated as basal Cambrian ( 60 on Plate 4 ); the achistose areas to the cust heve been deolgnated the "Jay foak series" (JPs on Plate 4), the term belng used without any stratigraptic elgnif1cance. Tho line batween way represent the contact botweer the sot ton and rinselo fermations, but is at best merely an spproxtrention. 
Horthwest of Jeffersenville is an aran, as ret undeklned, of biek phyl11te, black limstone, and blick quartalte (JPSb on P1ate 4) which appears to bo in a syoline surrounded by the quarte-soricito chlorito sohlet. Farther northweet of Jefforaomille wavatve Highly chloritic "Eragwacke" and gxoenstone are common and are diffieult to detinguish frow on another. It is likely that the is an antialina of libbit hill greanstone. South of the Lanolile River the "graymek" is coarsar gralned and wach 1 we chloritie.

Frimary arld ence for to po of bedemend in places oren for beddingIs not abundant and dotaliad mpping is required in this aroa. Howror, a tontative pleture is that this wo le aren conselets of the Heat sutton and PInnacio formatione with broad antioline and a broad arnoline nor threst of Jeffersonvile.

\section{Igneoue rodks}

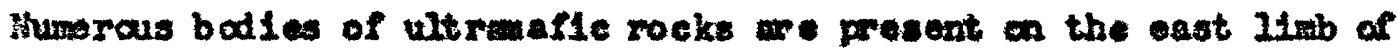
the Green Kountaln anticlinoriun, aly the largest of wich can be show on the map a for are also known juet west of the Green Hountain axis. Gevaral of the bodies contuin dunite cores, but cost have been axtenaiviif or conpletuly altered to sorpentinite, talc-oarbonto roek, and steatite. These have boon assijned an Ordoviolna age inasmeh as such rocks are not known to intrude strats younger than Ordorlesen in wostern Hew Ingland or adjacent subes.

post of the egranitle rooks in the esatern part of the

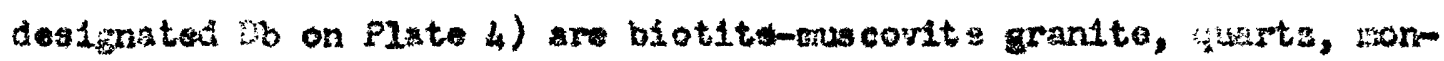

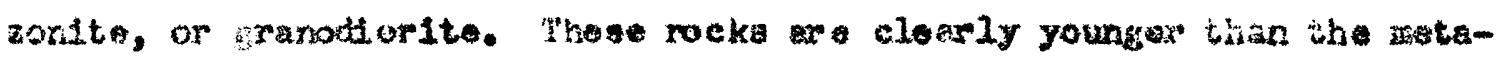


sedimentary rooks and apparentily 1nto-teotonic. They are almilar to the grantite rocks of the Now Hamphire sagaries (B1111nga, 1934 ).

9ereral alkallo atocks (deolgnated kin on Flate 4) are clanrly younger than both the deformation and the reglonal netamorphisin. These are largely syculte and granite and are sladiar to the rooks of the hitite

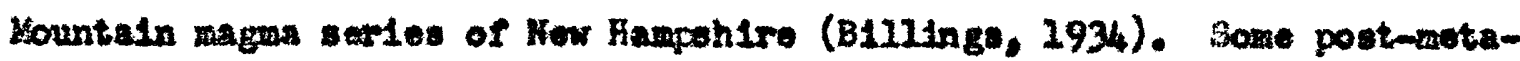
worph10, Ano-gradiod lawprophyre dikos are provent, but are too mall to be shom on the mp.

\section{Structare}

It Is evident frow the proceding discusson that the Groen tount in

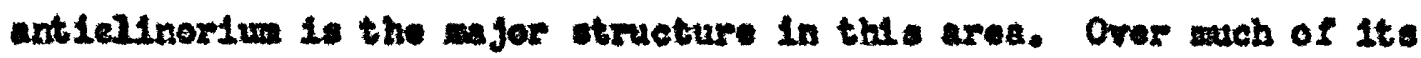
langth the antlelinoriws is a broad atrueture wth sereral important exes, Inereasing the diffenti of of correlation acrose the antielinoriun. The loeation of the axis is not knowe in dotall in the aren junt north and south of the sinooski ilver. The ohing quarts-aordetto, chiow rite schiots of the "Jej Peak ories" arose the axls in an axilal depreaalon noar Hontgomery Cextor. Structural relstians the southern edge of this axial depresulon suggests the presenco of a 20021 thrust fault, and the agneifine, containing rokk of the "Jay Peak cerles" osat of the anticlinorial axis aoens to be overturned to the wost. Thia aymeline, the Foot \$rook syncilno, contaline rocks tentetively Identifled as the Stauquechee and Stowe foration In the Hgde Park quadrangle. The rocks of the "Jay Peak series" apprently thin to extinction in the southern part of the foot mook synaline.

West of lowell a enerally ast-yest trending and vartickily alpping 


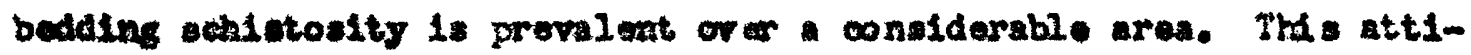
tude 18 wall expoesd at tiacens Notch in cllf fo or ar 300 feet in helpht, but the weture of the enjor structure la not jot knowe.

A general antlolinel zone mot bo prosent in the betweon the Poot Mrook aracline and the main band of the Ctteuguechoo formation, but the axd has not been aceurately located. A group of large folde great2y broaden the outorop brandth of the stowe fermation is wach of roortharn Varmont. Hortheant of Larell the stowe farmation arops out in a large narth-plunging anticline.

The folds In the Hydo Paxk quedrangle aro dmonstrated by the coor pleadty of the Ottauquacheo-stowe contact. Tho larce ultramefio body

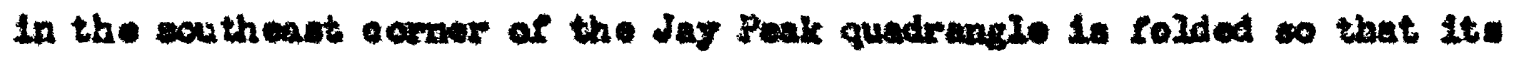
exposed Wdth 1s mob groater than 1to acturel thicknose.

The great variation in the width of the Cran H12l-Horetown formatlons northweat of Hardudok is so jot unoxplatned. It is probsbly duo prined pally to tho dying art of folds, but etratigraphie convergence and the dlsconfornity at the base of the oreriging shar kountain forrattion ay partially reaponstb le. The struoture above the shan kountain formation in northorn Vermont is as yet pooris lmown. The dile

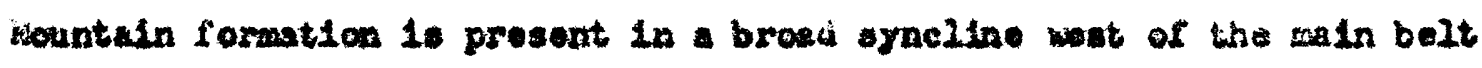
of 1te expomare (Dennis, 1956, p. 35-39).

In 4 rebec the base of the hanwonvilie formation and the top of the Sherbrooke group (Shaw Wountain formation in part) aro intargreted as faults. In the opinion of the suthor no of othars this is defindtely

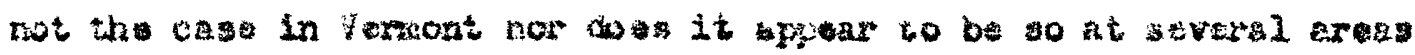


valted in inebor.

west of the axis of the Creen Hountain anticlinorium the amo general picture of brad shallow, but hikhly plteated, folds appear. 10connalssance westward from the axis of the oreen Nountain anticlinoriun in the liyde cark cuadrenglo to the 11 aroa of black phyllito, black Iimestane, and black quartait (JPSb) nor thwat of Jofforaonville Indtceter that the beds grow auccessiraly younger from the exis westwand. Farther weot it is ball erad that the roeks are mecessivaly older for about two Ilew wet to the area of groenstone. Booth (1950, p. 2154) indicates thet thi groenitone is part of the ribb1t HIII greenstone exposed in an anticline. The rocks west of this greenstone hare been groupad with the West 3utton and Plnnave formations by Dooth (1950).

Both Booth (1950, p. 1155) and clark (1934, p. 10-11) concluded

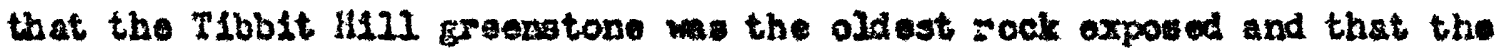

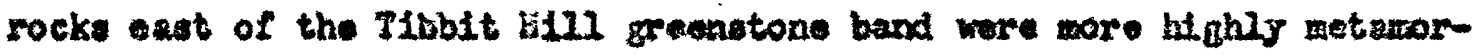
phosed and I1nor Eritned equivalonts of the Cak lill sarles. Clark Interpoted the oatern border of the Tlbbit Hill groenotone as a fault (tho Irowe thruat), but Booth (1950, p. 1155) sayo "... the Tibbit iill -Green Hountain rocks contaet ind leates the Gren Hountain sehist terrane' pases into that of the PInnacle forition without any break." Howerer, at no place has the selatia of the Tibbit li11 greenstone to the soh ats ast of $1 \mathrm{t}$ been definitely shown. It is entirely possible, as suggerted by minor structures, that the Tibbit H111 grenstone is underlain by roek of Ennale - vost sutton 11tholort.

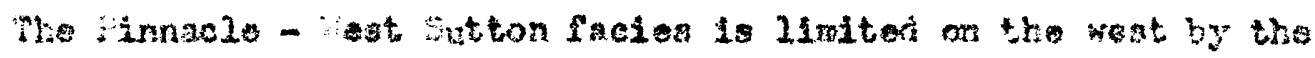




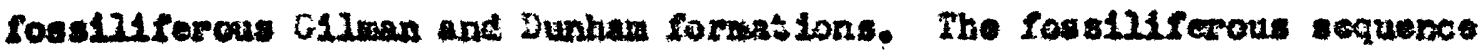
of nortimestern Formont is cut by eeveral thruat foults (Plate 4 ).

\section{Probiens of the geology of Northern Vermont}

Before attupting a discusalon of posalble corrilations between the Sustern and restern Vormont sequarees, it is necessary to wention several problems within the areas wioh are rather well mappod.

Foranost anong these problewe 1s that of the valudity of the rorthtouth correlation of the Battern Vermont sequence, uncontrolled by puleontologle oridence as 1t 1s. It is recognted, of course, that bourdaries of IIthic untts nood not necessarly corrocpend itth tive curfaces. There ean be no doubt of the north-aouth correlutlon of the disconforrity at the base of the Shav Mountain formation and it secas 11 taly that it corresponds rather elowaly with a the ourfece. The rather dintinctive Stowe formation contalne roloarle rocks throughout the state and 1 to uppor ari lowar contacts correspond rather eloely to those derined for the "Bethel schl ot" In the type 100ality. The absene of the stowe formation in wubeo has long bean problen in attenpts to corrsiate the section in webed with that in sout harn Versont. However, its gradual disappearance in northornost Vermont is rather well understood row.

The absence of a contimous Inney hollow type of rock below the Ottuugueciso has ade it defleult to dollneate the bose of the vtteu-

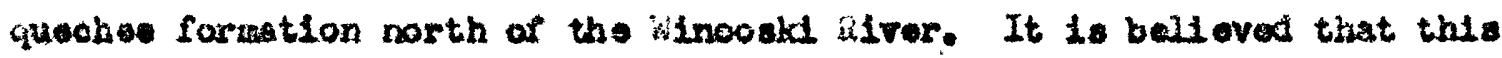

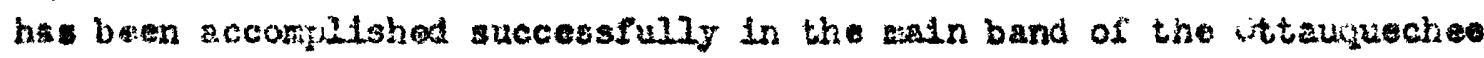
forsution, but it is rocognized that it has rot been posalblo to joline- 
ate securately botwen the Ottaugueohe formation end the Comel Hurp group in the Foot Brook arneline' An additional problem is the correIntion of the Otteuqueche formation erose the extensive area of cover nour Bden. Hownver, detalled mpping in the area has convinoed the author that the correlation is correct.

Tho corralation of the stowe and Ottauquebee formationa in the Foot Brook ornoline with the main bands of those formetsone has been discussed proviously. A large ancunt of tine has been apont trylng to whow concluatrel the raletton botween the rook mappod as stome formation in the Foot Brook aysalline and the tw couth-extending "prong" of the guarts-

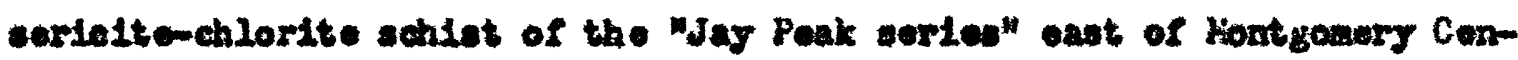

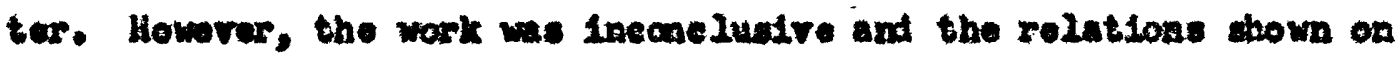
PIate 4 are based primarily upon 21 thologle oomparlsone rather than upon actual traced cantwets. The rock in the "prang" 10 a sirar-grwen

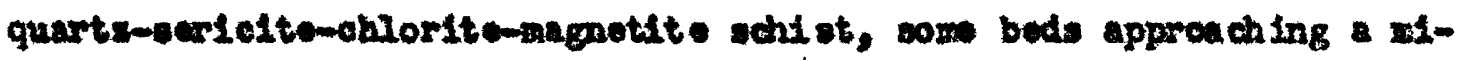
caccous quartatt of wile the Stowe farmation in the Foot Brook gyncline 18 a 1Iver-greon, quarts-sord elte-chloritemagnetite schiat, comucnly highly wlesewous and containing porphyroblasts of chloritold.

The majon structurad foatures are known gencelly, but have not jet bem rully delineuted. Thi 1, espeolally true of the unmapped areno ant of the shew Mountain formation. The variation in breacth of cutexp of the Cran H111 - Horstom forwationa 16 not jet explained. Prob2 in the unmapped areas in the Horth-central Vormont sequence w111 be discusad in the next section. 


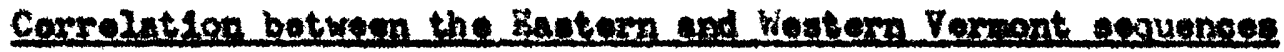

Any atterpt to corralate the Eavtern and Festern Vermont oequences In northern Verwont should wat upon the completion of geologio mapping In the rock designated bere as the North-eentral Verwont aequenee. llowovar. consideration of posalble correlutions does provide a userul tulde to direct further work.

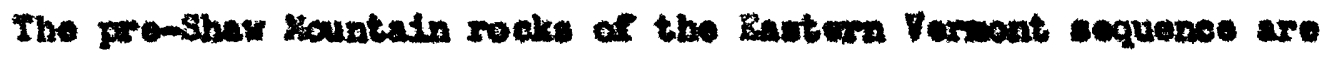
Cambrian and/or Ontoviclan. The Cran H111 - Xarotom formation is probably of Middle Oriovietan age, hones, the base of the Middle ordovician

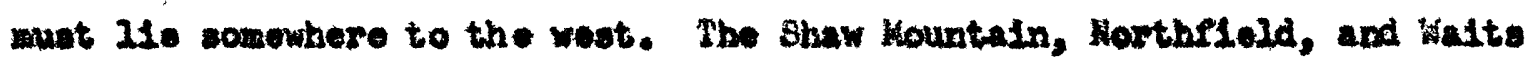
Hirer formations are not older than utddle ordoviatan nor younger than 2ate Deronian (kid te and Jahns, 1950, p. 291-192), but are probably Hiddie Ordorleian to 5ilurian (Boucot and others, 1953 ).

The promshaw Hountain rocke of the Bastern Vormont sequence way represent the wole eection from basal Casbrian (or oven late Precaubrian) to S1lurian. Howeror, giren the proper costination of unconformitites, these rocks ang represent only baenl Cajbrlan or only Hiddle Ordorician. In the iestern Verwont sequence axtensive unconforntties aro known above the Precambrien and at the base of the khtpple marble and Hortonv112 slate of Middle ordovician age. Hxtonsive uneonformities are present in the iastern Verwant sequenoe the base of the Shaw Nountain formation and above the Frecambrian core. Unconforeltios, probably inportant only 10eally, have been noted at the top of the stowe formation and at the base of the sorthfiela slate (sibte and Jams, 1950, 5. 187 ).

Three general corrations seen posalule on the basis of tis paleon- 
5010; fe evidesce alone. The Int arpretation wost generally accepted is that the pre-shaw kountain formations are equalvent in age to the can3ro-Ordovician sequence vest of the Green Nountains. Such an Interprom bation Inplies a rapld facles change from the carbanate equenee west of

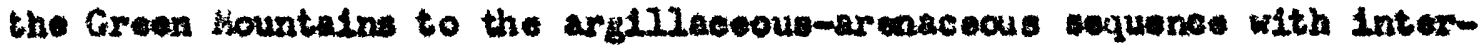
calated rolcante roeks on the east. Support for this feales change is found in the Indlow ares in the presene of quartatte and dolouite which are It thologloally einlar to parte of the Lowor Cambitan sequeneo west of the Green Nountalne. Further aupport is found in the fact that the

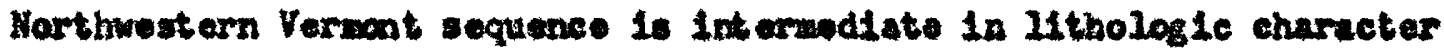
betwoen the eastern and weoturn equenees of central Vormont.

An alternative Intorprotation suggested by Thompen (B1IIInge and others, 1952, p. 28) is "that the premeram H111 formations are all of Midle Ordorleian age and to be correlated caly with the rock abore the mid-Ordovician unconformity weot of the sountain." such an interprom tation regulras thet an unconformity, a yot unxocognised, extends north from the point west of Warren wbere the frocanbrian rocks plunge urder the younger rocke. Thompson (perwomal cormunlestion, 1954) has sugested that such an unconformity may asily have resalnod unnotlced within the "graguacke" considered a Finnacle fomation Just west of the uroen fountains, inamuch as Ittle dotalled work ha boen within this critical $\operatorname{tr} 1 p_{0}$

A third posatble Interpretation is that the lowest Canderian claste rocks of the eatern Vernont gequnee are the squivalenta of rost of the

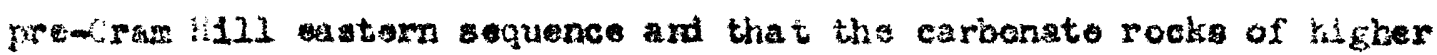


Cambrien and lowror Ondovician are represented by an unconformity, as jot

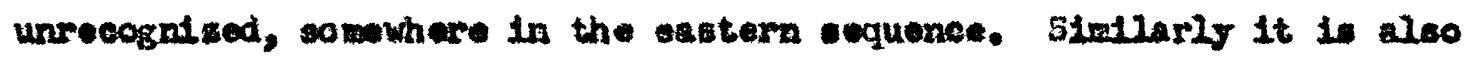
poselb 10 that the basel Hortonvill uncentormity 10 located within the biatern Vormont esquence rathar than at its base or at the base of the Shaw Nountain formation.

A wore detalled correlation ean be attenpted $a / y$ by the comparien of dotalled 2ithologle characterintes, or by tracing unito alang strike to pointe whe they "bridge" the Groen Hountain antiolinoriun in an ax-

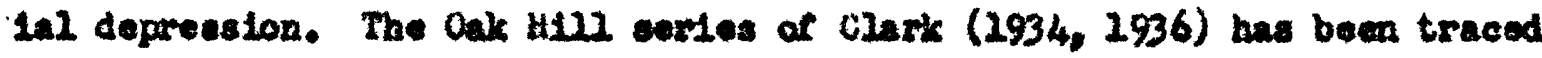

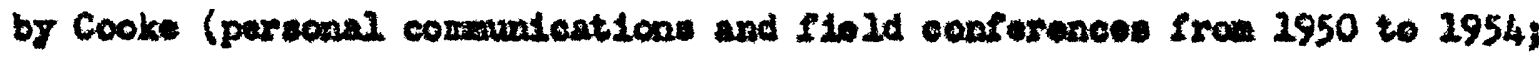
1954) neary 50 niles nortb of the International Boundary to the St. Franclo jiver. In the vielnity of Hichmond, wubee, on the st. irancis iliver, the Oak lisll eorles "bridges" the Groen keuntuln antielinarlum, Feconnaiseance by Cady and the author has mugested that the Sweotoburg slate, the Scotsmore quartalte, and possb2y the Oak H111 late and Dunhan doloadte, are the equivalents of the Hansonvile formation. If this correlation is valid, the Hensonville (and the Ottaupacines) formation exterals Iron Lowar Cabrian to Upper Canbrien In age. Reantif wore detalled work by $F$. H. Osberg (porsonsl comanieation, 1956, 2956) has confirmed thas tentative carrelation.

The Foot Brook analine offers anotber poseible "bridge" for a zore detalied east-west corrolation. As not od earls or tho rock in the foot Erook syncline has been correlated with the Stowe and Ottauqueches formations to the east, aw connis sance auggests that the "Jay Heak seres" is the equivient of the nest wutton schist and the innaclo 
"graywacke." However, it has not boen pousibie to desonstrate conelusively the rsiation between the "Jay Peak soriog" in the north end of th Poot Brook gycline and the "Stowe formation" In the southern exd. The rock in these two areas is lithologleally wombat disaimilar, but in an possLble interpretation rathor rapid tacles aranges aust be lllowed.

The difficults es in the Yoot Brook agnoline are compouncied by the presence of two posalble corrolatives of the Ottavqueches formation on the weat Slenk of the Green Hountain antielibarlum. One is a nerrow band (JPSg on Plate 4) of black phyllite and thin maentre quartzite with an underlying greanstone, soparated frow the albite schist of the Camels Hump group by allvermgreen quartz-nerielte-ohloritomagnetite schlst. The of her la the "agneline" of black phyllite, black quartalto, and black Iimestone nortierest of Jeffersonville (JPBB on Plate 4). The correlation of afther of these with the "Ottanquechee formation" In the Foot Brook syneline requires that the underlying ellvor-green quarti-serieit-chloritomagrat te schlot of the "Jap Peak ariea" thin to axtinetion eastward ss such a unft toos not appear In the Foot brook syneline. fithough! on the basts of lithologic compartion the black phyll1te, blacis quartz1te, and black limestone in the syncline northwest of Joffersonville (JPSb on Plate 4) may posalbly correlate watward wh the Hortorville formation, it sews wore $21 k$ ky thet theg corroluto westward with the Skeols Cornors alate (jweetsburs alate), Rugg Brook formation (jcots-

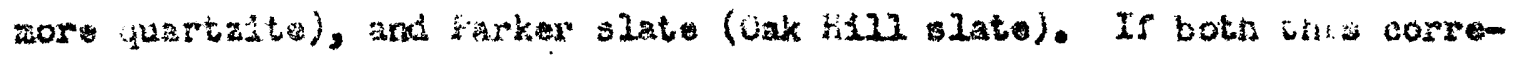

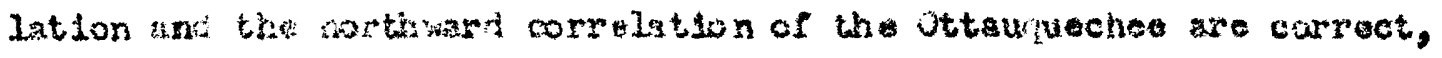
then the rocks in the syncline near Jeffermandile aloo correlate with

$$
125
$$


the ottanqueches formation.

Another poestb111ty is that the correlation of the rocks within the Poot Brook syneline with the jtow end Ottauquechee farmation is incorrect. The PLney Bollow formation is Lthologleally ginilar to the Stowe formation. The roek within the Foot Brook spolline way be the equiralent of tho Plnney hollow, thlnntag to catinction asatward, so that it does not appear in the eastern part of the Hyde Fark quedrangle. Juch a correlution would aggest ubat the Cttauqueche formation is absert in the Foot Brook ayneline, but appears in the "ayncline" (JPSb) northuset of Jofferearille. It would also ouggest that the unit ahoun as Ottauquechee In the Foot Brook syneline correlates weatume with JPSg: Several different corroletions are postble in attenpting to corrolate westward from the Hyde Park quadrangle by coaparison of Itholog10 characterlstice. To one of these oan be favored on the basis of what 18 now knom. It is belloved that detalled work around the two "bridges" w11 erentulis disclose the proper correlation. Further datellod nap ping within the North-central Vermant aquence will resolve sery of these

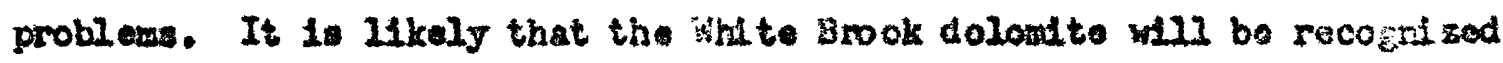
Wthin the "Jay Peak serles" and will groatly ald the correlation. Gsbars has clarifled the otructure and atratigraphy near kichnond, webec, but nore work is needed just nortb of the International Boundary before this knowledge can be completaly util1sed in nor thern Vermont. 


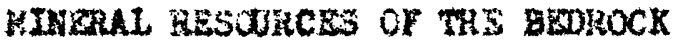

\section{Tale}

Tale is the most important mineral resource of the bedrock of the Hyde Park quadrangle. Since about 1900 sereral small wines have been worked internittently in large body of ultramafle rock, 2.6 miles $\mathrm{K}$. $39^{\circ} \mathrm{B}$. of tho cunter af Johnson r12zage. One of these, the johnson Kine (Chidester and othere, 1952, 8. 17-20, B2LLings and chideater, 2944) of the sestern Magnesis fale Conpan, as of Septembar 2954 was productug ground tale at the rate of about 22,000 toa anmaly. Ibe ultrabafis body is about 3,500 foet long and 200 foot whde. It is al-

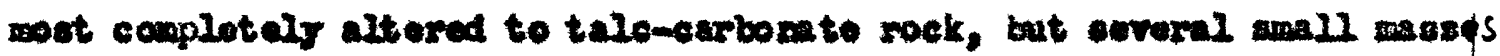
of sarpentinite romin at the couth ord of the mese. The carbonate,

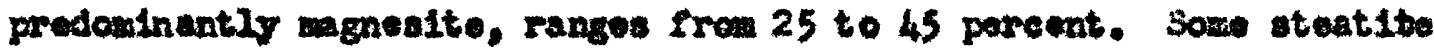

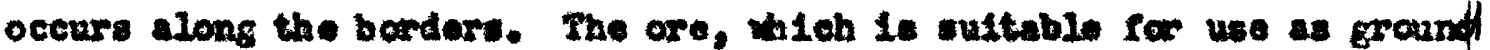
talc, is ground at a dil in Johnoon v112ge.

A all abandoned tele line (Chideet er, and ot hare, 1951, p. 20) 0.75 wle 3. $60^{\circ}$ \%. of the enat of Johnson v11lage, cont ains talccarbonate roek of good qunlity. The caved open plt 1 s about 125 by 40 feet, and underground workings are knom to he vextended sevaral hundred reet to the south.

Talemenrbonate rook it expoed for about 200 seot along the bed of

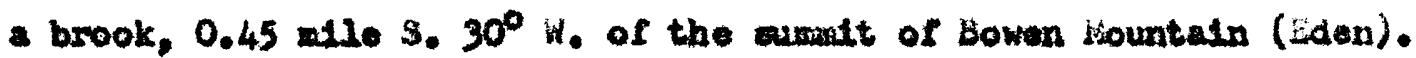
About $0.90 \mathrm{~m} 110 \mathrm{3}, 20^{\circ} \mathrm{H}$. of Bowen Mountain talo-oarbonate rook $1 \mathrm{~s}$ oxposed for about 150 fact in brook and in scattered outcrops for 450 feot north from the brook. The talc-carbonate rock is very witio, of 
good quality, and regosbles that at the Sohnson kine. The area between the two group of exposures is eoverad atth evrfletel dopontts, but bots occupg appraximately the eame atratigraphis postelon. About 700 feet up-

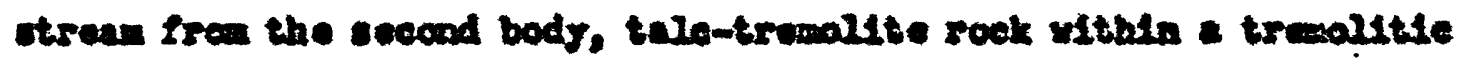

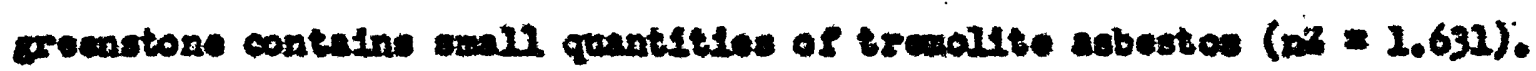
The conet axtent of th1 so oik wald wot be dotermined because of cover, bat 1 to does not eppoar to be rory ereat.

\section{Otber mblarel rescurese}

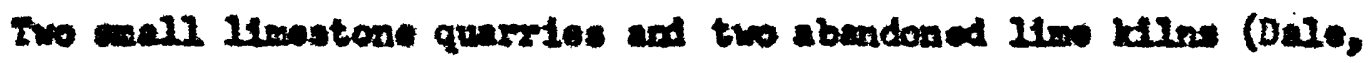
2915, p. 22-14) are located 2.20 wllos H. $21^{\circ} \mathrm{W}$. of H131ulde Sehool (Jahnoon). Tho beds of Impure aarblo are thin and ean not be traced far alang the strike.

sanll rednlete of galean and ophalorite and asoocleted pgrite and barlte are exposed 10 a sanll prospeet plt, 1.55 atles $3.5^{\circ}$ W. of

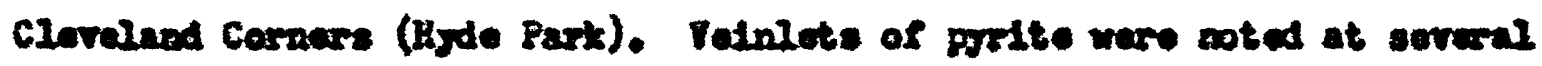
places in tho calcarwous sehtets is the rietnity.

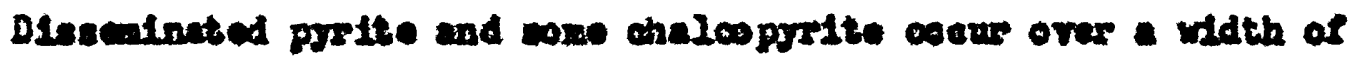
about 25 foet in grematone and a bleck abd nilte baoded quartalte in the

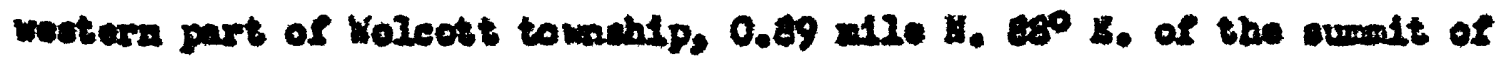
Toothecher Hill (Hyde Park). PIts, tromebos, and ihafts openad in a scarch for sopper, wo wr abendoned and fllled with water.

Imenite and kyanite are exponed in and around the vielnity of

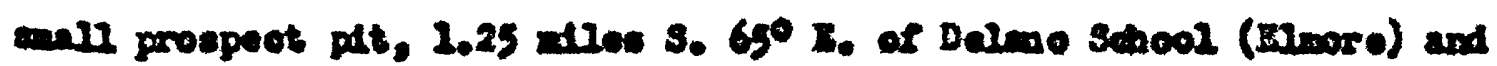

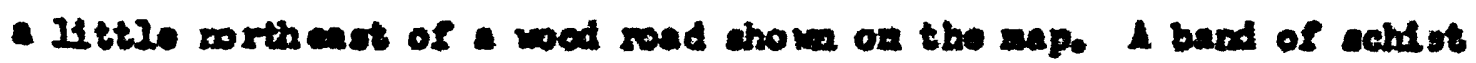


about 200 fert wide contains about 35 perent of partly altered krante

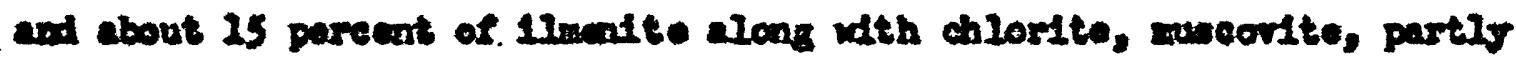
altard garnat, and seriefte and enloritold fornd during rotrograde

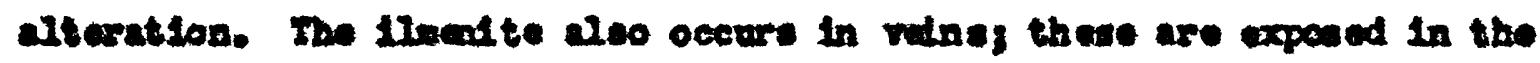

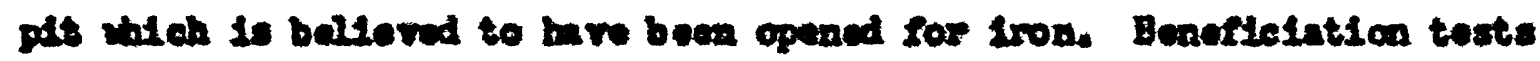
san on eamples froe this aroe Indteated that the kJanite eannot be cen-

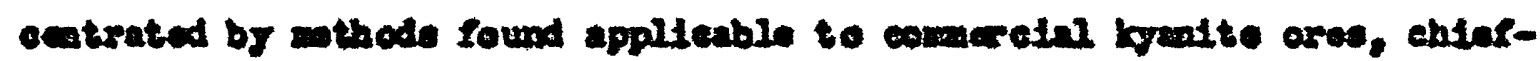

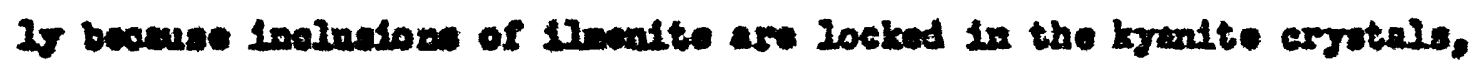

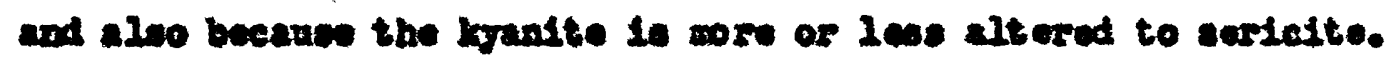




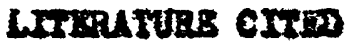

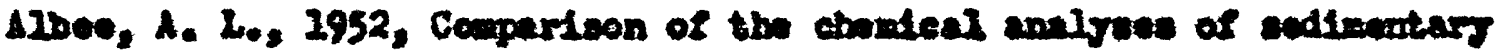

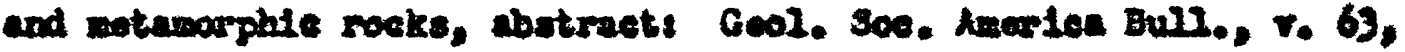
p. 2229.

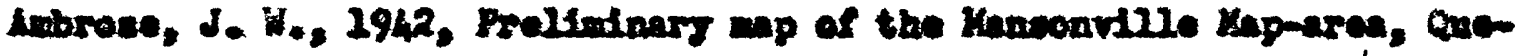
boet Cande Geol, Surres, Paper 42-1. 1943, Prollednary ap of the Stanuteed Kap-aros, Guobeer

Canada Geol. Sroves, Papos 43-12.

Balk, Robert, 2936, Structural and potrologte st wdtes in Dutchose CountJ. Now Torik Cool. 30c. Amer1es Bul1., V. 47, p. 685-850. 1952, Pobrte of quartatea near thruat fantes Jour.

C.01., 7. 60, p. 415-435.

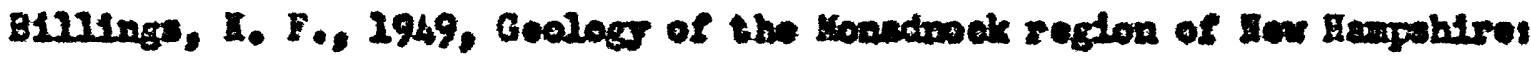
Cool, Soc, Learica Bull., 7. 60, po 1249-1280.

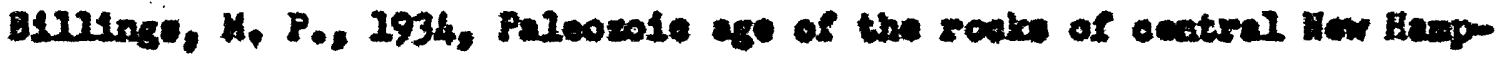
chlres satenee, 7. 79, p. 55-56.

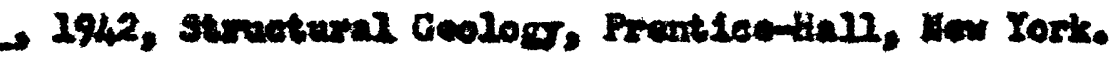
1954, Strueturel 0oologr, 2ad. ed., Prent10o-lall, In Torik.

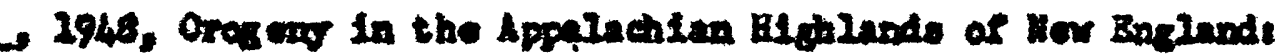

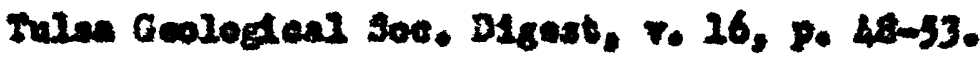
and Chidester, A. H., 194h, the Jolmaon tele nine, 8000 Iogle surface mo swolocte wap of the 200-foot Iornt, streture

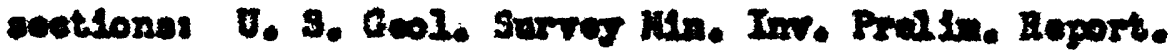


Jodgore, John, and Thompsen, J. B., Jr., 1952, Geolobs of

the Appalachina HIghlande of east-central New York, southern Formont,

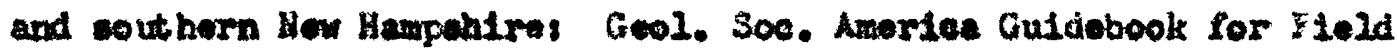
Trip in biew ingland, 65th annual weoting, p. 2-71. 1955, Goologle map of New Hampohires the Heu hampentre Planning and Development Comos Dir. of Geal. Beionces, Harrand Untr. and the U. S. Geal. Surrey. 1956, The Geologe of New Hampahire, Part II, Bedrock

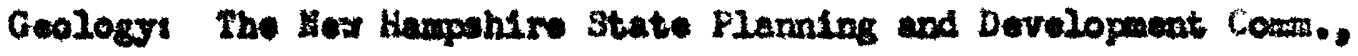
Conecerd, H. H.

Boardman, Leane, 2952, Index to Geol. Kepping in the U. S. Strates of Wow Haspentre and Vormonts U. \$. Gool. Surver. Booth, Y. H., 1950, Itrat1graphy and etructure of the Oak Hill succes- Lian in Vormont: Geal. Soc. Amarice Bull., V. 61, p. 1131-2168. Boucot, A. J., Harnor, A. S., Madanald, G. F, and N1ton, Charles, 2953, Age of the Berwardston farmation, abstract: Cool. Soc, hater1ca Eul1., v. 64, p. 1397-1398.

Brace, $W_{0}$. F, 1953, The geology of the Futland area, Vermants Venwont Cool. Survey. Bull. 6. Cady. W. K., 1945. StratIgrephy and stucture of vest-central Vernont: Geol. S00. Arearlea Bu21., v. 56, p. 515-558. - 1950, fordil ap coral from the tomorphic rocks of central Verwont: im. Jour. 3ct., v. 248, p. $48 \varepsilon-4,97$. , 1956, 3edrock geolody of who lontpelfor quadrangie, Tar-

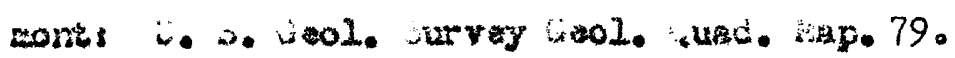


Chang, P.H., 1950, 3tructure and notworphian of the Bridgonater-fioodatook area, Vermonts unpublishod ih. D. Heste, Harrard Univ.

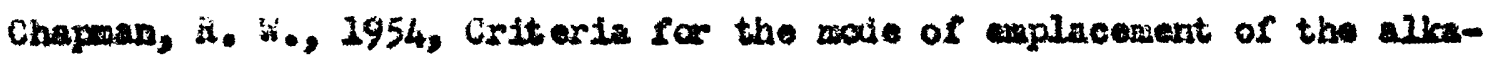

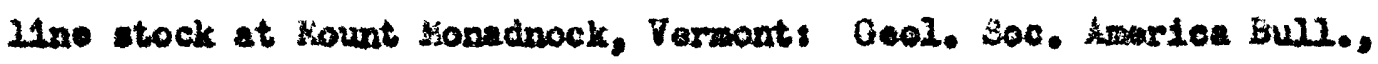
v. 65, p. 97-2u.

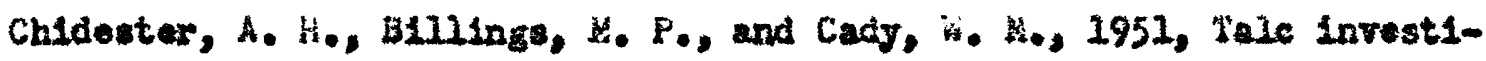
gatlons in Vemont, pelininary report: U. S. Gaol. survey Circ. 95.

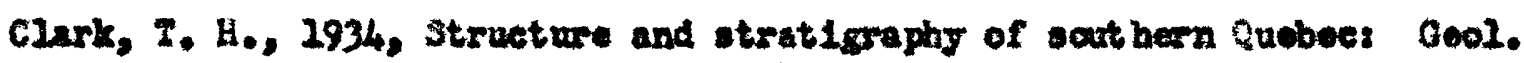
Soe. Anerles Bull., r. 45, p. 1-20. 1936, A larer Candian serf es from southarn lubect

Mogel Candilan Inst. Trene., P. 1, ., 21, p. 135-151. Clarke, F. H., 2924, Data of Geochametry 5th ad., U. 3. Geol. Survoy EuIl. 770 .

C1008, srnest, 1937. Interpretation of cryatelline rocks of Haryland: Cool. Survey haryland, T. IIII, P. 27-108. 1946, Linention; a crition review and annotated bibliography Gool. Soc. Amerlea hasolr 18, $122 \mathrm{pp}$

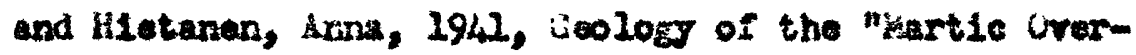
thruat" and the Glenarm Gerles in Fennsylvanta and Kargland: Geol. Soc. Amarlca, Spocial Faper 35. Cooke, H. C., 1950, 3atern Fownshlps of uobee: Caneda Col. Surroy howoir 257. , 1954, the Green Hountain sinticlinoriux in oneber ceol. Assoc. Warada Proce, v. 6, Ft. 11. 


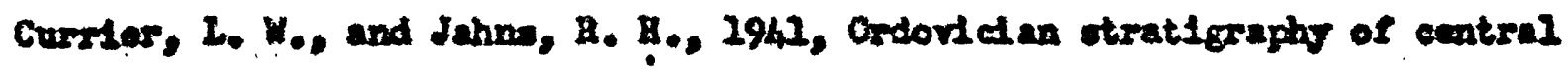
Vermont, Geol. 30c, Aacios Bull., V. 52, p. 1487-1512. De10, I. B., 1096, Structural dotalls in the Greec Hountaln reglon and In eastorn Ine Iorkt U. S. Ocol, Swrey, 16th Ana, Inpt., Pt. I, D. 543-570.

1915, The calefte ante and dolondte of eastorn Vermonts

V. 3. Coll. Survey, Bull. 589.

Do21, C. C., 2945, A prollninary ropart on the geoloss of the Strafferd

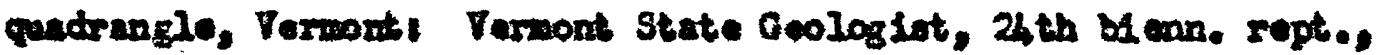
1943-44, P. 14-28. 1951, G001080 of the Kemphremageg quadrangle and the southcantarn portica of the Irasbure quadrangle, Terwont: Termont Geol. Server Bull. 3.

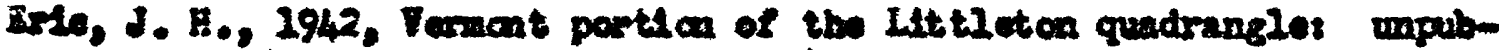

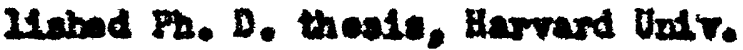
Bupter, B. P., and Toder, H. S., Jr,, 2955, Paragentter Carnegle Inut1tutsan of Washington Yoar Book Ho. 5h, for the jaar 1956-1955, po 124-126.

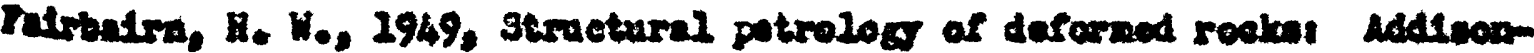
Wouleg Prose, Inc., Cambidgo, Hase., 344 Ppo.

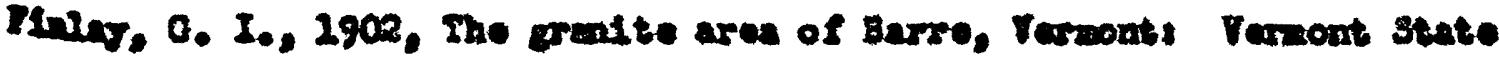
Geologlet, 3rd blown, ropt., 1901-02, D. $46-60$. Pouder, Pull1p, 1950, Strat1graghy and strecturs of the Cantletce area, Vormenti Vareant 0eol. Surver, Bull, 2. 
Kalth, 3. B., and Baln, O. H., 1932, Chrysot110 asbostosi I. ahrysot1le reinas Ecoa. Qeologr, T. 27, D. 169-186.

Inonen, Ph. H., 2938, Cbservatione and experimants on ptyonat1e folding: Soc. geol. Finlande, Comptos Bundus, no. 12, po 11-27.

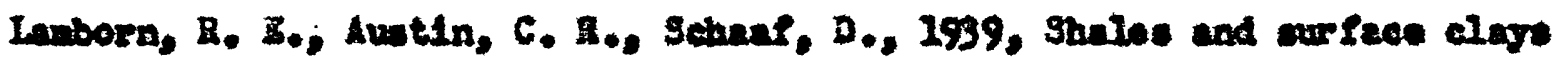
of Oblos Ohto Geol. Strerey, bth ser., Bull. 39.

Letth, C. I., 1905, Roek elearager v. S, Geol, Survy, Bull. 239. , 1923, Struetural geologrt 20x. Ad, H. Holt Co., Hew York.

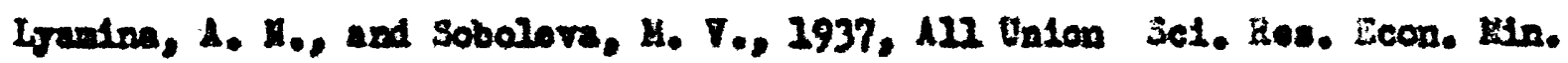
Koseow, no. 110, K1a. Abst. -8-334.

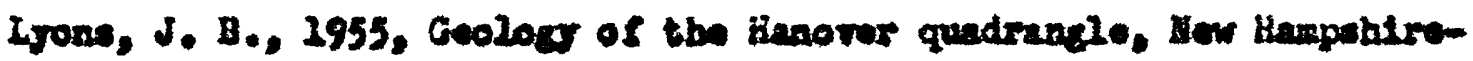

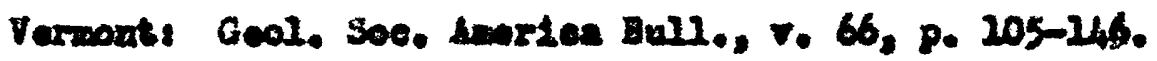

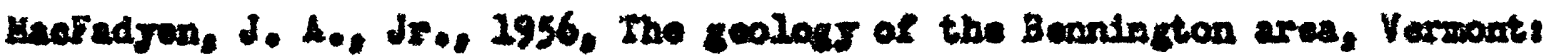
Tornout Cool. Surver, Bull. 7. Mead, W. J., 1940, Studies for students: folding, rock flowage, and foliate structures: Jour. Geol., v. 48, p. 1007-1021.

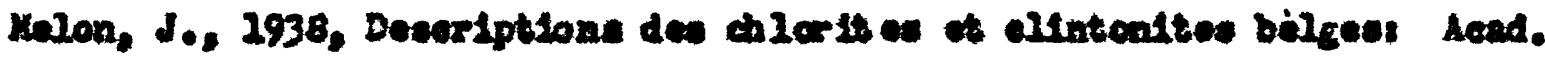

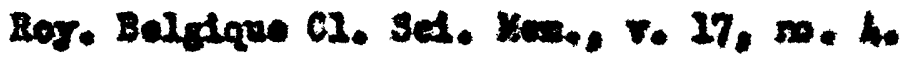

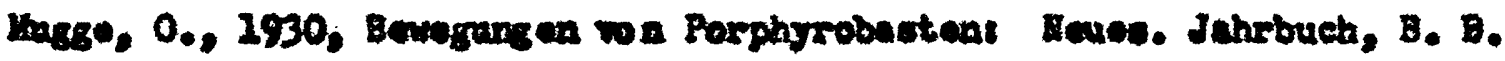
61, p. 469-508.

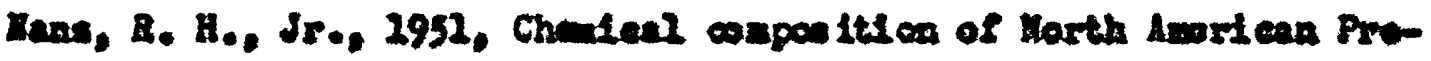

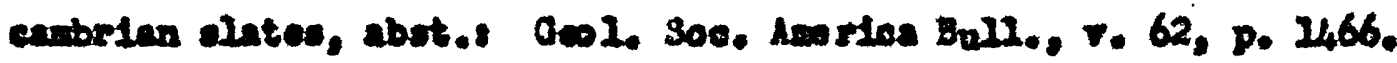

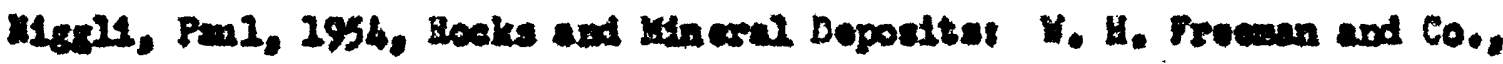
San granclaco. 


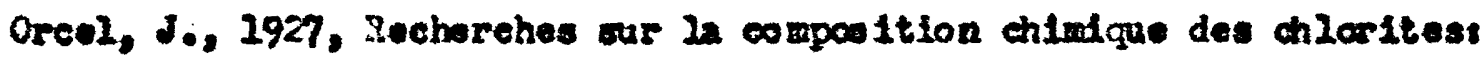
Soc. Franc. Min. Eull., T. 50, p. 75-454.

Oeberg, P. H., 1952, The Green bountain ant lelinorlum in the ricinity of Rochester and Zast HAdilobury, Verwont? Versont Geol. Survoy, Bull. 5.

1956, Stratigraphy of the Sutton Kountains, Suobees Key to stratigraphie correlation in Verwont, sbstract, Geol. Soc. Aleoriea Bull., 8. 67, P. 1820.

Pauling, Linus, 1930, The atructure of the chloritess rroc. Hat. Acad. Sed., USA, r. 16, P. 578-582.

Pottijokn, F. J., 1949, 3edtwentary Locks! liarpor and Bros., New York. Paillips, A. H., and Hess, H. H., 1936, Ketemerphie differentiation at the contacte botween serpent in and siliceous country rockst Ast. Min., $\nabla_{0}, 21$, p. 333-362.

Frepolly, I., Wolf, J. R., and Dal e, P. H., 1894, Geology of the Green Kountelns in Kansachusettes 0. 3. Gool. Survey Hon. 23. Parry, I. L., 1927, Swwary report on the gology of Plyouth and Bridgewater, Tomont Stato Geologdst, 15th blenn, rept., 1925-26, p. 160-162. 1929. The ge0logs of Bridgewater and Flywouth tornohlfe, Vorwont, Vermont State Geologist, 15th bienn, ropt., 1927-28, p. 1-64.

Alebardeon, C. H., 1902, The terrance of Crange County, Vorrecnts Verwont 3tate Geologlet, 3rd blenn. ropt., 1901-02, p. 61-101. 
, 1906, she areal and voonoutc 8 e0logy of northeastern Varmont, Vermont State Geologlet, sth bienn. rept., 1905-06, p. 63-115. 1912. The terranes of Craftebury: Verwont State 00010gist, eth blenn. ropt., 1911-12, p. 147-161. and Colltetar, H. C., 1912a, the terranos of Albary: Verwont state 0oolog 10t, oth blenn. ropt., 1911-12, p. 162-183. , and Comug, $\hat{A}_{0}, ., 1912 \mathrm{~b}$, The temranes of Iraaburg: Vorwont State 0oologiat, Bth bienn. ropt, 1912-12, p. 146-161. , Erainerd, A, Z., Joner, D. J., 1914a, The geology and minaralogy of Herdwak and Voodburg. Vemont Vermant State Coologtot, 9th blemn. rept., 1913-14, p. 294-336. , and furmer, H. O., 1914b, The tarranes of Greanaboro: Vermont State Geolog1st, 9th bienn. rept., 1913-14, p. 277-293. 1926, the geologs of Galalo, sat Hontpaller, and Borlin, Vermont: Vermont state Ceolog1at, 10th bienn, rept., 1915-16, p. $121-149$. , 1919a, The oxdoviclan tarranes of oentral Vezmont: Varwont state Coologist, 11th blenn. ropt. 1917-1918, p. 45-51. and Canp, S. H., 1929\%, The terranes of torthrield, Venont: Vermont state Geologist, 21th b1em. rept., 1917-18, p. $99-119$. 1924. The terranes of Jathel, Vermont Vermont itato frologist, 14th biens. Fopt., 195-3-2it, pe 77-103. 1927, Tho seology and retography of Barard, Pontrot, and roodstock, Vermont: Vormont istate Geolocist, 15th blenn. ropt., $1025-36$. 2. $127-159$ 
koserfeld, s. L., 1954, Geolog of the southern part of the Chester Dowe, Varmont: unpublished th. 6 . thesis, harvard Univ. Shaw, A. i., 1949, Stratlgespy and structirs of the st. Albans ares, Vermont, unpubllatsed In. D. thesis, Harvard Unir. 1954, Lower and lower lifdale Cambrian faunal succussion In northestern Varmont: Ceol. Soc. Arerkea Bull, . 65, p. 20331046.

S1mpen, B. S., 1936, Contuributions to the uinernlogy of western Australle Jour. Woy. Soc. N. Autralla, ,. 15, p. 3.

Skechan, J. in., 1953, 000logs of the kilmington, Vemont arest unpublishod Ph. D. thesis, Harvard Untr.

Stone, S., 1951, Geology of the K1.2tan, Vermont aveat unpubllahed Fh. D. thesis, Harvard sniv.

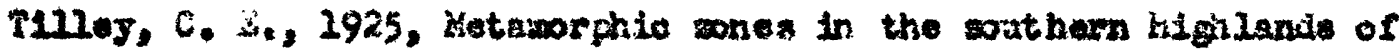
Scotiand: Gol. Soc. London luart. Jour., v. 81, p. 100-112. 2938, The statua of hornblende in 20w rade tamorytac nons of geen echlots: Geol. raze, r. 75, p. 497-511.

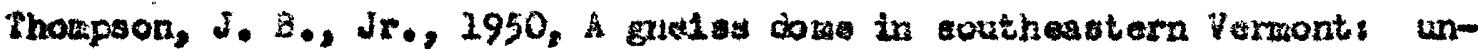
publishod Ih. D. theela, Wass. Inst. Fech. 1955, the themotiynamic basla for the mineral facies concepti su. Jour. 501., v. 253, D. 55-103. rurner, F. J., 1948, wolution of the tampic rooks weol. joc. Aperice, Fin. 30 .

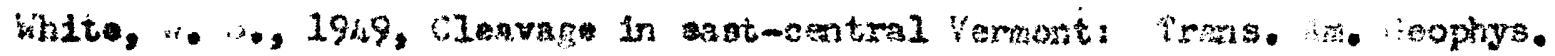
Unlon, $v .30,0.587-594$ 

and Jahns, $K_{0} k_{*}, 1950$, Structure of contral and enat-central Vermont: Jais. Vol, v. 58, p. 179-220.

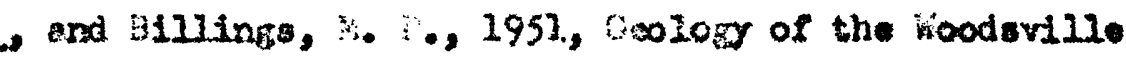

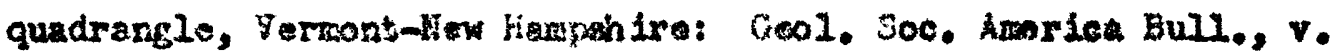
62. p. $647-696$.

Whittle, C. L., 1894, the occurrene of Algonikian rock in Vermont: Jour. Gool., v. 2, p. 396.

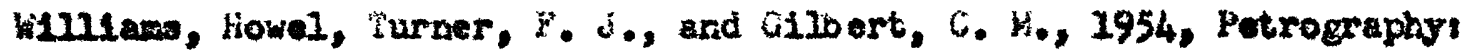
W. H. Freanan and Co., San Kronclseo. Winchell, A. H., 1936, A third study of cilorites Am. Hin., r. 21, p. $642-651$. 1931, Slements of optios nineralogy, pt. II. wiley. H.

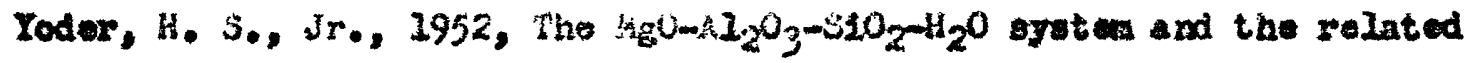
netasorphic Iacies: Asl. Jour. Sci, Jearan Vo1., p. 569-627. , and sugster, $1.9 ., 1955$, Synthatic and mintal muscoviter Osochen. ot Cosmochera. Acta, v. 8, p. 225-280.

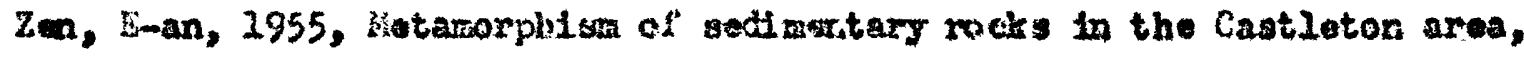
Vermont, unpublished 7 . O. the sis, fiarrard Unir. 
है सै

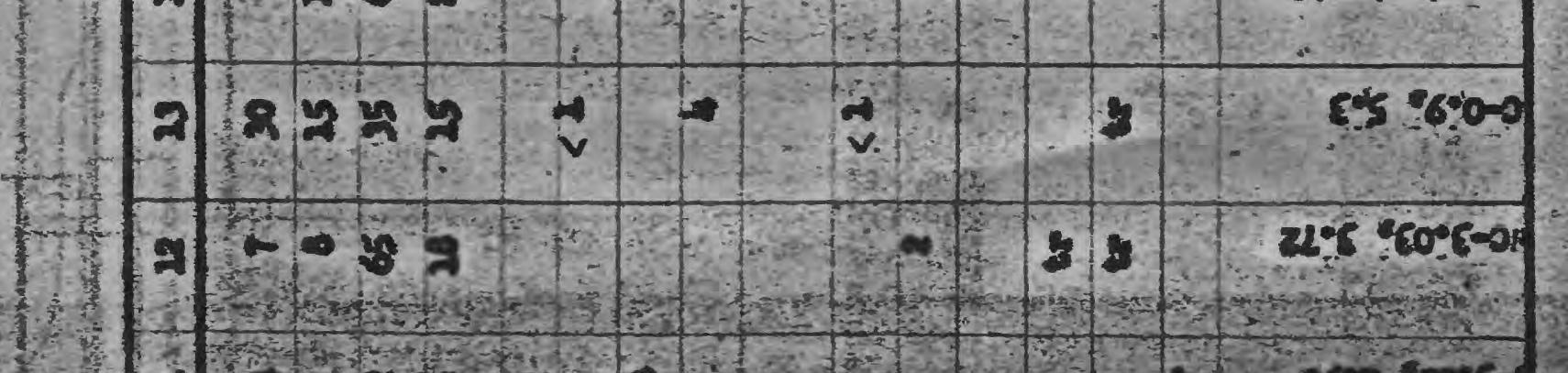

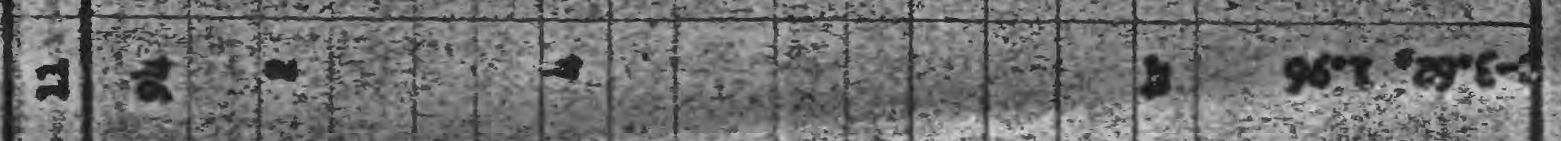

9.

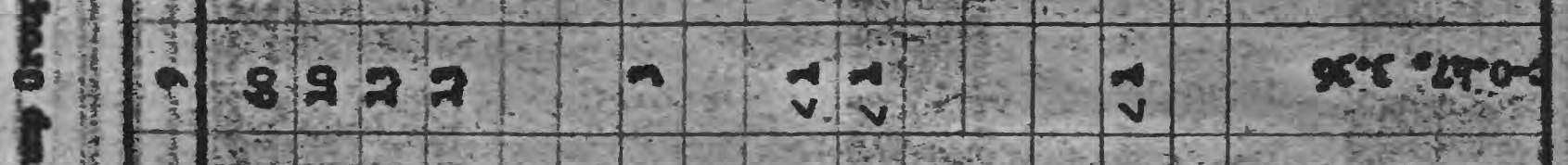

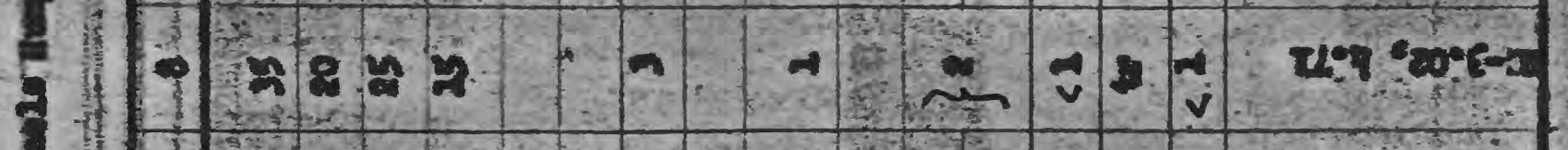

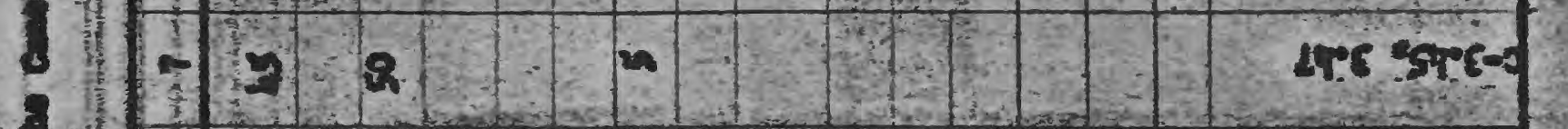

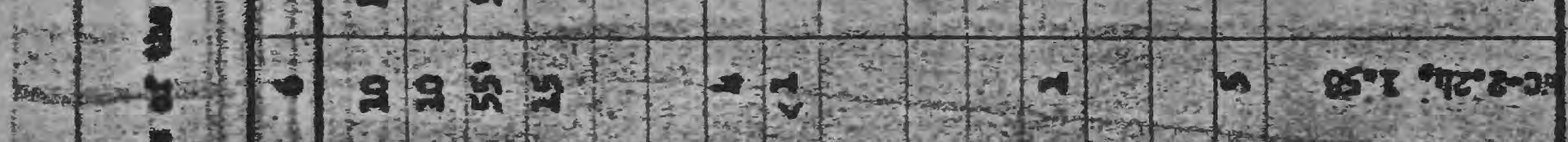

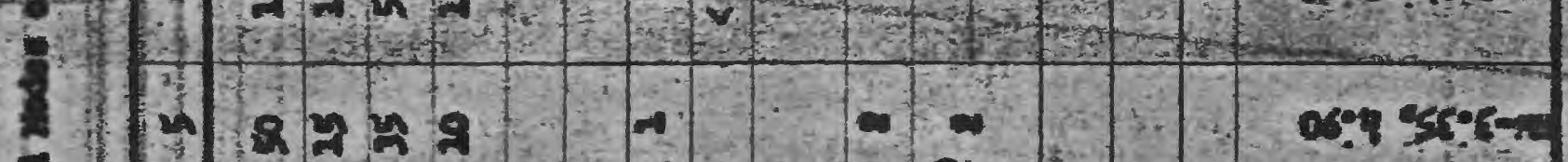

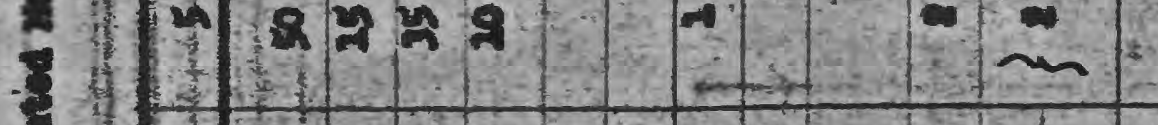

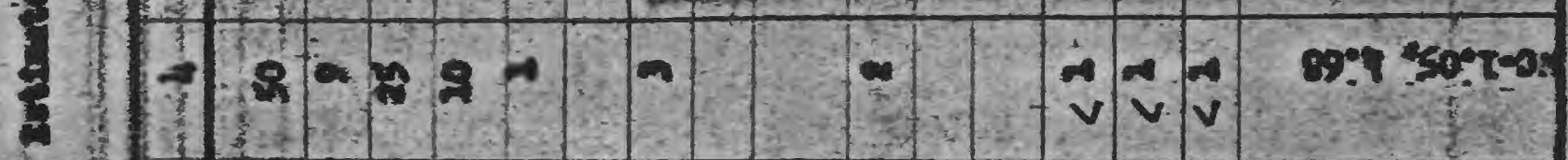

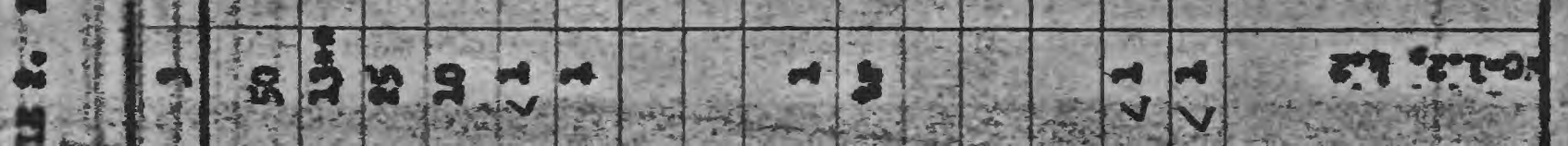

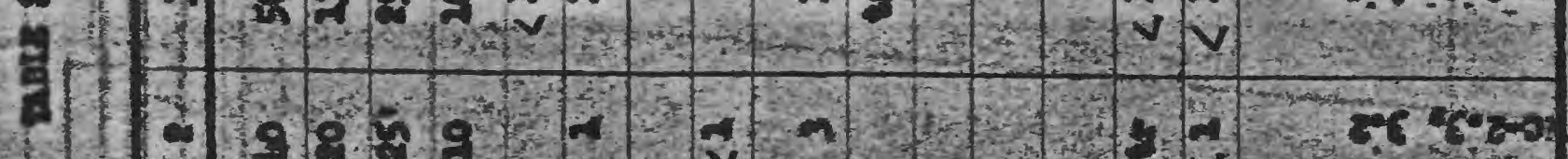

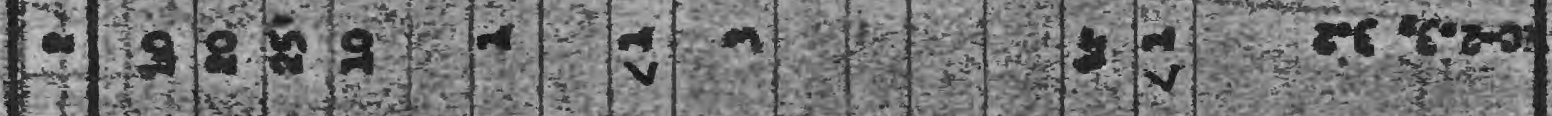

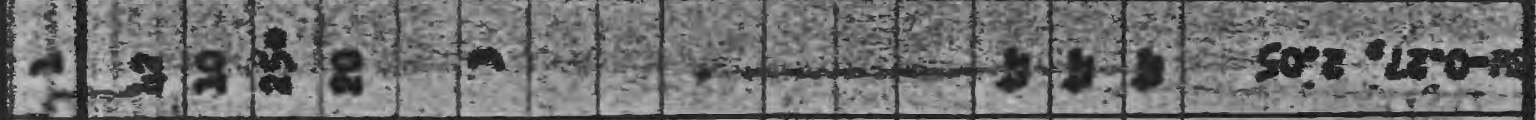

है

हैं हैं है है

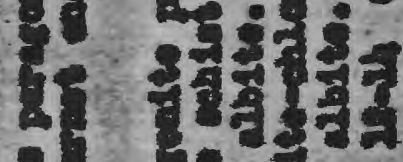

38. $4 \sin ^{2}$

Fुํำ

H. ${ }^{2}$ का

- 8 경

บ 5 ,

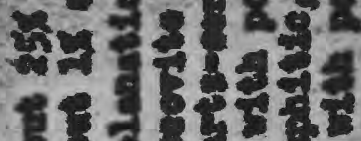

दैं क्री

: 1 


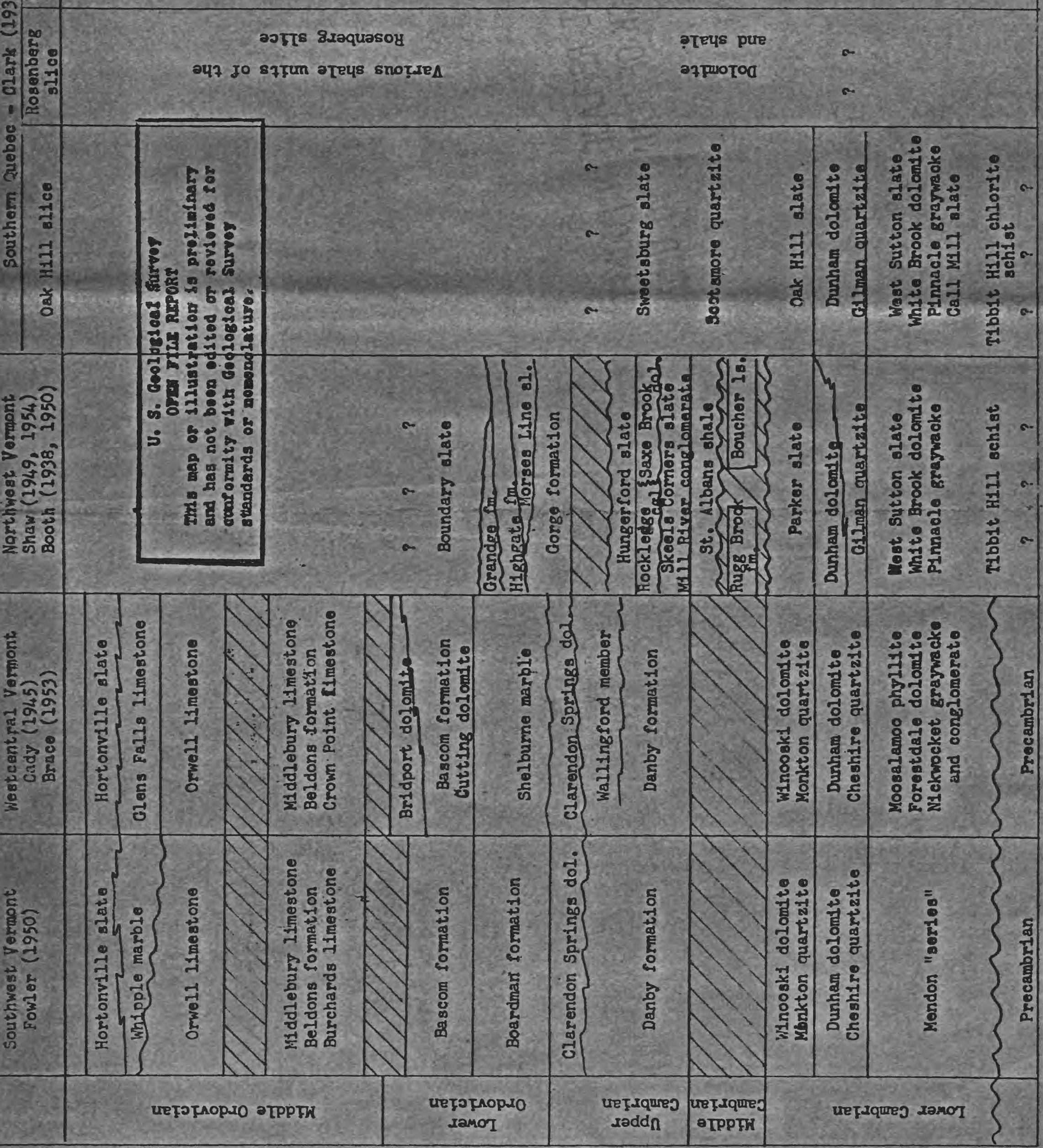




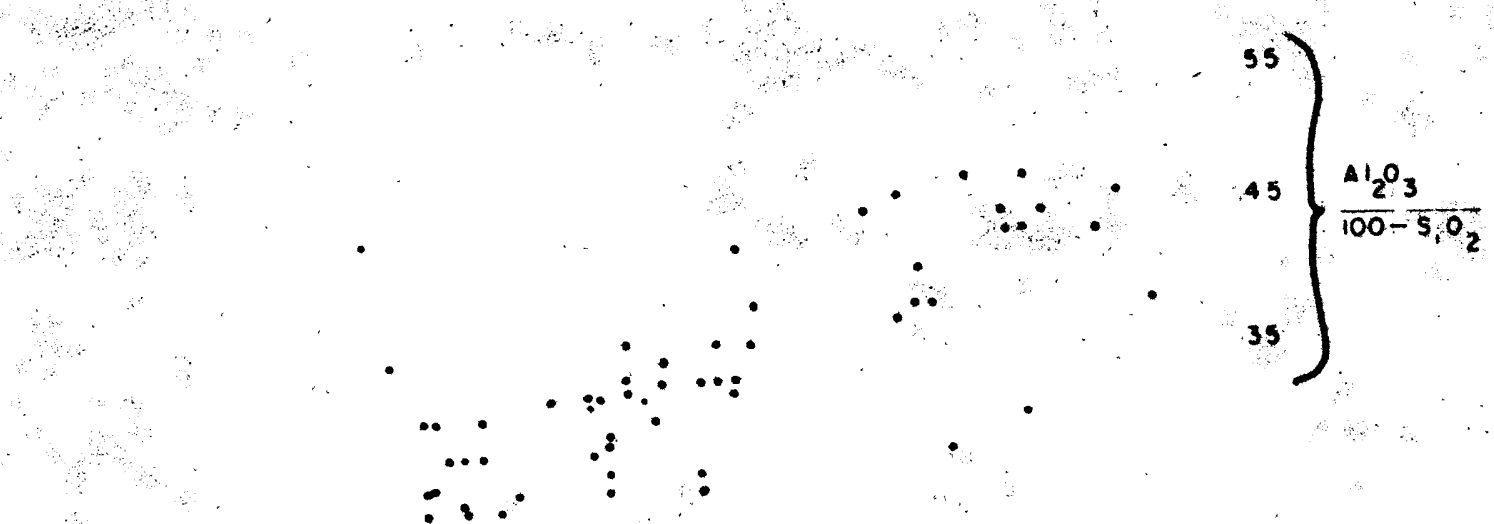

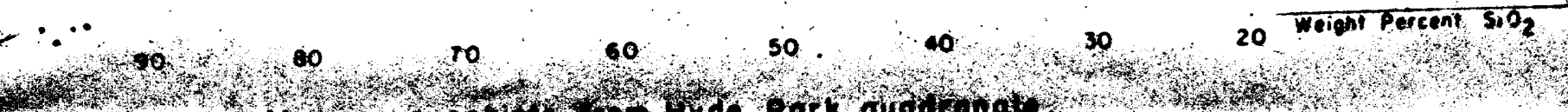

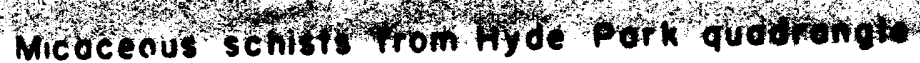

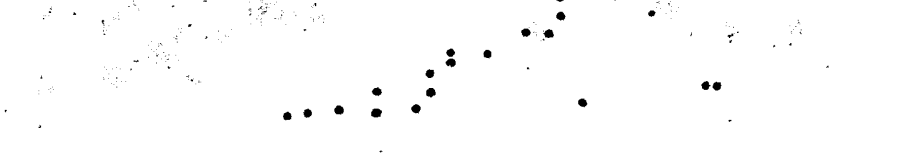



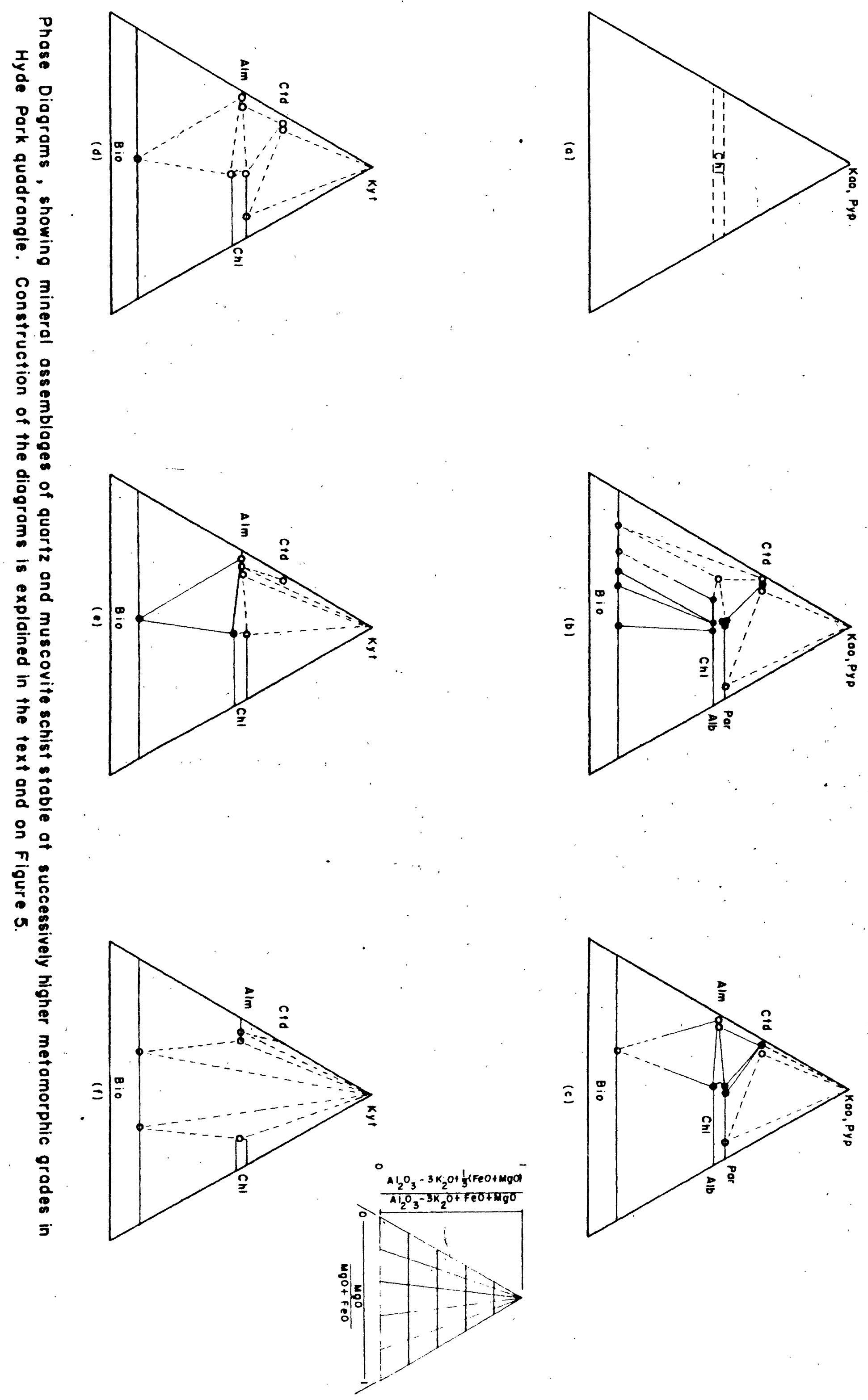


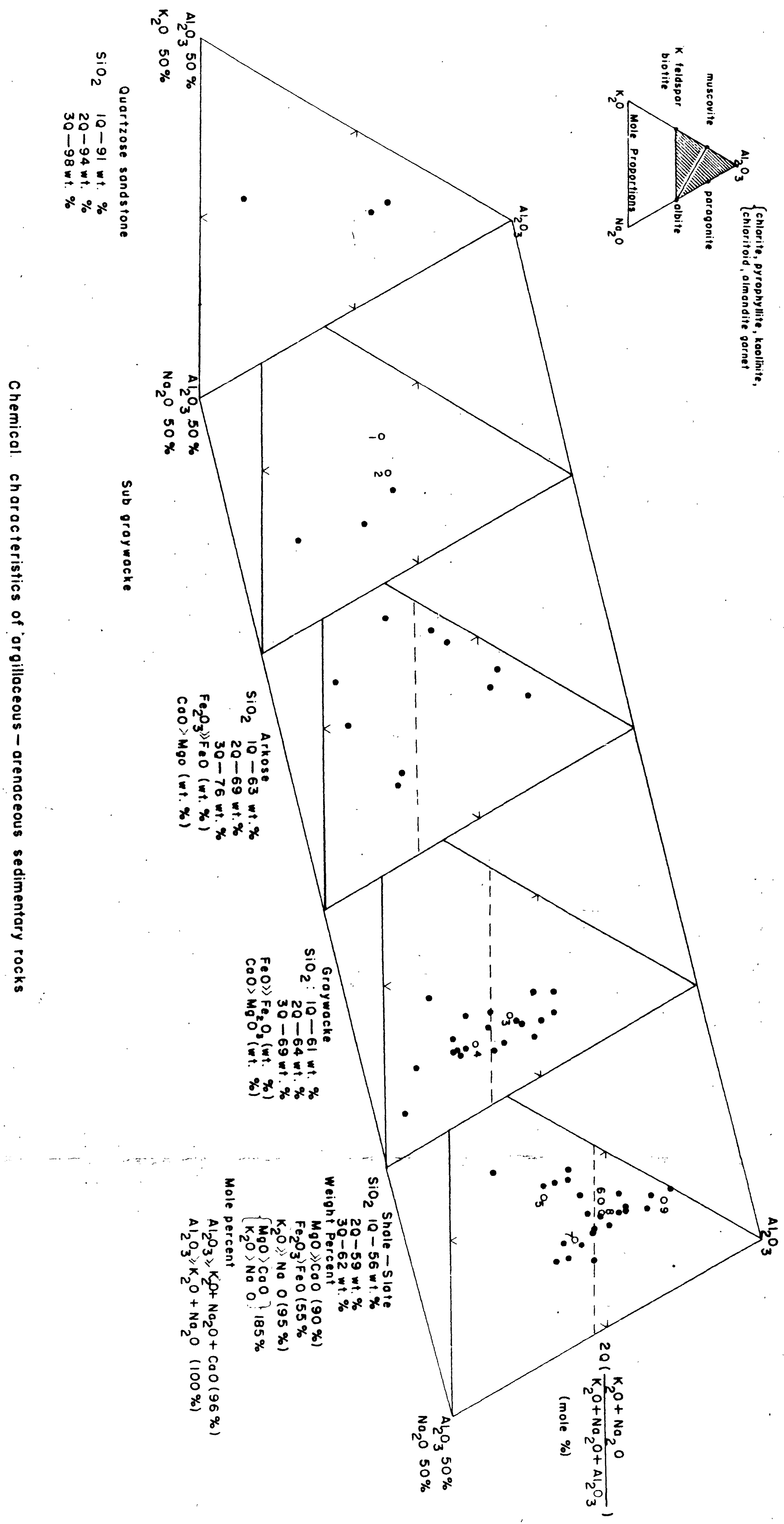




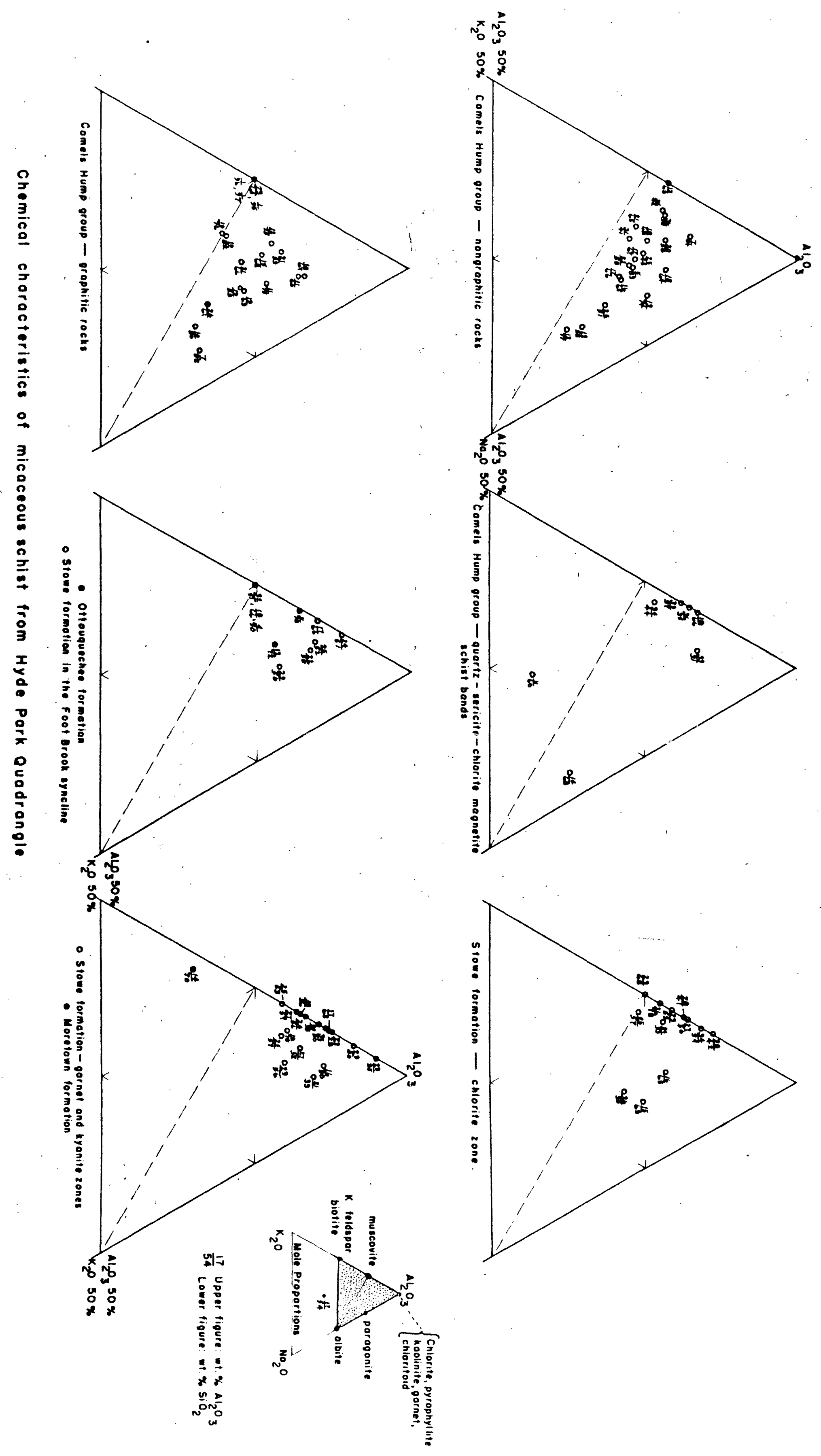

暍 


\begin{tabular}{|c|c|c|c|c|c|c|c|c|c|c|}
\hline \multirow[b]{2}{*}{$\begin{array}{l}\text {. } \\
\text { 睎 }\end{array}$} & \multirow[b]{2}{*}{ 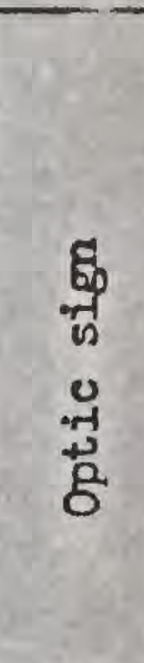 } & \multirow[b]{2}{*}{ 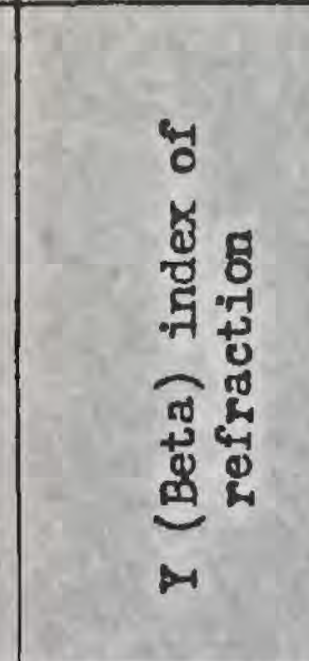 } & \multirow[b]{2}{*}{ 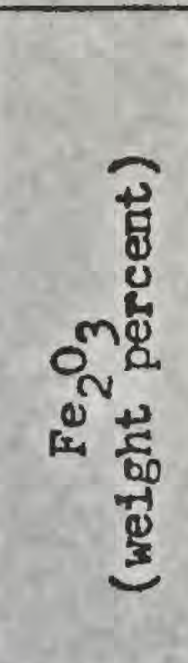 } & \multirow[b]{2}{*}{ 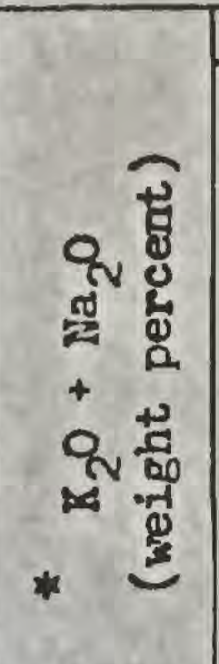 } & \multicolumn{4}{|c|}{ Mole percent } & \multirow[b]{2}{*}{ Occurrence } & \multirow[b]{2}{*}{ Source } \\
\hline & & & & & 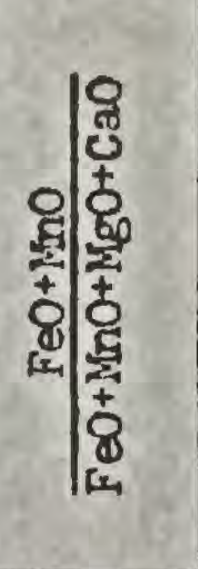 & 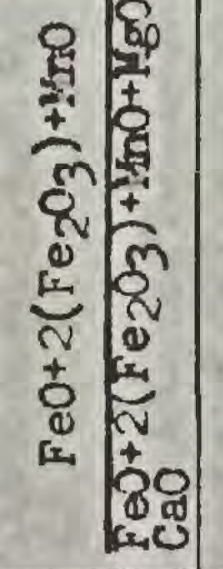 & 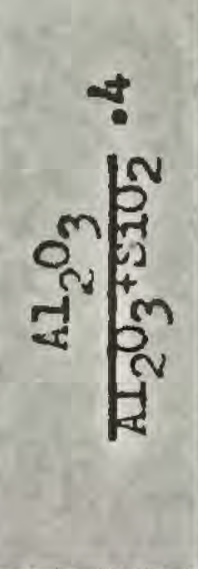 & 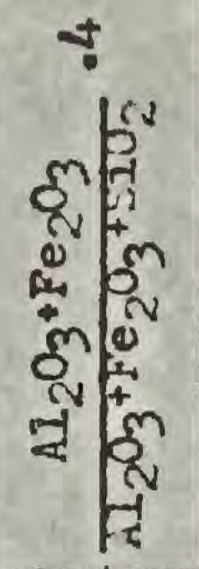 & & \\
\hline 1 & & 1.642 & 2.20 & .00 & 67 & 68 & 1.46 & 1.52 & Argillaceous slate. & Zen, 1955, p. $27(197-2)$ \\
\hline 2 & & 1.636 & 1.70 & .00 & 64 & 65 & 1.47 & 1.51 & Argillaceous slate. & Zen, 1955, p. $29(212-2 \mathrm{~A})$ \\
\hline 3 & - & 1.628 & -72 & .13 & 50 & 50.5 & 1.35 & 1.37 & Chlorite-epidote-calcite-albite schist. & Osberg, 1952, p. 59 \\
\hline 4 & - & 1.638 & 2.08 & .00 & 61 & 63 & 1.37 & 1.42 & Quartz-albite-chlorite-muscovite schist. & Osberg, 1952, p. 49 \\
\hline 5 & - & 1.627 & 2.43 & & 46 & 48 & 1.41 & 1.47 & Argillaceous schist; garnet zone. & Skehan, 1953, p. 138 \\
\hline 6 & + & 1.620 & 2.82 & .31 & 41 & 43 & 1.27 & 1.34 & Greenstone. & Tilley, 1938, p. 497-511 \\
\hline 7 & $\bullet$ & 1.622 & 3.88 &.$\infty$ & 44 & 51 & 1.31 & 1.41 & Greenstone; albite-chlorite schist. & Hutton, 1938 , p. 198 (2586) \\
\hline 8 & + & 1.623 & 3.49 & Tr & 43 & 49 & 1.20 & 1.29 & Albite-epidote-chlorite-sctinolite-calcite schist. & Hutton, 1938 , p. 198 (2718) \\
\hline 9 & + & 1.608 & 3.85 & & 25 & 30 & 1.37 & 1.59 & Quartz vein in phyllite. & Melon, 1938, p. 19 \\
\hline 10 & + & 1.602 & 1.93 & & 20 & 23 & 1.41 & 1.46 & Quartz vein in phyllite. & Melon, 1938, p. 23 \\
\hline 11. & - & 1.638 & 4.48 & & 60 & 63 & 1.52 & 1.63 & Quartz vein in phyllite. & Melon, 1938, p. 25 \\
\hline 12 & + & 1.636 & 4.86 & ${ }^{\prime}$ & 52 & 56 & 1.44 & 1.55 & Quartzite. & Melon, 1938, p. 31 \\
\hline 13 & + & 1.615 & 1.64 & .03 & 39 & 40 & 1.21 & 1.26 & "Black wall zone" at serpentinite contact. & $\begin{array}{l}\text { Chidester, written communication } \\
(I D-50-2009)\end{array}$ \\
\hline щ & \pm & 1.626 & 3.4 & .2 & 49 & 52 & 1.35 & 1.44 & Albite dike with muscovite and sphene in metrmorphle rock. & Agar and Bmendorfer, 1937, p. 77 \\
\hline 15 & & 1.663 & 1.99 & & 91 & 91 & 1.80 & 1.85 & Cavities in bauxite. & Lvamina and Soboleva, 1937 (M.A.-8-334) \\
\hline 16 & + & 1.585 & 1.46 & .04 & 17 & 19 & 1.27 & 1.30 & Groenstone, & Simpson, 1936, p. 3 \\
\hline 17 & & 1.592 & 2.04 & 1.24 & 13 & 16 & .96 & 1.03 & "Black wal1 zone" at serpentinite centact. & Phill1ps and Hesa, 1936, P. 340 \\
\hline 18 & + & 1.613 & 2.76 & .62 & 30 & 33 & 1.22 & 1.25 & "Black wall zone" at serpentinite contact. & Phillips and Hess, 1936, p. 340 \\
\hline 19 & + & 1.618 & 1.90 & & 35 & 37 & 1.27 & 1.32 & $\begin{array}{l}\text { Chlorite schist associated with feldspathie amphibolite } \\
\text { and cut by quirtz-copper voins. }\end{array}$ & Orcel, 1928 (93) \\
\hline 20 & - & 1.651 & 1.86 & & 74 & 75 & 1.38 & 1.43 & Chlorite vein cutting hemstite bed. & Orcel, 1928 (123) \\
\hline 21 & - & 1.667 & .67 & .35 & 91 & 91 & 1.49 & 1.51 & In "iron bed" with hematite and magnetite. & Orcel, 1928 (128) \\
\hline 22 & & 1.588 & 2.00 & & 8 & 11 & 1.03 & 1.08 & Tremolite-chlor1t,a sehist. & orcel, 1928 (170) . \\
\hline 23 & & $N_{\text {av. }} 1.580$ & 0 & & 0 & 0 & 1.00 & 1.00 & Synthetic; pure-Mg clinochlore. & Yoder, 1952, p. 576 \\
\hline 24 & + & 1.581 & .20 & & 3 & 3.4 & 1.50 & 1.51 & Associated with small serpentinite body. & Orcel, 1928 (31) \\
\hline 25 & + & 1.562 & 1.66 & & 0 & 1 & 1.42 & 1.45 & Albite pesnatite in serpentinite. & Orcel, 1928 (32) \\
\hline 26 & + & 1.581 & .24 & .49 & 1 & 1 & 1.49 & 1.49 & Albite pegmitile in serperitinite. & Orcel, 1928 (33) \\
\hline 27 & + & 1.576 & 1.43 & & .6 & 1 & 1.36 & 1.38 & Albite pegmatite in serpentinite. & Orcel, 1928 (34) \\
\hline 28 & + & 1.570 & .45 & .30 & .2 & .5 & 1.44 & 1.44 & Albite pegmatite in serpentinite. & Orcel, 1928 (35) \\
\hline 29 & & 1.593 & .67 & & 7 & 7.6 & 1.34 & 1.36 & With corrundum and spinel. & Orcel, 1928 (57) \\
\hline 30 & + & 1.588 & 1.04 & & 9 & 10 & 1.40 & 1.41 & With corundum and spinel, & Orcel, 1928 (58) \\
\hline 31 & + & 1.587 & 2.56 & & 9.6 & 13 & 1.31 & 1.37 & With corundum and spinel. & Orcel, 1928 (59) \\
\hline 32 & . & 1.594 & 1.45 & & 15.4 & 17.4 & 1.41 & 1.44 & With comundum and spinel. & Orcel, $1928(67)$ \\
\hline 33 & + & 1.593 & .57 & & 17 & 18 & 1.36 & 1.37 & With margarite. & Orcel, $1928(68)$ \\
\hline 34 & + & 1.605 & 2.86 & & 34.6 & 38 & 1.39 & 1.46 & $?$ & Orcel, 1928 (78) \\
\hline 35 & + & 1.616 & 2.00 & & 38 & 40 & 1.24 & 1.29 & $\begin{array}{l}\text { In quartz veins cutting complex of aplite dikes, } \\
\text { amphibolite gneiss and diabase dikes. }\end{array}$ & Orcel, 1928 (95) \\
\hline 36 & - & 1.649 & - & 1.38 & 94 & 94 & 1.47 & 1.47 & $\begin{array}{l}\text { * } \\
\mathrm{K}_{2} \mathrm{O}+\mathrm{Na}_{2} \mathrm{O} \text { in welght percent 1s given where reported } \\
\text { unless the analysis was corrected by the author, in } \\
\text { which case the corrected analysis was used. Where } \\
\text { a chlorite analysis contains much alkali, the sample } \\
\text { probably contained impurities. }\end{array}$ & Orcel, 1928 (132) \\
\hline
\end{tabular}




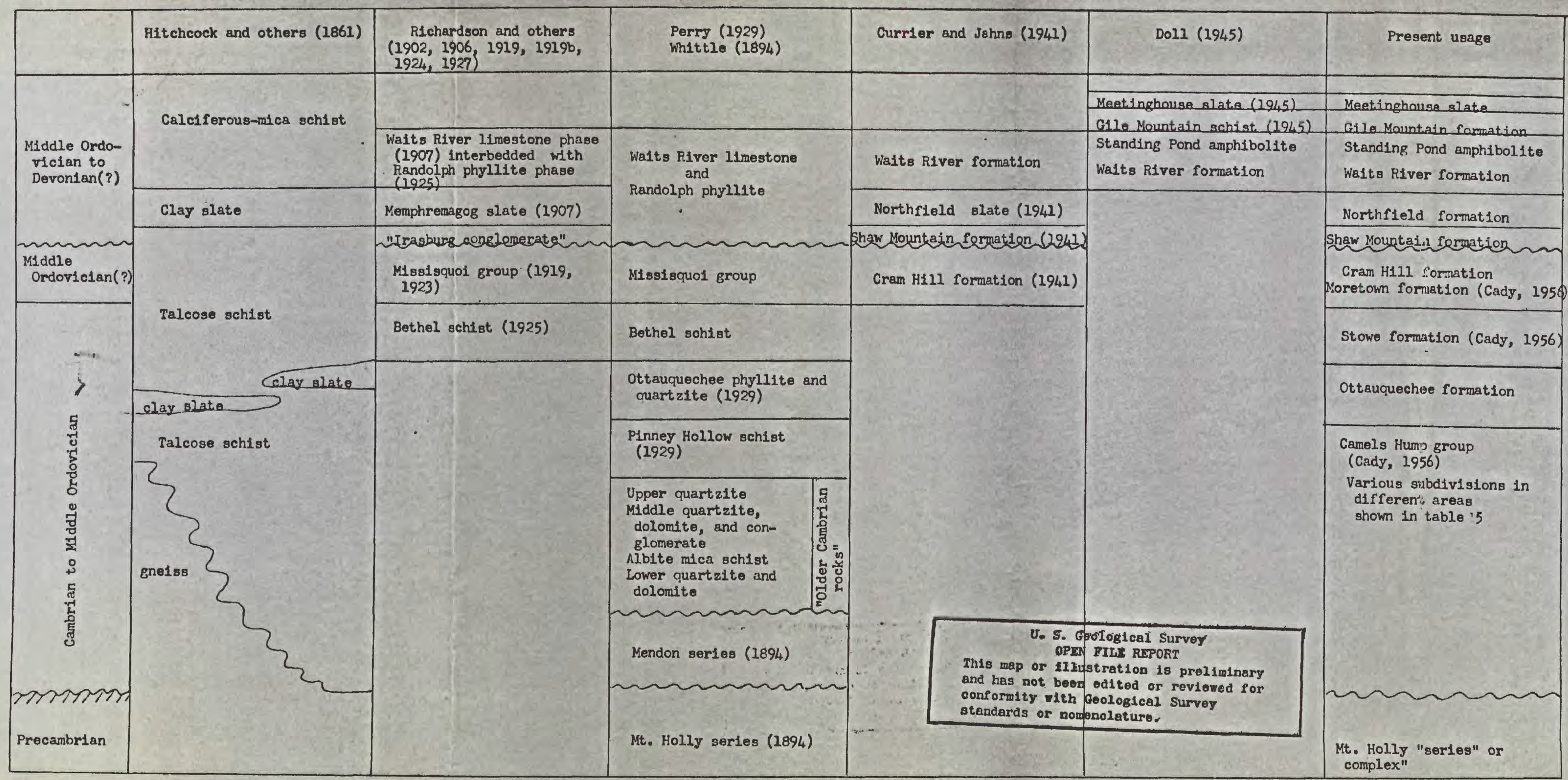

Table 14 Development of the rock unfts of Eastern Vermont sequence. Date in parenthesis after names still in use gives date of introduction. 
